\title{
The Making of a Cold War Air Force: Planning and Professionalism in the Postwar Royal Canadian Air Force, 1944-1950
}

\author{
By \\ Alexander Angus Babcock, B.A, M.A.
}

A Thesis submitted to the

Faculty of Graduate Studies and Research

In partial fulfilment of

The requirements for the degree of

Doctor of Philosophy: History

Department of History

Carleton University

Ottawa, Ontario

December 2008

(C) 2008, Alexander Angus Babcock 


$\begin{array}{ll}\begin{array}{l}\text { Library and } \\ \text { Archives Canada }\end{array} & \begin{array}{l}\text { Bibliothèque et } \\ \text { Archives Canada }\end{array} \\ \begin{array}{l}\text { Published Heritage } \\ \text { Branch }\end{array} & \begin{array}{l}\text { Direction du } \\ \text { Patrimoine de l'édition }\end{array} \\ \begin{array}{l}\text { 395 Wellington Street } \\ \text { Ottawa ON K1A 0N4 } \\ \text { Canada }\end{array} & \begin{array}{l}\text { 395, rue Wellington } \\ \text { Ottawa ON K1A 0N4 } \\ \text { Canada }\end{array}\end{array}$

Your file Votre référence ISBN: 978-0-494-47471-6 Ourfile Notre référence ISBN: 978-0-494-47471-6

NOTICE:

The author has granted a nonexclusive license allowing Library and Archives Canada to reproduce, publish, archive, preserve, conserve, communicate to the public by telecommunication or on the Internet, loan, distribute and sell theses worldwide, for commercial or noncommercial purposes, in microform, paper, electronic and/or any other formats.

The author retains copyright ownership and moral rights in this thesis. Neither the thesis nor substantial extracts from it may be printed or otherwise reproduced without the author's permission.
AVIS:

L'auteur a accordé une licence non exclusive permettant à la Bibliothèque et Archives Canada de reproduire, publier, archiver, sauvegarder, conserver, transmettre au public par télécommunication ou par l'Internet, prêter, distribuer et vendre des thèses partout dans le monde, à des fins commerciales ou autres, sur support microforme, papier, électronique et/ou autres formats.

L'auteur conserve la propriété du droit d'auteur et des droits moraux qui protège cette thèse. $\mathrm{Ni}$ la thèse ni des extraits substantiels de celle-ci ne doivent être imprimés ou autrement reproduits sans son autorisation.
In compliance with the Canadian Privacy Act some supporting forms may have been removed from this thesis.

While these forms may be included in the document page count, their removal does not represent any loss of content from the thesis.
Conformément à la loi canadienne sur la protection de la vie privée, quelques formulaires secondaires ont été enlevés de cette thèse.

Bien que ces formulaires aient inclus dans la pagination, il n'y aura aucun contenu manquant.

\section{Canada}




\begin{abstract}
$\underline{\text { ABSTRACT }}$
This dissertation examines the role of planning and enhanced professionalism played in the growth of the RCAF between postwar demobilization and the assumption of NATO commitments in 1950 . This period represents the nadir and the conditions for the apogee of postwar air force fortunes, in terms of organizational size and capabilities. There were a range of influences on the postwar growth of the RCAF. The Soviet Union posed a threat to North American and European security and the air force was best situated to respond to it. Defence collaboration with the United States fostered development of a vast air defence system. The creation of a NATO Integrated Force led to a large fighter-interceptor contribution from Canada. RCAF leadership was effective in presenting plans to the government and in managing air force interests. Political leaders within Canada in the late 1940s embraced opportunities to engage with the international community and take part in multilateral defence initiatives. Theories of civil-military relations inform assessments of the interaction between the government and the RCAF. The dissertation concludes that all of these influenced, in varying degrees, the nature and degree of success of RCAF, but focuses on the crucial role of planning and professionalism. Improvements to planning processes, procedures and capabilities allowed an increasingly professional RCAF to take advantage of these opportunities, resulting in the creation of a Cold War air force.
\end{abstract}




\section{ACKNOWLEDGEMENTS}

This dissertation was made possible through the support and assistance of many individuals and organizations. Library and Archives Canada staff was consistently helpful in accessing records. Staff at National Defence's Department of History and Heritage deserves special recognition for their willingness to assist researchers. Elsie Lafontaine, Heather Campbell, Nancy Stroud and Laurie McKim at the National Defence Headquarters (NDHQ) Library reliably provided assistance tracking down hard to find books and articles. During my service career, Gord Graham and Paul Poirier allowed me the opportunity to pursue academic upgrading. My current workplace, the Centre for Operational Research and Analysis at NDHQ, provided support and I am grateful to Maria Rey, Jocelyn Tremblay and Paul Massel for the opportunity to complete my thesis. Over the years, Joan White at Carleton University managed to keep me registered and in good standing with the doctoral programme. Her great patience, warmth and kindness are a blessing for all that deal with her. My sister, Janet Weber, provided timely and much needed administrative assistance during the thesis vetting process. I had the good fortune to have two thesis supervisors. Stephen Harris was unstintingly generous with his profound knowledge of the RCAF and military professionalism, and provided friendship and a sounding board for my various ideas on how to proceed. Norman Hillmer gave crucial and timely advice, guidance and support, and was instrumental in saving me from myself. His comprehensive knowledge of Canadian political and defence matters was critical for this dissertation. Lastly, my wife, Susan Babcock, provided constant love, enduring encouragement and continuous support throughout the years, and is responsible for any success that I may achieve, academic or otherwise. 


\section{Table of Contents}

Page

$\begin{array}{lll}\text { Abstract } & \text { ii }\end{array}$

$\begin{array}{ll}\text { Acknowledgements } & \text { iii }\end{array}$

Table of Contents iv

Abbreviations and Acronyms vii

Introduction 1

Chapter One: Visions of a Multi-purpose Air Force: RCAF Postwar Planning 1944-1945

The Post Hostilities Problems Working Committee $\quad 30$

$\begin{array}{ll}\text { Initial RCAF Postwar Planning } & 38\end{array}$

RCAF Post War Organization Proposals $\quad 43$

The Evolving Perception of the Security Environment 57

$\begin{array}{ll}\text { Conclusion } & 63\end{array}$

Chapter Two: "A Very Bitter Stage": Postwar Retrenchment, 1945-1946 66

$\begin{array}{ll}\text { Postwar Government Direction } & 67\end{array}$

Postwar Canadian Security Situation $\quad 76$

Demobilization of the Wartime RCAF

Implementation of Scheme B $\quad 87$

Role of Planning $\quad 95$

Communism and Canada 97

Hope for the Future $\quad 99$

$\begin{array}{lr}\text { Conclusion } & 101\end{array}$

Chapter Three: The Basic Security Plan: Planning for North American Air Defence, 1946-1948

Identifying the Threat

Political Oversight of the Basic Security Plan 113

$\begin{array}{lr}\text { The Military Cooperation Committee } & 123\end{array}$

$\begin{array}{lr}\text { The Basic Security Plan } & 128\end{array}$

Air Defence and Inter-service Rivalry 132

Conclusion

Chapter Four: Rebuilding the RCAF - 1947-1948 145

$\begin{array}{lr}\text { Inter-Service Planning Group } & 146\end{array}$

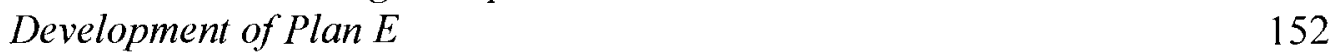


Countering the Threat 162

An Enhanced Planning Capability for the RCAF 165

Policy Statement on Canada's Defence $\quad 171$

Regular and Auxiliary RCAF Shortfalls 174

The Strategic Environment $\quad 180$

New Government Direction $\quad 185$

A New Beginning - Plan F 190

Conclusion 195

Chapter Five: Gaining Influence: The Rise of the RCAF, 1949

Air Defence and Related Plans 203

Prioritization of Air Force Tasks 227

Long Range Plan 229

Changes to the Threat Environment 231

American and NATO Influences on Planning 236

Changes to Canadian Defence Planning 242

Conclusion

Chapter Six: A Revitalized Air Force: RCAF NATO and Air Defence

Planning - 1950

Updated Threat Appreciations 254

Planning in Early 1950

Preliminary Cabinet Defence Committee Direction-1950 261

Korea 268

Short and Medium Term Plans 273

Plan G 280

Planning for the Future $\quad 286$

Conclusion 297

$\begin{array}{ll}\text { Conclusion } & 301\end{array}$

$\begin{array}{ll}\text { Bibliography } & 310\end{array}$

Tables:

Table 1: Postwar Auxiliary Squadron Proposal 45

Table 2: Proposed Aircraft Distribution 55

Table 3: Schemes A, B and C 75

Table 4: Plan B Auxiliary RCAF Proposal 94

Table 5: Plan F Squadron Allocation $\quad 192$

Table 6: Proposed Fighter Squadron and Airfield Disposition (1949) 210

Table 7: Comparison of Peacetime Defence Budgets, 1951-53 248

Table 8: RCAF Requirements - $1950 \quad 262$

Table 9: RCAF Contribution for the CUSRPG Short Term Plan (1950) 274

Table 10: RCAF Medium Term War Plan Requirements (1950) 277

Table 11: Plan G Regular RCAF Operational Aircraft Increases 282 
Figures:

Figure 1: Initial Postwar Command Structure Plan 51

Figure 2: Initial Postwar Plans Organization Proposal 53

Figure 3: Plan B Command Structure 91

Figure 4: Plan E Geographic Command Structure $\quad 154$

Figure 5: Plan F Command Structure $\quad 193$

Figure 6: Air Defence Command Plan 214

Figure 7: Air Defence Control Plan 215 


\section{ABBREVIATIONS AND ACRONYMS}

\begin{tabular}{|c|c|}
\hline AFHQ & Air Force Headquarters \\
\hline CAS & Chief of the Air Staff \\
\hline $\mathrm{CF}$ & Canadian Forces \\
\hline $\mathrm{CSC}$ & Chiefs of Staff Committee \\
\hline CUSRPG & Canada-United States Regional Planning Group \\
\hline GCI & Ground Control Interception \\
\hline DHH & Directorate of History and Heritage \\
\hline DND & Department of National Defence \\
\hline LAC & Library and Archives Canada \\
\hline $\mathrm{MCC}$ & Military Cooperation Committee \\
\hline MG & Manuscript Group \\
\hline $\mathrm{mm}$ & Millimetre \\
\hline MND & Minister of National Defence \\
\hline MPH & Miles per hour \\
\hline NATO & North Atlantic Treaty Organization \\
\hline NDHQ & National Defence Headquarters \\
\hline No. & Number \\
\hline NORAD & North American Air Defence \\
\hline NS & Nova Scotia \\
\hline OR & Operational Requirement \\
\hline PEI & Prince Edward Island \\
\hline PHP & Post-Hostilities Problems \\
\hline PJBD & Permanent Joint Board on Defence \\
\hline PQ & Province of Quebec \\
\hline RAF & Royal Air Force \\
\hline RCAF & Royal Canadian Air Force \\
\hline $\mathrm{RCN}$ & Royal Canadian Navy \\
\hline RG & Record Group \\
\hline US & United States \\
\hline USAF & United States Air Force \\
\hline USSR & Union of Soviet Socialist Republics \\
\hline Vol & Volume \\
\hline
\end{tabular}


W.D.

viii 


\section{Introduction}

The aim of this thesis is to examine how the Royal Canadian Air Force (RCAF) transformed from a Second World War force, largely dedicated to the strategic bombing role, into a cold war entity primarily focused on a fighter-interceptor mandate. This will be achieved through an examination of planning activities by the air force during the period 1944 to 1950 and its enhanced and evolving professionalism. Throughout history, military planning has been an intricate and dynamic process by which an army, navy or air force prepares itself for the future. ${ }^{1}$ RCAF Headquarters staff systematically and extensively collected and analyzed information to prepare plans for the future. ${ }^{2}$ Plans are the means by which the air force identified its role and mission; assessed its need for equipment; conducted operations and training; worked with the other services and government departments; and managed resources. In order for the air force to thrive, planning had to be a pivotal activity.

This thesis will be the first detailed examination covering the period from the beginning of plans to demobilize the wartime RCAF and return to a peacetime force until 1950 , by which time the air force had set the conditions to achieve greater success, in terms of organizational growth and budget share, than its army and navy counterparts. The thesis is one of the first scholarly works devoted to exploring military planning

\footnotetext{
${ }^{1}$ For discussion on the role and nature of military planning, see Henry G. Gole, The Road to RainbowArmy Planning for Global War, 1934-1940 (Annapolis: Naval Institute Press, 2003), Maurice Matloff and Edwin M. Snell, Strategic Planning for Coalition Warfare, 1941-1942, United States Army in World War II: The War Department (Washington: Office of the Chief of Military History, Department of the Army, 1953), and Steven T. Ross, American War Plans, 1941-1945 (London: Frank Cass, 1997).

${ }^{2}$ Dallas D. Irvine, "The Origin of Capital Staffs", The Journal of Modern History, Vol X, No. 2, June 1938, p. 165 describes planning processes generically, not for RCAF Headquarters specifically.
} 
activities within Canada. ${ }^{3}$ It will also explore the growing professionalism ${ }^{4}$ within the air force and how this affected civil-military relations between the RCAF and the government. $^{5}$

Certainly the immediate postwar period at first held little promise for the air force, as demobilization reduced it to a mere shell of its former strength. In fact, by early 1947, the RCAF had no aircraft on strength suitable for either an offensive or defensive combat role; its inventory of aircraft had been reduced from a Second World War force capable of conducting large scale bombing, fighter and combat support missions to one devoid of the ability to take on anything but simple transport, training and surveying roles. However, for a range of national, international, political and economic reasons, soon afterwards the Canadian public and political leaders came to support the strategic aims and plans of the air force. As a result, by the beginning of the 1950s, the RCAF expanded to a sizeable and capable force.

This increased size and status of the RCAF was brought about by a number of external factors, including the emerging Soviet threat, technological advances related to weaponry and aircraft, and the creation of defensive partnerships, first individually with

\footnotetext{
${ }^{3}$ Bryan Brulotte, "Visions of Grandeur: Planning for the Canadian Post-war Army, 1944-1947", an unpublished MA thesis in History, Carleton University, Ottawa, 1991, is one of the few such efforts in this field.

${ }^{4}$ For the purposes of this thesis, the process of professionalization is two-fold. In the first place, it refers to "the process by which individuals are being transformed from a state of relative unawareness of the theoretical and practical problems of the profession's issue area, to the state of acute awareness of such problems." Secondly, it refers "to the historical transformations of a particular occupational group, under the impact of major political, economical and technological developments." While the first definition relates to the qualifications and capabilities accrued by air force personnel in the conduct of their duties, the second pertains to developments and influence associated with the RCAF as an organization. For further details on this approach to professionalism, see Bengt Abrahamsson, Military Professionalization and Political Power (Beverly Hills: Sage Publications, 1972), p. 16.

${ }^{5}$ There is a small body of work related to Canadian civil-military relations and professionalism with the Canadian military, such as Desmond Morton, Ministers and Generals: Politics and the Canadian Militia, 1868 - 1904 (Toronto: University of Toronto Press, 1970) and Stephen Harris,. Canadian Brass - The Making of a Professional Army, 1860-1939 (Toronto: University of Toronto Press, 1988).
} 
the United States and then multilaterally with the western democracies through creation of the North Atlantic Treaty Organization (NATO). However, none of these external variables demanded that the air force develop in the way that it did. Rather, far from being inevitable, that growth was facilitated by a number of reasons internal to the RCAF, including the aptitudes and abilities of several key air force leaders and the enhanced skill developed over time in preparing and submitting plans. The air force's ability to successfully compete with the other services for a larger share of the defence budget hinged on these plans, which described how Canada ought to respond to the evolving threat.

A change in Canadian political leadership, from William Lyon Mackenzie King to Louis St. Laurent, was a further important contributor to the change in air force fortunes. Mackenzie King often did not support the idea of spending large sums of money on the military, as demonstrated by James Eayrs" contention that "[d]efence policy was from the outset distasteful to Mackenzie King, and for reasons as much personal as political" and that "no prime minister could have been more eager to find excuses for curtaining expenditure upon defence". 6 King stated desire was to "get back to the old Liberal

\footnotetext{
${ }^{6}$ James Eayrs, In Defence of Canada: From the Great War to the Great Depression (Toronto: University of Toronto Press, 1967, pp. 168-9. Despite these comments about King's tendency to avoid military spending, Roger Sarty, in "Mr. King and the Armed Forces", Norman Hillmer et al, eds, A Country of Limitations: Canada and the World in 1939, (n.p.: Canadian Committee for the History of the Second World War, 1996), pp. 217-246, describes the circumstances surrounding King's injection of funds into the military, and especially the air force, in the immediate pre-war period. With the rise in European tensions following the Munich Crisis and the German invasion of Czechoslovakia, King supported additional defence expenditures for enhanced naval and air force coastal defence capabilities, and for an aircrew training program. In addition to improving Canadian security, the coastal defence measures were intended to bolster Canadian sovereignty. American president Franklin Roosevelt had confirmed to King the intention to use American forces to secure the British Columbia coast from use by the Japanese should Canada fail to do so (p. 220). The aircrew training program was designed to provide a major contribution to the war effort in place of an army expeditionary force, thereby avoiding the kind of battlefield casualties experienced in the First World War (p. 239). These initiatives may have been, as argued by Sarty, "bold initiates in military policy" by King, but they were also moderated by "politically-motivated restraints he placed on military expansion ... [that] flew in the face of his own military objectives" (p. 217).
} 
principles of economy, reduction of taxation, anti-militarism". ${ }^{7}$ Historian David

Bercuson noted that Mackenzie King's post-Second World War government "was firmly

committed to drastic cuts in the defence budget to free up funds for family allowances, veteran's benefits, and other new social programs". ${ }^{8}$ St. Laurent, on the other hand, tended to look to the future and to proactively address security and defence matters before they became national issues. Early on he supported the establishment of the North Atlantic Treaty Organization (NATO) to counter the Soviet threat, and asked Canadians during a November 1948 radio broadcast to support the treaty as a practical approach to national security. Comparing participation in the treaty to the need for household fire insurance, he argued that participating in it would be "far, far less costly than the losses we would face if a new conflagration devastated the world". 9 The RCAF was to benefit from this more positive approach to national defence matters.

The thesis will take into account strategic, political and technological developments as they pertain to RCAF planning activities, as well as the repercussions of

The government can finance the military in two ways: steady-state or surge. With steady-state funding, the military is provided sufficient capital to obtain equipment and the time to develop the skill and experience needed to effectively use it. With surge funding, which was provided by King in 1939 , equipment may be purchased on short notice, but the military has little time to develop the professional skills needed to achieve a reasonable level of combat effectiveness. Therefore, while King's willingness to inject cash to the military during time of crisis needs to be acknowledged, Eayrs' overall contention that King was not supportive of the profession of arms remains valid.

For more complete details on the government's attempt to prevent the commitment of ground forces during the Second World War by emphasizing aircrew training, see Sandy Babcock, "The British Commonwealth Air Training Plan and Limited Liability" in William March and Robert Thompson, eds, The Evolution of Air Power in Canada: 1916 to the Present Day (n.p.: Department of National Defence, 1997).

${ }^{7}$ James Eayrs, In Defence of Canada - Peacemaking and Deterrence (Toronto: University of Toronto Press, 1972), p. 92.

${ }^{8}$ David Jay Bercuson, True Patriot - The Life of Brooke Claxton, 1898-1960 (Toronto: University of Toronto Press, 1993, p. 154. C.P. Stacey, Canada and the Age of Conflict, Volume 2 (Toronto: University of Toronto Press, 1984), pp. 404-405, provides discussion on the economic problems encountered postwar because of credit shortages in Europe and a Canadian trade imbalance with the United States. J. Douglas Gibson, ed., Canada's Economy in a Changing World (Toronto: Macmillan, 1948) provides a period description of the anxiety over the postwar economy within Canada. 
air force efforts to take on roles independent of the other armed services. A significant development soon after the end of the war was the production of regular intelligence assessments of potential enemy capabilities and intentions, which provided much of the justification for the growth experienced by the air force during the late 1940s and early 1950s. Many of these assessments have recently been declassified by Library and Archives Canada (LAC) and will be examined for their influence upon the development of defence plans and the changing relationship between the armed services.

The RCAF emerged from the Second World War uncertain of its future but determined to avoid the dismemberment its predecessor had suffered in the years immediately following the Great War. Planners at Air Force Headquarters had assumed, or at least had hoped, that the postwar RCAF would remain balanced and would retain a respectable number of the nearly seventy active service squadrons established at home and abroad between 1939-1945. After all, many of these RCAF officers had participated in high-level planning in the war against Germany and were accustomed to large-scale operations. Their experience in No. 6 (RCAF) Bomber Group and in No. 83 (Composite) Group had prepared them for much more than the civil government air operations that had been a major portion of the RCAF duties during much of the 1920s and 1930s. It is unlikely that they would have derived much satisfaction from reverting to their role as "bush pilots in uniform.",10

\footnotetext{
${ }^{9}$ J.W. Pickersgill, My Years with Louis St. Laurent - A Political Memoir (Toronto: University of Toronto Press, 1973), p. 86.

${ }^{10}$ This description was provided by Air Vice Marshal T.A. Lawrence concerning the effect of civil government air operations, which largely consisted of mapping and charting parts of Canada from the air, on pre-World War II RCAF pilots. W.A.B. Douglas, The Creation of a National Air Force - The Official History of the Royal Canadian Air Force, Volume II (Toronto: University of Toronto Press, 1986), p. 91, refers.
} 
These aspirations may be glimpsed in the air force's internal preparations for Tiger Force, the air component for a protracted war against Japan after the fall of Europe, which, having been severely curtailed already by the government, were rendered unnecessary by the atomic bombing of Hiroshima. Less dramatically, these hopes were also visible in the RCAF's contribution to the government's Post-Hostilities Planning process, which was an interdepartmental effort to predict the nature of the postwar world and the armed forces Canada would require in it. Despite RCAF efforts to the contrary, between the initial meetings of 1944 and the ending of the war in August 1945, the forecast size of the postwar RCAF shrank perceptibly. Moreover, with the American introduction of atomic weapons, the Canadian government decided to forego any strategic bombing role for the RCAF, relying instead upon the Americans for this purpose. ${ }^{11}$ As a result, one of the major wartime roles for the air force was denied it after the war.

These decisions were not made naively or in the absence of information. That one day the Soviet Union might become a potential adversary was commonly perceived $^{12}$; however, many Canadian politicians, and certainly Prime Minister Mackenzie King ${ }^{13}$, believed that there was nothing inevitable or necessary about this.

\footnotetext{
${ }^{11}$ See, for example, James Eayrs, In Defence of Canada - Growing Up Allied (Toronto: University of Toronto Press, 1980), p. 234, and Tom Keating and Larry Pratt, Canada, NATO and the Bomb-The Western Alliance in Crisis (Edmonton: Hurtig Publishers, 1988), pp. 1-5.

12 For instance, refer to LAC, Record Group 24, Vol 6170, File HQ 15-48-2A, C.P.H.P. (44) Report 2 (Final), entitled "Advantages and disadvantages of the regional organization of security and defense [sic]", [April 1944], L.B. Pearson, "Canada Looks North", Foreign Affairs, Vol 24, No. 4 (July 1946, 628-637), various intelligence appreciations, including Department of National Defence, Directorate of History and Heritage (DHH) 193.009 (D 53), Box 2, Papers and Meetings, Chiefs of Staff Committee, Vol 66, May 1947, J.I.C. 1 (Final), report entitled "Joint Intelligence Committee - Strategic Appreciation", dated 15 March 1947, and numerous RCAF Plans, including DND, DHH 181.004 (D45), RCAF Plan "E" 1948-49 for examples of Canadian concern about the potential threat posed by the Soviet Union..

${ }^{13}$ LAC, RG 24, Vol 6172, file 15-48-12, Minutes of the Sixth Meeting of the Advisory Committee on Post Hostilities Problems held on Friday, January $12^{\text {th }}$, in Room 123 in the East Block, dated $12^{\text {th }}$ January 1944,
} 
Accordingly, at least one element in deliberations about the future size of the armed forces in late 1945 was exactly the same as had existed after 11 November 1918:

"Defence against whom" was an obvious question and a precipitous downsizing of the armed forces appeared warranted and logical.

The immediate postwar fiscal cutbacks, which undermined the post-hostilities planning assumption that there would be a large peacetime air force, provided challenges for RCAF leaders and planners. This situation was aggravated by the changing technological environment, as advances in aircraft design, avionics, propulsion systems and weaponry led to demands for more sophisticated and capable aircraft. The government and the RCAF were to struggle with the challenges of adopting and integrating this new and expensive technology.

As the postwar alignment of the western allies against the Soviet Union became apparent, Canadian defence arrangements changed. The threat to Canada seemed to grow, as the government, the military and the public increasingly viewed the Soviet Union as a possible danger to national security. ${ }^{14}$ As a consequence of this shifting geopolitical environment, the early postwar trend towards fiscal retrenchment was reversed after a series of developments, including the early Cold War, Korean Conflict, and NATO and North American air defence commitments. These led to a massive

provides an example of King advocating peaceful negotiations instead of Canadian participation in a defensive alliance as a means of dealing with a perceived threat from the Soviet Union.

${ }^{14}$ See, for example, Colin Gray, Canadian Defence Priorities: A Question of Relevance (Toronto: Clarke Irwin, 1972), Joseph Jockel, No Boundaries Upstairs: Canada, the United States and the Origins of North American Air Defence, 1945-1958 (Vancouver, UBC Press, 1987), Reg Whitaker and Gary Marcuse, Cold War Canada: The Making of a National Insecurity State, 1945-1957 (Toronto: University of Toronto Press, 1994), Melvin Conant, The Long Polar Watch: Canada and the Defense of North America (New York: Harper, 1962), L.B. Pearson, "Canada Looks North", Foreign Affairs, Vol 24, No. 4 (July 1946, 628-637) and "Canada's Northern Horizon", Foreign Affairs, Vol 31, No. 4 (July 1953). 
organizational expansion for the RCAF that began in the late 1940s and continued into the next decade.

Air force plans, policy and doctrine underwent a series of changes and refinements in the postwar years as it took on new roles and RCAF leadership had to deal with the challenges of building and deploying a combat capable air force across a wide geographic area. Beginning in 1947, an air interception role was identified and developed for home defence, with a series of bases and radar sites built across the country over a period of more than a decade. In 1950, the groundwork was completed for a NATO Integrated Force through the establishment of an air division of 12 squadrons in Europe, which for a time was larger than any fielded by the European NATO members. The Integrated Force was designed as part of the western democracies' response to the evolving Cold War and speaks to why the RCAF during this period should be viewed as a Cold War air force.

Concurrent with these developments, RCAF commitment to the tactical support role to the army waned markedly. This task, referred to as close air support, involved air attacks against enemy forces located near friendly troops and necessitated complex coordination of air assets with friendly ground forces in order to avoid casualties to one's own troops. It required the RCAF to be subordinate to Canadian Army needs and direction, contrary to the air force's goal of a more prominent defence role and control of its own destiny. The fighter-interceptor role held more promise for the air force, since it was a function for which it had sole responsibility. This RCAF pursuit of an independent role contributed to the inter-service rivalry between the army and air force. 
The RCAF quest for enhanced and independent postwar status was also a factor in its relationship with its reserve force (the RCAF Auxiliary). After initially allocating domestic air defence to the Auxiliary force, the RCAF soon moved this important, high profile role to the fulltime force. The Auxiliary's difficulty in achieving and maintaining a sufficiently high standard of training and operational preparedness also contributed to this decision.

There are few scholarly works examining the postwar RCAF and none that concentrate on the planning activities of the RCAF. The Official Histories of the RCAF (Volumes 1-III) cover from the First World War participation of Canadians with the Royal Air Force, to the 1924 creation of the RCAF and until the end of the Second World War. Widely available histories such as Leslie Roberts' There Shall Be Wings: A History of the Royal Canadian Air Force provide limited postwar details ${ }^{15}$. Larry Milberry's Sixty Years: The RCAF and CF Air Command, 1924-1984, provides a picturesque survey of the evolution of the RCAF with a main focus on personnel and aircraft, but does not provide any significant analysis or insights into plans, policy and doctrine. ${ }^{16}$ This absence of scholarly work continues after the period covered by this thesis. Issues such as the establishment of North American Air Defence (NORAD) ${ }^{17}$, Canadian involvement in the Cuban Missile Crisis ${ }^{18}$ and the addition of nuclear weapons

\footnotetext{
${ }^{15}$ Leslie Roberts, There Shall Be Wings: A History of the Royal Canadian Air Force (Toronto: Clarke, Irwin \& Company, 1959).

${ }^{16}$ Larry Milberry, ed. Sixty Years: The RCAF and CF Air Command, 1924-1984 (Toronto: CANAV Books, 1984).

${ }^{17}$ Joseph Jockel, op. cit, and Canada in NORAD, 1957-2007: A History (Montreal: Queen's University Press, 2007).

${ }^{18}$ Peter T. Haydon, The 1962 Cuban Missile Crisis: Canadian Involvement Reconsidered (Toronto: Canadian Institute of Strategic Studies, 1993).
} 
in the Canadian arsenal ${ }^{19}$ have been examined in isolation, but the effect of these events upon the RCAF at the strategic, policy and doctrinal levels remains essentially unexamined.

A number of more general political and military histories dealing with the 19451950 period have emphasized a special Canadian relationship with the United States, and the way in which this influenced government decision making in the defence field. This approach held that the conspicuous Soviet threat to North America, combined with American interest in establishing a joint system of continental air defence, led to decisions by the government that emphasized a cooperative approach to defence. Related to this, and largely unexplored, is analysis of how this contributed to an enhanced defence role for the RCAF and whether this affected air force plans, policy, doctrine and organization. Examples of this cooperative approach to defence include James Eayrs' In Defence of Canada - Growing Up Allied ${ }^{20}$, Jon McLin's Canada's Changing Defense Policy, 1957-1963: The Problems of a Middle Power in Alliance ${ }^{21}$, and Melvin Conant's Long Polar Watch-Canada and the Defense of North America. ${ }^{22}$

These earlier approaches are incomplete. As demonstrated in C.P. Stacey's Canada and the Age of Conflict ${ }^{23}$ and R.D. Cuff and J.L. Granatstein's Canadian-

\footnotetext{
${ }^{19}$ John Clearwater, Canadian Nuclear Weapons: The Untold Story of Canada's Cold War Arsenal (Toronto: Dundurn Press, 1998). Related to this was the presence of American nuclear weapons on Canadian Soil, the story of which is told in John Clearwater, U.S. Nuclear Weapons in Canada (Toronto: Dundurn Press, 1999).

${ }^{20}$ James Eayrs, In Defence of Canada - Growing Up Allied (Toronto: University of Toronto Press, 1985).

${ }^{21}$ Jon B. McLin, Canada's Changing Defense Policy, 1957-1963: The Problems of a Middle Power in Alliance (Baltimore, MD: Johns Hopkins Press, 1967).

${ }^{22}$ Melvin Conant, The Long Polar Watch: Canada and the Defense of North America, (New York: Harper, 1962).

${ }^{23}$ C.P. Stacey, Canada and the Age of Conflict, Volume 2: 1921-1948, The Mackenzie King Era (Toronto: University of Toronto Press, 1986), pp. 360-362 and 406-407.
} 
American Relations in Wartime: From the Great War to the Cold War, ${ }^{24}$ Canada often resisted American efforts to do more in the area of North American defence during and after the Second World War. ${ }^{25}$ While these works have contributed to our understanding of defence issues in the postwar era, they provide little insight into the role of the RCAF as a separate actor within the wider context of national defence. But it was also true that at times Canada succumbed to American pressures for a larger defence commitment. This thesis will provide a prime example of this in 1950 .

American historiography has long seen the United States Air Force (USAF) as a major contributor to defence policy decision-making. A number of memoirs and biographies, including General Henry H. Arnold's Global Mission ${ }^{26}$, General Curtis E. LeMay's and MacKinley Kantor's Mission with LeMay ${ }^{27}$, and David R. Mets' Master of Airpower-General Carl A Spaatz ${ }^{28}$ discuss the struggle to establish an independent air force in the period leading up to 1947. USAF policy, doctrine and organizational developments have been documented in such works as Walton S. Moody's Building $a$ Strategic Air Force ${ }^{29}$ and Frank Futrell's Ideas, Concepts, Doctrine: A History of Basic Thinking in the United States Air Force, 1907-1964 ${ }^{30}$. A more recent scholarly trend has been research into the nature of the relationship between the USAF and American society and how this affected defence plans and decision-making. Michael Sherry, in The Rise of

${ }^{24}$ R.D. Cuff and J.L. Granatstein, Canadian-American Relations in Wartime: From the Great War to the Cold War (Toronto: Hakkert, 1975).

${ }^{25}$ A primary source demonstrating Canadian reluctance and, at times, refusal to participate in ambitious and costly American defence plans during the 1946-1951 period is the Chiefs of Staff Committee Meeting Minutes held at the Department of National Defence's Directorate of History and Heritage (DHH).

${ }^{26}$ General Henry H. Arnold, Global Mission (New York: Harper, 1949).

${ }^{27}$ General Curtis E. LeMay and MacKinley Kantor, Mission with LeMay (Garden City, NY: Doubleday, 1965).

${ }^{28}$ David R. Mets, Master of Airpower - General Carl A Spaatz (Novato, California: Presidio Press, 1997).

${ }^{29}$ Walton S. Moody, Building a Strategic Air Force (Air Force History and Museum Program, 1995). 
American Air Power: The Creation of Armageddon", examined the role of "airmindedness" in the development of a special relationship between the USAF and broader American society. Sherry found the air force and American society united in the belief that emerging technologies should be developed for military applications ${ }^{32}$. Steven Call's A People's Airforce: Air Power and American Popular Culture, $1945-1965^{33}$ provided a closer examination of the cultural basis of USAF-societal ties. Call argued that, while American society in the immediate post-Second World War period had faith in the USAF's technological orientation to policy and doctrine issues, technology-based solutions such as massive retaliation were increasingly questioned by the American public by the end of the 1950 s, leading to a more guarded USAF-societal relationship. No similar body of work examining the RCAF's role in defence policy decision-making exists in Canada. ${ }^{34}$

Another historiographic theme examined little in Canada is the impact of professionalization on the armed forces. Amongst western democracies, there are two main and competing schools of thought on the role of professionalization for civil-

\footnotetext{
${ }^{30}$ Frank Futrell, Ideas, Concepts, Doctrine: A History of Basic Thinking in the United States Air Force, 1907-1964 (Maxwell AFB, Alabama: Air University Press, 1965).

${ }^{31}$ Michael S. Sherry, The Rise of American Air Power: The Creation of Armageddon (New Haven: Yale University Press, 1987).

32 "Air-mindedness", which relates to a public and political awareness of and support for the civil and military projection of national goals through air power, is discussed in a range of works, including Joseph J. Corn, The Winged Gospel: America's Romance with Aviation, 1900-1950 (New York: Oxford University Press, 1983), Peter Fritzche, ““"Air Conditioning” Germany," Military History Quarterly, Vol 8, No. 3, 2627, Martin van Crevald, "The Rise and Fall of Air Power," Military History Quarterly, Spring 1996, 76-81, and Peter Fritzsche, A Nation of Fliers: German Aviation and the Popular Imagination (Cambridge: Harvard University Press, 1992).

${ }^{33}$ Steven Charles Call, unpublished History PhD thesis "A People's Airforce: Air Power and American Popular Culture, 1945-1965", The Ohio State University, 1997.

${ }^{34}$ The role of the RCAF in defence decision-making is outside the scope of this thesis, but a study into this area would be worthwhile.
} 
military relations, headed by Americans Samuel Huntington and Morris Janowitz ${ }^{35}$ respectively. In The Soldier and the State: The Theory and Politics of Civil-Military Relations, Huntington, a political scientist, defined professionalism as comprising the characteristics of expertise, responsibility and corporateness. Expertise refers to specialized knowledge and skill in a specific field based upon education and experience. Responsibility relates to the obligation of professionals to exercise their skills when required by and on behalf of society. Corporateness pertains to the organic unity and consciousness that members of a group have about themselves as part of a profession. Within the context of civil-military relations, Huntington argued that professional soldiers were honour bound to provide their expert advice to politicians and then to act upon the political direction provided, regardless of whether the military was in agreement. To do less would constitute unprofessional behaviour. ${ }^{36}$ Huntington's approach should be viewed as prescriptive, in that it provides an idealised vision of the military within western democracies that is totally apolitical - it fails to deal with the possibility that military forces and commanders have vested interests in defining and promoting defence issues.

Janowitz, a sociologist, examines military professionalism by focusing on such elements as social origins, career lines, social status and prestige, career motivations, self-

\footnotetext{
${ }^{35}$ For discussion about these two schools of thought, see James Burk, "Expertise, Jurisdiction, and Legitimacy of the Military Profession", pp. 19-38 in Lloyd J. Matthews, ed., The Future of the Army Profession (Boston: McGraw-Hill, 2002). Burk questioned whether the 40-year-old Huntington and Janowitz models of military professionalism still applied. He argued that the military professional had progressed from the "management of violence" in the early $20^{\text {th }}$ century to the "management of defence" in the post-Second World War, and finally to the "management of peace" after the Cold War. As a consequence, as the military profession becomes closer aligned with civilian counterparts, there was a requirement to change the way in which the military profession was viewed. Burk, pp. 19-20 refers. For the purposes of this thesis, with its focus on the six year period following the Second World War, these observations add nothing of value.
} 
conceptions and ideology. ${ }^{37}$ Concerning the relationship between military professionalism and civil-military relations, Janowitz and his disciple Bengt Abrahamsson ${ }^{38}$ argue persuasively that the process of professionalization has led to the ability of the military to function capably as an interest group and to compete effectively for resources in the political arena. This view of the military as an interest group places a greater emphasis on what Huntington described as "corporateness", with Janowitz characterizing professional groups such as the military as having developed "a sense of group identity and a system of internal administration. Self-administration ... implies the growth of a body of ethics and standards of performance." ${ }^{39}$ This viewpoint was promoted by Canadian political scientist R.B. Byers, who argued that such corporateness was essential to the profession of arms within Canada, noting that the Canadian military was not integrated with the wider society and instead identified itself as a distinct social group. ${ }^{40}$ Adrian Preston, a historian at the Royal Military College of Canada, expressed similar concerns, indicating in 1971 that the expansion of the officer corps beginning in the early 1950s as the result of defence commitments in Asia, Europe and North America "gave the armed profession a disproportionate and decisive influence in the shaping of national policy that was not seriously contested until the late fifties and sixties". ${ }^{41}$ One of the questions to be answered by this thesis is whether, by developing increasingly

\footnotetext{
${ }^{36}$ Samuel Huntington, The Soldier and the State: The Theory and Politics of Civil-Military Relations (Cambridge, Massachusetts: Belknap Press, 1957), pp. 7-18.

${ }^{37}$ Morris Janowitz, The Professional Soldier: A Social and Political Portrait (New York: Free Press, 1964), p. 7.

${ }^{38}$ Bengt Abrahamsson, Military Professionalization and Political Power (Beverly Hills: Sage Publications, 1972).

${ }^{39}$ Ibid., p. 6

${ }^{40}$ R.B. Byers, "The Nature of Military Professionalism", p. 12, in R.B. Byers and Colin S. Gray, editors, Canadian Military Professionalism: The Search for Identity, Wellesley Paper 2 (February 1973), Canadian Institute of International Affairs. Preston use of "disproportionate" suggests that he was aligned with Huntington's viewpoint.
} 
professional attributes, the RCAF in the late 1940s and early 1950s was able to influence defence policy decisions made by the government.

There is a degree of circular logic about how military professionalism is viewed in the Huntington model: the main argument presented in The Soldier and the State regarding military professionalism can be reduced to the questionable line of reasoning that the military is professional because it behaves professionally. Notwithstanding this, Huntington remains the preferred theorist for various western armed forces, in part because of the basically uncritical description he provides of modern western military attributes and his harmonious depiction of civil-military relations. Certainly, Huntington is the main civil-military theorist taught at the various Canadian military staff schools and colleges. $^{42}$

These same military learning establishments largely ignore Janowitz and Abrahamsson, who portray the professional military as being influenced by self-interests instead of the idealism suggested by Huntington. Another reason for Janowitz not being taught in many military institutions may be a lack of understanding of his view of the military. He advocated that the military be employed as a "constabulary" force, which can easily be misinterpreted as a suggestion that the military should be reduced to a policing function. Yet Janowitz was simply arguing that the military had to consider a wide range of political-social roles, beyond the traditional narrow military focus, and be

\footnotetext{
${ }^{41}$ Adrian Preston, "The Profession of Arms in Postwar Canada, 1945-1970, World Politics, Vol XXIII, No. 2, January 1971, p. 200.

${ }^{42}$ For instance, at the Canadian Forces Staff School, which prepared junior officers for more senior appointments, Huntington's view of civil-military relations was the sole theory discussed in that field in the early 1990s.
} 
capable of contributing to political goals in non-battlefield situations. ${ }^{43}$ The merit of this theory has been borne out by NATO, which recognized in 2007 the requirement for a "comprehensive approach". ${ }^{44}$ For NATO, military victory is no longer seen as resulting only from applying force; it involves shaping events and effects to best advantage and can involve political, economic and social actions. ${ }^{45}$

A critical difference between Huntington and Janowitz is their view of how the military should deal with politics and politicians. For the former, the military should be apolitical. In this view, the military offers advice to political leadership and then faithfully follows any government decisions without challenge. The military's role is to concentrate on acquiring and enhancing military skills, which were used exclusively to support the nation. For Huntington, social and political matters provide contextual considerations for military decision-making but do not determine how a military operation should be conducted. ${ }^{46}$ This idea is captured in what has been described as the American way of war, ${ }^{47}$ which emphasizes total war and unconditional surrender.

Janowitz, on the other hand, has argued that the military had to develop "politicalsocial insights to deal with political-military issues and the ambiguous nature of the security environment." ${ }^{, 48} \mathrm{He}$ believed that there was an absolutist-pragmatist divide

\footnotetext{
${ }^{43}$ Sam C. Sarkesian, "Two Concepts of Military Professionalism", in Michel Louis Martin and Ellen Stern McCrate, eds., The Military, Militarism and the Polity - Essays in Honor of Morris Janowitz (New York: Free Press, 1984), p. 159.

${ }^{44}$ Jaap de Hoop Scheffer, NATO Secretary General, Keynote Address, "NATO and the EU: Time for a New Chapter", Berlin, Germany, 29 January 2007, www.europarl.europa.eu/meetdocs/2004_2009/ documents/dv/280/280220/28022007speechsecrgl_berlin29012007_en.pdf .

${ }^{45}$ An example of a comprehensive approach is when economic sanctions are used to pressure a regime into complying with international policies. For more on this theory, see Edward A. Smith, Complexity,

Networking and Effects-Based Approaches to Operations (Washington: Command and Control Research Program, 2006).

${ }^{46}$ Sarkesian, op. cit., pp. 156-161.

${ }^{47}$ For more details on this theory, see Russell Frank Weigley, The American Way of War - A History of United States Military Strategy and Policy (Bloomington: Indiana University Press, 1977).

${ }^{48}$ Sarkesian, op. cit., p. 156.
} 
within the military. The absolutist viewpoint is one that supports total war and the use of whatever means necessary to achieve it. ${ }^{49}$ Douglas MacArthur's desire to use nuclear weapons in Korea is an example of this. Janowitz preferred a pragmatic method, which considered adapting military means in order to achieve political ends. ${ }^{50}$ From this perspective, total war is not the only recourse; limited war is a viable military option. German military theorist Carl von Clausewitz said the same thing in 1827, with his often misunderstood statement that war was the "continuation of politics by other means". 51 However, the effect of such a pragmatic approach was that it complicated how military force could be used because of political considerations. ${ }^{52}$ This restriction on how war should be conducted required the military to achieve an understanding of political goals. Janowitz's interpretation was that the military professional could not be apolitical.

Another aspect of Janowitz's theory of military professionalism relevant to this thesis is his view of the interrelationship between technical innovation and organizational changes. He indicated that the "uncertainties of war plus the technological environment of the profession has led, since the turn of the century, to a persistent drive toward 'scientific' management. ${ }^{.53}$ The advent of atomic weapons and the changing role of military force in international diplomacy caused this trend to continue, as the importance of "rational and scientific procedures" intensified. ${ }^{54}$ Since this thesis will argue that

\footnotetext{
${ }^{49}$ Morris Janowitz, The Professional Soldier: A Social and Political Portrait (New York: Free Press, 1964), pp. 264-265.

${ }^{50}$ Ibid.

${ }^{51}$ See, for example, Antulio J. Echevarria II, "War, Politics and RMA: The Legacy of Clausewitz", Joint Force Quarterly, Winter 1995-96, pp. 76-80. The misunderstanding is the interpretation that war follows diplomacy as a distinct event. For Clausewitz, war was conducted for political reasons. Once political goals are achieved, there is no reason for the continuation of a conflict.

${ }_{53}^{52}$ Sarkesian, op. cit., p. 166.

${ }^{53}$ Morris Janowitz, "Organizing Multiple Goals: War Making and Arms Control", in Morris Janowitz, ed., The New Military - Changing Patterns of Organization (New York: Russell Sage Foundation, 1964) p. 17. ${ }^{54}$ Ibid., p. 18.
} 
Canadian military history needs to consider the motivation and organizational issues behind some military policies and planning activities, the Janowitz model of civilmilitary relations will be more influential and relevant to this work than the Huntington model. Canadian civil-military relations are not the direct focus of this thesis, but will provide the context for the development of professional attributes within the air force.

Stephen Harris' Canadian Brass - The Making of a Professional Army, 1860$1939^{55}$ is the most substantive Canadian scholarly work in the civil-military relations field. Harris chronicles the struggle by senior Canadian army officers for recognition of a specialized body of knowledge that needed to be considered in the development of defence policy and the organization of the army. He also showed how, following an extended period of political interference in the leadership and conduct of military operations, the acquisition of professional attributes by Canadian soldiers was critical to the development of effective fighting skills. In presenting this argument, Canadian Brass essentially follows the Huntington paradigm of civil-military relations. This thesis is intended to provide a competing view.

Another Canadian work in this field is Desmond Morton's Ministers and Generals - Politics and the Canadian Militia, 1868-190456, which explores the difficult relationship between the professional British officers assigned to Canada in the postConfederation period and the Canadian politicians and soldiers they encountered. While this work provides significant insights into the politics and personalities of the time, it does not focus significantly on the development of professionalism within the Canadian

\footnotetext{
${ }^{55}$ Stephen Harris, Canadian Brass - The Making of a Professional Army, 1860-1939 (Toronto: University of Toronto Press, 1988).

${ }^{56}$ Desmond Morton. Ministers and Generals: Politics and the Canadian Militia, 1868 - 1904 (Toronto: University of Toronto Press, 1970)
} 
military. Similarly, Morton's A Particular Kind of Politics: Canada's Overseas Ministry in the First World War provides valuable details on the political and administrative management of the Canadian war effort from London during the First World War, ${ }^{57}$ especially in relation to the political intriguing of defence minister Sam Hughes. However, this work does not explore the development of professionalism within the Canadian military.

Later scholarship from within the defence community continued in this vein. A review of the 1959 RCAF Staff College Journal provides an example of the tendency of the Canadian military to view itself in terms of the Huntington model. A number of articles, including John Gellner's "Some Thoughts on the Relationship of National Policies and Armed Forces" and "The Discussion and Formulation of National Security Policy" by Richard A. Preston, ${ }^{58}$ represent the Canadian military as a passive participant in defence policy formation. However, this thesis contends that this paradigm does not reflect reality. It will argue that RCAF planning was influenced, in the Janowitzian model, by organizational self-interests and that these were reflected in the plans put forward by the air force.

My thesis will also be influenced by another methodological approach. It will provide a basis for assessing the rationality of RCAF policy, doctrine and planning through an examination of how decisions were made and implemented, and whether the end results addressed the initially perceived requirements. To accomplish this, the methodology developed by Alan Millett, Williamson Murray and Kenneth Watman to

\footnotetext{
${ }^{57}$ Desmond Morton, A Peculiar Kind of Politics: Canada's Overseas Ministry in the First World War (Toronto: University of Toronto Press, 1982).
} 
assess the effectiveness of military organizations will be used ${ }^{59}$. They suggest that military structure and effectiveness are interrelated. ${ }^{60}$ This thesis will track how the RCAF structured planning activities and assess how this contributed to its effectiveness.

For the RCAF, political effectiveness relates to being able to convince political leadership that air force needs are more important than those of others. This is accomplished by educating or persuading politicians of increased risk to the nation if more funding is not provided. ${ }^{61}$ How the air force went about attempting to gain the cooperation of the national political leaders will provide the framework for this assessment, through a comparison of stated goals and intentions against outcomes.

This aspect of the Millett, Murray and Watman methodology has been used to assess the effectiveness of large military endeavours, such as the overall success of German military policy during the First World War. ${ }^{62}$ But there is nothing about the way that Millett, Murray and Watman define their theory that excludes its application when examining military activities of a smaller scale, including RCAF postwar activities. The authors show this by including an assessment of the effectiveness of First World War Japan, whose combat role largely consisted of sending a small number of naval vessels to the Mediterranean Sea to assist with escort duties. ${ }^{63}$ After all, effectiveness is just as legitimate a metric for combat between two individuals as it is for the largest military forces - regardless of the size of the force involved, it is either effective or it is not.

\footnotetext{
${ }^{58}$ John Gellner, "Some Thoughts on the Relationship of National Policies and Armed Forces," pp. 53-58 and Richard A. Preston, "The Discussion and Formulation of National Security Policy," pp. 74-83, both in RCAF Staff College Journal - 1959.

${ }^{59}$ Allan Millett, Williamson Murray and Kenneth Watman, "The Effectiveness of Military Organizations," in Allan Millett and Williamson Murray, eds., Military Effectiveness, Volume 1: The First World War (Boston: Unwin Hyman, 1990).

${ }^{60}$ Ibid., p. 1

${ }^{61}$ Ibid., p. 5.

${ }^{62}$ Ibid., pp. 80-116.
} 
However, the analyst must ensure that any assessment of effectiveness takes into account the likelihood of success by the force involved. It would not be reasonable to judge the small Belgian army as ineffective simply because of its failure to repel the invasion by the much larger German forces during the Second World War.

The Millett, Murray and Watman methodology will also be used to examine the strategic effectiveness of military activities designed to carry out national security goals. To accomplish this, declassified intelligence assessments from the period will be critical, since these documents identified the nature of the threat that the armed services, including the RCAF, were responding to and provided clear indications of the kind of capabilities needed by the army, navy and air force. Strategic effectiveness is achieved through an iterative process of negotiations between the political leadership and the military. This dialogue is reciprocal in nature, as political goals inform strategy, but the development of strategic alternatives by the military also help to shape political intentions. Analysis of strategic effectiveness focuses on this reciprocity. ${ }^{64} \mathrm{~A}$ contributing factor in this process relates to how military leaders are able to communicate with and influence political leadership in order to achieve military goals. ${ }^{65} \mathrm{~A}$ final consideration for strategic effectiveness is whether strategic goals are consistent with force size and structure. ${ }^{66}$

Although this methodology is an effective tool, it will not be used to assess the RCAF during the early postwar period. The war weariness of the country, the time it took for a palpable threat to develop and the lack of political support for military

\footnotetext{
${ }^{63}$ Ibid., pp. 229-248.

${ }^{64}$ Ibid., p. 7

${ }^{65}$ Ibid., p. 8.

${ }^{66}$ Ibid., p. 9
} 
spending under Prime Minister Mackenzie King combined to render the air force incapable of achieving any real measure of political or strategic effectiveness for a time. The methodology will be applied only after the RCAF can be viewed as being able to influence defence plans.

My thesis will concentrate one main question: what role did planning and professionalism play in the growth of the RCAF between postwar demobilization and the assumption of NATO commitments in 1950? This period was selected because it represents the nadir and the conditions for the apogee of postwar air force fortunes, in terms of organizational size and capabilities. A range of contributing factors will be examined for their influence upon the outcome of air force planning activities. This includes considerations internal to the RCAF, such as leadership, political influence, organization and structure, policy and practices, and the quality of plans. Quality, in this instance, will be assessed by the level and comprehensiveness of details contained in the plan, and its political, military, economic, and technological viability. Enhanced professionalism was the means by which the air force acquired the experience and ability to take advantage of the opportunities presented by changes to the threat, security, economic and political environments.

Factors explored external to the RCAF include the threat environment, Canadian political and governmental considerations and developments, bilateral and multilateral security arrangements, and relations with the Canadian army and navy. Intelligence appreciations will be used to describe the evolving threat environment, concentrating mainly upon concerns about Soviet aggression and military capabilities, and to determine why the air force was best situated to respond to this threat. Domestic political and 
governmental influences upon the fortunes of the RCAF include political leadership at the head of government and the ministerial level, competing demands upon the government and the public purse, and the influence and opinions of representatives of other government departments, most notably from the Department of External Affairs. Theories of civil-military relations will inform assessments of the interaction between the government and the RCAF. Security arrangements, in the form of the Basic Security Plan with the United States and military commitments under the auspices of NATO, will be reviewed for their influence upon air force plans and fortunes.

The Canadian army and navy were both partners and competitors for the air force in providing for Canadian defence. The air force could provide the response for some threats to Canadian security, but other services also had a role. At times, defensive or offensive measures required the services to cooperate with one another. The government was the arbiter between the three services, deciding what security measures were required. These decisions manifested themselves in terms of budget share. The services emphasized defence roles favourable to their own service and vied for funding. The inter-service rivalry that resulted at times was also influenced by the personal qualities and capabilities of the various service members, especially those in leadership roles. All of these influenced, in varying degrees, the nature and degree of success of RCAF plans. And success for air force plans is an expression of whether and how well they satisfied their intended role.

Most of the records on the RCAF for the period under examination have been released into the public domain. Record Group (RG) 24, LAC, has 5992 linear metres of textual records and contains the bulk of the RCAF documentation. It also holds the threat 
appreciations used for this thesis. LAC's Manuscript Group (MG) includes of the records of William Lyon Mackenzie King (MG 25, J13), Air Marshals Leckie (MG 30 E251) and Curtis (MG 31 G9), and Brooke Claxton (MG 32 B5). Of these personal manuscripts, only the Claxton papers contained much relevant information for this thesis. The Directorate of History and Heritage (DHH), National Defence Headquarters, holds numerous files, including the minutes and records of decision of the Defence Council, the Chiefs of Staff Committee, and the Air Council/Air Members Committees. In addition, DHH holds a large volume of records on RCAF plans, policy, doctrine, and organizational composition and changes, as well as numerous general files related to RCAF unit histories, general operations, procedures and practices. Where possible and appropriate, these records will be used to track the development of air force plans over time in an effort to show where and how senior air force leaders directed decisions to further air force interests.

The first chapter, Visions of a Multi-Purpose Air Force - RCAF Postwar Planning, 1944-45, describes the initial planning for the transition from wartime to a peacetime force. With the growing realization that the Allies were going to win the Second World War, the Canadian government initiated postwar planning activities in 1943. Beginning in 1944, the RCAF saw this as an opportunity to change from its prewar role, initially characterized by a small force with limited military capability providing mapping and charting services and forestry patrols, to a multi-purpose air force capable of performing the full range of military operations experienced during wartime, including bombing, close air support, air interception, surveillance and maritime patrol. Accordingly, RCAF planners embraced the opportunity to preserve hard-won operational 
experience during the war, leading to the unrealistic recommendation in 1944 for a peacetime air force of 150,000 personnel, comprising 30,000 in the Regular Force, 15,000 in the Auxiliary, and 105,000 in the Reserve, along with 16 regular force squadrons and another 28 part time Auxiliary squadrons. This chapter will also examine the postwar planning process, including the creation and composition of the Post Hostilities Problems committee, the direction this committee provided to the RCAF, and how the RCAF went about creating its postwar plans. The contents and intentions of these plans are also reviewed.

The second chapter, "A Very Bitter Stage": Postwar Retrenchment, 1945-1946, looks at the demobilization of the wartime RCAF and the initial postwar plans. The immediate postwar years saw the RCAF drop from almost seventy active service squadrons to a small peacetime establishment. What became known as Plan B called for the Regular Force to serve a training function and to provide the basis for future expansion, while the part-time Auxiliary was intended to fulfil the air interception role against air threats to Canada. ${ }^{67}$

Chapter Two also examines the reasons behind the postwar retrenchment and the level of technology used by the RCAF at this time. It provides an overview of the perception of threat to Canada during this period. The air force's ability to respond to this threat is also reviewed. Moreover, the state of RCAF plans and any gaps between plans and capabilities are scrutinized. The chapter focuses on planning and related developments during the initial period following the end of the Second World War, spanning September 1945 to the end of 1946. Excluded from this review are those

\footnotetext{
${ }^{67}$ To achieve this, 11 Auxiliary squadrons were designated for the interceptor role. RCAF Plan B, April 1946, DHH 181.004 (D49), pp. 18-20.
} 
activities associated specifically with the development of the Basic Security Plan, which is the focus on the next chapter. During this initial postwar period, the air force demobilized, established terms of service and recruited for a peacetime force, thus laying the groundwork for the postwar RCAF. As part of this examination, such issues as the reasons behind the postwar retrenchment and the state of RCAF policy and plans are explored.

The third chapter, The Basic Security Plan - Planning for North American Air Defence, 1946-1948, considers the circumstances surrounding RCAF plans for domestic security. In late 1945, Canadian political and military leadership knew that the wartime Canada-United States Defence Plan, ABC-22, had to be updated to consider the postwar environment and the military was authorized to collaborate with their American counterparts. Consequently, much of the staff planning effort between 1946 and 1948 went into development of the "Basic Security Plan" with the United States. This period proved to be critical for the RCAF, as the growing perception of the Soviet threat and the need for enhanced air defence for North America were central to the future growth of the air force. This chapter describes the evolution of the Basic Security Plan and developments in the defence relationship with the United States. It also provides details on the interaction between the Canadian military and the government, as well as between the Canadian Army and the RCAF, and explores the nature and scope of changes for the RCAF resulting from the Basic Security Plan.

The fourth chapter, Rebuilding the RCAF, 1947-1948, explores details of plans that led to the initial expansion of the postwar air force. Given the experiences of the preceding two years, it would be understandable if RCAF leaders approached the 1947- 
48 period with apprehension. But there was cause for hope, as negotiations and planning activities had begun with the United States. The increasing realization of the threat of Soviet airpower would provide much of the substantiation for a significant increase to the size and role of the RCAF.

Chapter Four begins by reviewing the cause and results of cutbacks in early 1947 and assesses the state of the air force. An assessment of the implications for the Basic Security Plan follows, and the development of the follow-on to Plan B, first Plan E and then Plan F, are explored. Given its importance, Plan F will be examined in detail, including a description of how the RCAF managed its implementation. This chapter also describes events related to the termination of the Interim Air Force and establishment of the Regular RCAF, along with developments associated with the Auxiliary RCAF. An important institutional change during this period, the creation of a senior level champion for planning, the Air Member for Air Plans, is described, as is the impact of the planning infrastructure established under him. This resulted in increased professionalism, a widening of the scope of air force planning and enhanced effectiveness of RCAF planning activities. Finally, this chapter traces the evolving threat environment as it was described in a series of appreciations and assesses how the RCAF responded to it.

The fifth chapter, Gaining Influence: The Rise of the RCAF, 1949, explores the continued evolution of planning within the RCAF. It begins with an exploration of how the RCAF developed an Air Defence Plan and the affect of periodic intelligence appreciations upon plans. Associated with this will be an examination of how the RCAF planned to acquire the new interceptor capability, including an analysis of how and why some alternative solutions for were rejected. As well, the impact of a new defence 
alliance is reviewed, along with the reaction to the detonation of the Soviet Union's first atomic weapon. I argue that this series of events combined to create circumstances very favourable to the expansion of the RCAF and facilitated an enhancement to its role in providing security for Canada.

The final chapter, A Revitalized Air Force: RCAF NATO and Air Defence Planning, 1950, examines a period of unparalleled RCAF peacetime expansion. With the outbreak of the Korean Conflict, the threat from the Soviet Union was perceived as becoming more serious and there was increased impetus behind the establishment of a credible military counterbalance across NATO. Simultaneously, the RCAF refined and fielded segments of the air defence measures for North America. During this year, the RCAF received approval for an increase from nine Regular force squadrons and 10 Auxiliary squadrons in early 1950 , to a force of 28 (16 Regular and 12 Auxiliary), followed by approval for a further expansion to more than 40 squadrons (29 Regular and 12 Auxiliary). This peacetime growth in approved establishment by more than 100 percent over a little more than 12 months was unmatched in scope over the entire history of Canadian military history.

The dissertation concludes with a review of how the RCAF came to play an important postwar role. A range of factors are considered, with the primary focus on the role of planning and professionalism. These were critical in the making of a Cold War air force. 


\section{CHAPTER ONE}

\section{VISIONS OF A MULTI-PURPOSE AIR FORCE:}

\section{RCAF POSTWAR PLANNING, 1944-1945}

Preparation for the immediate postwar RCAF was inextricably linked to the political, strategic and military environment of the final years of the war. In mid-1943, as it became evident that the Allies were going to win, ${ }^{1}$ the Canadian government began the process of postwar planning. As part of this, air force planners started to put thought into the desired size, structure and role of the postwar RCAF. Plans were the means by which the peacetime air force defined how it developed, prepared to go to war and carried out the directions of the Minister of National Defence. They also directly affected how, or even if, the RCAF would support the army, navy and other government departments. These plans allowed the air force to exploit opportunities and further its interests and, as such, were crucial to the future of the RCAF.

Influenced by memories of the post-First World War severe reductions experienced by the armed forces, the RCAF was careful to put forward plans for a balanced, multi-purpose force, capable of fulfilling a wide range of air force roles, including fighter-interceptors, reconnaissance, mapping and charting, transport, tactical

\footnotetext{
${ }^{1}$ The combination of a series of German defeats and Allied victories (Stalingrad, El Alamein, Kursk, the Allied landing in North Africa, the successful Allied invasion of Sicily) from 1942 to July 1943 and the concurrent political and military planning foreseeing an Allied victory (Roosevelt's and Churchill's January 1942 proclamation of The Grand Alliance, the Casablanca conference during January 1943, the first Quebec Conference in August 1943, the planning for the September 1943 invasion of Italy and preplanning for the subsequent 1944 invasion of the European mainland) provided the basis for such Allied postwar planning. See, for example, Martin Gilbert, Winston S. Churchill: Volume VII, Road to Victory, 1941-1945 (Boston: Houghton Mifflin, 1986), and Richard Overy, Why the Allies Won (New York: W.W. Norton \& Company, 1996). For details from those involved in the conduct of the Second World War, see Winston S. Churchill, The Second World War - The Hinge of Fate, Volume 4 (Boston: Houghton Mifflin Company, 1983) and Arthur Bryant, The Turn of the Tide - A History of the War Years Based on the
} 
support and light-medium bombers. The RCAF had reasons to believe that as the war ended, their planning activities would result in the realization of this goal. As events were to turn out, this confidence was misplaced.

The purpose of this chapter is to examine the process and results of RCAF postwar planning between 1944 and 1945, including how this activity originated, the guidance received from government that influenced this planning, the considerations internal to the RCAF that affected the results of this process and the procedures followed to arrive at the conclusions. It will finish with an outline of the proposed composition of the postwar air force when hostilities ended in Europe in May 1945.

\section{The Post-Hostilities Problems Working Committee}

The genesis for the postwar Royal Canadian Air Force, Royal Canadian Navy and Canadian Army may be found in the Post-Hostilities Problems (PHP) Working Committee formed by the Canadian government in 1943 to consider the return to a peacetime political, social, and economic environment. ${ }^{2}$ This working committee, as part of the government's overall postwar planning, acknowledged that a range of security issues had to be resolved. This included defining the threats to national security, developing appropriate defence policies in response to these and building the defence infrastructure required to carry out the defence policies. On 6 January 1944, the committee solicited views from the three services on future defence requirements, at which time only the Canadian Army indicated that work had begun on postwar planning

Diaries of Field-Marshal Lord Alanbrooke, Chief of the Imperial General Staff, 1939-1943 (New York: Doubleday \& Company, 1957).

${ }^{2}$ Minutes of meeting held on 22 July 1943 to consider post-hostility problems, National Archives of Canada (LAC), Record Group (RG) 24, Vol 6170, file HQ 15-48-1, Vol 1. 
- neither the air force nor the navy were yet considering their future. A concern immediately expressed by the military was that some level of direction was required from the government, to provide a measure of the scope and scale appropriate for such planning. ${ }^{3}$ In part, this direction came in the form of two PHP Working Committee studies, one of which sought to articulate the issues related to regional security and defence. The other explored considerations related to postwar defence cooperation with the United States.

The first of these papers was released in April 1944 and viewed security organizations as an effective means of avoiding war and preventing attack from the outside. It noted the interwar failure of the League of Nations, in part because of the complexity of dealing with multiple nations on global security issues. To simplify matters, this report recommended that security be examined from a limited, regional perspective. From a Canadian viewpoint, the Working Committee saw regional security organizations as the means to avoid conflict between neighbouring nations and a way for a smaller nation to have a greater role than in a worldwide security union. Moreover, such close collaboration between neighbours would provide the opportunity to standardize equipment and training, which would help the conduct of joint operations. ${ }^{4}$

A major disadvantage of a regional security organization was that it could promote a return of isolationism if nations took interest only in conflict within their own region. There was also concern that the arbitrary and artificial geographic division of areas such as Greenland, Iceland and the Suez Canal would take place, with powerful

\footnotetext{
${ }^{3}$ LAC, RG 24, Vol 6170, File HQ 15-48-1, Vol 1, "Minutes of the $11^{\text {th }}$ Meeting of the Working Committee on Post-Hostilities Problems, held in Room 123, East Block, Thursday, 6 January [1944], at 4:30 o'clock", p. 3.
} 
nations seeking to extend their security perimeter and area of influence. This could result in some wider security problems should different nations seek to assert authority over one another in these areas. In addition, there was apprehension that a false sense of security could develop for some nations because of the large bodies of water separating the various regions. Concern was also expressed that the United States, as the largest power within a North American region, would dominate Canada. Related to this was the acknowledgment that Commonwealth ties could weaken as the result of participation in a regional security organization. ${ }^{5}$

In considering regional defence issues, the PHP Working Committee anticipated that advances in the range and power of weapons required national defence arrangements to provide protection beyond state boundaries. A suitable Canadian defensive perimeter included an inner circle taking in Newfoundland, Alaska, and the continental United States, and an outer ring consisting of Greenland, Bermuda and Hawaii. In the eyes of the Working Committee, some sort of regional defensive arrangement, in the form of an alliance, would best serve Canadian interests by helping to establish this perimeter and to discourage aggression from outside. ${ }^{6}$

Still, if Canada were to participate in a regional defence arrangement, potential problems areas had to be considered in advance. The largest partner in such an agreement could treat the entire region as its sphere of influence and ignore the national rights of the smaller participant in the agreement. Using the United States as an example, concern was expressed that Canada could be placed in an awkward position if the

\footnotetext{
${ }^{4}$ LAC, RG 24, Vol 6170, File HQ 15-48-2A, C.P.H.P. (44) Report 2 (Final), entitled "Advantages and disadvantages of the regional organization of security and defense", [April 1944], pp. 1-2.

${ }^{5}$ Ibid., p. 2.

${ }^{6}$ Ibid., p. 3.
} 
Americans insisted on building defensive measures in Canada to protect against a possible attack from the Union of Soviet Socialist Republics (USSR). The paper acknowledged, however, that such pressures were inevitable in any defensive arrangement in which there was a great disparity between the relative strengths of participants. The paper concluded that, regardless of the possible problems, the development of a North American defensive arrangement would be to Canada's advantage. $^{7}$

The second of the papers from the PHP Working Committee, completed in June 1944, further developed the idea of the formation of a postwar defence arrangement with the United States. It approached this issue by first examining the implications of three different aspects of security for Canada. These included participation in the static defence of North America, which implied closer security ties with the United States, continuation of the defence relationship with the British Commonwealth and especially with Great Britain, and military obligations that might be created with the establishment of a new world security organization. ${ }^{8}$ A link was seen between North American defence and any new global security organization, since naval and air staging bases in Canada would be required to facilitate the deployment of forces from North America to Europe or northeastern Asia. The Canadian defence relationship with Great Britain was considered likely to continue for a period, not only due to the training and equipment standardization

\footnotetext{
${ }^{7}$ Ibid., p. 4

${ }^{8}$ DND, DHH, file 193.009 (D33), CSC Miscellaneous Memoranda, Jun/Jul 1944, Volume 32, "Report to the Advisory Committee from the Working Committee on Post-Hostilities Problems - Post-War Defence Arrangements with the United States - Preliminary Paper", 16 June [1944], p. 1.
} 
between the two countries, but also because of political considerations associated with belonging to the British Commonwealth. ${ }^{9}$

Canada understood that its best interests lay in defensive collaboration with a close regional ally, but found that British-inspired traditions and cultural considerations pulled it in a different direction from the geographic reality of a North American nation bordering the modern world's first true military superpower. Canada clearly had to choose either Great Britain or the United States of America as its premier ally, since mutually cooperative defensive policies had to be worked out, practices and tactics had to be harmonized in order to foster operational efficiency, and equipment had to be standardized to ensure compatibility. As events unfolded, the changing international political landscape, advances in technology and the nature of the evolving military threat played a significant role in helping Canada determine what was in its best interests.

The PHP Working Committee believed that, with the eventual defeat and disarming of Japan and Germany, there would be no direct threat to North America for at least ten years. The Committee also concluded that the recovery and development challenges facing the USSR after the war precluded any major Soviet aggression for at least a decade. ${ }^{10}$ As a result, it was anticipated that Canada's postwar defensive measures could be developed and implemented over a number of years, with adjustments as circumstances warranted.

With these considerations in mind, the PHP Working Committee believed that Canada and the United States should continue with the kind of defensive cooperation established with the creation of the Permanent Joint Board on Defence (PJBD) in 1940.

\footnotetext{
${ }^{9}$ Ibid.

${ }^{10}$ Ibid.
} 
Acknowledging that such cooperation would entail joint planning and the construction of staging facilities in Canada for deployments outside of North America, the Working Committee had concerns about sovereignty and asserted that Canada would not be willing to see non-Canadian defence installations established and maintained within its territory. However, it was also known that American concerns about an attack from the USSR would influence Canadian decisions about men, material, airfields, coastal defences, naval bases and radar. This, in turn, would affect the nature of Canada's relationship with the USSR, which was seen as being of less national importance than that between Canada and the United States. The paper concluded with a recommendation that an effort be made to link any defensive arrangement with the United States to the general organization of world security. ${ }^{11}$

This kind of geopolitical pragmatism was an enduring element of Canadian politics, diplomacy and military planning, with relevance for postwar security arrangements. During the Second World War, Mackenzie King did not seek involvement in the higher direction of the war and was content with acknowledgement and recognition of Canada's contribution to the war effort. ${ }^{12}$ When the United States began to take Canada for granted, the Canadian government protested, often to the bewilderment of the Americans, who came to consider Canada "not as a foreign nation, but as one of themselves". Should this kind of presumptive behaviour continue into the postwar period, Canada would be in danger of losing its voice and being disadvantaged in any regional security arrangement with the United States. In order to mitigate the power the

\footnotetext{
${ }^{11}$ Ibid., p. 2.

${ }^{12}$ Denis Stairs, "Realists at Work: Canadian Policy Makers and the Politics of Transition from Hot War to Cold War", p. 94, in Greg Donaghy, ed., Canada and the Early Cold War, 1943-1957 (N.p.: Department of Foreign Affairs and International Trade, 1998).
} 
United States would have in a strictly bi-lateral security arrangement, it was in Canada's interest to promote the United Nations and international agencies. ${ }^{13}$

Elements of these two PHP Working Committee papers show other uncertainties within Canada about the development of a closer relationship with the United States. Canada at times wanted to obtain greater security from attack by allying with a powerful nation, but was equally worried that linking with the United States would adversely affect its relations with the Soviet Union. Canada sought to align itself further as a North American country, but felt the pull of and saw the use of the British Commonwealth and other international institutions. The ebb and flow of government sentiment in this respect would provide challenges for the air force, and the other services, when developing plans for the postwar environment.

By mid-1944, these PHP Working Committee studies provided some of the initial, albeit conflicting, political and strategic context for RCAF postwar planning. This committee, on behalf of the Canadian government, foresaw a range of possible postwar security arrangements, influenced alternatively by continental, global and Commonwealth considerations. Based upon the threat assessments produced in support of the committee, the government realized that continental defence arrangements made with the United States during the war should continue, but the pre-war practice of collaborating with Great Britain still held some appeal. While it was clear that Canada's role in any security and defence alliance would be that of a junior partner, issues associated with global conditions, territorial sovereignty and technology added complexity to the military planning process.

\footnotetext{
${ }^{13}$ Ibid., pp. 98-99.
} 
In the end, the two government studies provided a measure of strategic guidance to the military on which to base postwar planning, in the form of the security assessments and direction on likely security partners. The political direction to the RCAF and the other armed services has to be viewed, however, as limited and providing an incomplete basis upon which to base future planning. Personnel levels, budgetary constraints, and domestic considerations, such as the need to spread military forces across the country, were not identified to RCAF planners as factors to be considered. This absence of political and economic constraints allowed the air force to initially put forward plans without consideration for non-military factors - for example, a limit to the funds likely to be made available by the government.

Despite this shortfall in guidance, the RCAF must bear significant responsibility for any planning activities carried out without an eye to constraints. The pre-war RCAF clearly was restricted in strength and budget, so there was no basis for air force planners to assume that the RCAF would have limitless resources available in the postwar. Following the First World War, the Canadian military was significantly reduced in strength and budget, and there was every reason to believe that the post-Second World War government would do the same. Since no threat to North America was foreseen for at least a ten-year period, the argument for a large army, navy or air force was difficult to make. The Post-Hostilities Problems Working Committee had anticipated that Canada would operate as a subordinate member of a bilateral or multilateral alliance, which suggests that the military strength of another nation would provide a measure of protection for Canada. The implication of this is that Canada would not require a military capable of independent operations. 
RCAF planners should have considered these factors as part of their planning process, which point towards the requirement for a small, multi-purpose force that could be used for the basis of future expansion. But the air force, as was the case for the army and navy, missed these indications and proceeded to make plans for a postwar force largely without concern for the political and economic realities that would be faced. ${ }^{14}$

\section{Initial RCAF Postwar Planning}

Two months after the January 1944 PHP Working Committee request for input into postwar defence planning, the Canadian military's Chiefs of Staff Committee (CSC) (comprising the three service heads) reacted by tasking the services to produce papers and studies that "will take into consideration the broad military and political aspect of Canada's post-war defence commitments and it is desirable that the Services should actively participate from the inception in their production and take a definite hand in the writing required." Specific direction to the army, navy and air force included advice which took into account the advantages and disadvantages to Canada of organizing world security on a regional or universal basis. Guidance was also provided on postwar defence arrangements with the United States, Canadian policy towards the defence of Newfoundland and the Canadian role in defence of the north Pacific region. ${ }^{15}$

An initial response to the direction of the CSC and PHP Working Committee came from the Plans division of RCAF Headquarters, which identified what became a recurring theme heard from the pre-war generation of air force officers. Since its

\footnotetext{
${ }^{14}$ By focusing on purely military matters and not considering political or economic factors, the services essentially took a Huntington approach.
} 
inception, the RCAF had worked closely with its British counterpart, the Royal Air Force (RAF). The RCAF's rank structure and traditions were inherited from the RAF, advanced training for RCAF officers before and during the war was received in Great Britain, and the RCAF had fought with and under the RAF during the Second World War. Any proposal to establish closer defence ties with the United States was examined partially through the prism of how relations with the British would be affected. Group Captain W.F. Hanna, who was involved in the development of RCAF plans in 1944, expressed concern that standardizing equipment and organization with the United States would hinder the ability to operate in times of war with British forces. He also suggested that, should the United States return to isolationism, Canada would be placed in the awkward position of being in conflict with Commonwealth policy. He went on to state that:

With the growth of both land-based and carrier-based air power, and with increases in the range and destructiveness of aircraft, frontier defences will become of less and less significance. In view of these developments, therefore, it would seem to be an illusion for Canada to place too much faith in a policy of collaboration with the United States as a basis for security. Rather, it is considered that Canada should, with the other Nations of the Commonwealth, accept a fair share of responsibility in an international security organization and be prepared at all times to strike at aggression wherever it may arise. ${ }^{16}$

This view ultimately would not hold much sway.

On 16 May 1944, the RCAF established the Post War Organization Committee, which was tasked to "develop and prepare proposals for the Organization, Operation and

\footnotetext{
${ }^{15}$ Department of National Defence (DND), Directorate of History and Heritage (DHH), file 193.009 (D29), CSC Miscellaneous Memoranda, Feb/Mar 44, Vol 28, HQS 9072-5 (Oprs), entitled "Post-Hostilities Planning", dated 18 March 1944.

${ }^{16}$ LAC, RG 24, Vol 7170, file 15-48-2, Vol 1, memorandum entitled "Canadian Defence Relationship with the United States", S. 15-9-86 (Plans JP), 4 May 1944, from G/C W.F. Hanna, AMAS D/Plans (JP) to AMAS.
} 
Administration of the Post War RCAF, including Regular, Auxiliary, and Reserve." ${ }^{, 17}$ It included Air Commodore H.L. Campbell (Regular Force), Group Captain J.L. Plant (Regular Force), Wing Commander S.W. Coleman (Regular Force), Group Captain W.F. Hanna (Auxiliary Force) and Group Captain Z.L. Leigh, (Reserve Force). The Regular RCAF consisted of fulltime, professional members of the air force; the RCAF Auxiliary was comprised of citizen airmen, who trained part-time with the air force; and the RCAF Reserve, which included ex-members of the RCAF Regular, Auxiliary, Reserve and Special Reserve Forces who were still eligible for regular service. Both the Auxiliary and Reserve Forces could be called into fulltime service in the event of a national emergency, including war. While a number of the Organization Committee members came from the RCAF Headquarters group responsible for planning under the Air Member for Air Staff, it was headed by the Assistant Chief of the Air Staff, H.L. Campbell, which suggests the importance given to it.

In the months that followed, the Post War Organization Committee held a series of meetings and interviews, and received oral and written submissions from interested parties. The pre-war RCAF had only eight regular squadrons (seven of which were equipped with outdated aircraft). It had a total establishment of 3048 personnel, including 235 pilots, and a skeletal Auxiliary organization. On paper there were 12 Auxiliary squadrons; in reality this organization had few (and obsolete) aircraft and an establishment of only 1013 personnel. ${ }^{18}$ Based upon this prior experience, the committee

\footnotetext{
${ }^{17}$ LAC, RG 24, Vol 5224, file S-19-7-71, Vol 1, Secret Organization Order No. 196, file C.19-7-71 (DEO), 16 May 1944.

${ }^{18}$ W. A. B. Douglas, The Creation of a National Air Force: The Official History of the Royal Canadian Air Force, Volume II (Toronto: University of Toronto Press, 1986), pp. 150-151, and Brereton Greenhous et al, The Crucible of War, 1939-1945: The Official History of the Royal Canadian Air Force, Volume III (Toronto: University of Toronto Press, 1994), p.16.
} 
initially sought to limit the scope of any postwar Regular RCAF. They reasonably agreed amongst themselves to "the general principle that the purpose of the Regular Air Force would be to maintain a few active up-to-date squadrons, and keep at a standard of efficiency the Auxiliary Air Force and Reserve Force." As a preliminary estimate of the size of the future air force, the committee understood that the Minister of National Defence for Air and the Chief of the Air Staff had agreed on a postwar Regular RCAF of 30,000 personnel, with 15 squadrons and four commands. ${ }^{19}$

As part of the planning for the postwar RCAF, the question of social composition, which was linked to the issues of class and pay, was examined. The British Army had traditionally reserved access to the officer corps for the upper class, at first through the purchase system for initial commissions and subsequent promotions, and later by the lack of adequate pay for serving officers. Without private wealth, British officers were hard pressed to maintain the lifestyle that was expected of them. ${ }^{20}$ The Post War Organization Committee received a proposal along these lines, with a written submission advocating that RCAF Auxiliary officers "should have independent means and be willing to pay for their own uniforms, annual mess assessments, and be willing to turn their pay to the airmen's and officers' mess. Those who cannot afford the above should join the flying clubs. ${ }^{21}$ This recommendation, which would have resulted in an upper class Auxiliary officer corps, was not supported. The Chief of the Air Staff, Air Marshal Robert Leckie,

\footnotetext{
${ }^{19}$ LAC, RG 24, Vol 5226, file HQS. 19-7-71A, Vol 1, Department of National Defence for Air, Post War Organization Committee - Minutes of Meeting No. 1 held 30 May 1944, at 0930 Hours, p. 1.

${ }^{20}$ Sir William Robertson, who served as Chief of the Imperial General Staff during the First World War, came from humble beginnings and as a junior officer was reduced to drinking water in the mess while his peers had champagne. Gary Mead, The Good Soldier: The Biography of Douglas Mead (London: Atlantic Books, 2007), p. 52.

${ }^{21}$ LAC, RG 24, Vol 5224, file S-19-7-71, Vol 1, memorandum S.19-7-71 (AMO), 14 June 1944, from Air Vice Marshal F.S. McGill, AMO, to Chairman, Postwar Organization Committee.
} 
played a role in this, as he strongly advocated that the air force be accessible to Canadians of different backgrounds and educational attainment.

Before examining the findings and recommendations of the Post War Organization Committee, it is instructive to review the approach taken by it. The committee had the ability to consult widely, with no limitations identified for how it was to perform its duties. Nor was there a preconception about what form the postwar air force was to take, thus allowing committee members to consider the full range of air force roles available. The committee itself was intended to be reflective of a broad approach to postwar planning, since its composition included representatives from the RCAF Regular, Auxiliary and Reserve Forces. It would have been influenced by pre-war traditions and experiences, but wartime service affected the way in which they viewed the air force of the future. Despite the authority for broad-based consultation, the committee essentially sought advice only from within the air force community, obtaining no substantive input from outside of the air force beyond reference to a number of PHP Working Committee threat assessments. The committee planned for a postwar organization with little consideration for the political or economic factors that could place limitations on its intentions. It also accepted at face value the understanding between the Minister of National Defence for Air and the Chief of the Air Staff that the future size of the Regular RCAF was to be 30,000 . A more cautious approach would have been to consider a range of options for future air force roles and responsibilities, and to provide contingency plans for various manpower and funding levels. 


\section{RCAF Postwar Organization Proposals}

One of the initial planning activities considered was what form the postwar RCAF Auxiliary would take. The Organization Committee received opinions about entry requirements into the peacetime Auxiliary Force, in anticipation that "there will be a tremendous number of personnel wishing to join the various auxiliary squadrons" based upon their experience in the wartime air force. In this belief, the committee recommended high medical and educational standards for potential recruits for the postwar Auxiliary. ${ }^{22}$ Such opinions about the appeal of further service with the RCAF are questionable, as the committee failed to consider the possibility of postwar fatigue with military service and that civilian employers would be competing for personnel. Nor was this optimism based upon pre-war experience: the air force at that time did screen potential recruits in order to obtain the best possible candidates, but it was not an employer of choice and few applied. Although the RCAF preferred to have an officer corps with university degrees, the post-First World War pilot courses had to accept applicants without that qualification. ${ }^{23}$ The Post War Organization Committee had no reason to believe that things would change for the post-Second World War air force, but it made the mistake of assuming that the air force would have no difficulty in attracting personnel.

Continuing their examination of postwar Auxiliary RCAF requirements, the Committee heard from Group Captain Hanna, one of its members and the sole

\footnotetext{
${ }^{22}$ Ibid.

${ }^{23}$ For instance, Air Vice Marshal Roy Slemon was recruited and trained before completion of his degree. He was later required to return to university or face expulsion from the air force. See Sandy Babcock, "Roy Slemon, the Air Force Original", in Lieutenant Colonel Bernd Horn and Stephen Harris, eds., Warrior Chiefs: Perspectives on Senior Canadian Military Leadership (Toronto: Dundurn Press, 2001).
} 
representative of the Auxiliary. He pointed out that, although the pre-war Auxiliary had "left much to be desired", it still comprised the majority of the first three squadrons sent overseas. Given the small Canadian population, Hanna felt that a large regular air force could not be supported in peacetime and "must rely rather on specially trained reserves which can be brought to operational standards with a minimum of delay". In order to fulfil the range of roles that it could be called upon to do, he recommended that the Auxiliary have a mobile striking force of fighters and bombers, coastal squadrons for the protection of shipping lanes, and a tactical force for cooperation with the Canadian Army. ${ }^{24}$ As a partial consequence of this submission, the committee later proposed a postwar Auxiliary force of 28 squadrons, including nine fighter squadrons, nine medium bomber squadrons, eight fighter-bomber squadrons and two Photo-Reconnaissance Squadrons. In considering population base, the need to spread the squadrons between provinces, and infrastructure requirements (i.e., the existence of an airfield), the committee proposed to distribute these squadrons as depicted in Table $1 .{ }^{25}$

The Organizing Committee also believed that the Auxiliary squadrons should be formed as soon as possible after the war, so that the names and traditions of the wartime squadrons that had distinguished themselves would be carried on. This would be accomplished, in part, by perpetuating the same squadron numbers and, where possible, the same aircraft types used during the war. Since there were 48 active service squadrons

\footnotetext{
${ }^{24}$ LAC, RG 24, Vol 5226, file HQS 19-7-71A, Vol 1, Air Post War Organization Committee, Meeting 5, held 27 June 1944, at 0930 hours. Attached to these minutes was a memorandum from Group Captain W.F. Hanna, entitled "R.C.A.F. Auxiliary Squadrons", (N.D.).

${ }^{25}$ Ibid. While the text of the Post War Organization Committee meeting minutes indicated eight fighter squadrons and nine fighter-bomber squadrons for the Auxiliary, Annex B to these minutes provided a chart similar to that reproduced here, which indicated the nine fighter and eight fighter-bomber squadrons. This distribution was confirmed in the Committee's final recommendations, LAC, RG 24, Vol 5226, file S-19-771A, Vol 1, Post War Organization Committee Minutes of Meeting No. 18 held on the $7^{\text {th }}$ September, 1944, at 1930 hours, Annex B, p. 12, refers.
} 
Table 1: Postwar Auxiliary Squadron Proposal

\begin{tabular}{|l|c|l|l|l|}
\hline Location & Fighter Sqns & $\begin{array}{l}\text { Medium } \\
\text { Bomber Sqns }\end{array}$ & $\begin{array}{l}\text { Fighter Bomber } \\
\text { Sqns }\end{array}$ & $\begin{array}{l}\text { Photo-Recon- } \\
\text { naissance Sqns }\end{array}$ \\
\hline Vancouver & 1 & 1 & 1 & \\
\hline Victoria & & & 1 & \\
\hline Edmonton & 1 & & 1 & \\
\hline Calgary & 1 & & & \\
\hline Regina & & 1 & & \\
\hline Saskatoon & 1 & & & \\
\hline Winnipeg & 1 & 1 & & \\
\hline Windsor & & 1 & & \\
\hline London & & & & \\
\hline Hamilton & & 1 & & \\
\hline Toronto & 1 & 1 & & \\
\hline Ottawa & & 1 & & \\
\hline Montreal & 1 & 2 & & \\
\hline Quebec & 1 & & & \\
\hline Moncton & 1 & & & \\
\hline Halifax & & & & \\
\hline $\begin{array}{l}\text { Sydney and } \\
\text { Glace Bay }\end{array}$ & & & & \\
\hline Charlottetown & & & & \\
\hline Total & 9 & 9 & & \\
\hline
\end{tabular}

during the war, the creation of 28 postwar Auxiliary squadrons would have gone a long way towards preserving the names of the existing wartime operational flying units. ${ }^{26}$ When considered in concert with the 16 Regular RCAF squadrons to be established postwar, only four wartime units would have been disbanded. ${ }^{27}$

The committee then turned its attention to the requirements for the postwar Regular RCAF, with initial discussion indicating a preference for 16 squadrons (one more than the guidance provided by the Minister of National Defence for Air and Chief

\footnotetext{
${ }^{26}$ LAC, RG 24, Vol 5226, file S-19-7-71A, Vol 1, memorandum C. 19-7-71 (AMT), 13 July 1944, from Air Vice Marshal A. De Niverville to Chairman, Post War Organization Committee.

${ }^{27}$ The number of overseas squadrons is not a clear cut matter. Brereton Greenhous et al, op. cit., p. 14, indicates that there were 47 overseas squadrons, but this total does not include Eastern Air Command's No. 162 Squadron, which served with Coastal Command from January 1944. For the purposes of this thesis, the number of overseas squadrons will be assessed as 48 .
} 
of the Air Staff). Anticipated squadron requirements included two fighter, two fighterbomber, two medium bomber, four very long-range reconnaissance, two flying boat and one photographic. An additional three transport squadrons were spread out between Debert and Dartmouth, Nova Scotia, Kingston and Rockcliffe, Ontario, and Gimli, Manitoba. ${ }^{28}$

One of the major concerns of the air force was the need to retain its hard-won wartime operational skills and to avoid the pre-war practice of employing the regular air force mainly on forestry patrols, aerial photography and police liaison. ${ }^{29}$ This led a senior RCAF officer to assert that the "Post War Air Force should not undertake flying operations of a commercial nature such as were carried out before the war. This has had the effect in the past of retarding the progress of both civil aviation and the Air Force. It is considered that the Air Force should confine its activities to those of a nature which are strictly within its proper functions as an Air Force. This refers particularly to photographic surveys, transportation, etc., which field the Air Force should quit as soon as possible after the armistice." ${ }^{30}$

By September 1944, the Post War Organization Committee had completed its final report. The committee had come to the conclusion that the air force's size should be roughly proportional to that being planned for the United States, based upon Canada's population and resources. This led to an initial recommendation that there be an establishment of 150,000 personnel, comprising 30,000 in the Regular Force, 15,000 in

\footnotetext{
${ }^{28}$ LAC, RG 24, Vol 5226, file HWS 19-7-71A, Vol 1, Air Post War Organization Committee, Meeting No. 6, held 3 July, 1944, at 1015 hours, and file S-19-7-71A, Vol 1, Post War Organization Committee Minutes of Meeting No. 18 held on the $7^{\text {th }}$ September, 1944, at 1930 hours, Annex B, p. 7.

${ }^{29}$ Greenhous et al, op. cit., p. 16.

${ }^{30}$ LAC, RG 24, Vol 5226, file S-19-7-71A, Vol 1, memorandum C. 19-7-71 (AMT), 13 July 1944, from Air Vice Marshal A. De Niverville to Chairman, Post War Organization Committee.
} 
the Auxiliary, and 105,000 in the Reserve. ${ }^{31}$ This proposal for establishment numbers was later cut back to 95,000 through a reduction of Reservists to 50,000. To achieve a force of this strength, the committee proposed that compulsory military service be adopted by the federal government. Given the nature of the national crisis over conscription during the war, this provided a strong indication that the Committee's work was being completed without significant governmental or political oversight. ${ }^{32}$ Concluding that the main responsibility of the RCAF was to "maintain an air force in strength and readiness to uphold national policies and interests and to guard Canada from air attack", the Committee identified three roles for the Regular RCAF as part of the postwar plans. These included "[m]aintaining the requisite number of fully trained and equipped Regular squadrons", "[p]roviding effective training for the R.C.A.F. (Auxiliary) and R.C.A.F. (Reserve)", and "[p]roviding training to its own personnel such that they will be equipped to undertake positions of greatly increased responsibility in the event of any rapid expansion of the R.C.A.F.". ${ }^{33}$ This peacetime regular force was to consist of men only, with the Post War Organization Committee recommending the disbandment of the RCAF Women's Division (W.D.). Committee members also decided that women would not be allowed to enlist in the postwar Auxiliary or Reserve either, since they believed that women "have almost no continuing interest in the R.C.A.F. and

\footnotetext{
${ }^{31}$ LAC, RG 24, Vol 5226, file S-19-7-71A, Vol 1, Post War Organization Committee Minutes of Meeting No. 18 held on the $7^{\text {th }}$ September, 1944, at 1930 hours, Annex B, p. 1. In order to keep their skills, the Reserves were to be provided with 28 training days per year. Auxiliary personnel were also to receive 28 days of training per year, but these were described as "intensive". At the $28^{\text {th }}$ Meeting of this committee, held on 10 October 1944, the recommended number of Reserve personnel dropped to 50,000 and at LAC, RG 24, Vol 5226, file S-19-7-71A, Vol 1, Post War Organization Committee Minutes of Meeting No. 18 held on the $7^{\text {th }}$ September, 1944, at 1930 hours, Annex B, p. 12, the training requirement for the Reserves dropped to 28 days for fifty percent of personnel, with no such training provided for the remainder. ${ }^{32}$ See J.L. Granatstein and J.M. Hitsman, Broken Promises - A History of Conscription in Canada (Toronto: Oxford University Press, 1977), for details about the conscription crisis and the politics associated with it.
} 
W.D. membership in Reserve and Auxiliary would rapidly become non-effective. ${ }^{34}$

This decision was reached despite submissions to the committee advocating retention of the Women's Division and assertions from senior personnel that women had been of "immense value" during the war. ${ }^{35}$ Eventually, all women were released from the RCAF effective 31 December 1946. It was orchestrated, as a public relations exercise, so that the last woman to leave the air force would be "photogenic", and not based upon merit, or length and quality of service. ${ }^{36}$ There was no explanation as to why men would have more "continuing interest" in serving than women.

The RCAF also realized that the nature of modern combat was changing and that this had implications for the role and requirements of an air force. The air force needed to develop a plan to introduce newer equipment while phasing out wartime stock. This was made more complex by the need to consider what roles the air force would have, which would directly influence the types and quantities of aircraft that were required. Cargo aircraft, for instance, were required for transporting personnel and equipment. Fighters were needed for the air interception role. Long-range patrol aircraft would be necessary for the surveillance of national boundaries and maritime approaches. In a submission to the Post War Organization Committee, the Director of Future Plans, Wing Commander G.S. Austin, noted that developments "during the present war seem to indicate that practically all military operations now and in the future must be combined

\footnotetext{
${ }^{33}$ Ibid., Annex B, p. 2.

${ }^{34}$ Ibid., Annex B, p. 3.

${ }^{35}$ LAC, RG 24, Vol 5226, file S-19-7-71A, Vol 1, memorandums S. 140-196 (AOC) C-19-7-71 (AMO) RP2, 15 June 1944, from Air Vice Marshal A.T.M. Cowley, AOC, No. 1 Training Command refers. See also S. 1-1-3 (AFCS), 20 June 1944, from Air Vice Marshal George V. Walsh, Canadian Joint Staff, Washington refer.

${ }^{36}$ LAC, RG 24, Vol 3374, file 433-3-1, Vol 4, letter 433-3-1 (DPR), from R.V. Dodd, DPR, to AOC Directors of Public Relations, dated 4 December 1946 refers. The sole exception to the decision to release women from the military was nursing sisters, who were retained to provide medical assistance.
} 
operations. Airborne and amphibious operations will be the rule rather than the exception. All forces must be mobile, and sufficient air transport must be available to move them by air. ${ }^{, 37}$

These considerations implied that the RCAF had to equip and plan to work with the other services in order to provide combined war-fighting capabilities in the close air support and air transport roles. Close air support involved the air force in providing fire support to army troops on the move or in a defensive position and required the integration of army and air force operational plans in order to achieve the desired effect and to avoid casualties to friendly troops. For this type of mission, the air force was in a supporting not leading - role. Another example of how the RCAF was required to consider the requirements of the other services was the need for aircraft capable of delivering airborne troops. Once again, these missions placed the air force in a support role rather than as the direct means of engaging an enemy force.

During the deliberations of the Organization Committee, there is evidence that air force planners acted in good faith to provide support to the other services. As indicated at Table 1, the proposed composition for Auxiliary Squadrons included eight fighterbomber squadrons suitable for close air support missions. The Regular RCAF was slated to have an additional two such squadrons, which resulted in almost one quarter of the postwar air force (ten of 44 proposed squadrons) providing direct support to army operations. For the transport role, the Regular RCAF was to have three squadrons, which, depending on the type of aircraft used, could serve as airborne troop carriers. Another example of the Organization Committee's willingness to support the other

\footnotetext{
${ }^{37}$ LAC, RG 24, Vol 5224, file S-19-78-71, Vol 3, memorandum S.19-7-71 (Plans F), entitled "Paper on Post War Organization of the R.C.A.F.", dated 24 March 1945.
} 
services was the inclusion of two flying boat squadrons for the regular RCAF, operating in support of the navy. At least originally, air force planners sought to dedicate a significant portion of its postwar strength to supporting the other services.

The RCAF was to be organized along regional lines. Initial plans had RCAF Headquarters and an Air Service Command Headquarters located in Ottawa. Air Command Headquarters were located in Vancouver (Western Air Command, responsible for British Columbia and Yukon Territories), Regina (No. 2 Air Command, responsible for Alberta, Saskatchewan, Manitoba, Northwest Territories and northwest Ontario), Toronto (No. 1 Air Command, responsible for the remainder of Ontario and Quebec) and Halifax (Eastern Air Command, responsible for the Maritime provinces). Under the Air Service Command there were to be four Wings, which were to be co-located with the regional command headquarters, consisting of an equipment depot, repair depot, and a construction and maintenance unit. ${ }^{38}$ Figure 1 depicts the initial postwar command structure.

Inexplicably, the distribution of Regular and Auxiliary Squadrons by the Post War Organization Committee would have resulted in Western Air Command having no Regular RCAF and three Auxiliary squadrons, No. 2 Air Command having three Regular RCAF and 8 Auxiliary squadrons, No. 1 Air Command having five Regular RCAF and 13 Auxiliary squadrons, and Eastern Air Command having five Regular RCAF and four Auxiliary Squadrons. ${ }^{39}$ While in later years the regular RCAF attributed the requirement to locate much of its fighter strength in the east on the need to protect large population

\footnotetext{
${ }^{38}$ LAC, RG 24, Vol 5226, file S-19-7-71A, Vol 1, Post War Organization Committee Minutes of Meeting No. 18 held on the $7^{\text {th }}$ September, 1944, at 1930 hours, Annex B, p. 3.

${ }^{39}$ Ibid.
} 


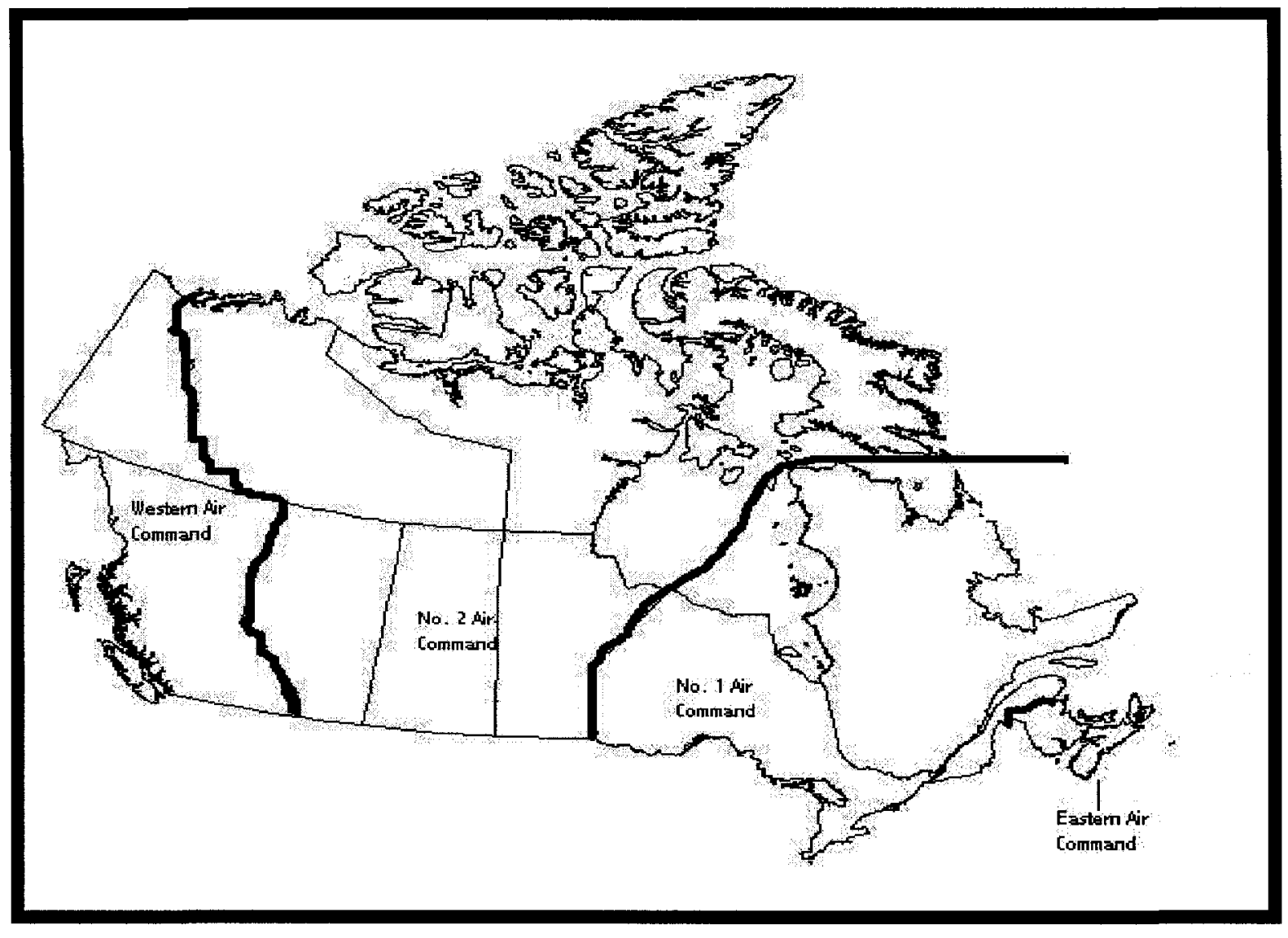

and industrial centres, this kind of reasoning was not present for the Organization Committee. It is not known why the committee chose not to locate any Regular RCAF squadrons west of Manitoba. The committee was aware of the threat appreciations identifying the Soviet Union as a potential enemy, yet did nothing to position the better trained regular RCAF where it could be involved in protecting western Canada. In addition, while ensuring that the political need to spread Auxiliary Squadrons across the country was satisfied, the Organizing Committee failed to take such political concerns under consideration when proposing locations for regular RCAF squadrons. This should be viewed as an error and unlikely to be endorsed by politicians aware of the requirement 
to spread the economic boost given by the presence of a federal organization across the country. Another indication that such political awareness was limited was demonstrated by assigning a Command Headquarters to British Columbia, with just three Auxiliary Squadrons, but none to Quebec, Canada's second most populous province and the location of the second highest number of Auxiliary Squadrons, with six.

The ability to plan was one of the most critical factors to the development of an efficient and effective air force and emphasizes the importance of work of the Post War Organization Committee. The committee recommended that postwar planning be centred at RCAF Headquarters under a Director General of Plans, who would report to the Vice Chief of the Air Staff. There were to be three Sections, responsible for Joint and Combined Plans (Plans 1), Operational Plans (Plans 2) and Training Plans (Plans 3). Each of these three section heads would have two staff officers to support activities. At the Command level, there was a small Plans cell under the Senior Air Staff Officer. Figure 2 depicts this proposed planning organization and where it was situated in the overall RCAF headquarters.

For a 30,000-strong regular force, plus another 65,000 personnel in the Auxiliary and Reserve forces, such a planning organization of ten personnel was marginally adequate. Given that the postwar air force would be adapting to peacetime roles in a changing geopolitical environment concurrent with technological advances such as jet propulsion aircraft and new weapons, a staff of three (Plans 2 plus the two subordinate officers) would be hard pressed to keep operational plans up to date and relevant for the entire RCAF. The same could be said of Plans 1 (Joint and Combined), which would have been responsible for planning activities associated with air force operations 


\section{Figure 2: Initial Postwar Plans Organization Proposal}

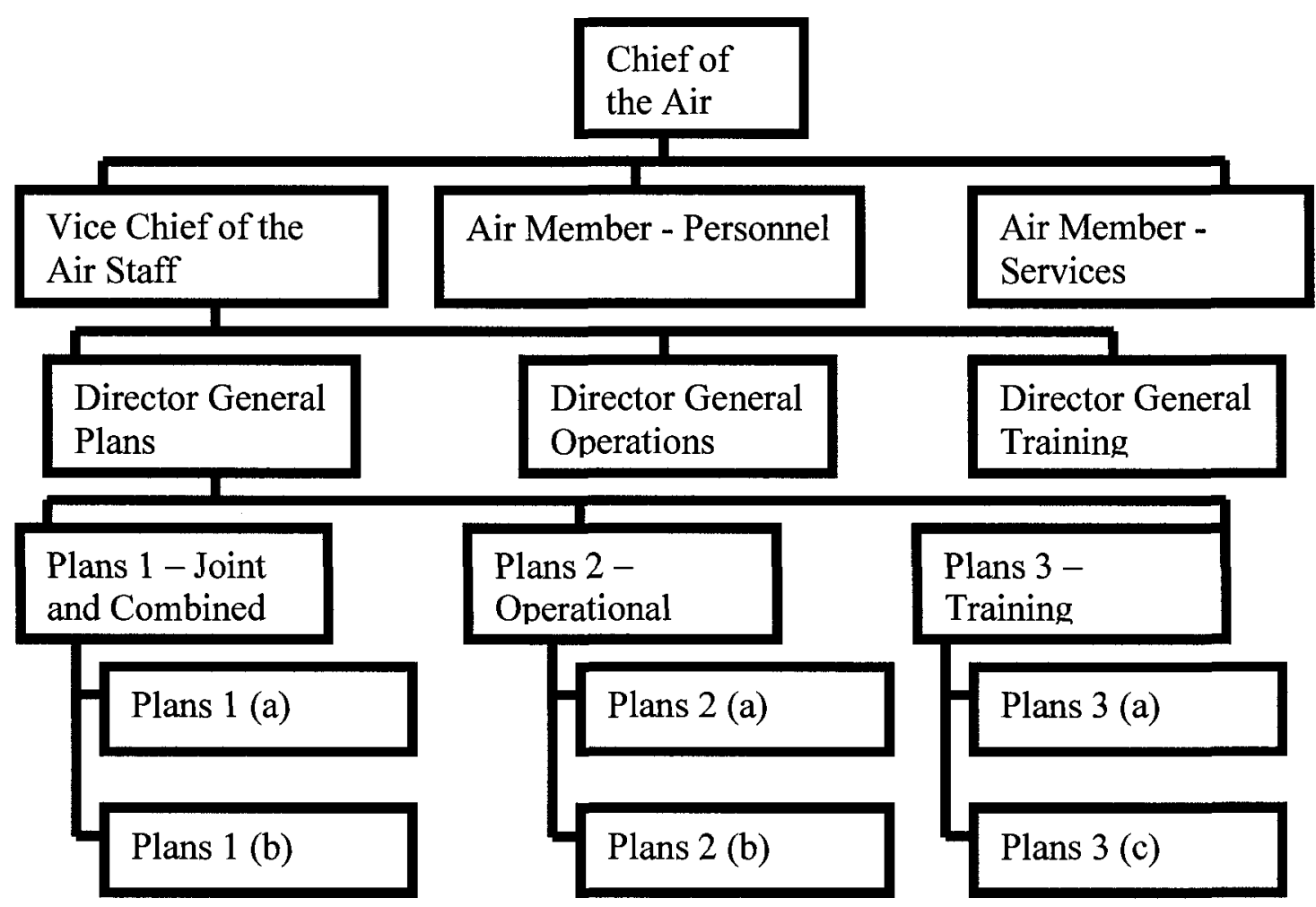

involving the Canadian Army and Navy as well as those involving collaboration with other nations. Plans 3 (Training) would also likely have difficulty keeping up with its responsibilities with only three persons, since it would have been in charge of developing plans for instruction on a wide range of different aircraft types and roles (close air support, transport, maritime support, fighter, etc) and integrating aircraft with new technology into the air force. Despite these criticisms of the resources intended to fulfil the planning role at air force headquarters, the grouping of planning activities under the categories of joint and combined, operational and training provides some insight into the range of responsibilities that fall under the general heading of "plans". 
With respect to its organizational placement, the positioning of the Director General Plans directly under the proposed position of Vice Chief of the Air Staff speaks to the importance and influence given to this activity. With such a reporting relationship, planners would have access to the highest level of decision makers within the RCAF and likely be able to influence evolving policy. It also would be well placed to provide input into other air force activities, such as procurement and overall RCAF personnel requirements. However, as events later turned out, a lower than expected personnel ceiling meant that many of the projected organizational positions never came to pass, including those of Vice Chief of the Air Staff, Director General Plans, and the Joint and Combined, Operational and Training Plans.

The Post War Organization Committee sought to establish relatively large squadrons (up to 18 aircraft each) with wartime vintage aircraft as initial inventory for postwar squadrons. This included such wartime favourites as the Spitfire, Mustang and Mosquito. All proposed operational aircraft were propeller driven, which were being technologically bypassed by the jet propulsion aircraft introduced at the end of the war. Given that pre-war RCAF squadrons sometimes had as few as four aircraft ${ }^{40}$ and a total inventory of 270 aircraft of 20 different types, this proposal for 727 aircraft ${ }^{41}$ would have been welcomed by the postwar air force. Another positive aspect of the committee's recommendations is that it sought to preserve a multi-disciplinary force: the proposed aircraft allocation would fulfil the full range of tactical, operational and strategic tasks, from reconnaissance to combat to transport, in support of army, navy and air force roles.

\footnotetext{
${ }^{40}$ Douglas, op. cit., pp. 148-150.

${ }^{41}$ LAC, RG 24, Vol 5226, file S-19-7-71A, Vol 1, Post War Organization Committee, Minutes of Meeting No. 11, held $8^{\text {th }}$ August, 1944, at 0930 hours and file S-19-7-71A, Vol 1, Post War Organization Committee Minutes of Meeting No. 18 held on the $7^{\text {th }}$ September, 1944, at 1930 hours, Annex B, pp. 7-12.
} 
Table 2 provides an overview of the committee's recommendation for the distribution of resources.

\section{Table 2: Proposed Postwar Aircraft Distribution ${ }^{42}$}

\begin{tabular}{|c|c|c|c|c|}
\hline Type of Sqn & Types of Aircraft & Number of Sqns & Aircraft Per Squadron & $\underline{\text { Total }}$ \\
\hline Fighter & $\begin{array}{l}\text { Spitfire } \\
\text { Mustang } \\
\text { Typhoon }\end{array}$ & $\begin{array}{l}2 \text { Regular } \\
9 \text { Auxiliary }\end{array}$ & 18 & 198 \\
\hline Fighter Bomber & Mosquito & $\begin{array}{l}2 \text { Regular } \\
9 \text { Auxiliary }\end{array}$ & 18 & 198 \\
\hline Medium Bomber & Ventura & $\begin{array}{l}2 \text { Regular } \\
9 \text { Auxiliary }\end{array}$ & 16 & 176 \\
\hline Very Long Range & Liberator & 4 Regular & 15 & 60 \\
\hline Flying Boat & Canso & 2 Regular & 15 & 30 \\
\hline Transportation & $\begin{array}{l}\text { Liberator } \\
\text { Dakota }\end{array}$ & 3 Regular & 15 & 45 \\
\hline Photo Survey & $\begin{array}{l}\text { Anson } \\
\text { Mitchell }\end{array}$ & 1 Regular & $\begin{array}{c}16 \\
4\end{array}$ & 20 \\
\hline
\end{tabular}

The RCAF's Post War Organization Committee concluded its report with the observation that the purpose of the document was "to provide a basis for discussion" and that it "was not intended to be complete or final". The report also noted that the cost of the plan had not as yet been calculated and that once estimates were completed there might be a requirement for "considerable revision". ${ }^{43}$ These words proved to be prescient.

In 1944, the RCAF also began planning for requirements in postwar Europe. Preliminary plans called for four heavy bomber squadrons, four fighter squadrons and

\footnotetext{
${ }^{42}$ Ibid., and file HQS 19-7-71A, Vol 1, Air Post War Organization Committee, Meeting 5, held 27 June 1944 , at 0930 hours.

${ }^{43}$ LAC, RG 24, Vol 5226, file S-19-7-71A, Vol 1, Post War Organization Committee Minutes of Meeting No. 18 held on the $7^{\text {th }}$ September, 1944, at 1930 hours, Appendix B, p. 13.
} 
three transport squadrons to remain overseas after the end of the war. ${ }^{44}$ The Secretary of State for Dominions Affairs in London was informed of this, ${ }^{45}$ with the caveat that there was no guarantee how long such an occupation force would be provided in light of political pressures that could be anticipated about demobilizing troops soon after the war. The retention of these squadrons in Europe would also rely upon whether Canada was provided with a role as an occupying force in Germany. ${ }^{46}$

These postwar planning activities were likely doomed to fail from the start. Indeed, none of the recommendations by the Post War Organization Committee was implemented. In designing the size, composition and organization of the proposed air force, the Organizing Committee, comprising just five members, took only four months during 1944 to complete their work. The process was limited in scope because of personnel and time constraints, and the wartime RCAF was having difficulty understanding how different the peacetime environment would be. There was also a lack of realism on behalf of the committee. Since the committee mainly consulted only within the air force, it was isolated from sources that could have provided a more balanced view of what the future may hold. In the end, since external political, economic and social considerations were only marginally considered, RCAF plans were destined to be questioned once they came before the government.

\footnotetext{
${ }^{44}$ LAC, RG 24, Vol 6172, file 15-48-8, memorandum TS. 15-48-8 (D/AMAS Plans) 23 August 1944. While not identified as such, these 11 squadrons must have been considered as part of the overall RCAF plan for 44 postwar squadrons, since otherwise the air force would have been in a position of expanding over its wartime establishment once the peace had been obtained.

${ }^{45}$ While RCAF units were under the direction of the Canadian government, Canada had traditionally kept the British government informed on defence issues. For detailed discussion concerning RCAF policies in relation to the British and the Royal Air Force, see Greenhous et al, op. cit., Chapters 1-3.

${ }^{46}$ LAC, RG 24, Vol 6172, file 15-48-8, telegram from Secretary of State for External Affairs, Ottawa to Secretary of State for Dominion Affairs, London, 9 January 1945.
} 


\section{The Evolving Perception of the Security Environment}

The nature of the threat to postwar Canada continued to be a topic of discussion within the inter-governmental Post Hostilities Problems Working Committee. This committee was aware that a British threat assessment had concluded that there would be no immediate danger posed to Great Britain. However, in place of the pre-war belief in Britain that there would be a ten-year period before conflict, ${ }^{47}$ this document concluded that planning for a two-year window of peace was more prudent. This led to a British decision that air defences had to be capable of expanding to wartime strength within two years. ${ }^{48}$ Hume Wrong, the chairman of and Department of External Affairs representative to the Post Hostilities Problems Working Committee, was not willing to concede that such a level of readiness was required in Canada. He argued that "at the worst there might follow a period of exhaustion which might last a decade during which Canadian defence problems, aside from problems of maintenance, would be practically dormant. At the best, during this decade or so, an effective system of maintaining security would come into being, and the specific part of Canada in it would become clear." Initially included in the committee minutes, but later deleted, was the statement that "[a]t present it seemed impossible to suggest a military policy for Canada to pursue

\footnotetext{
${ }^{47}$ In 1919, the British Treasury Board, with support from the government, directed the military to assume that the British Empire would not take part in any major conflicts for the next ten years as a means of controlling spending. In 1928, Winston Churchill, as Chancellor, made it a "rolling" ten year rule, renewed on an annual basis. Following the Japanese invasion of China in 1932 and the departure of Germany from a Geneva disarmament conference in 1933, this policy was cancelled. David Reynolds, Britannia Overruled - British Policy and World Power in the $20^{\text {th }}$ Century, (New York: Longman, 1991), p. 115 refers.

${ }^{48}$ LAC, RG 24, Vol 20347, file 952.013 (D57), P.H.P. (44) 20 (Final), 19 May 1944.
} 
after the war. One could only reach negative conclusions, such as that the danger of attack on Canada from outside was negligible until 1955 or so at any rate."

In its final report on postwar Canadian-American defence relations, the Post Hostilities Problems Working Committee came to some conclusions supporting an enhanced RCAF role. Asserting that the Allies would maintain larger forces than before the war, the Committee argued that, in addition to considering traditional threats from sea borne attack, "[a]dequate protection against air-borne attacks ... has become an essential part of North American defence." Specific mention was made of such threats from the north, northeast and northwest, which indicates that the Soviet Union was already perceived as a potential adversary after the war. Additional recommendations included maintaining larger Canadian armed forces than in the pre-war period and the retention of the Permanent Joint Board on Defence. ${ }^{50}$

This drift towards a closer Canadian-American defence relationship was paralleled by an increasing tendency for Canada to exclude itself from Commonwealth plans. At a British-led meeting with Dominion representatives in June 1945 relating to "Security of the British Empire", the Canadian delegate declined to serve as more than an observer. The Australian participant stated that his country's security now depended more on the United States than on Great Britain, ${ }^{51}$ which also could have summarized the Canadian position. Air Vice Marshal Wilfred (Wilf) Curtis, who would become Chief of

\footnotetext{
${ }^{49}$ LAC, RG 24, Vol 20347, file 952.013 (D65), Minutes of the Twenty-Fifth Meeting of the Working Committee on Post-Hostilities Problems held on Monday, July $3^{\text {rd }}$, at 4:30 p.m. in Room 123 in the East Block, dated July $4^{\text {th }}, 1944$.

${ }^{50}$ C.P.H.P. (44) Report 5 (Revised Final), entitled "Post-War Canadian Defence Relationship with the United States: General Considerations", 26 October 1944. This was attached to LAC, RG 24, Vol 20345, file 952.013 (D68).

${ }^{51}$ LAC, RG 24, Vol 20347, file 952.014 (D69), Minutes of Meeting of Dominion Representatives with Post-Hostilities Planning Staff held at 1, Richmond Terrace, at 1500 on Tuesday, $5^{\text {th }}$ June 1945, and attached P.H.P. 22/45, Comments on P.H.P. $22 / 45$ (draft).
} 
the Air Staff in 1947, supported this trend away from alignment with Great Britain to closer ties with the United States by noting that the standardization of equipment and supplies with the Americans made military sense. ${ }^{52}$ American equipment was more plentiful and readily available than British-made and, especially in relation to continental defence, the United States would be motivated to cooperate with Canada as a matter of self-interest.

The nature of the postwar military threat and the warning period before hostilities were enduring points of contention. Various government departments had differing opinions on these matters, as did senior officers in the army, navy and air force. The most prominent of these opposing viewpoints involved representatives of the Canadian Army and the RCAF, who disagreed in December 1944 over the inclusion of the assumption "that for several years, at least, there will be no direct military threat to North America" in a Post-Hostilities Problems Advisory Committee document being submitted to the War Cabinet. ${ }^{53}$ The army believed that there was no immediate threat, while the air force thought otherwise. The army's stance was strengthened by recent United States War and State Departments reports downplaying the possibility of a direct clash between the United States and the USSR. The American government now considered warfare between the countries unlikely, although there was an acknowledgment that there would be some degree of friction and political pressure between the two countries. ${ }^{54}$ If the

\footnotetext{
${ }^{52}$ LAC, RG 24, Vol 6170, file 15-48-1, Vol 2, memorandum S-15-48-1 (AMAS B.2), 31 July 1945, from W.A. Curtis, AVM, AMAS, to CAS.

${ }^{53}$ DND, DHH Vol 193.009 (D38), CSC Miscellaneous Memoranda, Nov/Dec 44, Vol 37, Extract from Minutes of the $308^{\text {th }}$ Meeting, Chiefs of Staff Committee, Held 29 Dec 44. The quoted comment was in reference to report CPHP (44) Report No. 5 (Final), by the Advisory Committee, Post-Hostility Problems, for which the Post Hostilities Problems Working Committee worked.

${ }^{54}$ The report of this position of the United States Government was received through Major-General Maurice Pope, the Chair of Canada's Joint Staff Mission in Washington. LAC, RG 24, Vol 6170, file HQ 15-48-1, Vol 1, Minutes of the Twenty-Sixth Meeting of the Working Committee on Post Hostilities
} 
Canadian government agreed that there was no immediate threat to North America, it was reasonable for this to be reflected in the peacetime size of the military.

The opinion of senior government representatives was another factor affecting the postwar size of the Canadian military. Prime Minister Mackenzie King would have a role in this debate and he favoured alternatives to a large military, indicating that "Canada could not depend on defence arrangements for their security, but must primarily rely on the establishment of an international system of security. Emphasis, therefore, should be placed on the Canadian contribution to the peaceful settlement of international problems. ${ }^{.55}$ King also wavered between supporting Canada's traditional linkage with Great Britain in matters of defence and acknowledgement of the importance of the United States to Canadian security. He often indicated a preference that the relationship with the British should continue to be a factor in Canadian defence planning.

Accordingly, the government, while acknowledging that the postwar military would have to be larger than before the war, was inclining towards participation in collective security arrangements as a means of limiting the scale of Canadian defensive arrangements. Such a position was in line with international developments, as shown by meetings outside of Washington at Dumbarton Oaks during the summer of 1944 between representatives of Great Britain, the United States, the USSR and China to discuss a new international organization in place of the League of Nations. These meetings resulted in

Problems held on Thursday, July $13^{\text {th }}$, at 4:30 p.m. in Room 123 in the East Block, dated July $14^{\text {th }} 1944$, refers.

${ }^{55}$ LAC, RG 24, Vol 6172, file 15-48-12, Minutes of the Sixth Meeting of the Advisory Committee on Post Hostilities Problems held on Friday, January $12^{\text {th }}$, in Room 123 in the East Block, dated $12^{\text {th }}$ January 1944. 
formal joint security proposals being released in October 1944, and eventually, the creation of the United Nations. ${ }^{56}$

Realizing that proposals for the creation of a world security organization would likely affect Canadian defence planning, the Chiefs of Staff took steps to consider them. On 1 March 1945, the Joint Planning Sub-Committee was directed to examine the military aspects of these initiatives. The sub-committee soon provided an assessment of the potential ramifications of such an organization for each of the services, which included the assertion that it would result in additional military commitments for Canada, not less. For the RCAF, these included patrolling the Northwest Atlantic and Northeast Pacific in conjunction with American and British forces, organization of "United Nations Bases" at Canadian military airfields, and maintenance of an integrated air force contingent under the control of the Security Council. ${ }^{57}$ International commitments were a means of providing for collective security, but the military did not consider these as a nocost panacea for Canadian defence problems.

Influenced by these considerations, the military's Joint Planning Sub-Committee sought to identify the strategic factors affecting Canada's postwar military requirements. This sub-committee began by articulating the reasons for Canadian military preparation, which were seen as including the "defence of Canadian Territory against attack", the "protection of Canadian trade and strategic routes", the "support of the World Security Organization", "co-operation with Commonwealth, United States or other forces with

\footnotetext{
${ }^{56}$ Stacey, op. cit., pp. 379-380.

${ }^{57}$ DND, DHH 193.009 (D41), CSC Miscellaneous Memoranda, Feb/Mar 45, Vol 40, T.S. 15-48-6, dated 15 March 1945, Minutes of Meeting of the Joint Planning Sub-Committee of the Chiefs of Staff Committee Held at RCAF Headquarters, Lisgar Building at 1400 hours, $12^{\text {th }}$ March, 1945.
} 
which Canada may be associated in the event of another war" and internal security. ${ }^{58}$ In considering the territorial threats, the Joint Planning Sub-Committee believed that despite the advances in military technology, Canada would remain a difficult country to invade. In what would become a recurring theme into the 1950 s, the sub-committee suggested that an enemy could stage a raid or landing, particularly by airborne troops, in coastal or northern areas for the purpose of establishing a base of operations. The purpose of such a force would be to divert resources from operations elsewhere. In the end, the subcommittee was not prepared to provide an estimate of how much time would pass before the next outbreak of war. It recommended instead that Canada establish a plan for military preparedness that would include adequate regular force personnel and defence industrial production. ${ }^{59}$

The evolving understanding of postwar security environment provided indications of future issues for Canadian defence. The growing importance of the United States to Canadian security was acknowledged, which corresponded with increasing recognition of a reduction of the role of Great Britain. Some were quicker to reach this conclusion than others. The threat from the Soviet Union was largely realized, as was the potential risk from air attack. These considerations reasonably should have influenced air force planners and they did to an extent. The problem, unfortunately, was in convincing the government that the threat required a measure of response from the air force, and this proved to be a difficult task.

\footnotetext{
${ }^{58}$ DND, DHH 193.009 (D41), CSC Miscellaneous Memoranda, Jun/Jul 45, Vol 42, Memorandum entitled "Strategic Factors Affecting Canada's Post-War Military Requirements", attached to HQS. 9072-5 (DMO\&P), 5 July 1945.

${ }^{59}$ Ibid.
} 


\section{Conclusion}

Such was the state of air force planning as the hostilities ended in Europe in May 1945. Prior to being prompted by the Post-Hostilities Problems Working Committee, the RCAF had been fully focused on fighting the war and not on the peace that would follow. The RCAF initiated planning for the postwar force with the establishment of the Post War Organization Committee, but this body was composed solely of air force personnel and largely operated independently of oversight from within or outside of the air force. At a time when the government was still debating the nature of the threat to Canada and focusing on the establishment of and participation in a multilateral security organization, the air force was making long term plans without seriously considering the political, economic and social environment. This no doubt was a major factor in the resulting RCAF plan for a 44-squadron peacetime establishment, comprising 28 Auxiliary and 16 Regular squadrons, which had no foundation in the realities of the time. Although the RCAF finalized its report on postwar organization in September 1944, the Cabinet Defence Committee did not ask about postwar plans from the three services until August $1945 .^{60}$ There is no indication that the government knew of the nature or contents of air force plans before this.

This first attempt at postwar planning by the RCAF must be viewed as a failure. No effort was made to convince Canadian politicians of the need for a substantive postwar establishment, in part because of the lack of political engagement or consultation by the air force. The RCAF provided no substantive justification for a large peacetime force and the manner in which the RCAF treated financial considerations is reflective of a 
wartime mentality in which the air force essentially got whatever it wanted. Pre-war RCAF budgets were limited and the government had not provided any guidance to suggest that this would change in the postwar period. Air force planners failed to consider that there would be high demands upon the postwar economy, beyond acknowledgement that their plan might undergo "considerable revision" by the government. As a result of this poor planning, the RCAF failed to achieve a single goal it established; none of the recommendations for size, role, or composition of the air force was adopted.

It is difficult to come to any conclusions about the level of professionalism shown by RCAF planners. While the postwar plan and the process used to develop it were badly flawed, the RCAF was still heavily engaged in fighting a war and had to give that the highest priority. Since no fulltime staff existed to plan for after the war, an ad hoc committee was formed and this showed in the results. To their credit, these planners exhibited the ability to consider not just air force requirements, but also those of the army and navy. The resources they intended to devote to support roles for the other services were significant; out of a total of 44 squadrons, 15 were tasked to support the army and navy in different roles. This is not the behaviour of an organization acting solely to promote its own interests. Yet, since the plans were not implemented, the motivation and organizational interests behind them are not easily assessed. Any insights into the professional nature of the RCAF will have to wait.

Another shortfall of the military planners is that they did not have a clear understanding of the future security environment. Basic security issues had to be

\footnotetext{
${ }^{60}$ LAC, RG 2, Vol 2748, Cabinet Defence Committee Conclusions, Vol 1, Minutes of Cabinet Committee on Defence Questions, August 13, 1945, at 2:30 p.m. in Privy Council Chambers, para 1, p.1.
} 
resolved, including what security organizations Canada would participate in, whether the close defence relationship with the United States established during the war would continue and how pre-war defensive arrangements with the British Commonwealth would be affected. The postwar RCAF role in domestic security was also unresolved. Technological advances posed new security challenges for Canada and what this meant to the army, navy and air force was unknown. Moreover, the RCAF needed to develop and formalize a peacetime planning process in order to operate effectively in this new environment. Many of these issues came to a head in the period immediately following the cessation of the European war. 


\section{CHAPTER TWO}

\section{"A VERY BITTER STAGE":}

\section{POSTWAR RETRENCHMENT, 1945-1946}

Senior RCAF leadership undoubtedly foresaw a bright and vibrant postwar future for the air force. The air force had grown to 48 overseas squadrons during the war and had an important role in anti-submarine, transport, close air support and bombing operations. This contributed to an ambitious postwar plan for 16 Regular RCAF squadrons and another 28 Auxiliary Squadrons. To staff this, authority was sought for a total air force of 95,000 personnel: 30,000 in the Regular Force, 15,000 in the Auxiliary, and 50,000 in the Reserve. As events turned out, much of the initial air force's postwar planning efforts were for naught, as the government focused more on re-building the postwar economy and improving conditions for wider Canadian society than on the requirements for the army, navy and air force. This was influenced by the government's view that significant postwar military expenditures were somewhat unnecessary or, at most, a lower priority than social programmes. James Eayrs has described how the government sought to keep military spending under control, as demonstrated by Prime Minister Mackenzie King's stated desire to "get back to the old Liberal principles of economy, reduction of taxation, anti-militarism". ${ }^{1}$ David Bercuson's biography of Minister of National Defence Brooke Claxton reinforced this view, noting that Mackenzie King's government "was firmly committed to drastic cuts in the defence

\footnotetext{
${ }^{1}$ James Eayrs, In Defence of Canada - Peacemaking and Deterrence (Toronto: University of Toronto Press, 1972), p. 92.
} 
budget to free up funds for family allowances, veteran's benefits, and other new social programs". ${ }^{2}$

This chapter will focus mainly on planning and related developments during the period immediately following the end of the Second World $\mathrm{War}^{3}$, spanning from September 1945 to the end of 1946 . This review will exclude those activities associated with the development of the Basic Security Plan, which will be addressed in the next chapter. During this time, the air force demobilized, established terms of service and recruited for a peacetime force, and laid the groundwork for the postwar RCAF. As part of this examination, issues of postwar retrenchment and the state of RCAF policy, plans and doctrine will be explored. This era provided many serious challenges for the RCAF and provided little basis for the air force leadership and members to anticipate the significant growth in the role, size and prestige enjoyed by the RCAF in the years that followed.

\section{Postwar Government Direction}

In June 1945, with the European war now over and plans being developed for the conclusion of hostilities with Japan, a meeting of the Ministers of National Defence ${ }^{4}$ was called with the Chiefs of Staff to discuss postwar defence forces and coordination

\footnotetext{
${ }^{2}$ Bercuson, op. cit., p. 154. Stacey, op. cit., pp. 404-405, provides discussion on the economic problems encountered postwar because of credit shortages in Europe and a Canadian trade imbalance with the United States. J. Douglas Gibson, ed., Canada's Economy in a Changing World (Toronto: Macmillan, 1948) provides a period description of the anxiety over the postwar economy within Canada.

${ }^{3}$ Although hostilities with Japan on 15 August 1945 ended after the dropping of the nuclear bombs on Hiroshima and Nagasaki, the formal signing of the unconditional surrender agreement did not take place until 2 September 1945.

${ }^{4}$ At this time, political leadership of the military was split between the Minister of National Defence (A.G.L. McNaughton), the Minister of National Defence for Naval Services (D.C. Abbott) and the Minister of National Defence for Air (Colin Gibson). Postwar, in December 1946, these three positions were converted back to a single Minister of National Defence.
} 
between the services. On behalf of the RCAF, the Chief of the Air Staff, Air Marshal Robert Leckie, presented the Post War Organization Committee's recommendation for a Regular RCAF of 30,000, an Auxiliary Force of 15,000 and a Reserve Force of 50,000. Foreseeing an annual attrition rate of around 3,000 from the Regular Force, Leckie believed that sufficient volunteers could be recruited to satisfy personnel requirements, so he declined to support any call for universal military service. He also provided a total cost estimate of $\$ 78.5$ million, excluding equipment costs, which were not identified. In comparison to the other services, the Canadian Army sought a total of 281,684 personnel (55,788 Active Force, 177,396 Reserve Force, 48,500 Training Force) at a cost of $\$ 162$ million for operations and $\$ 37$ million for equipment. The Royal Canadian Navy requested a peacetime force of 20,000 active service personnel and another 20,000 personnel for the Naval Volunteer Reserve, with a rough cost estimate of $\$ 50$ million annually. The Minister of National Defence for Naval Services prophetically suggested that the combined costs for the services, at $\$ 327.5$ million plus some equipment costs, "seemed high". The Ministers decided to ask the Chiefs of Staff to prepare briefings based upon these proposals for eventual consideration by Cabinet. $^{5}$

Concurrent with the development of postwar plans, effort went into planning for the repatriation and demobilization of troops following the end of the fighting. In March 1945, the Cabinet War Committee was informed that, with due consideration for operational requirements, personnel would be demobilized at the "maximum rate possible", with the RCAF targeting 10,000 personnel monthly to be returned to civilian

\footnotetext{
${ }^{5}$ DND, DHH 112.3M2009 (D90), Minutes of a Special Meeting of the Ministers of National Defence and the Chiefs of Staff, held in the Defence Council Chamber at 1500 hours, $25^{\text {th }}$ June, 1945.
} 
life. $^{6}$ Near the end of August 1945, with hostilities now ending in both Europe and Japan, Leckie informed the Minister of National Defence for Air that time was required to prepare for the transition to a peacetime air force. He sought authority for a two-year Interim RCAF under the same terms and conditions as wartime service. This would consist of 30,000 men, 10,000 of which were for an overseas headquarters and occupational force, and 20,000 for operations within the Western Hemisphere. Leckie also expressed concern that, in the absence of a policy decision from the government regarding the nature and size of the future air force, the most experienced and capable service members would take their releases and resume civilian careers. ${ }^{7}$ Cabinet soon approved the establishment of an Interim Force from 1 October 1945 - 30 September 1947, for a Regular RCAF of 20,000, an Auxiliary of 15,000 and an Air Force Reserve of $50,000 .^{8}$

On 21 September 1945, the Cabinet Committee on Defence met and, with various demands upon the government's finances becoming more evident, directed the RCAF to further reduce its proposed strength - this time to $15,000 .{ }^{9}$ The army and navy received similar guidance about the need to reduce their postwar forces. Additional cabinet decisions in this period included direction that the RCAF was to maintain a photographic

\footnotetext{
${ }^{6}$ DND, DHH 193.009 (D41), CSC Miscellaneous Memoranda, Feb/Mar 45, Vol 40, Memorandum to Cabinet War Committee entitled "Re-allocation, repatriation, demobilization and re-establishment of Armed Forces on termination of European hostilities", 25 March 1945.

${ }^{7}$ LAC, RG 24, Vol 3316, file HQ 282-8-5, Vol 1, memorandum "Conditions of Service - Interim Post War Period", 24 August 1946, from AM Robert Leckie, CAS, to Minister.

${ }^{8}$ LAC, RG 24, Vol 5226, file S-19-7-71A, Vol 2, Post War Organization Committee, Minutes of Meeting No. 76 held $25^{\text {th }}$ August, 1945, at 1000 hours, and RG 24, 3316, file HQ 282-8-5, Vol 1, memorandum S.45-4-65 (D of P), 12 September 1945, from AM Robert Leckie to Minister.

${ }^{9}$ DND, DHH 112.1 (D52), Agenda of Meeting of the Cabinet Defence Committee, September 1945February 1946, memorandum from A.D.P. Heeney, Secretary, to Air Marshal Robert Leckie, 24 September 1945.
} 
capability to perform aerial surveys on behalf of the government ${ }^{10}$ and was to take over the servicing, communications and maintenance of the North West Staging Route from American forces, ${ }^{11}$ with the understanding that this last task would entail financing and manning above and beyond what was approved as part of the RCAF's budget and personnel ceiling. The surveying role was exactly the kind that the RCAF had hoped to avoid, as much of its pre-war mandate involved non-military tasks. These mapping and charting missions had contributed to the perception within the air force that they had been reduced to "bush pilots in uniform" during the pre-war. ${ }^{12}$

In addition to placing restrictions on manpower levels, the Cabinet Defence Committee provided direction on commitments for new equipment. At a meeting on 24 September 1945, Committee members were briefed on a Treasury Board document from 1 March 1945 that authorized the purchase of 70 four-engine transport aircraft at a cost of $\$ 52,500,000$. The RCAF had reviewed its requirements for transport aircraft following the termination of hostilities and proposed that the number of aircraft be reduced to 50 , with 12 to be delivered during 1946-47 and 19 additional aircraft delivered each of the succeeding two years. The Committee delayed until the next day to allow consultation with Minister of Munitions and Supply, C.D. Howe, when it was decided to allow the air force to place an order for the 12 transport airplanes for the following year. No firm commitment was permitted for the follow-on aircraft in the succeeding years. ${ }^{13}$ At least

\footnotetext{
${ }^{10}$ DND, DHH 112.1 (D52), Agenda of Meeting of the Cabinet Defence Committee, September 1945February 1946, memorandum entitled "Use of RCAF Photography for Civil Purposes", by A.D.P. Heeney, Secretary to the Cabinet, 12 October 1945.

${ }^{11}$ DND, DHH 112.1 (D52), Agenda of Meeting of the Cabinet Defence Committee, September 1945February 1946, memorandum S.19-23-1 (DOE), from Minister of National Defence for Air to the Cabinet, 15 September 1945.

${ }^{12}$ Douglas, op. cit., p. 91.

${ }^{13}$ LAC, RG 2, Vol 2748, Vol 1, Minutes of Cabinet Committee on Defence Questions, dated 24 September 1945, p. 2, para 3-4.
} 
in its transport role, the government provided the RCAF with sufficient support to begin replacing wartime equipment.

Despite the economies being forced upon the military, there was recognition within the government that the air force would have a major role in the future. While addressing the House of Commons on 4 October 1945, Minister of National Defence for Air Colin Gibson stated that:

No definite decision has yet been made as to the strength and composition of the post-war air force, as until the nature and extent of any commitment that we may have under international or regional arrangements have been determined it is obviously impossible to reach any final decision... While experiments and research are going on, we do not consider it advisable to commit ourselves to the purchase of large numbers of either fighters or bombers, but believe that we should continue for the present with those we have available... The production of the atomic bomb will ... have far reaching effects on the whole science of war, but whatever its effects may be upon the other services, I consider that it will undoubtedly increase the relative importance of air power. ${ }^{14}$

In December 1945, the Cabinet Defence Committee was informed that the American representatives on the Canada - United States Permanent Joint Board on Defence had recently proposed to open discussions on continuing collaboration in defence planning between the two countries. The Committee was asked for political direction on how joint defence plans could best proceed. Discussion led to the recommendation that Cabinet approve ongoing defence cooperation with the United States and that the Chiefs of Staff Committee, along with appropriate civilians officials, be made responsible for coordinating Canadian involvement in joint planning. ${ }^{15}$ This resulted in the Canadian military and their American counterparts drafting an update to

\footnotetext{
${ }^{14}$ Canada, House of Commons Debates, $2^{\text {nd }}$ Session 1945, I, 765, quoted from James Eayrs, In Defence of Canada - Growing Up Allied (Toronto: University of Toronto Press, 1980), pp. 86-87.
} 
the Canada-United States Defence Plan, ABC-22, which had been put in place in July 1941 as part of wartime measures. ${ }^{16}$ The development of this new plan played a central role in the growth of the postwar RCAF and is the central focus of Chapter Three.

Despite the government decision to limit the RCAF Regular Force to 15,000 personnel, the air force continued its attempts for a larger organization. Air force planners noted that the United Nations Charter, Article 45, indicated that in "order to enable the United Nations to take urgent military measures, Members shall hold immediately available national air force contingents for combined international enforcement action". They also observed that technological advances had brought about atomic energy and "homing and guided missiles as offensive weapons of tremendous destructive power". Although willing to reduce their preliminary postwar estimates, the air force still argued for a Regular Force of 20,000, an Auxiliary Force of 10,000 and a Reserve Force of 25,000 to perform their full range of tasks. An additional 3,500 personnel were needed to maintain the North West Staging Route. ${ }^{17}$ This plan called for the use of existing aircraft for up to five years before being replaced, organized into 10 squadrons and eight composite flights for the Regular Force, and an initial 19 squadrons followed later by another nine squadrons for the Auxiliary Force. ${ }^{18}$

While foreseeing the effectiveness and implications of technologically advanced weapons, the RCAF also began to recognize the economic and political realities in postwar Canada. This meant that the air force was unlikely to obtain the financial

\footnotetext{
${ }^{15}$ LAC, RG 2, Vol 2748, Vol 1, Minutes of the Tenth Meeting of the Cabinet Defence Committee, held in Room 568, House of Commons, on Tuesday 4 December 1945, p. 2, paras 3-4.

${ }^{16}$ Ibid., CSC 101-1, 21 December 1945, from A.D.P. Heeney, Secretary to Cabinet to Vice-Admiral J.C. Jones, Acting Chair, Chief of Staff Committee.

${ }^{17}$ LAC, RG 24, Vol 5224, file S-19-7-71, Vol 1A, Report of the Post-War Planning Committee, Proposed Post-War Plan for the Royal Canadian Air Force, revised to 1 December 1945.
} 
support necessary to replace wartime aircraft with new and more technologically advanced equipment, so RCAF leadership and planners simply avoided asking for such expenditures and made do with what they had. This was an early indication that the air force was capable of managing its own expectations until such time as circumstances were more favourable. In disputing government direction in the area of personnel levels, the RCAF showed that it was willing to represent its own interests. This balance between obeying the government while expressing organizational self-interests would be an enduring challenge for the air force.

On 19 December 1945, Cabinet again asserted that the RCAF should plan for a force of 15,000. A final air force submission to the government on 6 February 1946 provided three options, demonstrating a willingness to engage in contingency planning. The first, called Scheme A, was the same as that previously proposed: 20,000 Regular Force personnel, 10,000 Auxiliary personnel and 25,000 Reservists. There would be ten Regular Force operational squadrons (three bomber reconnaissance, three transport, and one each for photography, fighter reconnaissance, fighter bomber and air observation) and eight composite flights. The Auxiliary would have 19 squadrons (12 fighter, five fighter-bomber and two fighter-reconnaissance) under this scheme. The total estimated cost for this plan was $\$ 69.4$ million. Scheme B was for 16,100 Regular Force personnel, including 8 Regular Force squadrons, with the deletion of a bomber-reconnaissance squadron and a transport squadron from the number proposed under Scheme A, plus the eight composite flights. The Auxiliary would have 15 squadrons, with the deletion of two fighter and two fighter-bomber squadrons. The supporting and training

\footnotetext{
${ }^{18}$ LAC, RG 24, Vol 5224, file S-19-7-71, Vol 1A, Report of the Post-War Planning Committee, Proposed Post War Plan for the Royal Canadian Air Force, revised to 1 December 1945.
} 
establishments were also reduced to reflect the cuts to the Regular and Auxiliary Forces. The overall Auxiliary Force would be trimmed down to 4,500 and there would be 10,000 Reservists under Scheme B. The cost for this plan was estimated at $\$ 59.15$ million. Scheme C involved the creation of an RCAF Regular Force of 15,000, with seven operational squadrons and eight composite flights, which would be achieved by eliminating the three bomber-reconnaissance squadrons proposed in Scheme A altogether and associated cutbacks. The Auxiliary Force strength and squadron organization and Reservist strength would be as outlined in Scheme B. The cost for this plan was $\$ 49.85$ million. The relative strengths, components and costs of these three proposals are shown in Table 3.

Minister of National Defence for Air Gibson expressed concern with the adoption of Schemes B and C, since either plan would have resulted in the elimination of a significant amount of the combat power. Scheme A had 24 squadrons suitable for combat, five of which were Regular RCAF. Scheme B had 19 combat squadrons, which included four Regular RCAF squadrons. Scheme $\mathrm{C}$ had 17 combat squadrons, with the Regular RCAF contributing only two squadrons. Despite these concerns, Gibson agreed that in order to comply with government direction, the elimination of the bombers was the easiest means of achieving the manpower reduction due to the large establishment required to support them. ${ }^{19}$ He recommended to Cabinet that Scheme B be adopted. ${ }^{20}$

\footnotetext{
${ }^{19}$ DND, DHH 181.009 (D4987), H.Q. S.19-7-71, "Proposals for Post War Royal Canadian Air Force", January 1946, from Minister to Cabinet.

${ }^{20}$ DND, DHH 112.1 (D52), Agenda of Meeting of Cabinet Defence Committee, September 1945 February 1946, letter entitled "Cabinet Meeting of February $6^{\text {th }}-$ Air Force: Composition of Postwar Establishments", from A.D.P. Heeney, Secretary to the Cabinet, to Air Marshal Robert Leckie, Chairman, Chiefs of Staff Committee, 8 February 1946.
} 
Table 3: Schemes A, B and C

\begin{tabular}{|c|c|c|c|}
\hline Scheme & $\mathrm{A}$ & $\mathrm{B}$ & $\mathrm{C}$ \\
\hline Personnel & $\begin{array}{c}\text { 20,000 Regular } \\
\text { 10,000 Auxiliary } \\
\text { 25,000 Reservists }\end{array}$ & $\begin{array}{c}\text { 16,100 Regular } \\
\text { 4,500 Auxiliary } \\
\text { 10,000 Reservists }\end{array}$ & $\begin{array}{c}\text { 15,000 Regular } \\
\text { 4,500 Auxiliary } \\
\text { 10,000 Reservists }\end{array}$ \\
\hline $\begin{array}{l}\text { Regular RCAF } \\
\text { Squadrons }\end{array}$ & $\begin{array}{c}10: \\
3 \text { bomber } \\
\text { reconnaissance } \\
3 \text { transport } \\
1 \text { photographic } \\
1 \text { fighter } \\
\text { reconnaissance } \\
1 \text { fighter bomber } \\
1 \text { air observation }\end{array}$ & $\begin{array}{c}8: \\
2 \text { bomber } \\
\text { reconnaissance } \\
2 \text { transport } \\
1 \text { photographic } \\
1 \text { fighter reconnaissance } \\
1 \text { fighter bomber } \\
1 \text { air observation }\end{array}$ & $\begin{array}{c}7: \\
3 \text { transport } \\
1 \text { photographic } \\
1 \text { fighter } \\
\text { reconnaissance } \\
1 \text { fighter bomber } \\
1 \text { air observation }\end{array}$ \\
\hline $\begin{array}{c}\text { RCAF } \\
\text { Auxiliary } \\
\text { Squadrons }\end{array}$ & $\begin{array}{c}19: \\
12 \text { fighter } \\
5 \text { fighter bomber } \\
2 \text { fighter } \\
\text { reconnaissance }\end{array}$ & $\begin{array}{c}15: \\
10 \text { fighter } \\
5 \text { fighter bomber }\end{array}$ & $\begin{array}{c}15: \\
10 \text { fighter } \\
5 \text { fighter bomber }\end{array}$ \\
\hline $\begin{array}{c}\text { Total } \\
\text { Squadrons }\end{array}$ & 29 & 23 & 22 \\
\hline Total Cost & $\$ 69.4$ million & $\$ 59.15$ million & $\$ 49.85$ million \\
\hline
\end{tabular}

On 8 February 1946, the government finally gave formal support to Scheme B, as supported by the Minister. In recognition of the major downsizing from the initial postwar plan for a force of 30,000 to the approved 16,100 , the formal role of the RCAF changed from that of maintaining "an air force in strength and readiness to uphold national policies and interests and to guard Canada from air attack" ${ }^{21}$ to one of providing "a well balanced nucleus of highly proficient personnel, which is capable of rapid, efficient expansion in the event of an emergency". ${ }^{22}$ In addition to the staffing level authorized under Scheme B, an additional 2,849 personnel and \$8 million was approved

\footnotetext{
${ }^{21}$ LAC, RG 24, Vol 5226, file S-19-7-71A, Vol 1, Post War Organization Committee Minutes of Meeting No. 18 held on the $7^{\text {th }}$ September, 1944, at 1930 hours, Appendix B, p. 2.
} 
by Cabinet for operation of the North-West Staging Route. ${ }^{23}$ A result of the governmentdirected cutbacks was that the planning structure identified at Figure 2 for a 30,000 strong air force was not implemented. No Vice Chief of the Air Staff organization was created, nor was there a Director General Plans. This was to have long term ramifications for the RCAF, which will be described later.

From the heights reached during Second World War, the RCAF was undergoing significant changes. As envisioned by Scheme B, the initial postwar RCAF was not designed as a combat capable force able to defend Canada, but was intended to serve simply as the basis for future mobilization. Its main role would be to retain a range of basic skills acquired during the war. The air force, at least for a period, would be incapable of mustering much of a response against an attacking force. However, since such an attack was not seen as imminent or even as a possibility for at least ten years, there was no requirement for a large standing air force. This state of affairs obviously was not what the air force wanted, but given the circumstances, it was a reasonable option for the government to select. This would soon change, as the perception of the threat to the security of Canada developed. The RCAF would be quick to take advantage of the opportunities presented.

The Postwar Canadian Security Environment

The contents of Scheme B were, for the most part, made public in a 28 February 1946 address by the Minister of National Defence for Air to the Empire Club of Toronto

\footnotetext{
${ }^{22}$ DND, DHH 181.004 (D44), Post War Plan for the Royal Canadian Air Force, April 1946, p. 1.

${ }^{23}$ DND, DHH, 112.1 (D52), Agenda of Meeting of Cabinet Defence Committee, September 45-February 1946, memorandum H.Q. S.19-7-71, entitled "Proposal for Operation of the North-West Staging Route by the Royal Canadian Air Force", from Minister to Cabinet Defence Committee, dated January 1946.
} 
entitled "Air Power in Canada". Gibson opened by praising the pre-war and wartime accomplishments of the RCAF. He spoke of the destructiveness of evolving weapons and the future role of the air force in providing both defensive and offensive capabilities, quoting American General H.H. Arnold on an air force's ability to be the first to engage an attacking force or to strike out at an enemy. ${ }^{24}$ Gibson fully acknowledged the critical role of air power in national security and was supportive of Canadian participation in international organizations to foster peace. When specifically referring to the RCAF, Gibson stated that "In no case can we afford to be without one". ${ }^{25}$ However, events associated with the demobilization and reduction of the RCAF were to expose a dichotomy between stated government policy and the actual level of support provided to the air force. Gibson's public statements about the nature and capability of Canadian air power were simply not based on the reality of the time, as shown by the government's decision to change the air force's role to "a well balanced nucleus of highly proficient personnel, which is capable of rapid, efficient expansion in the event of an emergency". ${ }^{26}$ This did not describe a force capable of attacking or striking an enemy. At most, the Minister of National Defence for Air's presentation can be viewed as intentions for the future.

Soon after receiving the government's support for Scheme B, Air Marshal Robert Leckie wrote to Sir Arthur Tedder, his Royal Air Force counterpart, describing the plan. Leckie expected criticism from other air forces for a Regular Force of 16,000 men with only eight squadrons, but insisted that this would provide the basis for future rapid

\footnotetext{
${ }^{24}$ DND, DHH 181.009 (D6488), "Air Power in Canada", address by Col. The Hon. Colin Gibson, M.C., M.P., Minister of National Defence for Air, to the Empire Club of Toronto, February $28^{\text {th }}$, 1946, p. 6 . ${ }^{25} \mathrm{Ibid}$.

${ }^{26}$ DND, DHH 181.004 (D44), Post War Plan for the Royal Canadian Air Force, April 1946, p. 1.
} 
expansion. He also outlined the intended aircraft distribution between the squadrons. Two bomber reconnaissance squadrons would be equipped with 12 Lancasters. Two transport squadrons would receive 12 Dakotas and 12 Liberators. Four Lancasters, eight Ansons and one Canso were designated for a Photographic squadron. The fighter reconnaissance squadron was allocated 12 Spitfires. Fifteen Mosquitoes were assigned for a fighter bomber squadron. An Air Observation squadron had 12 Austers for duties with the Army. There were also an unidentified number of composite flights for such duties as target towing and air rescue. Ten Auxiliary fighter squadrons and two Auxiliary fighter reconnaissance squadrons were to be given eight Spitfires and four Harvards each. The three Auxiliary fighter bomber squadrons were scheduled to receive eight Mosquitoes and four Harvards. ${ }^{27}$ This distribution of aircraft would have preserved a measure of combat capability for the RCAF, albeit based upon wartime technology. But Leckie was later not able to implement most of it.

In this correspondence to Tedder, Leckie did not mention his reasons for retaining the bomber role. Since each Lancaster had a crew complement of seven and needed a large maintenance team in support, the allocation of 12 Lancasters to two Regular RCAF squadrons represented a large manpower commitment in an air force limited to 16,000 . However, the RCAF's significant contribution to the bomber offensive during the Second World War likely played a role in Leckie's reluctance to eliminate bombers from the air force. Leckie concluded his correspondence to Tedder with a suggestion for "continuing and vigorous RAF-RCAF co-operation". ${ }^{28}$ This was contrary to the overall direction of the government, which was moving away from engagement with British defence

\footnotetext{
${ }^{27}$ DND, DHH 181.009 (D4987), letter from Air Marshal Robert Leckie to Sir Arthur W. Tedder, Marshal of the Royal Air Force, dated 12 February 1946.
} 
initiatives. Just ten days earlier, Cabinet declined participation in a British proposed "Commonwealth Route Squadron" that was to develop uniform techniques for the movement and supply of military forces. ${ }^{29}$ Here and on other occasions, Leckie appeared at times somewhat out of step or misinformed on details concerning planning activities for the postwar RCAF.

Another indication of the direction of Canadian defence policy was provided during a month-long meeting in London of Commonwealth Prime Ministers during April-May 1946. When the British Chiefs of Staff arranged for defence-related press speculation in the hope that this would sponsor some discussion at the meetings regarding Commonwealth defence, ${ }^{30}$ Prime Minister Mackenzie King declined to become engaged in this area. However, there was a general agreement between participants that defence had to be organized on a regional basis, with nations focusing on their own regions. And since any upcoming war would likely necessitate cooperation with the United States, delegates found that it would be reasonable for Commonwealth nations to pursue defensive arrangements with the Americans on their own terms. ${ }^{31}$ Given Canada's geographic proximity to the United States, the practicality of this would have been most obvious to Canadians. This situation and Canada's ongoing discussions with the United States about continuing wartime defence collaboration should have contributed to a growing realization in senior RCAF ranks that the air force's future laid in close ties with

\footnotetext{
${ }^{28}$ Ibid.

${ }^{29}$ DND, DHH 112.1 (D52), Agenda of Meeting of the Cabinet Defence Committee - September 1943 February 1946, Cabinet Document D-32, Memorandum to the Cabinet Defence Committee, entitled "Canadian Participation in Commonwealth Route Squadron", dated 2 February 1946.

${ }^{30}$ DND, DHH, 193.009 (D53), Box 1, 1946, Papers and Meetings, CGS - Copies of Memoranda, Chiefs of Staff Committee, Vol 56, June 1946, file number CSC 5-2. Vol 1, dated 19 June 1946. Attached to this document is a report, file number A. 439, from Frederic Hudd, Acting High Commissioner, Office of the High Commissioner for Canada, Canada House, London, dated 3 June 1946, p. 3.

${ }^{31}$ Ibid., pp. 3-4.
} 
American forces. Such developments would logically have come at the expense of traditional ties to the RAF, but this was not always the case, as colonial ties and the tradition of working before and during the war with the RAF proved difficult for some to overcome.

\section{Demobilization of the Wartime RCAF}

While RCAF planners were working to get approval for a peacetime establishment, the demobilization of the wartime air force carried on at a rapid pace. Within a few months of VE Day, only nine squadrons remained on active duty in Europe (instead of the 11 squadrons committed for an occupation force in August 1944), with five squadrons attached to the British Air Forces of Occupation in Germany and four bomber squadrons attached to the Royal Air Force's Striking Force. ${ }^{32}$ By the end of the year, this was reduced to a total of six squadrons overseas and these were disbanded by June $1946 .^{33}$ In Canada, by December 1945 , the RCAF was reduced to only four squadrons: No. 12 (Communication) Squadron, No. 124 (Ferry) Squadron, and No. 168 (Heavy Transport) squadron, all in Rockcliffe, and No. 164 (Transport) Squadron in Moncton. ${ }^{34}$ Plan B's intention of maintaining a fighter and bomber capability was completely ignored. Four months later, the Heavy Transport Squadron at Rockcliffe was also disbanded. The RCAF had gone from a wartime peak of 70 squadrons (with up to 48 serving as part of the RCAF Overseas and the remainder as part of the Home War

\footnotetext{
${ }^{32}$ LAC, RG 24, Vol 17666, file 045-7, Vol 2, RCAF Logbook - A Chronological Outline of the Origin, Growth and Achievement of the Royal Canadian Air Force, Air Historical Section, January 1949, p. 83.

${ }^{33}$ Ibid., pp. 84-85.

${ }^{34}$ Ibid., p. 84.
} 
Establishment) ${ }^{35}$ to only three Regular Force squadrons assigned to non-combat roles within ten months of the end of the war with Japan. The postwar RCAF suddenly had less fighting capability than even the pre-war air force, which had been considered inadequate. $^{36}$

Consequently, Gibson's words of February 1946 must be taken as a statement of intention for future RCAF capability and certainly not an accurate assessment of the air force's power at that time. The RCAF under Scheme B anticipated a force of more than 600 aircraft at a time when they had no combat-capable Regular or Auxiliary squadrons flying in Canada and those few squadrons left in Europe were soon to be disbanded. This directly speaks to the profound gap between air force plans and its capabilities, a state of affairs that was to exist for many years. It also demonstrated that the air force was politically and strategically ineffective in its dealing with the government. RCAF force structure and size were not reflective of organizational goals, which included fielding a multi-purpose, combat capable force.

Another example of air force ineffectiveness related to the retention of personnel for the postwar period. While as early as 1942 RCAF members had submitted requests for transfer to the permanent RCAF and enrolment in the postwar air force, there was reluctance on the part of the air force to come to any early decision on this matter. ${ }^{37}$ Forced finally to resolve this issue with the end of hostilities, in mid-September 1945 the RCAF developed a procedure for applying to the permanent force, which was meant to

\footnotetext{
${ }^{35}$ Greenhous, op. cit., p.40.

${ }^{36}$ At the beginning of the Second World War, the RCAF comprised 24 squadrons (eight regular force and 12 Auxiliary), most of which were under strength and equipped with old aircraft. One squadron had modern fighter aircraft. Greenhous, op.cit., p. 13. Following the postwar demobilization, the air force was reduced to three transport squadrons and no squadrons equipped for combat.
} 
ensure that the best possible candidates were retained. This process required applications be submitted through the chain of command to Commanding Officers for recommendations and then transmitted onward to the various Commands, each of which were given quotas by Air Force Headquarters (AFHQ), for consideration. Applicants up to the rank of Flight Lieutenant were approved by the Commands and those for individuals at higher rank levels were sent to AFHQ for final adjudication. ${ }^{38}$ Applicants were to be assessed on a 100-point scale, with up to 50 points given for service experience, with extra points allocated for those who joined early in the war, had command experience, and had achieved senior rank. Up to another 30 points were given for education and 20 points were allotted for "General Suitability", for which there were no formal criteria. Age was also a factor, with a formula being provided that forced older officers out of the service if they had not achieved sufficient rank in a reasonable time. ${ }^{39}$ Over time, this selection process proved to be difficult to implement evenly without more detailed instruction. For instance, there was apparently no requirement to provide documentary proof of educational achievement and investigation in one instance showed that an applicant's claim to "several" years of high school turned out to be two failed attempts at grade nine. ${ }^{40}$

\footnotetext{
${ }^{37}$ LAC, RG 24, Vol 3313, file HQ 282-5-10, contains numerous such requests. Memorandum 13-1-42, dated 26 January 1942 in this file provides an indication of the RCAF's decision not to resolve the issue of postwar Regular RCAF membership at that time.

${ }^{38}$ LAC, RG 24, Vol 3316, file HQ 282-8-5, Vol 1, letter S.45-4-65 (D of P), 14 September 1945.

${ }^{39}$ LAC, RG 24, Vol 3316, file HQ 282-8-5, Vol 1, letter 282-8-5 (DPC), 5 October 1945. The formula provided indicated that, from the Flying List, an officer's age could not exceed 30 plus years of service for Wing Commanders, 27 plus years of service for Squadron Leaders, and 25 plus years of service for Flight Lieutenants, Flight Officers and Pilot Officers. For the Non-Flying List, the formula indicated that an officer's age could not exceed 37 plus years of service for Wing Commanders, 33 plus years of service for Squadron Leaders, 30 plus years of service for Flight Lieutenants and Flight Officers, and 25 plus years of service for Pilot Officers.

${ }^{40}$ LAC, RG 24, Vol 3317, file HQ 282-8-5, Vol 2, memorandum 282-8-5 (D of T/T.3-4), dated 1 February 1946.
} 
One of the issues to be resolved related to the terms and conditions for service in the postwar RCAF, which had not yet been developed. This meant that personnel were being asked to join an organization that had not defined how long they would be wanted, what their pay and benefits would be or even if a pension would be available upon retirement after a full career. As a means of going forward, the intention in late 1945 was that those accepted into the Interim Force until 30 September 1947 would be informed of service condition details by 31 March 1946, at which time they could elect to remain with or leave the air force at the end of the Interim Period. ${ }^{41}$ As part of these terms of service, it was noted that serving personnel might have to revert to a lower rank in the Regular RCAF, including returning to the ranks after having been commissioned officers. ${ }^{42}$ Quite correctly, some expressed concern that this lack of definitive direction and confusion about opportunities for a fulltime career would result in personnel leaving early to secure good civilian jobs before they disappeared. ${ }^{43}$

Almost 240,000 Canadians served with the RCAF during the war. ${ }^{44}$ By the time manning levels for Scheme B were approved in February 1946, air force strength had shrunk to 50,036 , of which over 9,000 had already begun release procedures. These levels were to continue to drop fast. While the intention was to release an average of 3,000 personnel a month until the approved level of 16,100 was achieved, as of February 1946 only a small number of suitable candidates had volunteered and been accepted to

${ }^{41}$ LAC, RG 24, Vol 3313, file HQ 282-5-10, letter 282-5-10 (K4-2-2/32) dated 24 October 1945.

${ }^{42}$ LAC, RG 24, Vol 3316, file HQ 282-8-5, Vol 1, memorandum 282-8-5 (DPC), dated 23 January 1946.

${ }^{43}$ LAC, RG 24, Vol 3316, file HQ 282-8-5, Vol 1, memorandum entitled "Formation of Interim and Regular Air Force - Recruitment", from Air Vice Marshal K.M. Guthrie, AOC, to Chief of the Air Staff, dated 12 October 1945.

${ }^{44}$ C.P. Stacey, Arms, Men and Governments: The War Policies of Canada, 1939-1945 (Ottawa: Queen's Printer, 1970), Appendix R, p. 590, indicates that 222,501 men served in the air force and Mary Ziegler, The Story of the Women's Division Royal Canadian Air Force (Hamilton: RCAF (W.D.) Association, 1973), p. 159 indicates that 17,038 women served with the RCAF. 
continue in the air force. In view of this, the RCAF sought permission to reduce extraneous duties, so that available personnel could be concentrated on priority tasks. ${ }^{45}$ Cabinet soon agreed, directing that the occupation squadrons in Europe be withdrawn, RCAF mail service to Great Britain be discontinued, and the responsibility for maintenance of civilian aerodromes be returned to the Department of Transport. ${ }^{46}$ This helped, but the air force still had difficulties in filling the positions that remained due to the rapid pace of personnel departing.

The air force did little to help itself out of this difficulty. The staffing of the Interim RCAF proved to be a slow process. Although the air force had begun the selection procedure during the previous October, by 21 February 1946, only 443 applications had been received (332 men and 111 officers), of which 232 had been accepted (198 men and 34 officers) for continued service. Almost one-quarter of applicants were considered unsuitable, with 102 candidates rejected outright. The remaining 109 applications were caught in the bureaucratic process and were still being considered. ${ }^{47}$ To make matters worse, while there was limited difficulty in retaining personnel in the less skilled trades, there was a shortage in a number of critical, skilled areas. This best and brightest people were leaving in large numbers and not choosing to continue an air force career, which had been one of the basic assumptions by the RCAF. Within the officer corps, entry-level officers were offered an initial five-year Short Service Commission, followed by a ten-year Medium Service Commission and

\footnotetext{
${ }^{45}$ DND, DHH 181.009 (D4987), file number S.45-25-2 (AMAS), memorandum entitled "Reduction of R.C.A.F. to Authorized Post War Strength", from Minister of National Defence for Air to Cabinet, dated 12 February 1946.

${ }^{46}$ DND, DHH 112.1, Agenda of Meeting of Cabinet Defence Committee, September 1943 - February 1946, letter from A.D.P. Heeney, Secretary to the Cabinet, to Air Marshal Robert Leckie, Chairman, Chiefs of Staff Committee, dated 15 February 1946.
} 
then, for some, an indefinite Permanent Commission. Pension benefits were reserved for those with Permanent Commissions. Since more than half of the officers required for the permanent RCAF were to be offered only Short Service Commissions, many were surprised at the vagueness and uncertainty of the position in which they would be placed. ${ }^{48}$ This state of affairs did not encourage people to stay on and serve in the peacetime force, as attested by the low number of applicants.

Certainly the Rates of Pay did nothing to attract top recruits in 1946 - for other ranks, pay for an untrained Aircraftman ranged from $\$ 50$ monthly if living in quarters or $\$ 95$ if living off base and from $\$ 128$ to $\$ 188$, depending on living arrangements, for the most senior technicians, Warrant Officers Class I. Flying Officers earned from \$160-220 monthly. ${ }^{49}$ As a basis of comparison, around this time a bus driver in the Halifax area was making $\$ 168$ monthly and an untrained labourer in Vancouver made $\$ 147 .^{50}$ With these terms of service and pay, some personnel began changing their minds and withdrawing their applications for the Regular Force. ${ }^{51}$

There were even a range of government incentives that made departure from the military attractive. Veterans were given medical care, and disability allowances and support. Financial assistance was available for land purchase and there were housing subsidies. Upon returning to the civilian job market, service members were guaranteed

\footnotetext{
${ }^{47}$ LAC, RG 24, Vol 3317, file HQ 282-8-5, Vol 2, memorandum 282-8-5 (DPC/K5), dated 21 February 1946.

${ }^{48}$ LAC, RG 24, Vol 5225, file S-19-7-7, Vol 8, letter C27-1 (AOC), entitled "Terms of Service (Regular Air Force) - Officers", dated 27 March 1946, and RG 24, Vol 3211, file 186-1-11, Vol 1, letter 282-8-5 (D/ARMD), dated 16 May 1946.

${ }^{49}$ DND, DHH 193.009 (D53), Box 3, Pamphlet "Careers in the Armed Forces - A Message from the Chiefs of Staff, Navy, Army, Air Force and the Director General Defence Research", (Ottawa: King's Printer and Controller of Stationery, 1946), p.10.

${ }^{50}$ Government of Canada, The Canada Year Book 1947, (Ottawa: King's Printer and Controller of Stationary, 1947), p. 652. The Year Book identified salary on an hourly basis for these occupations and the
} 
their pre-war jobs, complete with seniority. Special allowances were given to those without employment. Veterans were also provided preference for public service jobs. For those interested in academic upgrading, tuition was free and a housing allowance provided. ${ }^{52}$ Little wonder the air force had difficulty retaining personnel in uniform. As time passed and the need for personnel remained, recruiting officers were directed in June 1946 to begin checking with the National Employment Service to obtain the name and addresses of unemployed former service personnel who could be approached about re-engaging in the air force. ${ }^{53}$ Efforts were made to improve conditions for those still in uniform. Married airmen would be allowed to obtain base housing for their families immediately following initial training for those above age 23 and an allowance would be provided to help move their families and household effects between postings. For single airmen, a single barracks room was promised to those holding the rank of sergeant or above, with those under that rank allotted a double room. Additional freedom was also allowed to RCAF members, who would no longer require special permission to leave the RCAF station during non-duty hours. Furthermore, the air force tried to improve the meals being served on the stations. ${ }^{54}$ Although wellintentioned, these measures were on the periphery and did not address the core problems of pay and job security.

monthly salary was determined by multiplying the hourly salary by 48 (the common work week at that time) and again by 52 (for the weeks in a year) and then divided by 12 (to determine monthly salary). ${ }^{51}$ LAC, RG 24, Vol 3313, file HQ 282-5-10, memorandum 282-5-10 (CAS), dated 28 September 1946. ${ }^{52}$ Reg Whitaker and Gary Marcuse, Cold War Canada: The Making of a National Insecurity State, 19451957, (Toronto: University of Toronto Press, 1994), p. 16.

${ }^{53}$ LAC, RG 24, Vol 3303, file 280-1-2, Vol 4, letter 280-1-2, from Wing Commander H.C. Ledoux, Office of the Chief of the Air Staff, to Command Recruiting Officer, Winnipeg, dated 10 June 1946.

${ }^{54}$ LAC, RG 24, Vol 5193, file 15-9-137, memorandum 300-9-3 (D of P), Press Release - Post-War Air Force, from Air Marshal Robert Leckie, Chief of Staff, to Minister of National Defence, dated 3 September 1946. 
These changes were not enough to reverse the surge of airmen leaving the service. By the end of 1946, it was estimated that personnel levels would be so low that some Regular Force squadrons would be down to 30 percent of the approved manning level. ${ }^{55}$ At that time, the RCAF was down to 12,735 service members and after the September 1947 termination of the Interim RCAF the strength would fall to $11,569,{ }^{56}$ well below its authorized strength. This difficulty extended to the Auxiliary, whose units encountered significant problems in attracting sufficient candidates.

The RCAF was failing at one of its fundamental requirements - the attraction and retention of quality personnel. Regardless of what plans were developed, the RCAF needed qualified officers and airmen to perform operations. Yet the RCAF failed in almost every regard in creating an attractive environment in which to serve. The air force was slow in determining which personnel were desirable for retention, causing those with abilities and potential to seek alternative careers rather than wait. Pay, which was determined by the government, was poor and uncompetitive. The terms of service were dreadful, requiring new officers to serve up to fifteen years before becoming eligible for a permanent commission and pension benefits. This state of affairs is strongly indicative of the overall lack of RCAF preparedness for the transition to a peacetime force. It is not surprising that the implementation of Scheme B, which will be described next, was chaotic.

Implementation of Scheme $B$

${ }_{55}^{55}$ AC, RG 24, Vol 5225, file S-19-7-71, Vol 9, Letter S19-7-71 (DASP), dated 1 November 1946.

${ }^{56}$ DND, DHH, 180.013 (D5), History of the Royal Canadian Air Force, undated, p. 26. 
After its approval by government in February, Scheme B was more fully developed under the title "Post War Plan for the Royal Canadian Air Force" and released in a final form in April 1946, after which it became popularly known as "Plan B". 57 Optimistically, the RCAF still foresaw an initial establishment of 676 aircraft between the Regular and Auxiliary Air Force and the purchase of another 1,000 aircraft over the following five years as replacements for worn out and damaged aircraft. The source of funding for these new aircraft, or even what they would cost, was not dealt with in the plan. Despite these difficulties, the full Plan B did contain some good news. An important difference in this version from that approved as Scheme B was the deletion of the Spitfire aircraft from the Fighter Reconnaissance role and the insertion of British-built De Havilland Vampires. ${ }^{58}$ These aircraft were to be the first acquisition of turbojet technology by the RCAF.

The RCAF acquisition of the Vampires is in itself indicative of the financial straits the air force found itself in during the initial postwar period. At the end of the war, the aircraft in the overseas squadrons and within Canada were ill suited for postwar service, due to their age, high usage and technological state. Because of more pressing domestic demands upon the public purse, the Canadian government was not able to fund new aircraft purchases. At the same time, the United Kingdom had a postwar financial obligation to Canada, in return for this country's provision of troops, training and equipment during the war. For instance, the Canadian government had negotiated an agreement that RCAF members posted to Royal Air Force squadrons during the war

\footnotetext{
${ }^{57}$ DND, DHH 181.004 (D44), Post War Plan for the Royal Canadian Air Force, April 1946. The practice of referring to postwar plans alphabetically (i.e. Plan E, Plan F, etc) continued into the 1950s.

${ }^{58}$ Ibid., Appendix G, Sheet 1.
} 
would be paid and maintained by the British. ${ }^{59}$ Since the United Kingdom was struggling with its own postwar financial difficulties, the prospects of direct financial compensation for this wartime debt were not good in the near term. In lieu of bringing back the aging aircraft from overseas, which would have been of limited utility, arrangements were made for the United Kingdom to provide the RCAF compensation in the form of more modern Vampire aircraft, which were just going into production. ${ }^{60}$

Negotiating under the authority of Order in Council PC624, dated 21 February 1946, the Canadian government agreed that the RCAF would obtain 183 Vampires from the British, in partial offset for wartime debt. This was seen as adequate to equip one Regular and seven Auxiliary RCAF squadrons with sufficient aircraft for operational service, wastage and maintenance reserve for a three-year period. ${ }^{61}$ The air force welcomed this opportunity to get to the next technological level and quickly amended Plan B to include this upgrade in capability.

However, in this rush to acquire jet propulsion aircraft, the RCAF failed to conduct an assessment of the Vampires' suitability for employment in the fighterinterceptor role within the Canada. The Canadian version of the Vampire had a single engine with $3100 \mathrm{lbs}$ thrust from a De Havilland Goblin 2 engine, capable of an operational ceiling of 43,500 feet, a top speed of $531 \mathrm{mph}$ and a range of 1090 miles. It was equipped with four $20 \mathrm{~mm}$ cannons. ${ }^{62}$ Since the large Canadian air space required aircraft with longer range, higher speed and heavier weaponry to intercept and destroy

\footnotetext{
${ }^{59}$ Douglas, op. cit., p. 213.

${ }^{60}$ DND, DHH, Raymont Papers, 73/1223, File 1820, Minutes of the $67^{\text {th }}$ Meeting of the Air Members, held at 1500 hours, Monday, 14 February 1949, p. 3.

${ }^{61}$ DND, DHH, Raymont Papers, 73/1223, File 1820, Minutes of the $67^{\text {th }}$ Meeting of the Air Members, held at 1500 hours, Monday, 14 February 1949, p. 4.

${ }^{62}$ www.rcaf.com/aircraft/fighters/vampire/index.php and http://en.wikipedia/org/wiki/De_Havilland_ vampire/index.php refers.
} 
intruders, it was soon evident that the Vampire was inadequate and would have to be replaced. But the Vampire was also one of the most advanced aircraft the British had and represented an introduction to the next technological level. By obtaining it, the RCAF gained needed experience in jet operations and maintenance.

Under Plan B, the RCAF was to be organized along geographic instead of functional lines because of the large land areas and small number of squadrons involved. RCAF Headquarters, Maintenance Command and No. 9 Transport Group were to be located in Ottawa. Eastern Air Command Headquarters in Halifax was responsible for the Maritime Provinces and those portions of the Arctic Islands and Quebec east of $80^{\circ}$ West longitude. No. 1 Air Command Headquarters in Trenton, Ontario, covered the portions of Ontario south of $53^{\circ}$ North latitude and east of $88^{\circ}$ West longitude, as well as those portions of Quebec west of $80^{\circ}$ West Longitude and $53^{\circ}$ North latitude. No. 2 Air Command, based in Winnipeg, was responsible for east of the heights of the Rocky Mountains, across Alberta, Saskatchewan and Manitoba, extending to those portions of Ontario not within the area of No. 1 Air Command. It was bound on the north by the $53^{\circ}$ North latitude. Western Air Command's area, with its headquarters in Vancouver, covered the remaining portions of British Columbia west of the heights of the Rocky Mountains. Edmonton's Northwest Air Command Headquarters was responsible for the area north of $53^{\circ}$ North latitude, less those portions covered by Eastern Air Command. ${ }^{63}$ Figure 3 depicts this division of responsibility.

${ }^{63}$ DND, DHH, 181.004 (D 44), Plan B - Post War Plan for the Royal Canadian Air Force, April 1946, pp. $8-9$. 


\section{Figure 3: Plan B Command Structure}

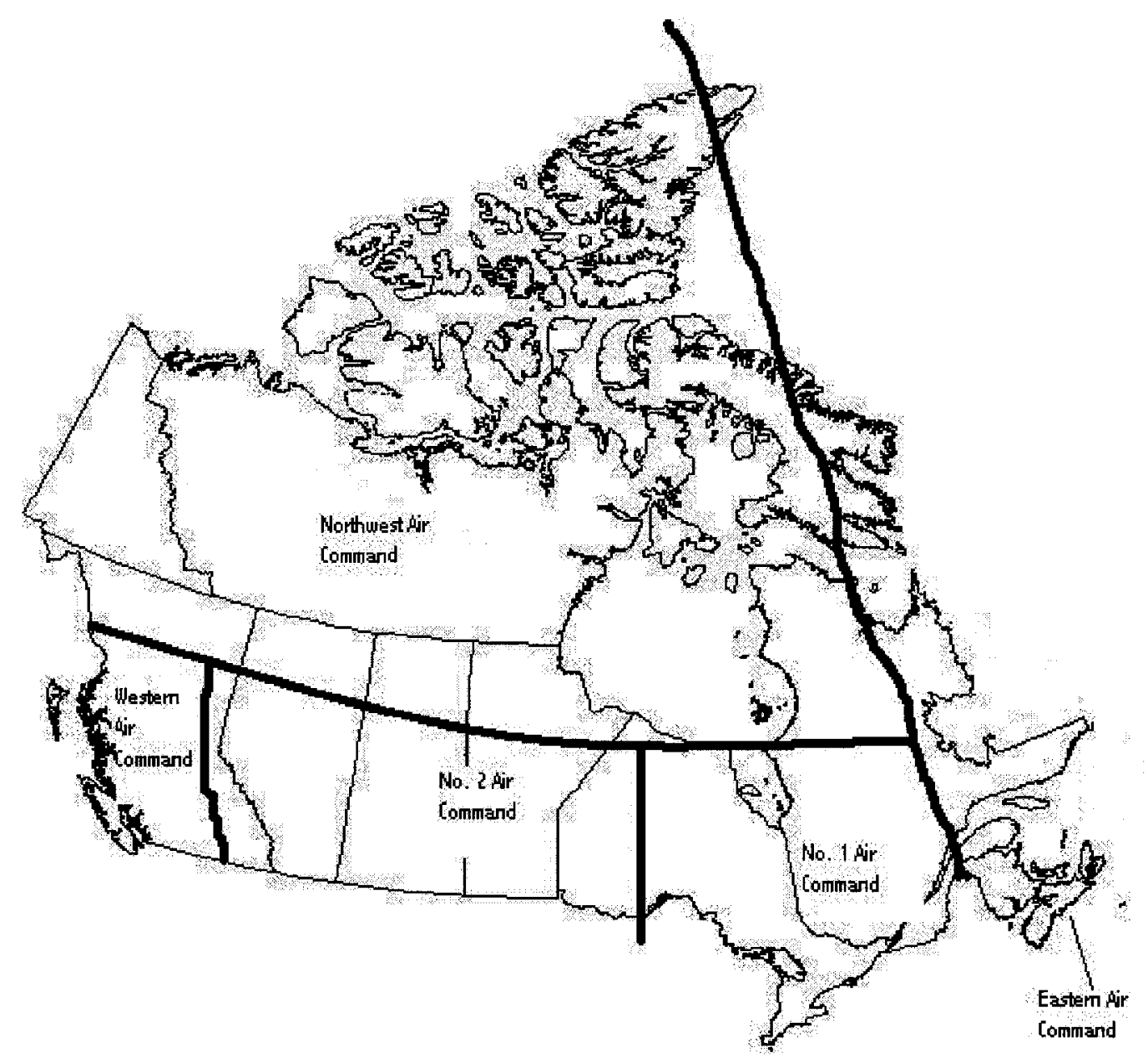

In order to accomplish its mission, in September 1946, the air force provided interim direction to the various Commands on the distribution of aircraft across the country, including:

Maintenance Command Headquarters, Uplands - six aircraft

Trenton: one twin-engine aircraft (unspecified) Calgary: one twin-engine aircraft (unspecified) Uplands: four Expeditors 
No. 1 Air Command Headquarters, Trenton - 32 aircraft

Trenton: 11 Expeditors and one Dakota

Mountain View: three Ansons and two Venturas

Aylmer: two Ansons

Borden: two Ansons

Montreal, Hamilton and Toronto Auxiliary Squadrons: four Harvards each

No. 2 Air Command Headquarters, Winnipeg - seven aircraft

Winnipeg: one Dakota and four Harvards for Auxiliary Squadron

Suffield: one Mitchell and one Anson

Eastern Air Command Headquarters, Halifax - six aircraft

Goose Bay: one Norseman

Dartmouth: one Dakota, two Cansos and two unspecified twin-engine Aircraft

Western Air Command Headquarters, Vancouver - seven aircraft

Sea Island: one Dakota, two Cansos and four Harvards for Auxiliary Squadron

Northwest Air Command Headquarters, Edmonton - ten aircraft

Edmonton: one Dakota, one Canso, four Expeditors and four Harvards for Auxiliary Squadron

No. 9 Transport Group Headquarters, Rockcliffe -56 aircraft

Rockcliffe: 16 Ansons, five Norseman, five Dakotas, four Mitchells, four Expeditors, two Gruman Groose, one Lodestar, one Canso, one Liberator

Edmonton: five Dakotas

Winnipeg: four Dakotas, one Beechcrafts, two Cansos, one Norseman Dartmouth: four Dakotas ${ }^{64}$

Despite Plan B's intention of fielding 676 frontline aircraft (which was down from the 727 initially wanted under the Post War Organization Committee), the RCAF 
was able to field only these 124 aircraft by late 1946 . The Vampires had not been received and were not as yet assigned to any Regular RCAF squadron. It is also notable that no Lancasters were retained to fulfil the bomber role mentioned in Plan B, or by Leckie in his letter to Tedder. Most of the allocated aircraft filled a training or transport role; none were suitable for the fighter-interceptor function. In the absence of bombers or fighters, the air force had virtually no aircraft appropriate for combat a little more than a year after the end of the Second World War.

The RCAF Auxiliary was no better off. Initial intentions were to have 15 squadrons performing frontline operations, operating at a range of locations across the country as indicated in Table 4. It was intended to provide each squadron 12 aircraft, with the fighter squadrons allocated eight Vampire jets and four Harvard aircraft for training. The light bomber squadrons were to have eight Mitchells and four Harvards and the fighter-bomber squadrons were to have eight Mosquitoes and four Harvards. ${ }^{65}$ Under Plan B, much of the air force's operational roles and combat capability was concentrated in the Auxiliary, including full responsibility for the fighter defence for Canada.

Following some delays, the air force eventually began preparations for the establishment of a number of Auxiliary Squadrons, releasing details in late December 1946 on the activation of five Regular RCAF and five Auxiliary Squadrons between 1 February 1947 and 1 October $1947 .^{66}$ But by mid-January 1947 these intentions had to be largely

\footnotetext{
${ }^{64}$ LAC, RG 24, Vol 5226, file S-19-7-71B, memorandum S19-7-71B, entitled "Interim Plan for RCAF, October 1/46 - March 31/47", from Wing Commander W.A.G. McLeish, DASP/J2-3 to AMAS, AMP, AMSO and D/Amrd.

${ }^{65}$ DND, DHH, 181.004 (D 44), Plan B - Post War Plan for the Royal Canadian Air Force, April 1946, p. 18.

${ }^{66}$ LAC, RG 24, Vol 5226, file S-19-7-71B, file S.19-7-71B (DASP), Air Force Directive J10, entitled

"Activation of R.C.A.F. Flying Units", 23 December 1946.
} 
deferred as the result of looming financial and personnel cutbacks. ${ }^{67}$ As will be described in later chapters, the road ahead for the Auxiliary was to prove to be difficult and it was never to achieve any significant operational role or capability.

Table 4: Plan B Auxiliary RCAF Proposal

\begin{tabular}{|l|c|l|c|}
\hline Location & Fighter Sqns & $\begin{array}{l}\text { Light Bomber } \\
\text { Sqns }\end{array}$ & $\begin{array}{l}\text { Fighter Bomber } \\
\text { Sqns }\end{array}$ \\
\hline Vancouver & 1 & & \\
\hline Victoria & 1 & & \\
\hline Edmonton & & & 1 \\
\hline Calgary & 1 & & \\
\hline Regina & 1 & & 1 \\
\hline Winnipeg & & & 1 \\
\hline London & & & \\
\hline Hamilton & & 1 & 1 \\
\hline Toronto & 1 & & 1 \\
\hline Ottawa & & 1 & \\
\hline Montreal & 1 & & \\
\hline Quebec & & & \\
\hline Halifax & 1 & & \\
\hline Total & 7 & 2 & \\
\hline
\end{tabular}

The implementation of Plan B showed a significant gap between what the RCAF intended to do and what was actually accomplished. The postwar air force failed to retain any fighting capability and was able to allocate fewer aircraft to squadrons than had been intended. Although there may have been some good will amongst veterans at the end of the war towards continued service, the RCAF failed to establish attractive terms of service, pay or conditions. This caused the air force to quickly losing people and an adequate number of replacements could not be found. The command structure was huge in comparison to what it controlled (Air Force Headquarters plus seven subordinate commands for under 12,000 personnel and few aircraft), which constituted a waste of

${ }^{67}$ LAC, RG 24, Vol 5226, file S-19-7-71B, message A702, file number S19-7-71B (DASP), dated 15 
resources in non-operational roles. The Auxiliary was given primary responsibility for the air defence of Canada, but there were delays in the establishment of Auxiliary squadrons and few aircraft were assigned to them. Canada was virtually without any air defence capability. Because of these events, Plan B implementation must be viewed as having been done in name only.

Role of Planning

The RCAF previously had not articulated exactly what was expected to be accomplished by the planning function. There was a wide scope for such activities within the air force and it would be useful to identify the perceived role of the planning function in order to assess how successfully it was carried out. Plan B articulated the expectations for air force planning, which consisted of air support to the Royal Canadian Navy and Canadian Army; participation in the defence of the Western Hemisphere; air force contribution in the event of hostilities outside of the Western Hemisphere; and a peacetime air force capable of speedy expansion. ${ }^{68}$ Plan B set out the basic principles that would influence RCAF plans, which identified a very wide range of responsibilities, including:

a. to make effectiveness in war the object of all development and training;

b. to advance the art of air warfare and promote the development of aerial and associated ground equipment;

c. to organize the Air Force for operations in all parts of Canada and beyond the territorial limits of Canada as required;

January [1947].

${ }^{68}$ DND, DHH, 181.004 (D 44), Plan B - Post War Plan for the Royal Canadian Air Force, April 1946, p. 3. 
d. to organize the Regular and Auxiliary operational squadrons to obtain maximum flexibility, mobility and effectiveness in strategic and tactical operations;

e. to provide air support and cooperation for the Royal Canadian Navy and the Canadian Army both at home and abroad;

f. to cooperate fully with other government departments and agencies;

g. to encourage the growth of commercial and private aviation;

h. to provide for the procurement and training of personnel required for an expanded war organization;

i. to acquire accurate information concerning the political, naval, military, air, economic and industrial policies of all nations;

j. to provide and maintain an Air Force communications system based on immediate mobilization and peacetime requirements;

k. to develop and maintain airbases and ground facilities required for the Regular and Auxiliary Air Forces;

1. to maintain such air bases and ground facilities on a care and maintenance basis as required for the operation of the Air Force in peace and war;

m. to plan the procurement of equipment to meet wartime and peacetime needs;

n. to keep the Air Force at the required strength balanced as to types by the additional construction or acquisition of aircraft;

o. to maintain plans for the rapid acquisition and necessary conversion of commercial aircraft for Air Force use in time of war;

p. to plan in cooperation with other government departments and agencies and with industry for the timely procurement of equipment and munitions necessary to maintain and augment a mobilized Air Force;

q. to plan for the maintenance of reserves of equipment and munitions to cover essential requirements beyond the productive capacity initially available in an emergency; and

r. to exercise economy in expenditures compatible with efficiency. ${ }^{69}$

${ }^{69}$ Ibid., pp. 3-4. 
This list provides evidence that postwar RCAF planning was intended to be an allencompassing role, supporting virtually every activity and aspect of the air force.

A problem for the RCAF was that although these planning activities largely appear to be reasonable, there was limited policy upon which the RCAF could justify these roles and responsibilities. Significant effort could be dedicated to developing plans for the future air force, which could then be rejected by their political masters on the basis of not being consistent with national goals. It was imperative for the RCAF that the federal government put forward a national policy statement on national defence, which did not occur until the 1947 release of a White Paper on Defence.

\section{Communism and Canada}

Virtually unnoticed by the public, in September 1945, cryptographic clerk Igor Gouzenko defected from the Soviet embassy in Ottawa with documents showing that espionage was being carried out in Canada. He and his family were kept safe while the government examined the evidence, which quickly showed that a number of Canadian public servants were providing classified information to the USSR on non-nuclear weapons, politics and atomic research. ${ }^{70}$ There were also indications of spying activities in Great Britain and the United States, whose governments were notified of this.

The America government established the Manhattan project in 1939, which led to the successful development of the atomic bombs that were dropped on Hiroshima and Nagasaki. America sought to keep this technology away from other countries, even proposing after the war that an international system of inspections be established and any

\footnotetext{
${ }^{70}$ Whitker and Marcuse, op. cit., pp. 27 and 34.
} 
country found to be pursuing atomic weapons be subject to immediate military attack. ${ }^{71}$ This was seen as a gambit to deny this technology to the Soviet Union. But the USSR well understood that agreeing to such a regime would make it vulnerable to American pressures. Throughout much of the war, the Soviet Union tried to development atomic technology and espionage was one of the means used to acquire this knowledge. The Gouzenko affair revealed that the Manhattan project was successfully targeted by the Soviets. $^{72}$

The Gouzenko defection became public knowledge in early February 1946, following a story by a Washington-based reporter, likely after a leak from a United States government official opposed to any system of international controls requiring compliance from the Soviet Union. President Truman reacted by reneging on an agreement to atomic cooperation with Canada and Great Britain, and blocking attempts to establish any international system of control. ${ }^{73}$ Within Canada, revelation of the spy scandal quickly led to the arrests of suspected spies under the War Measures Act and creation of the Kellock-Tashereau Royal Commission. ${ }^{74}$ In addition to the prosecution of the alleged spies, this commission resulted in enhanced security measures within the government, including the security screening of personnel, anti-communist legislation and persecution of suspected communists in the National Film Board. ${ }^{75}$ Public sentiment was anticommunist, as postwar Canada embraced capitalism and conservatism. ${ }^{76}$

\footnotetext{
${ }^{71}$ Campbell Craig and Sergey Radchenko, The Atomic Bomb and the Origins of the Cold War, (New Haven: Yale University Press, 2008), pp. 120-124 describe how, under the Acheson-Lilienthal report and Baruch Plan, atomic technology would be entrusted to the United Nations, which would establish inspection and verification systems to verify that no individual nation would obtain atomic weapons. ${ }^{72}$ Ibid., p. 115.

${ }^{73}$ Ibid., pp. 121-122.

${ }_{74}^{74}$ Whitaker and Marcuse, op. cit., pp. 56-57.

${ }_{76}^{76}$ Ibid., see Chapters 7-11 inclusive.

${ }^{76}$ Ibid., p. 13.
} 
Canada already had a legacy of anti-communist behaviour. Japanese-Canadians had been interred during the war as a precautionary security measures, but so were some Ukrainian-Canadians, communists and fascists. ${ }^{77}$ Before and during the war, Mackenzie King and his government viewed communists as a threat, leading to charges of sedition and subversion of strike leaders and censorship through publication bans for communist publications. Canadian anti-communism did not date from the Gouzenko defection, but pre-dates it. Whitaker and Marcuse wrote that the "continuity of anti-Communism throughout the twentieth century is more striking than any sudden oscillations of illusion disillusion. Suspicion of the USSR and Communism had always been characteristic of the Canadian government and administrative elites. The wartime alliance changed nothing in this regard." 78

The origins of the Cold War has been attributed to a number of factors, including American possession of and Soviet desire for atomic weapons, the Gouzenko affair and Winston Churchill's "Iron Wall" speech at Westminster College in Fulton, Missouri, on 5 March $1946 .{ }^{79}$ However it started, the Cold War provided the impetus behind much of the postwar growth of the RCAF, as the Soviet threat to North America and European democracies became more evident.

\section{Hope for the Future}

Despite the setbacks experienced by the RCAF during the later parts of 1945 and throughout 1946, there were some initial steps towards the development of a modern force. During a meeting between air force and Canadian and British aviation industry

\footnotetext{
${ }^{77}$ Ibid., p. 8.

${ }^{78}$ Ibid., p. 11.
} 
representatives in September 1945, the RCAF outlined the specifications for a singleperson, single engine jet fighter with 5,000 pounds of thrust. W.W.W. Downing of A.V. Roe Canada was "horrified" at this, noting that more powerful engines were already on line and that a two-engine aircraft would be more suited for Canadian geography. ${ }^{80}$ While nothing of substance came from this meeting, the RCAF was to take the feedback from industry and, under the leadership of Air Vice Marshal Wilf Curtis, eventually revised the specifications for the next generation of fighter. ${ }^{81}$ For Curtis, there was no question that it had to be Canadian-built. During the war, he unsuccessfully approached the British to acquire some fighters for home defences; at that time, he "realized ... that until we didn't have to tip our hats to anyone to get aircraft when we needed them, we'd never have the air force a first rate nation really deserves. ${ }^{, 82}$ The re-written specifications indicated that:

The aeroplane shall be powered by two gas turbine jet propulsion engines and shall provide for a crew of two. It shall be of all metal construction with a pressurized cabin.... The range ... shall be sufficient to permit ... Taxi and run-up 4 minutes, takeoff 1 minute at takeoff RPM, climb to 40,000 feet, cruise to a radius of action of 650 nautical miles, combat 15 minutes at 490 knots at 40,000 feet, return cruise 650 nautical miles, descent 10 minutes from 40,000 feet, approach 7 minutes idling RPM. The operational ceiling shall not be less than 50,000 feet.... The maximum true air speed in level flight at 40,000 feet altitude shall not be less than 490 knots $(.85$ Mach $) .{ }^{83}$

To arrive at these specifications, Curtis indicated that "[f]irst we had to look at the specifications for the best bombers in the world, how high they could fly, and how fast.

\footnotetext{
${ }^{79}$ For a summary on the origins of the Cold War, see Craig and Radchenko, op. cit, pp. 162-170.

${ }^{80}$ Craig Stewart, Shutting Down the National Dream - A.V. Roe and the Tragedy of the Avro Arrow (Toronto: McGraw-Hill Ryerson Limited, 1988), pp. 59-60.

${ }^{81}$ Ibid., p. 61.

${ }^{82}$ Ibid., p. 62.
} 
Then we asked for a fighter which would fly higher, and fly faster. ... That is precisely how the CF-100 [Avro Canuck] was born. ${ }^{, 84}$ The Canuck would have two engines compared to the Vampire's one, which meant that the new aircraft could continue flying should one engine cease to work. The Canuck could also fly higher, faster and further than the Vampire. Another attribute of the CF-100 was that it provided a solid base from which to fire at intruding aircraft. ${ }^{85}$ Overall, the Canuck was a much better aircraft for the RCAF and represented progression in the acquisition of jet propulsion technology. The requirement for an all-weather fighter had been satisfied; what remained was finding a new day interceptor to replace the Vampire. In October 1946, the RCAF signed a contract with A.V. Roe Limited for three prototypes based upon these specifications ${ }^{86}$ for initial test flying, static testing and flight testing with modifications. ${ }^{87}$ The first CF-100s were completed in late 1949 and testing began in January $19500^{88}$

\section{Conclusion}

The immediate postwar period was difficult for the RCAF, as it rapidly demobilized from a large, combat-capable, multi-purpose air force to a shadow of its former self, able only to perform limited transport missions and some flight training. On the surface of it, the RCAF decision to give up the heavy bomber role appears to have been contrary to its wartime experience in No. 6 Bombing Group, which represented Canada's largest air combat role during the Second World War. While the high

\footnotetext{
${ }^{83}$ Larry Milberry, The Avro CF-100 (Toronto: CANAV Books, 1981), p. 13.

${ }^{84}$ Stewart, op. cit., p. 64.

${ }^{85}$ For complete details on the CF-100, see Milbury, op. cit.

${ }^{86}$ Randal Wakelam, "Flights of Fancy: RCAF Fighter Procurement 1945-1954", unpublished MA thesis in War Studies, Royal Military College of Canada, Kingston, 1997, p. 66.

${ }^{87}$ Milberry, op. cit., p. 14.

${ }^{88}$ Ibid., p. 15.
} 
manpower demand for bomber squadrons in peacetime was a factor in this, it should also be remembered that this role was an aberration - the pre-war air force had no comparable capability. Moreover, the offensive nature of heavy bombers was basically in conflict with the defensive nature of the postwar air force plans. Plan B foresaw Regular and Auxiliary RCAF squadrons keeping a medium bomber capability, but this was part of the vision for an all-round force and was the means of providing tactical support to the Canadian Army. Still, the decision to give up heavy bombers did not sit well with some senior officers of the air force and the possibility of fielding such aircraft was to be revisited a number of times in the future.

During this transition from a wartime air force to a peacetime force, defencerelated planning in general, and RCAF-related planning specifically, was at a rudimentary level. It resulted in poor plans, coordination and resource management. Planning activities that did take place were often unrealistic and perhaps even grandiose at times, requiring government intervention to provide corrective guidance to keep plans aligned with overall government intentions and fiscal capacity. In fact, the process at this time lacked a means for ongoing political feedback on and oversight of air force plans before reaching the Minister of National Defence for Air. ${ }^{89}$ There was thus often a gap between what the RCAF wanted in their plans and what the government was willing to support. The lack of a cohesive and collaborative planning process was evident within the RCAF itself, as Air Marshal Robert Leckie at times appeared in conflict with or, at least, uninformed of initiatives within his own service. The plans developed by the

\footnotetext{
${ }^{89}$ Plan B and its initial implementation took place under the stewardship of Colin Gibson, as Minister of National Defence for Air, with the amalgamation of the army, navy and air force under a single Minister of National Defence, Brooke Claxton, not occurring until December 1946.
} 
RCAF during 1945 and 1946 were of poor quality and exerted little influence over government decisions.

The RCAF's role under Plan B was to provide "a well balanced nucleus of highly proficient personnel, which is capable of rapid, efficient expansion in the event of an emergency". ${ }^{90}$ The gap between the 676 aircraft required under the plan and the 124 actually fielded adversely affected the air force's ability to train personnel. Aircrew could not be "highly proficient" in the military arts without the equipment to practice their combat skills. The creation of seven subordinate commands to oversee the operations of this limited number aircraft was excessive. A better solution would have been to concentrate resources on operational roles. Five of these commands had ten aircraft or less. None of the commands was responsible for training, making "rapid, efficient expansion" difficult to achieve without further reorganization. And the inability of the air force to retain personnel resulted in some units operating with 30 percent of their authorized strength. ${ }^{91}$ Therefore, the force size and structure implemented under Plan B was ineffective and unrealistic for the resources available. Plan B was a relatively amateurish effort, with little substantive detail and providing an incomplete basis for building the air force of the future.

In fairness, the shifting political and defence environment made defence planning difficult. The air force failed to achieve its political or strategic goals and was forced to downsize significantly, largely due to the RCAF's inability to convince the political leadership of the requirement for a more substantial and capable air force. A symptom of this state of affairs was the absence of substantial discussions between the two that would

\footnotetext{
${ }^{90}$ DND, DHH 181.004 (D44), Post War Plan for the Royal Canadian Air Force, April 1946, p. 1.

${ }^{91}$ LAC, RG 24, Vol 5225, file S-19-7-71, Vol 9, Letter S19-7-71 (DASP), dated 1 November 1946.
} 
have led to a common understanding of political or strategic goals. The government understandably placed a much higher priority on demobilization and establishing a peacetime economy than on maintaining a large military force at a time of little known threat. The quality of Plan B was also influenced by the short, seven-week period in which it was produced, as final government direction on personnel levels and funding was received on 19 December 1945, with the plan being approved on 4 February 1946. If its situation was going to change for the better, the RCAF had to be able to better justify its request for resources and to improve the manner in which it went about presenting its case to government.

The complete lack of any combat capability that resulted from Plan B implementation is compelling evidence of a lack of effectiveness by RCAF planners. There was hope for improvements in the future because of the initial steps taken to introduce new technology through the Vampires and the specifications for the CF-100 Canuck. Yet these small successes did not offset all the cutbacks.

The RCAF did provide some early indications of behaviour associated with a professional military. The air force actively promoted its interests and sought to convince the government not to impose such severe reductions. The re-examination of the bomber role is an example of the RCAF promoting its own interests, as senior leadership sought to retain a familiar role for which little political interest was expressed. Responsibilities not wanted by leadership were set aside, including mail service to Great Britain and air force involvement in running civilian airports. RCAF involvement with the Northwest Staging Route and aerial photography only followed explicit government direction. From 
this, it is possible to discern the beginnings of RCAF behaviour favouring organizational self-interest.

There was an opportunity on the horizon for the air force to change its fortunes. The onset of the Cold War was leading to a bi-polar security environment. With Canada situated directly between the two major antagonists, the air threat was likely to increase as time passed and the RCAF was situated to provide the primary Canadian response to it. But to take advantage of this circumstance, the air force had to be professionally competent, and be able to develop and articulate plans acceptable to the government. How the RCAF dealt with these three factors (the Cold War, professionalism and planning) would define the future for the air force.

In summary, the immediate postwar period for the RCAF was typified by rapid demobilization and government-led restructuring of the economy. The socio-political environment rendered many of the preparatory planning activities by the air force redundant, as none of the RCAF Post War Organization Committee's recommendations survived the war and Plan B was only partially implemented. There was little sustained consultation between the political masters and the air force, as the government decided to focus on wider issues of governance. Both the government and the air force bore responsibility for this. The social and economic initiatives by the government were appropriate, but national defence also required political oversight and direction. The RCAF needed to become more professional and effective at planning if the government was to be convinced to give support, and the Cold War provided the impetus for this to occur. 
Not surprisingly, air force members remember from the end of the Second World War until the end of 1946 as a time of cutbacks and retrenchment. Air Commodore R. C. Ripley, while acting as Chief of the Air Staff, later recalled that "[t]his period saw us slump to a very bitter stage". 92

${ }^{92}$ LAC, RG 24, Vol 17666, file 045-7, Vol 1, memorandum 194-2-6 (CAS), dated 28 December 1948, from Air Commodore R.C. Ripley, Acting Chief of the Air Staff, to Air Historian, commenting on the RCAF Logbook project. 


\section{CHAPTER THREE}

\section{THE BASIC SECURITY PLAN:}

\section{PLANNING FOR NORTH AMERICAN AIR DEFENCE, 1946-1948}

Formal military cooperation between the United States and Canada pre-dated America's entry into the Second World War by more than a year, with the August 1940 signing of the Ogdensburg Agreement. Amongst other initiatives, this led to the wartime Canada-United States Defence Plan, ABC-22, which provided for mutual defence. In late 1945, Canadian political and military leadership knew that ABC-22 had to be revised to consider the postwar environment and the military was authorized to collaborate with their American counterparts to update this plan. ${ }^{1}$ Consequently, much of the staff effort between 1946 and 1948 went into development of the Basic Security Plan with the United States.

This period proved to be critical for the expansion of the RCAF, as the growing perception of the Soviet threat and the resultant need for enhanced air defence for North America was central to the Basic Security Plan. The planning activities associated with the development of this plan, which led to the development of a fighter-interceptor force, the establishment of a radar chain across Canada in order to provide early detection of an intruder and the construction of airbases from which the fighters could operate, are the focus of this chapter.

\footnotetext{
${ }^{1}$ Ibid., CSC 101-1, 21 December 1945, from A.D.P. Heeney, Secretary to Cabinet to Vice-Admiral J.C. Jones, Acting Chair, Chief of Staff Committee.
} 
Identifying the Threat

One of the first issues identified by Canadian and American military representatives involved in developing the successor to $\mathrm{ABC}-22$ related to how the threat to North America would be defined. This kind of assessment provided insights into Canadian and American defensive vulnerabilities and helped identify vital points, such as industrial centres and defensive sites, which could be open to attack. Analysis of these helped defined the defensive capabilities required in the Basic Security Plan. As early as January 1946, it was acknowledged that production of this Canadian-American plan required the:

full exchange of intelligence information as it affects the security of the North American continent, as well as for full exchange of professional and technical information.... The basis of the study must be the strategic appreciation estimates as to the origins of[,] forms and scales of attack based on the most accurate intelligence information available and a scientific appreciation of the probable progress in the development of new weapons, etc. ${ }^{2}$

This requirement was to be recognized as a necessity by both sides and would contribute to the exchange of intelligence and the development of mutually beneficial defence plans between the two countries for many years to come.

The RCAF embraced the requirement for such intelligence appreciations. Air Marshal Leckie noted during a meeting of the Chiefs of Staff Committee that these appreciations should be used "as the broad basis for the continuation for development of active military co-operation between the two countries." ${ }^{3}$ Wartime experience showed that cooperation was possible across a range of military endeavours, involving each of the

\footnotetext{
${ }^{2}$ LAC, RG 24, Vol 5176, file S-15-1-204, Vol 14, memorandum S.15-1-204 (DASP/J.2), from Group Captain W.W. Bean, DASP/J.2 to AMAS, dated 14 January 1946.

${ }^{3}$ DND, DHH, 193.009 (053), Box 1, 1946, Papers and Meetings, Chiefs of Staff Committee, Minutes of the $353^{\text {rd }}$ Meeting, 7 June 1946 , p. 2.
} 
three services. Intelligence officers briefing the Chiefs of Staff concurred with this point of view, indicating that the threat to Canada "in their opinion called for a new concept of continental defence., ${ }^{, 4}$ Because of technological advances over the war years, Canada had to consider the possibility of attack from the north for the first time. Advances on the range of aircraft, guided missiles and rockets, and atomic weapons contributed to the perception that Canada was more vulnerable than ever before. Cooperation with the Americans on the Basic Security Plan would help identify the new concept of defence that would address these concerns.

December 1946 saw the production of the first of many postwar threat appreciations, which included a significant focus on the potential for Soviet aggression on North America from the air. It indicated that "Soviet Communist ideology maintains that continued struggle between capitalism and communism, including war if necessary, is inevitable." As the Soviet economy recovered from the war, it was expected that strategic air forces and submarine fleets would be developed, followed by the production of atomic weapons. Soviet forces were likely to eventually seek to overrun continental Western Europe, followed by a bombardment campaign to reduce British defence production capability. Concurrent with this, "it is probable that harassing attacks by long-range bomber forces would be made against the industrial complex of the eastern US and Canada." Under such circumstances, it was anticipated that it would take western powers a long time to organize and respond, meaning that initially "the only offensive means available ... would be very long-range strategic bombing. Owing to the long flights required over Soviet-dominated territory such attacks might produce an

\footnotetext{
${ }^{4}$ Ibid.
} 
attrition rate impossible of acceptance over long periods." ${ }^{, 5}$ The initial solution for North American security did not lay in the development of offensive forces, but in the creation of defensive capabilities.

In response to this threat, the intelligence appreciation called for air defences capable of providing early warning of an approaching threat, a network of air bases away from vital strategic industrial areas that would be equipped with interceptors, adequate anti-aircraft defences and the capability to deploy troops by air to dislocate any enemy lodgement in the north. ${ }^{6}$ The appreciation went on to argue that the complexity, and training and equipment requirements associated with the interceptor forces were such that forces intended to protect against the evolving Soviet air threat had to be "in being".? "Forces in being" are military personnel that are trained and ready for combat by the government in the event of conflict, not mobilized afterwards. This meant that Plan B, which was finalized in February 1946, was demonstrably inadequate just ten months after being written. This plan was designed to prepare the RCAF to serve as the basis for rapid mobilization in the event of an emergency, ${ }^{8}$ not as a defence force against attack. The intelligence appreciation requirement for forces in being also provided the justification for the interceptor role to reside with the Regular RCAF, not with the part-time Auxiliary. This would be the first in a long line of Regular Force moves to increase its role at the expense of the Auxiliary RCAF. Paradoxically, while asserting that it was "not considered necessary to increase air interceptor forces during the forthcoming year", the joint assessment also stipulated that the absence of sufficient fighters was an "immediate

\footnotetext{
${ }^{5}$ LAC, RG 24, Vol 6174, file HQ 19-7-79, Vol 1, Joint Appreciation and Plan: Canadian Armed Services, Parts I, II, II and Appendices A, B1, B2, B3, December 1946, p. 3.

${ }^{6}$ Ibid., p. 12.

${ }^{7}$ Ibid., p. 14.
} 
deficiency".9 The appreciation concluded "the provision of defence against air attack is considered to be of great importance. It is obvious that our present air force cannot provide this defence without substantial increase in size". ${ }^{10}$ It also recommended that, following the development of the Basic Security Plan's Air Warning and Air Interceptor appendix, the RCAF be increased by "at least fifty percent". ${ }^{11}$

In time, the basic lines of reasoning presented in this threat assessment and many of the assessments that followed were critical to the long-term growth of the RCAF. These documents indicated that the Soviet threat was primarily against Europe but that North America would be subjected at least to diversionary attacks. As the range of Soviet aircraft increased and the development of a Soviet atomic bomb became more likely, the perception was that the threat to North America increased. Canada's response to this provided much of the impetus for the later introduction of jet aircraft and the establishment of fighter bases and radar sites across the country. In fact, in the absence of a Soviet air threat, there is little reason to believe the RCAF would have gone on to experience the level of growth that later occurred.

Since North America was never subjected to a Soviet air attack, it is relatively easy to dismiss the value and accuracy of these threat assessments. But there were sufficient indications that the Soviet Union posed a risk to democratic nations. A basic tenet of communist philosophy was that communist and capitalist nations could not coexist and that conflict between the two was inevitable. ${ }^{12}$ Stalin emphasized this during

\footnotetext{
${ }^{8}$ DND, DHH 181.004 (D44), Post War Plan for the Royal Canadian Air Force, April 1946, p. 1.

${ }^{9}$ LAC, RG 24, Vol 6174, file HQ 19-7-79, Vol 1, Joint Appreciation and Plan: Canadian Armed Services, Parts I, II, II and Appendices A, B1, B2, B3, December 1946, p. 18.

${ }^{10}$ Ibid.

${ }^{11}$ Ibid.

${ }^{12}$ Clark Clifford, "American Relations with the Soviet Union", 24 September 1946, Conway Files, Truman Papers, Harry S. Truman Library, p. 3.
} 
a radio broadcast to the Soviet people in February 1946, in which he blamed the Second World War on imperialism and asserted that communism would be in danger from this so long as there was capitalism..$^{13}$ The Soviet Union had long pursued a policy of expanding its sphere of influence, including its June 1940 occupation of Latvia, Estonia and Lithuania and concession of Poland to the Soviet sphere by the Yalta agreement in 1945. Coercion in eastern Europe in the immediate postwar period effectively led to Soviet political control of Hungary, Poland, Rumania and Bulgaria. ${ }^{14}$ After the Second World War, western democracies saw Communist parties emerge as government coalition partners in France, Belgium and Italy. Following the outbreak of a communist insurgency in Greece in March 1946, the Truman Doctrine was announced to ensure that Greece and Turkey did not fall into the Soviet sphere of influence. ${ }^{15}$ The Soviet Union also made a regular display of its military might, as shown by the large annual May Day parade before the political elite in Moscow. The Cold War had begun and western democracies had to decide how they would respond. The assessments were simply a codified means of articulating the threat in order to assist with the development of defensive plans and the identification suitable counter-measures.

Sometimes, nevertheless, the assessments did exaggerate the timing, nature or extent of the threat. If there was a fault in the process, it was that these documents appear to have been largely accepted without being challenged. A critical review of the assessments would have provided the opportunity for sober second thought before committing the country to significant expenses and responsibilities. For instance, a

\footnotetext{
${ }^{13}$ J.L. Black, "Kanada-Votchina Amerikanskogo Imperializma: Canada and Canadian Communists in the Soviet 'Coming War' Paradigm, 1946-1951”, pp. 160-161, in Donaghy, op. cit.

${ }^{14}$ Clifford, op. cit., p. 10.

${ }^{15}$ Black, op. cit., p. 162.
} 
common theme in many assessments related to the threat of a Soviet landing in northern Canada, from which attacks could be launched. But beyond speculation within the intelligence community, there was and is no substantive evidence that the Soviet Union was considering this kind of attack. Yet the RCAF later obtained transport aircraft and dedicated some Auxiliary units to support a Canadian Army deployment to the north to counter such a Soviet landing and there were annual military exercise practicing for such an eventuality for many years.

\section{Political Oversight of the Basic Security Plan}

On 19 December 1945, Douglas Abbott, Minister of National Defence, approached Cabinet for authority for the three services to enter into discussions with the United States military to update the joint Canada-United States defence plan, ABC-22. ${ }^{16}$ This initiative was approved, with the condition that civilian authorities from other departments participate. To facilitate the production of the Basic Security Plan, under the auspices of Permanent Joint Board on Defence Recommendation 35, ${ }^{17}$ a CanadianAmerican Military Cooperation Committee (MCC) was formed, which met regularly to produce and oversee plans related to a range of issues, including appendices on air interceptor and air warning system, anti-aircraft ground defence, strategic air reconnaissance, military intelligence, air photography, and mobile striking forces. ${ }^{18}$ The combination of these appendices would form the Basic Security Plan.

\footnotetext{
${ }^{16}$ LAC, RG 2, Vol 2748, Vol 1, Minutes of the Tenth Meeting of the Cabinet Defence Committee, held in Room 568, House of Commons, on Tuesday 4 December 1945, p. 2, paras 3-4.

${ }^{17}$ DND, DHH 193.009 (D53), Box 1, Papers and Meetings, Chiefs of Staff Committee, Minutes of the $366^{\text {th }}$ Meeting of the Chiefs of Staff Committee, dated 8 October 1946.

${ }^{18}$ DND, DHH 193.009 (D53), Box 2, Papers and Meetings, Chiefs of Staff Committee, Vol 68, August 1947, file number J.P.C. 3-0, entitled "Chiefs of Staff Committee - Joint Planning Committee Progress Report No. 4", dated 26 July 1947.
} 
A briefing on the initial results of this planning collaboration with the Americans was provided to the Cabinet Defence Committee on 9 July 1946. The Directors of Intelligence from the three services provided an overview of the military strength of potential enemies and possible forms of attack. The unsettled state of the world was discussed, as was the increased range of aircraft and the potential for destruction from weapons delivered from the air. The briefing concluded with recommendations for increased defensive measures in the Canadian north. ${ }^{19}$ Lieutenant General Charles Foulkes, Chief of the General Staff, described the efforts of the MCC and the various appendices under production, with special mention made of the priority given to the creation of an effective air warning system. The serious fiscal implications of adopting the Basic Security Plan were acknowledged and the Chiefs of Staff Committee expressed hope that an improvement in the world situation would allow plan implementation on a reduced scale. ${ }^{20}$ Copies of the draft plan were provided to each Minister ${ }^{21}$ and the Cabinet Defence Committee adjourned in order to study the documents. ${ }^{22}$

The Cabinet Defence Committee reconvened two weeks later without directly commenting on the contents of the plan. However, the Committee did endorse the joint planning process with the United States, so that the different components of the plan could be further developed. ${ }^{23}$ Given the wide-ranging political, financial and military implications of the Basic Security Plan, this approval was a positive sign of the work

\footnotetext{
${ }^{19}$ LAC, RG 2, Vol 2748, Vol 1, Minutes of the Twentieth Meeting of the Cabinet Defence Committee, held in the Privy Council Chamber, Tuesday, July $9^{\text {th }}, 1946$, para 4, p. 3.

${ }^{20}$ Ibid., paras 5-6, pp. 3-4.

${ }^{21}$ At this time, the Cabinet Defence Committee included the Prime Minister, Minister of Finance, Minister of Agriculture, Minister of National Defence, Minister of National Defence for Air, Minister of Justice, Minister of National Health and Welfare, and the Secretary of State for External Affairs.

${ }^{22}$ LAC, RG 2, Vol 2748, Vol 1, Minutes of the Twentieth Meeting of the Cabinet Defence Committee, held in the Privy Council Chamber, Tuesday, July $9^{\text {th }}, 1946$, para 9, p. 4.
} 
being done by the services. At the Cabinet Defence Committee meeting that followed, the Minister of National Defence undertook to provide periodic briefings to the Committee ${ }^{24}$ which showed that there was ongoing consultation between the Minister and the services. This was indicative of improved communication between the military and the political leadership, which had been a problem area for the RCAF when drawing up the first postwar plans.

Political oversight of the Basic Security Plan intensified during November 1946 through the indirect participation of the Prime Minister. At a meeting of the Cabinet Defence Committee, Mackenzie King indicated that he had recently discussed defence matters with American President Harry Truman. ${ }^{25}$ Issues related to sovereignty, cost sharing, standardization and the location of American troops on Canadian soil were mentioned without firm decisions being reached on any point. These matters were not components of the Basic Security Plan, but they did contribute to the general framework under which defence collaboration would take place. As such, they had to be resolved before any agreement on how to defend North America could be finalized. Before following these points up at the political level, the Prime Minister asked to be updated on the general strategic situation and on the latest progress with the Basic Security Plan. ${ }^{26}$

Air Vice Marshal Leckie reminded the Cabinet Defence Committee of the intelligence appreciation presented on 9 July, which included discussion on the threat that resulted from the range and power of modern weapons. The risk from the air had been a

\footnotetext{
${ }^{23}$ LAC, RG 2, Vol 2748, Vol 1, Minutes of the Twenty-first Meeting of the Cabinet Defence Committee, held in Room 568, House of Commons, Wednesday, July $24^{\text {th }}, 1946$, para 4, p. 2.

${ }^{24}$ LAC, RG 2, Vol 2748, Vol 1, Minutes of the Twenty-second Meeting of the Cabinet Defence Committee, held in the Privy Council Chamber, Wednesday, September $18^{\text {th }}, 1946$, para 24, p. 7.

${ }^{25}$ LAC, RG 2, Vol 2748, Vol 1, Minutes of the Twenty-fourth Meeting of the Cabinet Defence Committee, held in the Privy Council Chamber, on Wednesday, November 13 ${ }^{\text {th }}, 1946$, para 4, p. 2.

${ }^{26}$ Ibid.
} 
central focus in the earlier assessment. Leckie emphasized that North America could no longer be considered immune from attack and that this danger would only increase with the spread of atomic bombs. He noted that the Basic Security Plan had been further developed, with particular attention being paid to the air defence scheme. These developments had not been briefed to the Chiefs of Staff Committee, but Leckie's preliminary review of the updated documents had caused him concern. He was worried about the scope of the air defence measures envisaged by the plan and their associated costs. This caused him to question the strategic concept that underpinned the Basic Security Plan. ${ }^{27}$

The strategic concept held that an attacker in the future would target the industrial capability of North America before invading other countries. Industrial capacity was an area of clear advantage for the western democracies over the Soviet Union. Canadian and American industries had been spared attack during the Second World War, so North American industrial output was higher than many other countries. As had occurred during the war, this industrial capacity could be used to gain military advantage. ${ }^{28}$ Leckie, however, believed that any aggression against Canada or the United States would be of a diversionary nature. He questioned the requirement for "an elaborate defence scheme employing our resources in a static role" and underlined the very high costs involved in establishing an air defence network. Leckie suggested that more modest defensive arrangements were appropriate. ${ }^{29}$

\footnotetext{
${ }^{27}$ Ibid., para 5, p. 3.

${ }^{28}$ For the classic work on Canada's war output, see C.P. Stacey, Arms, Men and Government - The War Policies of Canada (Ottawa: Queen's Printers, 1970).

${ }^{29}$ LAC, RG 2, Vol 2748, Vol 1, Minutes of the Twenty-fourth Meeting of the Cabinet Defence Committee, held in the Privy Council Chamber, on Wednesday, November $13^{\text {th }}, 1946$, para 5, p. 3.
} 
The Chief of the General Staff acknowledged that extensive defensive works were not needed just to protect against sporadic attack but also indicated that he leaned towards the American strategic concept. He believed that North America could no longer be considered safe from attack and that military planning had to take this into account. He also indicated that British military opinion was in agreement about industrial capability being targeted at the outset of hostilities. ${ }^{30}$ This exchange between Foulkes and Leckie was peculiar, in that the head of the army advocated spending large sums on air defence and the leader of the air force argued against it. In this instance at least, Janowitz' assertion that military professionals acted out of self-interest was not borne out.

This information reinforced the Prime Minister's opinion that direct negotiations were needed between the Canadian and American governments in order to ensure that the joint planning activities being carried out were appropriate. The Undersecretary of State for External Affairs, Lester Pearson, had already convinced Mackenzie King that defence cooperation with the United States was necessary in the face of a Soviet system intent upon conflict with the west. Arguing that the next war would be "short, nasty and brutish" and that Canada was vulnerable because of new weapons, Pearson gained King's support for Permanent Joint Board on Defence Recommendation 35 and the extensive peacetime military collaboration between Canada and the United States that ensued. ${ }^{31}$

Mackenzie King noted that, in the ongoing discussions with the United States, "the principal emphasis appeared to be on air defence. This raised the question of the relative size of the RCAF in the current programme in comparison with those of the other

\footnotetext{
${ }^{30}$ Ibid., para 6, p. 3.

${ }^{31}$ John English, Shadow of Heaven: The Life of Lester Pearson, Volume One: 1897-1948, (Toronto: Lester \& Orpen Dennys, 1989), p. 300.
} 
services, particularly the Army." ${ }^{, 32}$ At that time, the approved strength of the Army was 25,000 and 16,100 for the RCAF. If the air force was to be responsible for a larger part of Canadian defence, this should be reflected in the number of personnel made available to it. The Committee decided to consider this disparity when reviewing current programmes from the Services. ${ }^{33}$

Given the implications of a defensive agreement with the United States, it was reasonable that Canadian politicians wanted to ensure that adequate political oversight was provided to the military. The Cabinet emphasized that the ongoing joint planning activities ought to be understood by the Canadian and American military not to imply any commitments on behalf of the Canadian government until such time as the political level was engaged. Until political approval was obtained, the planning activities were simply a means of exploring options. As a result, on 25 November, direction was provided to the Chiefs of Staff that planning could proceed with development of the Basic Security Plan and its appendices, but that neither the planners nor the Chiefs of Staff had the authority to agree on any implementation measure. ${ }^{34}$ This was the sole domain of the elected government.

On 9 January 1947, the Secretary of State for External Affairs, Louis St. Laurent, reported to the Cabinet Defence Committee on discussions held with American representatives. Although non-committal and exploratory in nature, they were meant to "dispel any impression that Canada was reluctant to undertake practical defence measures in co-operation with the United States". Another purpose of the discussions was "to

\footnotetext{
${ }^{32}$ Ibid., para 8, p. 5.

${ }^{33}$ Ibid., para 17.

${ }^{34}$ DND, DHH 193.009 (D53), Box 1, 1946, Papers and Meetings, Chiefs of Staff Committee, Minutes of the $371^{\text {st }}$ Meeting, held on 25 November 1946, p. 1.
} 
reassure Canadian representatives as to the scale and urgency of the undertakings visualized by the U.S. government which were rather less than had been anticipated." ${ }^{.35}$ St. Laurent also observed that there was no substantive difference of opinion about the joint plans being developed between the Canada and the United States. The American representatives did, however, identify the importance of American home defence plans as part of their overall global strategy. The United States itself had to be secure before embarking on foreign operations. ${ }^{36}$ This indicated that the Basic Security Plan had a major role in American domestic and foreign operations.

St. Laurent went on to describe discussions about what preliminary joint measures could be undertaken in the Canadian north. Although planning was still ongoing, the Americans asked that some work related to the air defence scheme be started immediately. This consisted of research on air warning equipment, the survey of airfield sites and training for air defence duties. Work in these areas would provide the opportunity to implement the Air Interceptor and Air Warning Appendix of the Basic Security Plan at an earlier point than if the two countries waited for the full plan to be developed. The Americans also requested that several general planning activities be continued, including mapping programmes, weather coverage, navigational support and joint testing. Work in these areas had to proceed in order to provide the support needed for air interception to take place. St. Laurent reported that agreement on these issues had been reached. ${ }^{37}$

\footnotetext{
${ }^{35}$ LAC, RG 2, Vol 2748, Vol 1, Minutes of a Meeting of the Cabinet Defence Committee, held in the Privy Council Chamber, Thursday, January $9^{\text {th }}$, p. 2 , para 5.

${ }^{36} \mathrm{Ibid}$.

${ }^{37}$ Ibid., pp. 2-3, para 5.
} 
The Secretary of State for External Affairs also reported on discussions related to the division of costs for the various joint defence projects. Agreement was reached with the Americans that, since it was too early to develop precise accounting of respective expenses, it was better to come forward with annual estimates, which could be reviewed by national financial authorities. ${ }^{38}$ This would allow the governments to maintain close track of the huge expenditures associated with the Basic Security Plan. The Cabinet Defence Committee expressed its support for the idea. Moreover, in view of the impact of these financial commitments on the overall Canadian budget, the committee decided to release a public statement about Canadian-American defence cooperation. ${ }^{39}$

The ongoing political engagement with the services caused Claxton to re-examine the relationship between the Cabinet Defence Committee and the Chiefs of Staff Committee. The planning activities in progress involved frequent briefings by the Chiefs of Staff to the political leadership and Claxton wanted to define formally the military's roles and responsibilities. On 31 January 1947, he brought before his political colleagues the following recommendations on changes to the Chiefs of Staff Committee terms of reference:

To advise the Minister of National Defence and the Cabinet Defence Committee on matters of defence policy and to prepare strategic appreciations and military plans as required.

To be responsible for co-ordinating the efforts of the Armed Services in fulfilment of a single defence policy.

To be responsible for overall policy direction of joint Service organizations, establishments and operations.

\footnotetext{
${ }^{38}$ Ibid.

${ }^{39}$ Ibid., para 8, p. 4.
} 
To investigate and consider in common all matters which may be referred to the Committee by the Minister of National Defence or the Cabinet Defence Committee. ${ }^{40}$

Claxton advocated continuation of the practice of including civilian officials at Chiefs of Staff Committee meetings when matters not of a purely military nature were being discussed. He also wanted the authority to chair these meetings at his discretion. The Cabinet Defence Committee endorsed these changes. ${ }^{41}$

At the next meeting of the Cabinet Defence Committee, on 11 February 1947, amendments were made to the approval process for defence plans. The Minister of National Defence outlined the current practice, which required the service Chiefs to submit all joint plans to the Cabinet Defence Committee for approval. This was being done for threat appreciation and the Basic Security Plan, as well as implementation programmes. As a result, the Chiefs of Staff were often before the Cabinet Defence Committee. Claxton argued that the Basic Security Plan was a contingency for the American and Canadian governments to put into action in the event of an emergency. As such, the organization, manpower and facilities identified in the plan were not influenced by currently available resources and "acceptance of the plan by either country was not to be construed as a commitment to provide such resources." Implementation plans, however, related to preparatory actions required during peacetime in order for the plan to be successful and implied the commitment of money and manpower. ${ }^{42}$

\footnotetext{
${ }^{40}$ LAC, RG 2, Vol 2748, Vol 2, Minutes of the Twenty-seventh Meeting of the Cabinet Defence Committee held in the Privy Council Chamber on Friday, January $31^{\text {st }}, 1947$, para 9, p. 3.

${ }^{41}$ Ibid., paras 9-10, p. 4.

${ }^{42}$ LAC, RG 2, Vol 2748, Vol 2, Minutes of the Twenty-eighth Meeting of the Cabinet Defence Committee held in the Privy Council Chamber on Tuesday, February $11^{\text {th }}, 1947$, para 10, pp. 3-4.
} 
Claxton wanted to provide the Chiefs of General Staff Committee with the authority to deal with issues within their areas of professional competence, which included the creation of defence plans. The political level had to be engaged, but he wanted to avoid this happening too soon. He asked the Cabinet Defence Committee to approve:

(a) that the Appreciation and Basic Security Plan (with appendices) should not be treated as documents which require acceptance (or rejection) by the governments; the Basic Security Plan to be regarded as a joint defence plan designed to ensure the security of the North American continent, agreed between the Canadian and United States Chiefs of Staff; and,

(b) that the Chiefs of the Staff Committee (with appropriate civilian officials) be responsible for recommending the degree, sequence and rate of implementation of the agreed plan, such "implementation programmes" to be submitted from time to time for decision by the government. ${ }^{43}$

The Chief of the General Staff provided some assurance to the politicians that these changes would work. He noted that the Cabinet Defence Committee could be kept informed of developments through annual briefing on the Appreciation and Basic Security Plan. To facilitate political oversight, he promised that the Chiefs of Staff would provide consolidated implementation programmes in time to allow their consideration in conjunction with the annual service estimates. The Cabinet Defence Committee discussed and accepted these changes. ${ }^{44}$

The devolution of responsibility for the Basic Security Plan from the Cabinet Defence Committee to the Chiefs of Staff demonstrated major changes in civil-military relations within postwar Canada. The political and military levels were coming to

\footnotetext{
${ }^{43}$ Ibid., p. 4. The additional authority provided to the services with these changes was a form of empowerment. With this, it is possible to begin using the Millet, Murray and Watman methodology to assess the effectiveness of the services.

${ }^{44}$ Ibid., para 11-12, p. 4.
} 
agreement about the division of labour. This step firmly placed the military in charge of the planning process, with the government retaining responsibility for control over spending and resources, and placed trust in the military not to commit the Canadian government to inappropriate activities. The new procedures facilitated interaction between the civil and military sectors, as the Chiefs of Staff provided regular updates to the politicians. This allowed the government to be informed of problems as they arose and provided the opportunity for ongoing guidance for the military. The development of the implementation programme also served as a means of keeping the government informed of the financial ramifications of military plans, with the Basic Security Plan serving as the test case. This collaborative approach with the government would serve the military well, including the RCAF as it prepared air defence measures.

\section{The Military Cooperation Committee}

In December 1945, the Permanent Joint Board on Defence established the joint Canadian-American MCC to do much of the work associated with the Basic Security Plan. ${ }^{45}$ It consisted of army, navy and air force representatives from each country, as well as government officials. This committee met frequently to write the different components of the plan and was responsible for developing the framework for the air defence of North America, reconnaissance, military intelligence and a response force for enemy landings in Canada or the United States. It produced much of the Basic Security Plan documentation reviewed by the Cabinet Defence Committee. The MCC also reported to the Permanent Joint Board on Defence, which was led by senior political

\footnotetext{
${ }^{45}$ DND, DHH 193.009 (D53), Box 1, Papers and Meetings, Chiefs of Staff Committee, Minutes of the $366^{\text {th }}$ Meeting of the Chiefs of Staff Committee, dated 8 October 1946.
} 
appointees from both countries. In Canada's case, this appointee was former Chief of the General Staff and former Minister of National Defence Andrew McNaughton, who had strong ties to the Liberal government in Ottawa.

One of the first activities by the committee was the development of an approval process for the Basic Security Plan and its appendices. This process was designed to allow frequent opportunities for political and military guidance on plan content. As a result, as each appendix was developed, it was briefed a number of times to the Permanent Joint Board on Defence, the Chiefs of Staff Committee and the Cabinet Defence Committee. The MCC asserted that each appendix was an integral part of the Basic Security Plan, which detailed the personnel, facilities and materiel necessary to respond to war. It was not intended to define peacetime requirements. Therefore, negotiations were required between the Canadian and American governments concerning whether and how much of the Basic Security Plan had to be implemented ahead of time. No part of the Plan could be interpreted as being in force before the Canadian or American governments had expressly provided support for it.

The Canadian and American military were aware that it was unlikely that sufficient warning of attack would be provided to allow lengthy preparations. This resulted in a requirement to take steps in peacetime that would allow defence forces to be ready on short notice in time of emergency. This Committee sought authority to make recommendations on the "degree, sequence and rate of implementation of any agreed Appendix when considered necessary and these recommendations form separate 
submissions to higher authority."46 They asserted that should "it become evident during the course of the security planning that certain measures should be initiated without delay, recommendations to that effect be made to higher authority without waiting for all or any of the Appendices to the Basic Security Plan to be completed." ${ }^{47}$ The Canadian government and the Chiefs of Staff Committee supported this approach ${ }^{48}$ and this eventually led to the staggered implementation of the Basic Security Plan.

In late January 1947 , an immediate result of this decision was the recommendation by the MCC that measures be taken to implement segments of the evolving Air Interceptor Plan. Specifically, the committee called for surveys to be conducted for future air field, headquarters and early warning sites. Associated with this, it was recommended that a number of existing air fields and early warning sites be retained at least on a caretaker basis, until such times as a decision was made about which of these sites should be included in the Basic Security Plan. The committee also asked that a joint programme for the development and testing of radar equipment in the northern latitudes be implemented. ${ }^{49}$

Although these measures represented a fraction of the overall work that would be required for a North American defence system, the Chief of the General Staff was already worried about the costs. At a Chiefs of Staff Committee meeting, Foulkes indicated a preference to spread implementation of these recommendations over two years. The

${ }^{46}$ DND DHH 193.009 (D53), Box 3, file number T.S. 15-9-45, entitled "Submission of Appendices of the Basic Security Plan to Higher Authority", dated 30 December 1946,enclosure dated 11 December 1946, pp. 1-2, which is attached to file number CSC 5-1, Chiefs of Staff Committee, dated 31 December 1946.

${ }^{47}$ Ibid, p. 2

${ }^{48}$ DND, DHH 193.009 (D53), Box 3, extract from minutes of the $375^{\text {th }}$ Meeting of the Chiefs of Staff Committee, held on 7 January 1947, minute sheet dated 11 January 1947, p. 1.

${ }^{49}$ DND, DHH 193.009 (D53), Box 2, 1947, Papers and Meetings CGS - Copies of Memoranda, Vol 63, February 1947, letter entitled Immediate Measures Required - Air Defence Appendix of the Basic Security Plan, dated 31 January 1947. 
Chief of the Air Staff argued that such factors as weather had to be considered, since surveys could be completed only during the summer. He strongly recommended that the proposed measures be carried out during the current year. The Chiefs of Staff Committee agreed with the Chief of the Air Staff and decided to forward the MCC's recommendations to the Cabinet Defence Committee ${ }^{50}$ for approval, which was provided on 11 February $1947 .^{51}$

In October 1947 the Chiefs of Staff Committee briefed the Cabinet Defence Committee on the MCC's work. With the progress that had been made with the plan, authority was sought to begin some additional preliminary implementation measures, including research and tests, training exercises and standardization of arms and operating procedures. The Chief of the Air Staff highlighted those measures within the RCAF's domain, the most important of which was the creation of an experimental air warning system within Canada. This system was intended to eventually become part of a transcontinental network for air defence and had an initial estimated cost of $\$ 4.7$ million. Other elements of the air force programme included creation of a weather analysis centre, locating sites for airfields and radar stations, and installation of additional navigation aids. $^{52}$

The Chief of the General Staff took this opportunity to obtain guidance on issues raised by American representatives on the MCC. The Canadian government was asked to provide feedback on whether it believed North America would be seriously attacked from

\footnotetext{
${ }^{50}$ DND, DHH 193.009 (D53), Box 2, 1947, Papers and Meetings CGS - Copies of Memoranda, Vol 63, February 1947, Extract from Minutes of $378^{\text {th }}$ Meeting of the Chiefs of Staff Committee, held $4^{\text {th }}$ February 1947, pp. 1-2.

${ }^{51}$ DND, DHH 193.009 (D53), Box 2, 1947, Papers and Meetings CGS - Copies of Memoranda, file Memoranda, Canada-United States Basic Security Plan, dated 13 February 1947.

${ }^{52}$ LAC, RG 2, Vol 2748, Vol 2, Minutes of the Thirty-seventh Meeting of the Cabinet Defence Committee held in the Privy Council Chamber on Tuesday, October $28^{\text {th }}$, 1947, para 3, p. 2.
} 
the air within the next ten years and, if so, when such a threat would first be considered likely. The Americans wanted to use the answers to these questions to develop a longterm assessment, which would influence when the various measures of the Basic Security Plan would be completed. This related to an important difference in approach by the two countries: the United States tended to make plans based upon a potential enemy's capabilities, while Canada typically also took into consideration the probability of an enemy's attack. ${ }^{53}$

The Chiefs of Staff accepted that a foreign aggressor could potentially launch a large air attack on North America within the next decade, but doubted it would be an allout attack. They advocated consideration of the probability of an attack when deciding what portions of the Basic Security Plan should be implemented and on what schedule. This approach allowed them to seek government funding support for costly air defence measures over a number of years rather than all at once. The Chiefs of Staff also wished to resist any attempt by the United States to develop an agreed upon, long-term study on the probability and timing of possible attack. The Secretary of State for External Affairs, Louis St. Laurent, supported the Chiefs of Staff on these points, indicating a preference for periodic assessment of the situation rather than committing to a more enduring agreement between the two countries. ${ }^{54}$ Afterwards, the Canadian Section of the MCC was able to deflect American attempts to establish a multi-year approach to Basic Security Plan implementation.

The establishment of the MCC proved important to the completion of the Basic Security Plan. In a relatively short period, this committee developed the multiple

\footnotetext{
${ }^{53}$ Ibid., para 9, pp. 3-4.

${ }^{54}$ Ibid., paras 9-10, pp. 3-4.
} 
appendices covering wide-ranging aspects of North American defence. Different plan elements were not always accepted by all members of the Chiefs of Staff Committee, but this was not necessarily reflective of the quality of work by the MCC. Inter-service rivalry about the division of funds and responsibility may have played a role in this. An important aspect of this planning process is that Canada did not automatically agree with American initiatives. Canada demonstrated that it participated in collaborative defence planning on its own terms and the MCC provided a means to resist costly or needlessly quick implementation measures for the Basic Security Plan.

\section{The Basic Security Plan}

An overview of the planning activities associated with the Basic Security Plan gives an appreciation of its scope. A February 1947 progress report to the Chiefs of Staff Committee provided an update on the status of Plan appendices related to: Air Interceptor and Air Warning; Navy/Air Striking Force; Communications; Air Navigation Aids; Air Photography, Hydrographic Survey, Mapping and Charting; Strategic Information; Arctic Tests and Experience; Meteorological Services; Anti-Submarine Measures; Anti-Aircraft Ground Defence; Army/Air Mobile Striking Force; Strategic Air Reconnaissance; and Naval Convoy and Routing. ${ }^{55}$

The Air Interceptor and Air Warning Appendix was the only plan near completion at that time, with all others still in preliminary development, which is indicative of the emphasis being placed on air defence. ${ }^{56}$ This appendix was developed under the

\footnotetext{
${ }^{55}$ DND, DHH 193.009 (D53), Box 2, 1947, Papers and Meetings, File CGS - Copies of Memoranda, Chiefs of Staff Committee, Vol 63, February 1947, Memoranda entitled Basic Security Plan - Progress of, dated 19 February 1947, enclosure Progress Report No. 2, Appendix 1.

${ }^{56}$ Ibid.
} 
assumption that it had to defend against an initial air attack without prior warning. It also assumed that the Soviets could use atomic weapons after 1950 and biological weapons could be used at any time. The appendix also foresaw the use of short-range guided missiles against peripheral North American targets, although the possibility of airborne or ship launched missiles would extend this range. ${ }^{57}$ It included details on the potential location of 46 radar sites in Canada and another 171 in the United States, nine in Greenland and 37 in Alaska (which at that time was not yet a State). The possible location of 26 airbases in Canada and four in Newfoundland and Labrador was also identified. Furthermore, it specified the requirement for 150 fighter aircraft in Newfoundland, Labrador and Greenland, 1150 fighters in the North Atlantic Coastal Plain - Great Lakes area, 325 fighters along the Vancouver-San Diego stretch of coast line, 50 fighters in the Cameron Bay area of Canada's north and another 150 fighters in Alaska. ${ }^{58}$ Personnel requirements for the radar sites, fighter bases and headquarters for this fighter-interceptor role were estimated at 35,266 within Canada and Newfoundland and another 83,616 in the United States, Alaska and Greenland. ${ }^{59}$ Given that the approved strength for the entire RCAF was 16,100 personnel and there were few operational aircraft in service at that time, the adoption of this plan would have been a massive undertaking beyond the capabilities of the current air force. The CanadianUnited States MCC noted in April 1947 that the air interceptor and air warning aspects of the Basic Security Plan could be implemented within $2 \frac{1}{2} 2$ - four years, but recommended

\footnotetext{
${ }^{57}$ DND, DHH 193.009 (D53), Box 2, 1947, Papers and Meetings CGS - Copies of Memoranda, file Memoranda, Canada-United States Basic Security Plan, entitled "A Brief Memorandum Dealing with the Air Interceptor and Air Warning Appendix to the Canada-United States Basic Security Plan," enclosed Memorandum by the Canadian-United States Military Cooperation Committee, dated 2 April 1947, p. 6. ${ }^{58}$ Ibid., pp. 7-11.

${ }^{59}$ Ibid., p. 12.
} 
that the air defence systems be completed in "a much shorter time" due to security considerations. ${ }^{60}$

Another progress report on the Basic Security Plan was provided to the Chiefs of Staff Committee on 14 May 1947. This detailed the changes made to the various Plan Appendices, many of which were nearing completion. Air force-related appendices related to air navigation aid, strategic air reconnaissance and air photography had been drafted and the appendix on army/air mobile striking force was developing. The report indicated that there was a requirement for an additional appendix, dealing with the Canada-United States command structure and defining respective responsibilities during joint tasks in the Basic Security Plan. ${ }^{61}$ This document also provided the schedule for future meetings, which indicated the intention to complete the entire document by September 1947, which would allow the Canadian military to include Basic Security Plan-related costs in its defence estimates to the Cabinet Defence Committee in October 1947. ${ }^{62}$ But already the anticipated costs of the Basic Security Plan was a concern for the government, leading the Privy Council Office to inform the Chiefs of Staff Committee to exercise care in representing to American authorities the degree of Canadian commitment to the plan. ${ }^{63}$

The Basic Security Plan was soon completed and, by March 1948, the MCC identified implementation measures for the various appendices, including the Air

\footnotetext{
${ }^{60}$ DND, DHH 193.009 (D53) Box 2, 1947, Papers and Meetings, Chiefs of Staff Committee, Vol 68, July 1947, no file number, memorandum entitled "Air Interceptor and Air Warning Appendix to the Joint Canadian-United States Security Plan", dated 2 April 1947, pp. 1-2.

${ }^{61}$ DND, DHH 193.009 (D53) Box 2, 1947, Papers and Meetings, Chiefs of Staff Committee, Vol 66, May 1947, entitled "Progress Report No. 3", dated 14 May 1947, pp. 1.5.

${ }^{62}$ Ibid., Appendix B.

${ }^{63}$ DND, DHH 193.009 (D53) Box 2, 1947, Papers and Meetings, Chiefs of Staff Committee, Vol 68, July 1947, Extract from Minutes of the $390^{\text {th }}$ Meeting of the Chiefs of Staff Committee, held 13 May 1947, p. 1.
} 
Interceptor and Air Warning appendix. ${ }^{64}$ Approval of the plan was now in the hands of the military and political leadership. Despite the intention to have completed this for the previous September, full costing for the different aspects of the plan had not been worked out as yet. Nevertheless, it was obvious that the plan was going to place a large demand upon the public purse. The nature of the implementation measures and their impact will be explored as part of the next chapter.

The Basic Security Plan was the primary impetus behind the expanded role that developed for the RCAF and resulted in the largest peacetime commitment of military personnel, resources and funds ever in Canada. No other single initiative comes close to it. For the air force, this plan eventually led to the establishment of four flight training units, ${ }^{65} 26$ Regular RCAF fighter units, ${ }^{66}$ eight Auxiliary flying units, ${ }^{67}$ and two Surfaceto-Air Missile squadrons. ${ }^{68}$ Eight Regular RCAF Stations were constructed or modified to support air defence operations. ${ }^{69}$ Thirty Regular and 14 Auxiliary Air Control and Warning Squadrons were spread across the country to direct the fighters. ${ }^{70}$ These Air Control and Warning Squadrons were supported by 13 Radar Squadrons, ${ }^{71}$ which

\footnotetext{
${ }^{64}$ DND, DHH 193.009 (D53), Box 3, 1947-1948, Papers and Meetings, Chief of Staff Committee, file March 1948, CSC Miscellaneous, letter file number CSC 3-4-6, dated 23 March 1948.

${ }^{65}$ Don Nicks, John Bradley and Chris Charland, The Air Defence of Canada, 1948-1997 (Gilmore: Ottawa, 1997), pp. 57-59. These included No. 1 (Fighter) Operational Training Unit, Sabre Transition Unit, No. 3 All Weather (Fighter) Operational Training Unit and No. 6 Strike/Reconnaissance Operational Training Unit.

${ }^{66}$ Ibid., pp. 60-84. Regular RCAF fighter units formed as part of North American air defence include Squadrons 403, 409, 410, 413, 414, 416, 417, 419, 421, 422, 423, 425, 427, 428, 430, 431, 432, 433, 434, $438,439,440,441,444$, and 445 . All of these did not exist at the same time and many also had service in Europe.

${ }^{67}$ Ibid., pp. 59-83. These consisted of Squadron 400, 401, 402, 411, 420, 424, 442 and 443.

${ }^{68}$ Ibid., pp. 84-85. This included 446 and 447 Squadrons.

${ }^{69}$ Ibid., 59-84. Stations were located at St. Hubert, PQ, Comox, BC, Cold Lake, AB, Bagotville, PQ, North Bay, ON, Chatham, NB, and Val D'Or, PQ.

${ }^{70}$ Ibid., pp. 99-125.

${ }^{71}$ Ibid.
} 
managed over 200 pieces of radar $^{72}$ at up to 66 different locations. ${ }^{73}$ The challenge of building a cross-country chain of radar sites and airbases was massive and represented a major achievement. Military planners deserve recognition for the comprehensiveness of their work and the professionalism that allowed them to carry it out.

\section{Air Defence and Inter-Service Rivalries}

When the air defence requirements of the Basic Security Plan were first briefed to the Cabinet Defence Committee in November 1946, the Chief of the Air Staff expressed concern about its scope and cost, while the Chief of the General Staff indicated support for it. ${ }^{74}$ Prime Minister Mackenzie King followed this up with comments about the need to reassess the relative strengths of the services, especially the air force. ${ }^{75}$ Soon thereafter, the two service chiefs had a change in heart, with Leckie promoting the merits of the air defence plan and Foulkes suddenly less supportive. Inter-service rivalry for budget, resources and prestige must be considered a major cause of the conflict that broke out between these two individuals and their respective services.

When the completed Air Warning and Air Interceptor Appendix of the Basic Security Plan was first submitted to the Chiefs of Staff Committee in June 1947, it was not immediately embraced by all. Air Marshal Leckie opened by outlining his belief that this segment of the Basic Security Plan "constituted a satisfactory and adequate plan for the air defence of Canada". He acknowledged that implementation plans for it could not proceed until there was an overall plan. The Director General of Defence Research

\footnotetext{
${ }^{72}$ Ibid., p. 25.

${ }^{73} \mathrm{http}: / /$ www.lswilson.ca/dewline.htm.

${ }^{74}$ LAC, RG 2, Vol 2748, Vol 1, Minutes of the Twenty-fourth Meeting of the Cabinet Defence Committee, held in the Privy Council Chamber, on Wednesday, November $13^{\text {th }}, 1946$, para 4-6, pp. 2-3.
} 
sounded a caution, suggesting that while the plan addressed past and present requirements, technical advances would soon render it obsolete in many respects. Therefore, he believed that there was a requirement for planners to consider means of adopting and incorporating technological advances as they became available. ${ }^{76}$

Lieutenant-General Charles Foulkes responded with a seven page criticism of the Air Interceptor and Air Warning Appendix, observing that strategic appreciations had found that there likely would not be a threat to North America for ten years. This was contrary to his opinion the previous November, at which time he argued that defensive measures were required because of the vulnerability to air attack. ${ }^{77}$ He believed that the appendix focused on the defensive rather than the offensive and that it did not consider the threat from missiles. Foulkes also expressed concern that the cost of maintaining an elaborate defensive system against surprise attack would damage the national economy. Instead, he called for the creation of balanced forces capable of offensive operations and a scaled down version of the air defence plan with fewer installations that would be colocated with existing northern facilities such as Hudson's Bay Company posts. ${ }^{78}$ Following extended discussion, the Chiefs of Staff Committee agreed to defer any decision on this segment of the Basic Security Plan pending further consideration. ${ }^{79}$

\footnotetext{
${ }_{75}^{75}$ Ibid., para 8, p. 5.

${ }^{76}$ DND, DHH 193.009 (D53) Box 2, 1947, Papers and Meetings, Chiefs of Staff Committee, Vol 68, July 1947, Extract from Minutes of $392^{\text {nd }}$ Meeting of the Chiefs of Staff Committee, Held 3 June 1947, p. 1.

${ }^{77}$ LAC, RG 2, Vol 2748, Vol 1, Minutes of the Twenty-fourth Meeting of the Cabinet Defence Committee, held in the Privy Council Chamber, on Wednesday, November $13^{\text {th }}, 1946$, para 6, p. 3.

${ }^{78}$ Document entitled "Observations on Air Warning and Air Interceptor Appendix", no file number, by Lieutenant-General Charles Foulkes, Chief of the General Staff, dated 25 June 1947, attached to DND, DHH, 193.009 (D53), Box 2, Papers and Meetings, Chiefs of Staff Committee, Vol 68, July 1947, memorandum CSC 3-1, dated 11 July 1947.

${ }^{79}$ Extract of Minutes of $394^{\text {th }}$ Meeting of the Chiefs of Staff Committee, dated 28 June 1947, attached to DND, DHH, 193.009 (D53), Box 2, Papers and Meetings, Chiefs of Staff Committee, Vol 68, July 1947, memorandum CSC 3-1, dated 11 July 1947.
} 
Leckie responded to Foulkes' criticism by indicating that the Air Interceptor and Air Warning Plan was designed to protect not just Canada, but North America as a whole. He argued that government had already accepted the need to give air defences top priority and that the costs, which were as yet unknown, would not be prohibitive. Leckie argued that missile technology was not advanced sufficiently to threaten North America at present and that the plans were flexible enough to allow modification in the event of changes to the nature of the threat. He warned against "red herrings" confusing government leaders and recommended that the Air Interceptor and Air Warning Appendix to the Basic Security Plan be approved in principle. ${ }^{80}$ In observing this back and forth posturing by the heads of the army and air force, A.D.P. Heeney, Secretary to the Cabinet, advocated that the Chiefs of Staff simply decide "whether or not the plan proposed was the best plan for the defence of Canada ... or whether, on the other hand, it was subject to Service qualifications along the lines of the views expressed by the Chief of the General Staff". ${ }^{11}$

Foulkes' objections did not stop a new Joint Appreciation and the Basic Security Plan from going forward. During his absence on 15 July $1947,{ }^{82}$ the Chiefs of Staff Committee forwarded and recommended to the Cabinet Defence Committee that the recent Joint Appreciation and the Basic Security Plan be approved. ${ }^{83}$ This

\footnotetext{
${ }^{80}$ Document entitled "Observations on Air Warning and Interceptor Appendix", no file number, by Air Marshal Robert Leckie, Chief of the Air Staff, dated 8 Jul 1947, attached to DND, DHH, 193.009 (D53), Box 2, Papers and Meetings, Chiefs of Staff Committee, Vol 68, July 1947, memorandum CSC 3-1, dated 11 July 1947.

${ }^{81}$ Extract of Minutes of $394^{\text {th }}$ Meeting of the Chiefs of Staff Committee, dated 28 June 1947, attached to DND, DHH, 193.009 (D53), Box 2, Papers and Meetings, Chiefs of Staff Committee, Vol 68, July 1947, memorandum CSC 3-1, dated 11 July 1947, p. 3.

${ }^{82}$ Lieutenant General C.C. Mann was acting in Foulkes' place.

${ }^{83}$ DND, DHH 193.009 (D53), Box 2, 1947, Papers and Minutes, Chiefs of Staff Committee, Vol 68, July 1947, enclosure entitled "Memorandum for the Cabinet Defence Committee: Canada-United States Joint
} 
recommendation was tempered by comments indicating that the Canadian intelligence community did not have its own sources and was unable to assess the value of the intelligence provided by other sources. The Chiefs of Staff Committee expressed reservations about, but was unable to refute, the Appreciation's claim that a potential enemy could produce atomic weapons in operational quantities within three to five years. The Committee also suggested that the Appreciation's assertions overstated the threat of land-based missiles within five years and the danger posed by internal subversive elements. $^{84}$

Regarding the Basic Security Plan, the Chiefs of Staff expressed the opinion that, in view of the size and extent of the vulnerable areas to be protected respectively in Canada and the United States, the lead on air defence should be taken by the United States. Canada would act as a secondary partner. The requirement to standardize on American equipment was another reason for Canada to be in a subordinate position. Canadian sovereignty would be protected and the costs to Canada offset by permitting the United States to locate equipment on Canadian territory, but under Canadian control. The costs to Canada would be determined according to the "size and extent of the vulnerable areas to be protected and the financial and manpower resources of each country." Furthermore, while there appeared to be no immediate threat of attack by an enemy, the magnitude and duration of the work associated with building an air defence systems meant that approval should be provided by the Cabinet Defence Committee for the Basic Security Plan and Joint Appreciation in order to allow planners to proceed. ${ }^{85}$

Appreciation and Basic Security Plan; comments thereon by the Chiefs of Staff', dated 15 July 1947, p. 3, to CSC 5-1-2, entitled "Canada-U.S. Joint Appreciation and Basic Security Plan", dated 11 July 1947.

${ }^{84}$ Ibid., p. 2.

${ }^{85}$ Ibid., p. 3. 
The MCC also responded to the Chiefs of Staff Committee about Foulkes' criticism that the Basic Security Plan was overly defensive in nature, did not sufficiently provide for an offensive capability and was too costly. MCC noted that their terms of reference gave priority to defensive measures over offensive and argued that they had considered the need to be able to take the battle to an enemy, since defensive units could also mount an attack. This Committee indicated that their focus had been on preparing an overall plan, and that the relative costs to Canada and the United States was a matter of negotiations between governments and not in their domain to resolve. They advised that it would be best to review the cost of the Basic Security Plan only after the entire document was complete, at which time the governments would be better situated to consider all relevant factors, including how these plans meshed with those of other nations, such as the United Kingdom. ${ }^{86}$

The Acting Chief of the General Staff, Lieutenant General C.C. Mann, noted that he had reviewed General Foulkes' and Air Marshal Leckie's comments on the Air Interceptor and Air Warning Appendix. He found that, while their opinions seemed to have some common ground, Foulkes had introduced considerations about offensive capabilities which were outside the scope of the appendix. He suggested that Foulkes' comments need not hold up approval of the appendix, but expressed a preference that such a decision be deferred until Foulkes could be present to participate in discussion. The Chief of the Naval Staff agreed and the Committee decided to put off approval of the

${ }^{86}$ DND, DHH 193.009 (D53) Box 2, 1947, Papers and Meetings, Chiefs of Staff Committee, Vol. 68, July 1947, Extract from Minutes of the $396^{\text {th }}$ Meeting of the Chiefs of Staff Committee Held on 17 July 1947, p. 1 , 
Air Interceptor and Air Warning Appendix until the Chief of the General Staff was present. $^{87}$

Before the return of the Chief of the General Staff, another progress report on the Basic Security Plan and Joint Appreciation was provided to the Chiefs of Staff Committee, no doubt influenced by the Chiefs of Staff comments on 15 July 1947 to the Cabinet Defence Committee. This report indicated that the MCC had reviewed the Joint Appreciation and Basic Security Plan and found that "there are no changes of substance which warrant revision at this time of either the appreciation or the plan." ${ }^{, 88}$ This report also indicated that all Basic Security Plan appendices were approaching completion. ${ }^{89}$

On 15 July, the Chiefs of Staff had expressed concern that the Joint Assessment somewhat overstated the degree and nature of the threat. In a move that apparently conflicted with this, in early September the Service Chiefs indicated that while changes might not be warranted in the Basic Security Plan itself, they would not accept that recent deterioration in the world situation ${ }^{90}$ did not necessitate a corresponding change in the Joint Appreciation. ${ }^{91}$ The reasons for this change of heart about the threat situation seems directly attributable to the recent addition to Chiefs of Staff Committee meetings

\footnotetext{
${ }^{87}$ Ibid., p. 4.

${ }^{88}$ DND, DHH 193.009 (D53) Box 2, 1947, Papers and Meetings, Chiefs of Staff Committee, Vol. 68, August 1947, letter J.P.C. 3-0, entitled "Chiefs of Staff Committee - Joint Planning Committee, Progress Report Number 4", dated 26 July 1947, p. 1.

${ }^{89}$ Ibid., Appendix A.

${ }^{90}$ Events during the July-early September, 1947 period included the acceptance of the Marshall Plan in western Europe but not eastern Europe, which effectively divided Europe into two spheres of influence; the arrival of the ship Exodus in Palestine on 18 Jul, sparking confrontation with British authorities; the independence of Pakistan and India from Great Britain, which led to widespread violence and initial conflict over Kashmir during August; a military coup in Greece on 16 August; Communists taking power in Hungary on 31 August.

${ }^{91}$ DND, DHH 193.009 (D53) Box 2, 1947, Papers and Meetings, Chiefs of Staff Committee, Vol. 68, Extract from Minutes of the $400^{\text {th }}$ Meeting of Chiefs of Staff Committee held on 4 September 1947, para 24-26.
} 
of Lester Pearson as a representative for the Department of External Affairs. At the 4

September meeting, Pearson alone had indicated that he:

found it difficult to accept a statement that there was no deterioration in the world situation during the past year. While the present situation might not involve a change in the plan itself, the emphasis to be placed on defence should be governed by the international situation, and such improves or deteriorations as they occur. $^{92}$

At this same meeting, Foulkes sought to resolve his disagreement about the Basic Security Plan's Air Interceptor and Air Warning Appendix, which had already been forwarded to the Cabinet Defence Committee. He reiterated his concerns about the lack of offensive operations contained in the Basic Security Plan and indicated that it must be examined not only on its own merits, but also with a view towards the implications for national sovereignty. He believed that the plan should be reviewed with the intent of ensuring that American presence on Canadian soil was minimized. Foulkes advocated a cautious approach to implementation due to financial concerns, expressing a preference for the initial emphasis to be placed on training of personnel, reconnaissance, surveys, and the development of radar. As one means of reducing costs, he suggested that the United States be encouraged to develop mobile radar that did not require permanent positioning in Canada, but could be deployed into Canada when required. ${ }^{93}$ He expressed the opinion that planners, as well as the Cabinet Defence Committee, should be informed that the Canadian Forces would not accept a purely defensive role and that the defence of North American airspace must be shared between Canada and the United States. ${ }^{94}$

\footnotetext{
92 Ibid., para 25.

${ }^{93}$ Ibid., para 3.

${ }^{94}$ Ibid., para 4.
} 
Air Marshal Wilf Curtis, who succeeded Leckie as Chief of the Air Staff on 1 September, suggested that his predecessor's observations had been motivated by the desire to avoid, as far as possible, the presence of American personnel in Canada during peacetime. Curtis also argued that some construction could be done economically and was required ahead of time, such as runways and communications lines. He acknowledged that there was a distinction between approving and implementing the Basic Security Plan, which was a nuance that the MCC, the Permanent Joint Board on Defence and American authorities had to understand. Implementation measures had to be approved as part of the annual budgetary planning process. ${ }^{95}$ The Chiefs of Staff Committee, including Foulkes, eventually agreed to endorse the Air Interceptor and Air Warning Appendix as part of the Basic Security Plan, with an implementation program targeting initial measures during the $1948-49$ fiscal year. ${ }^{96}$ Curtis represented air force interests well and often displayed the interpersonal skills to overcome opposition to RCAF initiatives.

This extended disagreement between the Army and the Air Force did not mean that they could not collaborate. A different Basic Security Plan appendix required the two services to work together for domestic security. The Mobile Striking Force plan used air, airborne, amphibious and naval striking forces to counter possible enemy landings, referred to as lodgements, in the Canadian north. This plan foresaw the possibility of enemy forces, with a likely strength of a few hundred men, launching

\footnotetext{
${ }^{95}$ Ibid., para 5.

${ }^{96}$ Ibid., para 10.
} 
diversionary attacks as part of a larger offensive operation. ${ }^{97}$ Possible missions of such enemy forces included destruction of Canadian or American military installations, radar or meteorological sites, and air navigation facilities, the establishment of weather, communications, missile guiding or early warning stations, or even the delivery of saboteurs. ${ }^{98}$ While the main response to such a threat would come from the army, the distances and isolation involved in possible lodgement locations resulted in a requirement for tactical transport aircraft capable of operations in Northern areas, as well as an air force capability to support airborne operations and provide tactical fire support. ${ }^{99}$ This Basic Security Plan appendix identified the requirement for a total of six troop carrier squadrons available, with three American squadrons situated in Alaska and another three, provided by the RCAF, located in central Canada. ${ }^{100}$ This at least appeared to provide a forum for Army/Air Force collaboration and mutual support, which was the case at first.

A reasonable interpretation of the disagreement between the Canadian Army and the Royal Canadian Air Force is that it was influenced by organizational interests. Janowitz and Abrahamsson held that a professional military competes for resources from civil authorities by acting as an interest group. Following Prime Minister Mackenzie King's questioning of the relative distribution of strength between the services in view of the Basic Security Plan, Foulkes challenged first Leckie and then Curtis about air defence requirements. In doing so, he was simply protecting army interests. From the Janowitzian perspective, the behaviour of the air force showed an increase in

\footnotetext{
${ }^{97}$ DND, DHH 193.009 (D53), Box 3, 1947-1948, Papers and Meetings, Chief of Staff Committee, file March 1948, Extract from Minutes of the $417^{\text {th }}$ Meeting of the Chiefs of Staff Committee, Held on 2 March 1948, enclosure Canada-United States Basic Security Plan, Appendix I, Mobile Striking Force, p. 1.

98 Ibid., p.2.

${ }^{99}$ Ibid., pp. 2-3.

${ }^{100}$ Ibid., p. 4.
} 
"corporateness", by presenting an increasingly united front against others. The RCAF had the opportunity to become a major player in Canadian defence and it actively pursued it.

Conclusion

It is difficult to over-emphasize the importance of the Basic Security Plan for the RCAF. This plan explicitly recognized the air threat from the Soviet Union as a matter of pressing national concern for Canada and the United States. The response to this threat provided the basis for the sustained expansion of the air force.

An important element in the development of the Basic Security Plan was the engagement of senior political leadership in the process. The Cabinet Defence Committee was frequently briefed on the plan and provided guidance to keep matters within acceptable boundaries. The government also entered into direct negotiations with the United States government, which allowed potentially contentious issues, such as the presence of American troops on Canadian soil, to be resolved at the political level. In the past, much of the contact between the military and political leadership appeared to centre on budget related matters. The increased dealings between the two fostered a more comprehensive relationship, bringing politicians into contact with a wide range of issues, such as the nature of and requirement for an air defence system for the country. With the enhanced awareness of defence issues that resulted, the services were better able to obtain a sympathetic hearing when seeking support for more personnel, equipment and money. The RCAF was to benefit from this. 
The Basic Security Plan enjoyed broad support from within and outside the military. Political effectiveness facilitated this. The Cabinet Defence Committee's decision to give the service chiefs the responsibility for defence planning demonstrated an emerging trust relationship between the political and military leadership. The RCAF played an important role in this. An example of air force political effectiveness related to the ability to overcome Foulkes opposition and convince the politicians that RCAFrelated measures within the Basic Security Plan should be approved.

Development of the Basic Security Plan also affected the relationship between the Canadian Army and the RCAF. Foulkes' stubborn opposition to the Air Interceptor and Air Warning appendix of the Basic Security Plan can be viewed through the prism of inter-service rivalry, as any enhancement to the RCAF's role were seen as threatening the status of and availability of resources to the Army. Similarly, Leckie's and Curtis' active support for this appendix and other air-related appendices to the plan was likely influenced by their understanding of how their implementation would benefit the air force. Air force leadership recognized the organizational self-interests involved in the adoption of the Basic Security Plan and evolving professionalism allowed them to pursue it.

Technology provided both problems and solutions for the RCAF. As mentioned by the Director General of Defence Research, there was a basis for concern that the Air Interceptor and Warning Appendix addressed only past and present requirements, and that technical advances would soon render the aircraft and infrastructure built as part of North American air defence obsolete. Yet technology also supplied some answers for the air force. More capable aircraft, radar developments that eventually provided coverage 
across Canada and advances in communications facilitated the evolution of a more powerful and competent RCAF.

Against the backdrop of an intensifying Cold War, planners set out to design a scheme for North American defence. With the Basic Security Plan, which was completed and approved over approximately three years, they accomplished this goal. Since this plan was the result of a joint effort with the Americans, the success of the planning efforts cannot be attributed only to the Canadian service planners, but they certainly played their part. The RCAF gained experience during the development of the plan and was exposed to processes that worked. This included the presence and articulation of a credible threat, identification of a suitable response, and the engagement and buy-in of political leadership. The challenge now was for air force planners to continue to develop professionally and to apply these lessons on their own.

The Cold War played an important role as military planning evolved. The threat posed by the Soviet Union provided the main focus of military plans and directly affected the form and function of the Canadian military. The Cold War provided the justification for the RCAF expansion across the country and a significant operational role for the air force. It caused the RCAF to assume increasing responsibility for the air defence of Canada through the deployment of interceptors supported by a chain of radar stations. Other air force roles brought about or strengthened by the Cold War include strategic air reconnaissance, air transportation of the Army in support of the Mobile Striking Force, contributing to the creation of a trans-national meteorological service, development and deployment of air navigation aids across Canada, air photography, support to antisubmarine missions and participation in a naval/air striking force. Fulfilling these roles 
would not take place overnight, as implementation of the Basic Security Plan would take a long time. But it was manifestly obvious that, in order to respond to the Cold War threat, the RCAF had to grow.

In summary, planning activities associated with the Basic Security Plan were a significant factor in the evolution of the Royal Canadian Air Force. Planners were effective in identifying goals and then achieving them, which held promise for the future of the air force. Although there were reasons for initial postwar concerns by the air force about its peacetime role and composition, Canada's response to the Cold War could put these to rest. 


\section{CHAPTER FOUR:}

\section{REBUILDING THE RCAF, 1947-1948}

RCAF leaders approached the $1947-48$ period with apprehension. Following the end of the Second World War, they had overseen the demobilization of the air force and essentially all of their operational capabilities had been cut. 1947, indeed, was to begin with further downsizing and budgetary reductions. However, as negotiations and planning activities with the United States for the Basic Security Plan progressed, there were reasons to believe that the air force would have an increased defence role. The growing threat from Soviet airpower contributed to this.

This chapter will examine the planning and related activities of the RCAF during the latter part of the 1940s. It will begin by examining the cause and results of cutbacks in early 1947 and assess the state of the air force. A review of the implications for the Basic Security Plan follows, the development of which was described in the previous chapter, and the successors to Plan B, namely Plans E and F, will be examined. A description of events related to the termination of the Interim Air Force and establishment of the Regular and Auxiliary RCAF are provided. Details of the emerging structure for air force planning will also be reviewed and circumstances surrounding the growth of the Canadian aviation industry will be described. Finally, this chapter will trace the changing threat environment and assess how the RCAF responded. 
Inter-Service Planning Group

In preparation for the defence budgets covering the fiscal year 1947-1948, ${ }^{1}$

Cabinet had requested that the three services provide funding estimates for consideration. Upon receipt of them, Cabinet found the three submissions to be disjointed and done in isolation without consideration for the other services. In November 1946, the Chiefs of Staff were directed to develop, within two weeks, a balanced, joint Master Plan for the services with due regard for all relevant factors. ${ }^{2}$ Another consequence of the lack of coordination between the three service budget submissions was the decision by Prime Minister Mackenzie King and his Cabinet in December 1946 to consolidate the services into a single Department of National Defence under one minister, Brooke Claxton. King did not think that the outgoing Minister of National Defence for Air, Colin Gibson, had done a good job in constraining RCAF demands, ${ }^{3}$ especially since as early as October 1946 the government had foreseen the requirement to cut back on defence expenditures due to the lagging Canadian economy and the cost of social programmes supported by the government. ${ }^{4}$ In fact, such was the Prime Minister's concern about the level of defence expenditures that he decided to personally preside over the Cabinet Defence Committee, ${ }^{5}$ the meetings of which he had attended only periodically. ${ }^{6}$

\footnotetext{
${ }^{1}$ The government's financial planning cycle goes from the $1^{\text {st }}$ of April of one year until March 31st of the following year. Accordingly, in order to be prepared for an upcoming fiscal year, government departments, including National Defence, typically would be asked for estimates beginning in the Fall of the preceding year.

${ }^{2}$ DND, DHH 193.009 (D53), Box 1, 1946 Papers and Meetings, Chiefs of Staff Committee, Minutes of the $371^{\text {st }}$ Meeting, 25 November 1946, p. 4.

${ }_{3}^{3}$ LAC, W.L. Mackenzie King Papers, MG 26 J13, Box 118, Diary, Thursday, 12 December 1946, pp. 1116-1118.

${ }^{4}$ LAC, W.L. Mackenzie King Papers, MG 26 J13, Box 118, Diary, Wednesday, 16 October 1946, p. 929.

${ }^{5}$ LAC, W.L. Mackenzie King Papers, MG 26 J13, Box 119, Diary, Tuesday, 14 January 1947, p. 43.

${ }^{6}$ A review of Cabinet Defence Committee Meeting Minutes shows that Mackenzie King did not attend any meetings from August - December 1945 and tended to show up in 1946 only when significant issues were
} 
To bring service demands together and develop the requested joint Master Plan, the Inter-Service Planning Group was formed, with representatives from each of the Services, and it began a series of meetings. These meetings commenced in December 1946 at the same time as the release of the first postwar threat appreciation, the contents of which are described in the previous chapter; this appreciation included a significant focus on the potential for Soviet aggression on North America from the air. ${ }^{7}$ Although the government was calling for cutbacks, the air force representative to the Planning Group seized on the threat appreciation's recommendation for a larger RCAF capable of intercepting a Soviet air attack. Air Commodore C.R. Dunlap informed the Planning Group that:

It is my belief that a Master Plan for the Armed Services of Canada is an urgent necessity at the present time. Furthermore, I am strongly of the opinion that giving due regard to the World Strategic situation and the current U.S.-Canada planning for the defence of the North American Continent that it is inevitable that the R.C.A.F. must assume the major role certainly during the years of peace. Any planning which takes place at the present time should therefore reflect the new circumstances which have arisen since the original conception of the Royal Canadian Air Force Post War Plan.

$\mathrm{We}$, at the present moment, are required to produce at short notice a plan to support the estimates for the fiscal year 1947-48. We have been directed by Cabinet to meet around a common table and make this an integrated plan based on an appreciation of the situation as we now visualize it. This being the case, I find it impossible therefore to use the existing Post War Plans as our foundation for planning - to me the division of manpower as between the three services is no longer in the right proportion and I consider that I would be guilty of falsely represinting [sic] the conditions as they exist today I were to subscribe to any joint plan prepared and submitted on this basis.

being discussed, such as the Basic Security Plan. In 1947, his attendance was just as irregular. For instance, between February and August, he missed eight consecutive meetings.

${ }^{7}$ LAC, RG 24, Vol 6174, file HQ 19-7-79, Vol 1, Joint Appreciation and Plan: Canadian Armed Services, Parts I, II, II and Appendices A, B1, B2, B3, December 1946, p. 3. 
I have come to the conference table in a spirit of co-operation and with a deep realization of the problems of the Army and the Navy and the magnitude of their various undertakings in relation to the training of Regular and Reserve Formations and their heavy responsibilities in relation to mobilization stores - these requirements consume large portions of manpower but nevertheless the same also applies to the R.C.A.F. and with the new commitments faced by the latter service, it is now time in my opinion for a re-adjustment of the allocation of manpower with a substantial increase in favour of the Royal Canadian Air Force. ${ }^{8}$

This lengthy quotation is noteworthy for a number of reasons. In the first place, it provides a clear indication of the RCAF's focus on its own interests, even at the expense of the other services. A month before this submission by Dunlap, during a Cabinet Defence Committee meeting in November 1946, Leckie had argued against the magnitude of the air defensive measures required under the Basic Security Plan while Foulkes supported them. Leckie and Foulkes later switched their opinions to align with the interests of their services and advocacy of organizational self-interests became the norm between the postwar army and air force. Secondly, as demonstrated during the protracted dealings with the government about the size of the postwar air force, Dunlap's comments show that the RCAF was more than willing to challenge any government decisions contradicting the organizational preferences of the air force. Thirdly, Dunlap demonstrated a strong and forceful character, traits that the RCAF leadership required to change the fortunes of the air force.

Further details on the reasoning behind Dunlap's letter to the Inter-Service Planning Group were provided in an aide-memoire. It conceded that each service contributed to the defence of Canada, but argued that the nature of the threat meant that

\footnotetext{
${ }^{8}$ LAC, RG 24, Vol 6174, file HQ 19-7-79, Vol 1, Letter from Air Commodore C.R. Dunlap to Chairman, Interservice Planning Group, dated 1 December 1946.
} 
priority should be given to the air force. While it acknowledged that recent threat assessments indicated that Soviet air attacks were likely to be of a harassing nature for the next number of years, the RCAF believed that the destructive capability of atomic bombs, which the Soviet Union was likely to have by 1952 , showed that the seriousness of the air threat to North America would not diminished. ${ }^{9}$ This aide-memoire went on to note that senior army staff believed that the "day of the strategic bomber is near an end and that its place will be taken by pilotless [sic] aircraft, guided missles [sic] and rockets, their thesis being based primarily on the matter of the tremendous national effort required to produce great fleets of strategic bombers and also on the attrition of such aircraft in the face of modern defensive weapons. Although this is an argument which does not conern [sic] the RCAF as presently constituted, it involves a false doctrine and one which we should be prepared to stamp out whenever the question arises." ${ }^{\prime 10}$ In opposition to the army's conviction, the air force believed that research and development would lead to Soviet strategic bombers with increased speed, armament and sighting aids and radar jamming. The RCAF expected guided missile attacks only after new defensive measures countering such bomber-related developments were fielded, making such bomber attacks too costly. ${ }^{11}$ In the meanwhile, interceptors and the means for the radar detection of attacking aircraft would be required. The difference of opinion between the army and the air force concerning the nature of the threat, which had implications for the composition and relative size of military forces, would continue for many years, culminating during the 1950s in public attacks by retired army officers on Canadian politicians and the RCAF.

\footnotetext{
${ }^{9}$ Ibid., attached undated, untitled aide memoire, pp. 2-7.

${ }^{10}$ Ibid., p. 8.
} 
Dunlap was able to convince the Inter-Service Planning Group that resources should be reallocated immediately to allow an increase in the RCAF in the form of a transport squadron and a fighter wing composed of two squadrons, with additional increases to be considered following study over the next few months in conjunction with the United States. Moreover, the Planning Group recommended that an internal review be conducted with a view of finding economies by combining select operations and administration being conducted by the three services. These economies were intended to identify resources that could be reassigned to combatant roles, particularly for the RCAF. ${ }^{12}$ Surprisingly, these recommendations encountered opposition from the Chief of the Air Staff himself, who "did not consider the provision of a fighting wing during the next fiscal year to be a matter of top priority." He placed higher importance on surveying and selecting sites for an air defence system, including radar stations, interceptor bases and anti-aircraft installations. Leckie believed that, with the exception of the transport squadron, augmentation to the RCAF should be deferred until more complete planning was completed, although a preliminary indication of future intentions should be provided to the government. The Chiefs of Staff Committee concurred with this plan, agreeing that an eventual increase of around 50 percent was in line for the RCAF sometime in the future. $^{13}$

This difference of opinion between Leckie and Dunlap was symbolic of a wider issue. Some within the RCAF had noted that air force planning was ad hoc, inadequate and slow. Group Captain Robert Ripley brought to the attention of senior leadership that,

\footnotetext{
${ }^{11}$ Ibid.

${ }^{12}$ LAC, RG 24, Vol 6174, file HQ 19-7-79, Vol 1, Extract from Minutes of the $372^{\text {nd }}$ Meeting of Chiefs of Staff Committee Held at 1500 hours, Sunday, 1 December, 1946.
} 
after almost a year, the RCAF had produced only a general Postwar Plan, which failed to consider United Nations commitments or details on North American defence with the United States. Other issues, such as mobilization, equipment acquisition, future aircraft specifications and emergency preparedness, were being handled in a haphazard manner. He argued that "[a]t the present time too many people are guessing and if it continues the RCAF is not going to be efficient and what money we do get is not going to be spent economically." The solution to this, in Ripley's opinion, was the creation of a fulltime planning staff under the Chief of the Air Staff. ${ }^{14}$

These observations by Ripley go to the heart of the RCAF's problems with planning up until this time. The Post War Organization Committee in 1944 had recommended the creation of a planning branch, ${ }^{15}$ but this failed to materialize, along with the rest of that Committee's recommendations. Plan B that followed identified numerous roles for planning for the air force, ${ }^{16}$ but gave no indication of how this work would be done. As attested by Ripley's comments, the problem was that the RCAF devoted inadequate resources to the planning function. The low manning level of the air force contributed to this, as demonstrated by some units operating at 30 percent strength. Yet the future of the air force depended upon the ability to identify and articulate requirements in an effective manner. Planning required the participation of those with strategic vision, capable of foreseeing air force requirements and working out solutions. Such planners also needed appropriate access to senior RCAF leadership, so that air force

${ }^{13}$ DND, DHH, 193.009 (D53), Box 1, 1946 Papers and Meetings, Chiefs of Staff Committee, Minutes of the $373^{\text {rd }}$ Meeting, 9 December 1946.

${ }^{14}$ LAC, RG 24, Vol 5225, file S-19-7-71, Vol 8, Memorandum S19-7-17 (DSM), entitled "RCAF Planning", from Group Captain Robt C. Ripley, DSM, to AMP, dated 15 July 1946.

${ }^{15}$ LAC, RG 24, Vol 5226, file S-19-7-71A, Vol 1, Post War Organization Committee Minutes of Meeting No. 18 held on the $7^{\text {th }}$ September, 1944, at 1930 hours, Annex B. 
plans reflected the intent of the Chief of the Air Staff. In time, Ripley's observations on the problems with air force planning were addressed.

The Inter-Service Planning Group provides an interesting case study. For the first time after the war, the three services were brought together to develop a joint budget submission to the government. This caused each of the services to consider the overall demands upon the government and not to focus exclusively upon their own requirements. Dunlap was a strong representative for the air force and his ability to convince the other services to support additional resources for the air force, in the form of a transport squadron and a fighter wing, by accepting reductions in their own forces showed that the role of the RCAF was becoming more important to Canada.

\section{Development of Plan E}

In January 1947, the government began by reconstituting its Cabinet Defence Committee, which included the Prime Minister as Chair, the Minister of National Defence as Vice-Chair, and members from the Department of External Affairs, the Minister of Finance and a third department, plus a secretary from the Privy Council Office. Its stated mandate was to "undertake careful examination of major defence questions ${ }^{\text {,17 }}$, and Mackenzie King, who was deeply concerned about the defence costs, sought to keep them under control through his personal participation. ${ }^{18}$ Regardless of his motivation, the composition of this committee resulted in defence-related issues being

\footnotetext{
${ }^{16}$ DND, DHH, 181.004 (D 44), Plan B - Post War Plan for the Royal Canadian Air Force, April 1946, p. 34.

${ }^{17}$ LAC, RG 24, Vol 5185, file S-15-9-56, Vol 3, Letter with no file number dated 7 January 1946, from Colonel J.L. Cameron to CAS, CGS and CNS, entitled "Cabinet Defence Committee Reconstitution".

${ }^{18}$ LAC, W.L. Mackenzie King Papers, MG 26 J13, Box 119, Tuesday, 14 January 1947, p. 43.
} 
considered at the highest levels of government, ensuring at least the opportunity to introduce defence issues to governmental decision-makers.

Soon thereafter, the renewed drive for defence austerity was felt by each of the services. Early in 1947, in response to governmental direction, the military services developed new plans based on reduced expenditures. For the RCAF, which was directed to come up with over \$27 million in savings from the level of the previous year's defence budget (from $\$ 89$ million under Plan B to $\$ 61.5$ million), a decision was made to cap the number of Regular Force personnel "somewhat in excess to" $12,000,{ }^{19}$ well below the approved level of 16,100 . The air force also chose to reduce the intended number of Regular Force squadrons to one bomber reconnaissance, two transport and one photographic survey squadrons plus a mobile tactical wing (consisting of a fighter bomber, a fighter reconnaissance, and an air observation squadron plus an air transport flight) and an interceptor-fighter wing (comprising two air interceptor squadrons) from the previously identified ten operational squadrons (three bomber reconnaissance, three transport, and one each for photographic, fighter reconnaissance, fighter bomber and air observation) and eight composite flights. ${ }^{20}$ Plans for the Auxiliary went from 19 squadrons to eight fighter squadrons and two tactical bomber squadrons. ${ }^{21}$ Toronto and St. Hubert were each allotted two of these squadrons, with the remainder going to Hamilton, London, Winnipeg, Saskatoon, Edmonton and Vancouver. ${ }^{22}$ The number of aircraft per squadron also dropped from the normal 18 and the 12 intended under Plan B

\footnotetext{
${ }^{19}$ DND, DHH 181.004 (D45), RCAF Plan “E” 1948-49, p.2.

${ }^{20}$ Ibid., Appendix A, Sheet 5 .

${ }^{21}$ Ibid., p. 1.

${ }^{22}$ Ibid., Appendix C, Part X.
} 
to eight under Plan E. ${ }^{23}$ The number of geographic formation headquarters was reduced from five to two, leaving only Northwest Air Command Headquarters located in Edmonton and Central Air Command in Trenton. Figure 4 shows the areas of responsibilities for these remaining Commands.

\section{Figure 4: Plan E Geographic Command Structure ${ }^{24}$}

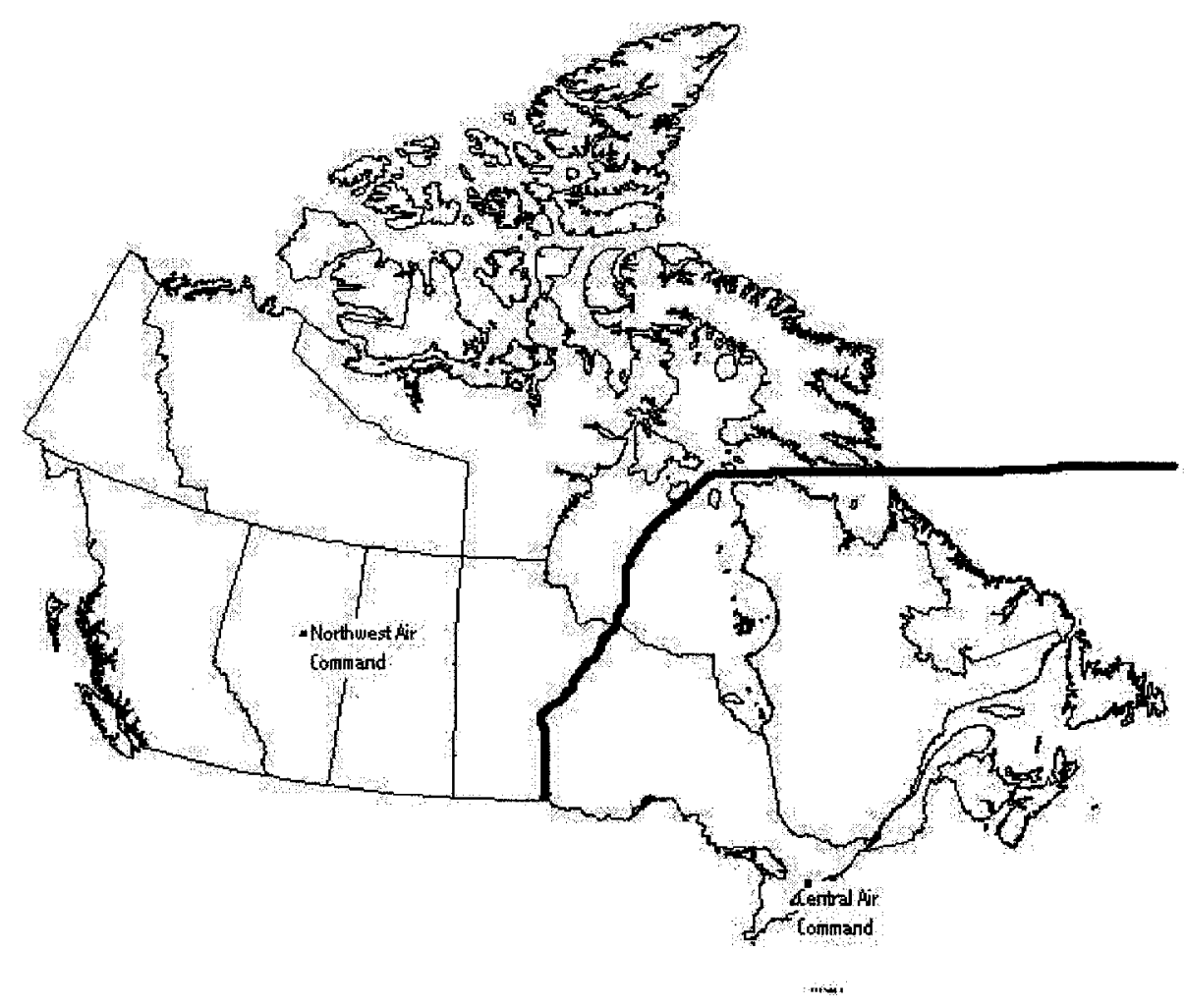

Plan B had identified the intention to rollout squadrons and capabilities between February and October 1947 . More realistically under the new circumstances, Plan E

${ }^{23}$ Ibid., p. 2.

${ }^{24}$ Note that the geographic division between the two geographic commands at the Ontario-Manitoba border was not explicitly spelt out in Plan E, but the identification of command relationships for the various bases indicated this to be the case. 
caused this to be delayed until 1948 and $1949 .{ }^{25}$ During this period, the RCAF planned to introduce their first jet propulsion aircraft, the De Havilland Vampire, in small numbers. Seven were allocated for the flying school and four for the armament schools in Trenton. Another four Vampires were sent to each of St. Hubert, Toronto, Winnipeg and Vancouver for use by the Auxiliary squadrons. Initially at least, none of the Vampires was allocated to the Regular RCAF. In addition, a variety of wartime vintage Ansons, Austers, Cansos, Dakotas Expeditors, Gooses, Harvards, Liberators, Mitchells, Mustangs and North Stars were despatched to various Regular and Auxiliary RCAF locations across the country. ${ }^{26}$ The majority of these could serve no military role beyond providing basic flight training or helping with the transportation role.

Plan E was submitted to Cabinet on 14 January 1947. Minister Claxton noted that this plan, as well as those for the army and navy, had been prepared with the purpose of achieving the maximum reductions possible. ${ }^{27} \mathrm{He}$ cushioned the impact of the cuts by suggesting that the plans be viewed as partial implementation of previously announced policies rather than permanent new programmes. This provided hope that the services would obtain better funding once economic conditions improved. He advocated that the reduction in manpower, which represented a cut from 16,100 to around 12,000 for the air force, be treated as a temporary restriction during a transitional period. Mackenzie King thought otherwise and expressed the opinion that the higher staffing level under Plan B

\footnotetext{
${ }^{25}$ DND, DHH 181.004 (D45), RCAF Plan "E" 1948-49, Appendix Q.

${ }^{26}$ Ibid.

${ }^{27}$ LAC, RG 2, Vol 2748, Vol 2, Minutes of the Cabinet Defence Committee held in the Privy Council Chamber on Thursday, January $14^{\text {th }}, 1947$, para 4, p. 2.
} 
was given only for planning purposes; these reductions were to be treated as government policy. Plan E was approved by the government. ${ }^{28}$

The RCAF was in a poor state as a result of this new plan. It had no effective fighting capability and a range of initiatives had to be delayed or terminated. In the absence of operational aircraft or squadrons capable of performing the role, Canada was without any means of providing air defence against the threat identified in the various appreciations. The air force also stopped recruiting immediately. ${ }^{29}$ In view of the problems encountered in staffing, this was likely a mixed blessing. Although new personnel would not be inducted during this period, at least the air force could examine its situation and attempt to improve its performance in this area through new policies initiatives and improvement to conditions. Another consideration was that the RCAF had limited ability to train recruits at this time, so the respite given by Plan E provided the opportunity to correct this shortfall.

The net effect of the cutbacks necessitated by this government-directed restraint was that the air force "could not be regarded as providing more than a framework upon which to build in time of emergency." ${ }^{30}$ This was a further reduction from Plan B, which identified the air force's role as that of providing "a well balanced nucleus of highly proficient personnel, which is capable of rapid, efficient expansion in the event of an emergency" ${ }^{31}$ With Plan E, the RCAF no longer saw itself as capable of quickly or effectively responding to a crisis. The initial postwar intention of fielding "an air force in

\footnotetext{
${ }^{28}$ Ibid., paras 7-16, pp. 3-5.

${ }^{29}$ Ibid., para 7, p. 4.

${ }^{30}$ LAC, RG 24, Vol 5226, file S-19-7-71D, memorandum S.19-7-71, dated 14 January 1947. For a complete copy of Plan E, see DND, DHH 181.004 (D45). Note that Plans A-C inclusive were the schemes developed after the end of World War II, with Scheme B, Post War Plan for the Royal Canadian Air Force, becoming known as Plan B. While no copy of it has been located, Plan D was likely the plan under development as the successor to Plan B that was derailed by the government directed reductions.
} 
strength and readiness to uphold national policies and interests and to guard Canada from air attack"32 was now a distant objective. Putting a positive interpretation on this turn of events, Leckie's staff asserted that these cuts were made at a time that would not imperil the developing joint defence plans with the United States. This was because the Basic Security Plan was not advanced enough to determine personnel and equipment requirements. $^{33}$

A shortfall of Plan E, necessitated by the forced economic restraint, was its failure to address the state of its inventory of aircraft. Although initial plans were made leading to the eventual development of the CF-100 and a number of Vampires were coming into service, a compelling shortcoming of the postwar air force was the absence of an overall plan for the phased retirement of wartime vintage aircraft and the adoption of modern technology. There was no consistent vision on how to move the force from one state of technology (propeller aircraft) to the next (jet propulsion aircraft). As a military entity, by the end of 1947 , the air force was close to impotent, stuck using largely out of date equipment with extremely limited combat capability. This state of affairs was acknowledged by the Chiefs of Staff Committee in March, when it noted that because of recent reductions, "certain long-term weaknesses would result and would affect capability of eventual implementation of the Basic Security Plan since there had been a

\footnotetext{
${ }^{31}$ DND, DHH 181.004 (D44), Post War Plan for the Royal Canadian Air Force, April 1946, p. 1.

${ }^{32}$ LAC, RG 24, Vol 5226, file S-19-7-71A, Vol 1, Post War Organization Committee Minutes of Meeting No. 18 held on the $7^{\text {th }}$ September, 1944, at 1930 hours, Appendix B, p. 2.

${ }^{33}$ LAC, RG 24, Vol 6174, file HQ 19-7-79, Vol 1, memorandum TS 15-24-10 (CAS) TS 19-7-79, from Secretary to Chief of the Air Staff to AMAP, dated 13 February 1947.
} 
proportionately high percentage of reduction in the operational capabilities of the Services. ${ }^{.34}$

Moreover, even the preliminary steps taken towards the introduction of jet propulsion technology were not going as planned. Although negotiations in early 1946 had led to the expectation that 183 Vampires would be provided by the United Kingdom, delays in production and cost increases resulted in a reduction in the number of aircraft to be provided. The new commitment was to deliver just 85 of these jets and few spare parts and engines. This number was sufficient to equip only a limited number of squadrons, which brought into question the RCAF's ability to meet even its meagre postwar plans. While the RCAF could have decided to purchase more Vampires, it was realized that this aircraft was only an introduction to the new technology and unlikely to satisfy long term operational requirements. ${ }^{35}$ Therefore, the RCAF had to consider cutting its losses with the Vampire and examine the possibility of finding a replacement for this newly acquired asset; the results of a study into this issue are included in the next chapter.

On 27 March 1947, another intelligence appreciation was released. Produced jointly by the army, navy and air force intelligence organizations, as well as representatives from Defence Research's Directorate of Scientific Intelligence, the Royal Canadian Mounted Police and the Department of External Affairs, this report once again assessed the prospects of conflict with the Soviet Union and what form conflict would take. While identifying the Soviet Union as the only likely enemy in the foreseeable

\footnotetext{
${ }^{34}$ DND, DHH 193.009 (D 53), Box 2, Papers and Meetings, Chiefs of Staff Committee, Vol 64, March 1947, Extract from Minutes of the $383^{\text {rd }}$ Meeting of the Chiefs of Staff Committee, Held on 17 March 1947, para 4.
} 
future, this assessment also indicated that it was "considered unlikely that a war between the USSR and the USA, involving Canada, would be embarked on by the Soviet Union, either deliberately or as a result of a success of accidents, with the next ten years." ${ }^{.36}$ This statement was followed with the caveat that the "possibility of the USA provoking such a war is disregarded for purposes of this appreciation. ${ }^{, 37}$

The main reason that the USSR probably would not initiate war in this ten-year period was its economic disadvantage in comparison to the United States, which had significantly more industrial production capability. The Joint Intelligence Committee foresaw war as being much more likely to occur between 10-25 years in the future, with the Soviet Union using the intervening period to consolidate gains in Europe, develop and use weapons of mass destruction, and achieve closer economic parity with the United States. ${ }^{38}$ Acknowledging that achievement of this state of affairs could lead to conditions favourable for the Soviet Union to pursue war, the Committee believed that so long as "the Western democracies were firm and united, and if they pursued strong but fairminded policies, the Soviet government might be disposed to postpone indefinitely the accomplishments of their ultimate aims. ${ }^{.39}$ The means of accomplishing such a firm and united front would come about in two years later in the form of the North Atlantic Alliance.

\footnotetext{
${ }^{35}$ DND, DHH, Raymont Papers, 73/1223, File 1820, Minutes of the $67^{\text {th }}$ Meeting of the Air Members, held at 1500 hours, Monday, 14 February 1949, p. 4.

${ }^{36}$ DND, DHH 193.009 (D 53), Box 2, Papers and Meetings, Chiefs of Staff Committee, Vol 66, May 1947, J.I.C. 1 (Final), report entitled "Joint Intelligence Committee - Strategic Appreciation", dated 15 March 1947, p. 1, attached to memorandum JIC 1-8-1, entitled "Strategic Appreciation", dated 27 Mar 47, from W.W. Bean, Group Captain, Secretary, Chiefs of Staff Committee, to CAS, CGS, CNS and DGDR. ${ }^{37}$ Ibid.

${ }^{38} \mathrm{Ibid}$.

${ }^{39}$ Ibid.
} 
In assessing the geographic elements associated with the threat, the appreciation noted that the shortest distance from the Soviet industrial heartland to North America was across the polar cap and along the Canadian northeast. This was the direction from which the greatest air threat was expected. While attack along the Pacific coast was possible, the limitations of the Trans-Siberian railway meant that no major, sustained offensive operation could be mounted by the Soviets. Similarly, while an attack could be mounted across the Atlantic, such an approach would first require the defeat and occupation of Europe. The threat of this happening likely would cause the United States to become involved long before a Soviet victory in Europe could be achieved. Therefore, any attack on North America would depend upon Soviet industrial capacity increasing, leading to greater air and sea transport capabilities. ${ }^{40}$

The Joint Intelligence Committee anticipated that the USSR would not have atomic weapons before 1950, would take until 1956 to achieve a stockpile of between 4060 weapons and could achieve sufficient number of bombs to launch a full scale attack on North America by 1961. While it was anticipated that any atomic attack on Canada would only follow destruction of American industrial centres, it was believed that if more than 20 atomic bombs were used, one or two would have Canadian targets. ${ }^{41}$ Canada could not disregard the threat posed by atomic weapons, even if not the likely primary target.

During the intervening years between 1947 and the development of a Soviet atomic capability, the Joint Intelligence Committee indicated that chemical and biological weapons were the primary threat to North America, especially if war occurred sometime

\footnotetext{
${ }^{40} \mathrm{Ibid}$.

${ }^{41}$ Ibid., p. 3.
} 
between 1949 and 1952. Moreover, when examining the state of Soviet guided missile technology, the Committee thought that, despite having control of German scientists with experience in the field from the Second World War, it "was highly improbable [the USSR] will possess guided missiles with which she can bombard North America from presently occupied land bases in less than 10 years' time." Sea- or air-launched missiles remained a threat within 200 miles. $^{42}$

An assessment of the state of the air threat from the USSR indicated that no substantial capability existed at that time. The Joint Intelligence Committee estimated that the Soviet Union could launch a conventional attack against Alaska and the northwest edge of Canadian territory, or perhaps near the Manitoba-Ontario border on a one-way mission. In the event that a high national priority was given in the USSR to building a long-range strategic bomber similar to the B-29 (a long range, strategic bomber used primarily by the United Stated during World War II until the early 1960s, with a combat radius of 3250 miles, maximum speed of 310 knots per hour and a service ceiling of 33,600 feet), an arc from Los Angeles on the Pacific coast to Ontario would be vulnerable to two-way attack within five years. The intelligence threat appreciation concluded that within ten years, the Soviet Union would be capable of developing and mass producing a next generation long-range bomber in sufficient numbers to be able to subject all of North America to a two-way attack. ${ }^{43}$

This period saw two completely divergent forces at play. The government had to reduce defence spending, which was appropriate because of the domestic pressures

\footnotetext{
${ }^{42}$ Ibid. It is noteworthy that the Joint Intelligence Committee's estimate, in 1947, of it taking ten years for the USSR to develop the capacity to attack North America with missiles was prescient. The 4 October 1957 launch of the first Sputnik announced the arrival of the age of intercontinental ballistic missiles. See http://history.nasa.gov/sputnik/
} 
experienced at the time. This resulted in an impotent RCAF with limited operational capabilities. Yet, at the same time, the Canadian and American intelligence community was identifying an increasingly serious and potent threat to national security. The Soviet Union was considered more and more as capable and willing to attack North America. If this threat was to be addressed, the government was going to have to change its direction.

\section{Countering the Threat}

This threat information can be examined to establish its implications for RCAF planning activities in the future. According to the best information of the time, the direct threat to North America posed by the Soviet Union in 1947 was minimal, but the expectation clearly was that this threat would increase over time and that it would largely come from the air. In the relatively short term, if given priority by the Soviet Union, military planners anticipated that the initial bomber threat would consist of an aircraft capable of reaching few significant North American targets, flying to a height of around 34,000 feet and achieving a top speed of around 310 knots. After about a decade, aircraft able to go further, higher and faster were expected to be developed and fielded. Such increased capability resulted in more North Americans targets becoming vulnerable as time passed. While there was no perceived immediate atomic threat, by the mid-1950s some level of threat was expected, which would increase and become more prominent by the early 1960s. From this, the RCAF could derive specifications for fighter-interceptors intended to counter the future bomber threat. Since it took time to develop and build new equipment, this implied that it was time for the air force to start thinking about the next generation of aircraft.

\footnotetext{
${ }^{43}$ Ibid., p. 4.
} 
The various threat assessments indicated that it was time for the RCAF to get beyond the planning stage for an air defence system and proceed with building it. Elements of such a system included radar stations across the Canadian north, centres to coordinate the intersection of the intruding bombers and the intercepting fighters, and airfields at strategic locations equipped with sufficient fighters to deal with an attacking force. The problem for the RCAF was that such an undertaking necessitated a massive financial commitment on the behalf of the government. Moreover, given the time needed to build such a system, the overall costs and the complexity associated with building such a large, integrated system, the RCAF would have to take a phased approach. These phases had to be coordinated to ensure that the completed system was in place in time to counter the expected threat. This was a significant challenge for the RCAF, the accomplishment of which would be a central focus for the air force for many years to come.

One of the cumulative effects of these Cold War threat assessments can be seen around mid-1948, at which time steps were taken to develop a process for identifying the operational requirements for future military aircraft. In an effort to establish a balanced, multi-purpose force, capable of fulfilling a wide range of air force roles, the RCAF articulated the capabilities of a range of aircraft, from a day interceptor to a night fighter to long and medium range transport aircraft. As part of this process, caution was expressed about the necessity for these requirements to be "kept fully up to date, apace with technical advances and changing requirements." ${ }^{.44}$ An example of these requirements included Operational Requirement No. OR/1 for a day interceptor, which 
was intended to destroy enemy high-speed, high-altitude bombers during daytime. In view of the vastness of Canadian territory, such an aircraft needed to have the ability to operate across an area of 400 nautical miles, with a speed of 500 knots up to a ceiling of at least 50,000 feet. This aircraft would also require good manoeuvrability and be strong enough to safely take up to $8 \mathrm{Gs}^{45}$ Armament would consist of two $30 \mathrm{~mm}$ cannons or four $20 \mathrm{~mm}$ cannons, capable of firing continuously for 15 seconds. ${ }^{46}$

A related specification was Operational Requirement No. OR/4 for an all-weather interceptor. It called for an airplane capable of 478 knots, a 41,000-foot ceiling, and a range of 2200 miles at cruising speed. ${ }^{47}$ The specifications for a day interceptor and allweather interceptor would soon provide the basis for significant expansion of the RCAF aircraft inventory and, so long as they were built in sufficient numbers, would supply the means to respond effectively to the bomber threat. These aircraft would comprise the bulk of Canada's Cold War air force.

Operational requirements also were identified for a light bomber and a long-range bomber. The light bomber was intended to operate in support of land forces and be able to carry a bomb load of 10,000 pounds with a range of 800 nautical miles. ${ }^{48}$ This requirement was certainly in keeping with the air force's responsibility to provide close air support to the army during land operations. On the other hand, the specification for

\footnotetext{
${ }^{44}$ LAC, RG 24, Vol 5394, file HQS 60-1-76, memorandum S-60-1-76 (DOR), entitled "Operational Requirements - Future Aircraft", dated 23 June 1948, from W.A. Orr, A/C, Acting AMAP to AMOT, Minute 2 by C.R. Slemon, AVM, AMOT, dated 14 July 1948.

${ }^{45} \mathrm{~A} \mathrm{G}$ is a descriptive measure of the forces on a body from acceleration and deceleration, and is expressed in multiples of gravity, or G. See http://cssel.eng.ohio-state.edu/voshell/gforce.pdf, p. 2/28. The higher the $\mathrm{G}$, the greater the pressure put on an aircraft and its occupants.

${ }^{46}$ LAC, RG 24, Vol 5394, file HQS 60-1-76, memorandum S-60-1-76 (DOR), entitled "Operational Requirements - Future Aircraft", dated 23 June 1948, from W.A. Orr, A/C, Acting AMAP to AMOT. ${ }^{47}$ Ibid.

${ }^{48}$ LAC, RG 24, Vol 5394, file HQS 60-1-76, memorandum S-60-1-76 (DOR), entitled "Operational Requirements Nos 7 and 8", dated 29 July 1948, from A.L. Morfee, AVM, AMAP to AMOT.
} 
the heavy bomber described an aircraft capable of carrying the same bomb load as the light bomber but with three times the range (2400 nautical miles), able to manoeuvre at high speed and high altitude with defensive armament. ${ }^{49}$ This specification reflects backtracking from the Plan B decision to avoid the heavy bombing role, for which there is no indication of senior political or military leadership support.

When looking at the full range of operational specifications, it is evident that they were an internal planning tool, which were used to articulate options, or even intentions, for the future air force, to be called upon as circumstances and requirements dictated. The mere presence of an operational specification does not necessarily reflect an intention to build an aircraft of that type. But these specifications deserve recognition as a concrete example of the RCAF planning for the future, which was an area that the air force required to get better at.

\section{An Enhanced Planning Capability for the RCAF}

The requirement for a formal process to develop air force plans, as mentioned by Ripley ${ }^{50}$ was partially resolved with the May 1947 creation of the Current Plans and Estimates Committee. Organizationally aligned under a new senior officer, the Air Member for Air Plans, this committee was made responsible for producing "current plans for the RCAF, and ... [producing] yearly estimates covering the activities of the RCAF for each fiscal year". ${ }^{51}$ It was headed by the Deputy, Air Member for Air

\footnotetext{
${ }^{49}$ LAC, RG 24, Vol 5394, file HQS 60-1-76, memorandum S-60-1-76 (DOR), entitled "Operational Requirements - Future Aircraft", dated 30 August 1948, from C.R. Dunlap, A/C, Acting AMAP to AMOT. ${ }^{50}$ LAC, RG 24, Vol 5225, file S-19-7-71, Vol 8, Memorandum S19-7-17 (DSM), entitled "RCAF Planning", from Group Captain Robt C. Ripley, DSM, to AMP, dated 15 July 1946.

${ }^{51}$ LAC, RG 24, Vol 5193, file 15-9-124, part 1, Organization Order CTE 179, Current Plans and Estimates Committee, file number 175-P-28 (DOE), dated 6 May 1947.
} 
Plans/Operations, and included representatives from the Directorate of Organization and Establishment, Directorate of Operational Requirements, Air Plans 3 and a representative from the office of the Deputy Minister. This committee quickly became focused on how to go about implementing Plan E, but expressed concern about whether to base such planning on Plan B manning levels $(16,100)$, the manning levels expected in the event of mobilization (an unspecified number greater than 16,100), or the Plan E approved level of 12,100 . It resolved to all but avoid the issue by deciding to develop plans and estimates to suit all three contingencies. ${ }^{52}$ This decision showed that the air force was beginning to take a more comprehensive, professional approach to planning.

The subsequent development by the Current Plans and Estimates Committee of implementation priorities for the air force provides good insight into what was considered important to the RCAF. Priority A was the development of search and rescue flights on the east and west coasts, research and development into Basic Security Plan-related radar, and the creation of flight and officer training establishments and maintenance units. This set of priorities was designed to address a number of RCAF operational shortcomings, including the ability to fulfil a government-mandated role (search and rescue) and improvements to the state of the science of radar detection, in order to adequately cover the full expanse of Canadian territory. Improvements in these areas would also lead to the development of a training system capable of satisfying the pilot requirements of the $\mathrm{RCAF}$ and the creation of the maintenance facilities needed to keep aircraft flying.

The Current Plans and Estimates Committee assigned Priority B to the creation of the Joint Air School in Rivers, Manitoba, trade schools and technical depots, research

\footnotetext{
${ }^{52}$ LAC, RG 24, Vol 5193, file 15-9-124, part 1,Minutes of the Second Meeting of the Current Plans and Estimates Committee Held in Room 2571, "A" Building at 1430 Hours, $12^{\text {th }}$ May 1947, file number S15-9-
} 
units, and transportation flights. This set of priorities facilitated air force cooperation with and support to the Canadian Army and the Royal Canadian Navy and the need to train the personnel required to staff the maintenance facilities being created under Priority A. It also sponsored expansion of the research and development capacity established under Priority A, so air force capabilities could be improved in areas other than just radar. Priority B also led to the establishment of an initial capability to move personnel and materiel across the country. Priority $\mathrm{C}$ was given to establishing additional transportation flights and technical depots, and aviation medicine research. These initiatives facilitated the creation of a more robust transport and maintenance system, as well as committed resources to medical research into personnel issues related to flying. The final priority was allotted to the establishment of Auxiliary Squadrons and a tactical wing to support the Joint Air School. ${ }^{53}$ This priority assisted with the rollout of the Auxiliary RCAF in its various functions and provided the means for the air force to work with the army and navy at the Joint Air School.

Overall, these priorities indicate that Basic Security Plan and training requirements received good support by the RCAF, as did research and development activities. Flight-related tasks tended to be in the area of a government-mandated search and rescue capability and the transportation role, with the provision of flight support to the Joint Air School and the Auxiliary Squadrons ranking low in the committee's deliberations. However, since the provision of operational aircraft to the Regular RCAF

124 (DOE), dated 13 May 1947, pp. 2-3.

${ }^{53}$ LAC, RG 24, Vol 5193, file 15-9-124, part 1,Minutes of the Third Meeting of the Current Plans and Estimates Committee Held in Room 2571, "A" Building at 1445 Hours, $15^{\text {th }}$ May 1947, file number S15-9124 (DOE), dated 20 May 1947. 
did not even appear on the RCAF's priority list at this time, it would be unfair to suggest that the air force was discriminating against the other services or the Auxiliary RCAF.

Planning fulfils a range of functions, from forecasting future requirements and developing means of accomplishing identified tasks to determining how many personnel were needed and how they may be employed. Another aspect of planning relates to assessing how resources could be best utilized or even what was no longer required by the RCAF. A demonstration of this was provided in an August meeting of the Current Plans and Estimates Committee, when discussion indicated that manpower shortages stopped the air force from making use of some aircraft it had on inventory. It was further noted that some aircraft were unsuitable for the training role. This led to the decision to retire Dakotas, Mitchells and Mustangs from the flight training system. ${ }^{54}$ It was through actions such as this that the air force phased out older equipment, which had to take place if the air force was ever to get to the next level of technological development.

While working to implement Plan E, senior RCAF officers began to consider the future implications of the Basic Security Plan, especially in relation to how to meet the manpower and equipment requirements for the air defence system. A review of Plan E indicated that it had failed to consider some of the basic, initial requirements of the Basic Security Plan, such as the establishment of radar units and interceptor squadrons,${ }^{55}$ the need for which were already obvious even as Plan E was being drafted. There was another major problem that had to be resolved. Both the Regular RCAF and the Auxiliary could not attract and train sufficient personnel to satisfy even the reduced Plan

\footnotetext{
${ }^{54}$ LAC, RG 24, Vol 5193, File 15-9-124, Part 1, Minutes of the Fifth Meeting of the AMAP Current Plans and Estimates Committee, Held in Room 2511, "A" Building, at $1430 \mathrm{hrs,} 21^{\text {st }}$ August 1947, file S15-9-124 (DOE), dated 29 August 1947.
} 
E requirements. At a senior-level conference in mid-September 1947, Commanding

Officers were told that "of the airmen in the Service many of them are either completely untrained or only partially trained." Amongst the reasons for not achieving recruitment targets were the lack of suitable quarters for personnel, a low rate of pay in comparison to civilian counterparts, misemployment and frequent postings to new locations.

Air Vice Marshal Roy Slemon talked of the need "of finding ways and means of stopping a general exodus by the airmen out of the RCAF." ${ }^{\text {56 }}$ This problem was reinforced by the completion of the Interim Period on 30 September 1947. At that time, the Interim RCAF ceased to exist and simultaneously the active service status of the air force, which had been in effect since 1 September 1939, ended. ${ }^{57}$ The manning level of the air force was at 11,569 at this time ${ }^{58}$ and increased by a meagre eight personnel by the end of the year. ${ }^{59}$ The air force did not expect to remedy their shortage of skilled personnel for some time.$^{60}$ Part of the problem of developing sufficiently skilled personnel was the RCAF's lack of adequately staffed and equipped training facilities. This shortfall was demonstrated by the RCAF's inability to begin its first postwar training of aircrew until November $1947 .{ }^{61}$ One consideration that may have influenced recruiting efforts was the absence of a reasonable career plan. Officers had to serve between $12 \frac{1}{2}$ and $16^{1 / 2}$ years on a short service commission, which could be terminated

\footnotetext{
${ }^{55}$ LAC, RG 24, Vol 5226, file S-19-7-71D, memorandum S.19-7-71D TS 9 (D/AMAP/P) dated 3 July 1947.

${ }^{56}$ LAC, RG 24, Vol 17824, file 840-5, Vol 1, Minutes of a Conference of Air Officers' Commanding, Held at Royal Canadian Air Force Headquarters, Ottawa, on September $15^{\text {th }}-19^{\text {th }}, 1947$, pp. $2-5$.

${ }^{57}$ LAC, RG 24, Vol 17666, file 045-7, Vol 2, RCAF Logbook - A Chronological Outline of the Origin, Growth and Achievement of the Royal Canadian Air Force, Air Historical Section, January 1949, p. 87. ${ }^{58}$ DND, DHH, 180.013 (D5), History of the Royal Canadian Air Force, undated, p. 26.

${ }^{59}$ LAC, RG 24, Vol 17666, file 045-7, Vol 2, no file number or date, document entitled "Department of National Defence - Major Events 1947-1950", p. 4.

${ }^{60}$ LAC, RG 24, Vol 3303, file HQ 280-2-1, letter 27 (SPSO), dated 2 December 1947.

${ }^{61}$ DND, DHH 181.009 (D5917), Manual of Air Force History, dated February 1963, Article 5.01, para 3.
} 
without pension rights, before being eligible for the security offered by a permanent commission. In 1946, only 26 percent of non-flying officers received such an offer. ${ }^{62}$

To address this manning shortfall and as part of the annual development of the Armed Forces Programme for the government, in October 1947 the RCAF and the other Services produced plans for requirements in the event of war. This plan called for a Basic Security Force of 120,000 personnel for the protection of Canada and another 130,000 personnel for a Striking Force. ${ }^{63}$ In order to mobilize to such wartime strength in a reasonable length of time, the plan sought a peacetime establishment of 36,000 Regular, 28,000 Auxiliary and another 12,000 Reserve personnel by $1957 .{ }^{64}$ It went on to argue that, in order to achieve such numbers by 1957 , it was necessary to begin increasing the air force year by year beginning in 1948. As it was, a disproportionate number of air force personnel in 1947 was involved in training new personnel, which necessitated a curtailment of even the reduced operational expectations detailed in Plan E. ${ }^{65}$ To partially remedy this situation, the RCAF sought an additional 3596 personnel during the 1948-49 fiscal year, which would result in the eventual establishment of another interceptor fighter wing with 24 aircraft, another transport squadron with six aircraft and a transport flight to assist with Army requirements. ${ }^{66}$ While no new aircraft were explicitly sought as part of this request, rendering much of this discussion about additional wings and squadrons unnecessary, the continued development of the future CF-100 interceptor was supported, which at least held out promise for eventual additions

\footnotetext{
${ }^{62}$ LAC, RG 24, Vol 3211, file 186-1-11 (Vol 1), RCAF Information Bulletin, No. 32, file number 555-344, entitled "Permanent Commissions Available for Short Service Officers", dated 4 July 1947.

${ }^{63}$ DND, DHH 193.009 (D 53), Box 2, Papers and Meetings, Chiefs of Staff Committee, Vol 71, October 1947, attachment to Extract from Minutes of the $406^{\text {th }}$ Meeting of the Chiefs of Staff Committee, Held on 14 October 1947, entitled "RCAF War Commitments", p.1

${ }^{64} \mathrm{Ibid}$.

${ }^{65}$ Ibid., Part II, p. 1 and Appendix B.
} 
to the RCAF aircraft inventory. ${ }^{67}$ These requirements, along with those from the other Services, were forwarded to Cabinet on 20 October $1947 .^{68}$

\section{Policy Statement on Canada's Defence}

Brooke Claxton, as Minister of National Defence, recognized the need for the political guidance of the three services. On 9 July 1947, he rose in Parliament to report upon National Defence's estimates and established three priorities for the armed forces, specifically:

(1) to defend Canada against aggression;

(2) to assist the civil power in maintaining law and order within the country;

(3) to carry out any undertakings which by our own voluntary act we may assume in co-operation with friendly nations or under any effective plan of collective action under the United Nations. ${ }^{69}$

The themes in Claxton's priorities were familiar to the services. A forerunner of these was included in the Canadian Army's postwar Plan G in 1945, which indicated peacetime roles of training for war, providing the machinery and resources for rapid mobilization, and developing a strike force to execute any policing or punitive role assumed by Canada. Army wartime roles consisted of defending North America,

\footnotetext{
${ }^{66}$ Ibid., Part II, pp. 1 and 3.

${ }^{67}$ Ibid., p. 2.

${ }^{68}$ LAC, RG 24, Vol 6174, File HQ 19-7-79, Vol 1, Memorandum from Chiefs of Staff Committee to the Cabinet Defence Committee, entitled "Armed Forces Programme 1948-49", dated 20 October 1947.

${ }^{69}$ Douglas L. Bland, ed., Canada's National Defence - Volume 1 (Kingston: Queen's University Press, 1997), p. 20.
} 
immediate provision of a striking force and having an expeditionary force ready for deployment. $^{70}$

Claxton went on to identify the looming Cold War threat of the "atomic bomb, jet-propelled planes, long range rockets and higher speed submarines" and advocated working in partnership with other nations to preserve peace. ${ }^{71}$ This declaration imbedded the idea of collective defence in Canadian policy, which was already occurring through the Basic Security Plan.

Claxton also identified 14 defence objects, two of which are relevant here. Specifically, he mandated "[p]rogressively closer co-ordination of the armed services and unification of the Department so as to form a single defence force in which the three armed services work together as a team" and "[j]oint intelligence and planning groups to review defence appreciations and plans". ${ }^{72}$ Both of these measures were implemented and should have contributed to closer collaboration and cooperation between the services. However, in Canada and later in support of the North Atlantic Treaty Organization (NATO), the RCAF was to focus almost exclusively on its fighter-interceptor role, which was featured prominently in the Basic Security Plan. This was markedly different from the air force's first postwar planning efforts, in which the Post War Organization Committee planned to have up to 15 of 44 squadrons assigned to support the other services. Instead, the RCAF increasingly sought and planned to emphasize fighterinterceptors, which served an independent role for which the air force had sole

\footnotetext{
${ }^{70}$ DND, DHist, 112,3M2 (D286), Memorandum HQS $9072-5$ (DMOP), dated 30 June 1945, quoted from Bryan Brulotte, "Visions of Grandeur: Planning for the Canadian Post-war Army, 1944-1947", an unpublished MA thesis in History, Carleton University, Ottawa, 1991, p. 63. According to Brulotte, this was the first instance of the Canadian Army defining its postwar role.

${ }^{71}$ Ibid.

${ }^{72}$ Ibid., p. 24.
} 
responsibility. The RCAF was intent on building a Cold War air force that accentuated its organizational interests.

The creation of fighter-interceptor stations, the establishment of the trans-Canada radar chain and associated work was directly linked to home defence, identified by Claxton as the primary responsibility of the armed forces. These measures were in response not only to the political direction to defend Canada, but also to the Cold War threat that was increasingly entering the political and public consciousness. In some sense, Claxton's statement was the political and public acknowledgement of the new security environment and was representative of the direction of Canada's postwar military efforts for many years to come.

This increased awareness of the Soviet air threat went beyond the military. In 1946, Lester Pearson wrote a Foreign Affairs article on the need for Canada to protect the north. ${ }^{73}$ During a speech, he was bellicose in his opposition to the Soviet Union, denouncing the "crusading and subversive power of communism ... harnessed by a coldblooded, calculating, victoriously powerful Slav empire for its own political purposes." ${ }^{, 74}$ And such sentiment was widely supported by Canadian public opinion, which was anticommunistic and pro-American to begin with. ${ }^{75}$ The Liberal government played to this, "scaring the hell out of the country" through fiery speeches and dire warnings about the threat to democracy. Pearson talked of the USSR as an "oppressor on a scale surpassing even Nazi Germany" and Louis St. Laurent publicly spoke of the threat to freedom and religion posed by communism. ${ }^{76}$ Through such measures, the social and political

73 L.B. Pearson, "Canada Looks Down North." Foreign Affairs, Vol 24, No. 4, July 1946, 628-637.

${ }^{74}$ English, Shadow of Heaven, p. 301.

${ }^{75}$ Whitaker and Marcuse, p. 261.

${ }^{76}$ Ibid., p. 266. 
environments were becoming conditioned to the requirement for a military response to the threat.

One other significant organizational development occurred near the end of the year. During the war, the Ministers of National Defence had been advised by senior boards, called the Army Council, the Naval Board and the Air Council, from within their respective services, which had been dissolved at the end of hostilities. At the recommendation of the RCAF, in July 1947, the Chiefs of Staff approach Claxton about reconstituting these bodies. ${ }^{77}$ In October 1947, the Minister of National Defence allowed their re-creation. ${ }^{78}$ The return of the Air Council helped improve future management and oversight of the RCAF by concentrating senior force leadership in a single body. Council members also served as advisors to the minister on RCAF-related matters.

\section{Regular and Auxiliary RCAF Shortfalls}

In early 1948 , the RCAF realized that no decision had been made about carrying out the Master Implementation Plan of the Basic Security Plan. Moreover, it was evident that additional personnel would be required to begin these activities. ${ }^{79}$ The Cabinet Defence Committee was approached, resulting in direction that the top priority was to be given to creating the defensive air grid for eastern Canada. Discussion by the renamed Current Planning Committee led to the decision to begin implementing the Basic Security

\footnotetext{
${ }^{77}$ DND, DHH, 193.009 (D53), Box 2, 1947, Papers and Meetings, Chiefs of Staff Committee, Vol 68, July 1947, extract from Minutes of the $397^{\text {th }}$ Meeting of Chiefs of Staff Committee held Wednesday 30 July 1947.

${ }^{78}$ DND, DHH 193.009 (D53), Box 2, 1947, Papers and Meetings, Chief of Staff Committee, file CGS: Copies of Memoranda, Chiefs of Staff Committee, Vol 71, October 1947, letter file number CSC 5-15, entitled "Terms of Reference: Naval Board, Army and Air Councils", dated 30 October 1947, from Group Captain W.W. Bean, Secretary, to Brooke Claxton, Minister of National Defence.
} 
Plan by establishing a fighter training unit in St Hubert, Quebec and fighter bases in St Joli and Bagotville, Quebec and Chatham, New Brunswick, along with the necessary supporting ground control stations. ${ }^{80}$ However, the establishment of these units had to be put off until between 1 September 1948 and 1 February 1949 because of personnel shortages. ${ }^{81}$

The RCAF continued to have difficulty attracting suitable candidates. A survey was conducted of veterans with combat experience who were attending university and it was found that these students believed that "employment in the civilian field was considerably more attractive than that presented by the RCAF." ${ }^{82}$ A proposed solution was to develop a program in which undergraduates would be enrolled and have their tuition, books and instruments paid for, as well as being provided a salary for their final year. ${ }^{83}$ This initiative proved to have limited success in reversing the air force's recruitment problems, as it was authorized to taken on only 75 candidates for each of the academic years 1948-49 and 1949-50 and was reduced to 50 for the year after that. ${ }^{84}$ University education continued to be a desirable attribute of officers. The Minister of National Defence Claxton was critical of the level of educational attained by some

\footnotetext{
${ }^{79}$ LAC, RG 24, Vol 5193, file 15-9-124, Part 1, Minutes of the First Meeting of the Current Plans Committee, Held in Room 2511, "A" Building, at 0930 hrs, $26^{\text {th }}$ January, 1948, file number S15-9-124 (DOE), 17 January 1948.

${ }^{80}$ LAC, RG 24, Vol 5193, file 15-9-124, Part 1, Minutes of the Sixth Meeting of the Current Plans Committee, Held in Room 2511, "A" Building, at 1430 hrs, $22^{\text {nd }}$ April, 1948, file number S15-9-124 (DOE), undated.

${ }^{81}$ LAC, RG 24, Vol 5193, file 15-9-124, Part 1, Minutes of the Seventh Meeting of the Current Plans Committee, Held in Room 2511, "A" Building, at 1030 hrs, $29^{\text {th }}$ April, 1948, file number S15-9-124 (DOE), undated.

${ }^{82}$ LAC, RG 24, Vol 5193, file HQ S 15-9-134, Letter 185-1-10 (DSM), dated 11 February 1948 from the MND to Treasury Board.

${ }^{83}$ Ibid.

${ }^{84}$ Ibid.
} 
officers and observed that postwar rates of pay for officers were set under the assumption of a university education. ${ }^{85}$

At the same time, the air force was encountering continuing problems with the establishment of the RCAF Auxiliary. Air Commodore R.C. Ripley, while acting as Chief of the Air Staff, indicated that "[p]rogress in formation and build-up of Auxiliary Squadrons is not satisfactory" and proposed a conference to explore the reasons why. ${ }^{86}$ In preparation for this conference, Air Vice Marshal Slemon attributed the problems to recruiting efforts and the training of ground crew. He also questioned whether the auxiliary squadrons were making the best use of the assistance made available to them in these areas. ${ }^{87}$ In support of this assertion, Slemon provided data indicating that while Plan E had authorized auxiliary squadrons to have 444 officers and 2461 airmen, they in fact had only 270 officers and 539 men. ${ }^{88}$ Steps had to be taken to correct these shortfalls.

The Air Member for Personnel, Air Vice Marshal J.L. Plant, suggested that there was a lack of motivation for civilians to join Auxiliary squadron because of inadequate and unattractive accommodations. There was also insufficient training equipment, which contributed to the maintenance problems for the Auxiliary. Another factor affecting recruitment for Plant was a national lethargy against working as part of ground crew, which was considered unattractive. Flying had more cachet. Recruiting efforts were also hindered by insufficient advertising and poor interaction with Air Cadets, high schools,

\footnotetext{
${ }^{85}$ LAC, RG 24, Vol 3211, file 186-1-1 (Vol 2), Memorandum 186-1-11 (CAS), entitled "Basic Qualifications for Officers", dated 23 September 1948.

${ }^{86}$ LAC, RG 24, Vol 5193, File HQ S 15-9-137, memorandum 191-3-2 (CAS), entitled "RCAF Auxiliary", dated 27 April 1948, from CAS to AMAP, AMOT, AMTS and AMP.

${ }^{87}$ LAC, RG 24, memorandum 191-3-2, entitled "RCAF Auxiliary Conference", dated 29 April 1948, from AMOT to A/CAS.

${ }_{88}^{88}$ Ibid., unreferenced attached minute sheet from PC 3-4 to PC 3 dated 29 April 1948.
} 
technical schools and other sources of potential recruits. Once able to attract someone, problems were encountered with personnel achieving qualifications and there was a sense that the Auxiliary trade structure was too stringent. ${ }^{89}$ These problems posed difficulties with establishing an effective Auxiliary RCAF, which reasonably called into question its ability to take the operational role foreseen for it in Plan E.

This led Plant to recommend that the Auxiliary role be changed "from first line defence to a reserve organization designed to augment the Regular in a period of emergency." ${ }^{90}$ At a special meeting called to discuss this issue, senior RCAF leaders weighed the future of the RCAF Auxiliary, with many agreeing with Plant about the poor quality of accommodations and lack of equipment. The Acting Chief of the Air Staff, Air Vice Marshal A.L. Morfee, indicated that the Auxiliary could not meet its responsibilities to act as a first-line reserve of combat squadrons and that the Reserve Force was nothing more than a list of names. ${ }^{91}$ Of the ten squadrons planned for 1948-49, only eight had been stood-up and each of these was badly under strength. While plans called for another five squadrons to be established soon, this appeared unlikely for a variety of reasons, including the lack of suitable sites for airfields capable of accommodating the emerging jet propulsion technology. ${ }^{92}$ There was a consensus at the meeting that the present role of the Auxiliary was unattainable and that its focus should be on non-operational roles. Slemon was able to overcome this pessimism and convinced attendees that it would be better to increase the level of Regular RCAF support to the Auxiliary, largely in the area

\footnotetext{
${ }^{89}$ LAC, RG 24, Vol 5193, file HQ S 15-9-137, memorandum 191-3-2 (AMP), entitled "RCAF Auxiliary Conference", dated 6 May 1948, from AMP to CAS.

${ }^{90}$ Ibid.

${ }^{91}$ LAC, RG 24, file HQ S 15-9-137, Minutes of a Special Meeting at Air Force Headquarters, $5^{\text {th }}$ May, 1948, to Discuss Problems in Connection with the RCAF Auxiliary and Reserve, p. 2.

${ }_{92}$ Ibid.
} 
of aircraft maintenance, which would allow Auxiliary personnel to concentrate on becoming operationally proficient and thereby be able to fill an operational role. The Regular RCAF ground crew could also be used to train Auxiliary personnel at a less intense pace, with the intent of eventually making the Auxiliary self-sufficient. ${ }^{93}$ This approach was endorsed.

These developments signified the beginning of a major change in thinking for the RCAF. In the past, in much the same manner as the relationship between the Canadian Army and the Militia, the Regular RCAF was considered a training force for the Auxiliary and as a basis for expansion in time of crisis. The Post War Organizing Committee explicitly sought to emphasize the training role for the Regular RCAF in the original postwar plan and gave responsibility for the air defence role to the Auxiliary. But there was a difference between what the Auxiliary was asked to do and what it could accomplish. It continuously failed to meet operational and maintenance standards, and was unable to take in sufficient personnel to meet recruitment goals. Part of the responsibility for this rests with the Regular RCAF, which was slow to organize the postwar Auxiliary and failed to provide adequate support. However, some of these shortfalls by the Regular RCAF were beyond its control; it had limited aircraft to provide the Auxiliary and had difficulty satisfying its own operational commitments. Through Slemon's intervention, the Auxiliary was provided with another opportunity to have a meaningful role. But this was a temporary reprieve. Air Vice Marshal Plant's recommendation that the Auxiliary be placed in a non-operational role gained support in the future.

\footnotetext{
${ }^{93}$ Ibid., p. 6.
} 
Various Auxiliary squadrons were unhappy with the shortage of equipment and perceived lack of interest and support from the Regular RCAF. Squadrons in Montreal and Vancouver particularly agitated for changes, which the Regular RCAF attributed to an inability to understand the gravity of problems within both forces. In order to resolve some of these issues, a conference was proposed, but the Regular RCAF did not hold out much hope that it would accomplish much. ${ }^{94}$ The conference took place on 16 October 1948 and was chaired by Slemon. He had obviously changed his mind from a few months earlier. After noting that the Auxiliary had been entrusted postwar with an operational first line role in providing air defence for Canada, he observed that "because of the limited time which Auxiliary personnel could devote to Air Force activities, the squadrons were incapable of achieving such a high standard of operational preparedness under the present organization." Conference attendees, including the Commanding Officers of the Auxiliary Squadrons, obviously agreed with Slemon, as the following proposal to change the role of the Auxiliary was adopted unanimously:

To provide a first line Reserve of fully organized, manned and equipped squadrons, trained to a standard which will permit them to be mobilized and become operational by M plus 90 days. ${ }^{95}$

In this instance, $M$ refers to the date that the government mobilizes the armed forces in response to an emergency. This new Auxiliary responsibility to achieve an operational standard by 90 days after mobilization represented a much lower training standard than had been required previously. The RCAF still considered the Auxiliary as part of air

\footnotetext{
${ }^{94}$ LAC, RG 24, Vol 17826, file 840-91, Vol 1, Memorandum 252-25-6 (DAT) entitled "Proposed AFHQ Conference - Auxiliary Squadron Commanding Officers", dated 30 June 1948.

${ }^{95}$ LAC, RG 24, Vol 17826, file 840-91, Vol 1, Memorandum 150-64/0, entitled "First Auxiliary Squadron CO Conference - 16 Oct 48", dated 6 November 1948, from AVM Slemon, AMOT to AVM Middleton, CAC.
} 
force planning, but with reduced roles and responsibilities. The Auxiliary would not be given a front-line operational role again.

\section{The Strategic Environment}

In June 1948, the United States sought to revise the Joint Appreciation. In addition to amending the likely date for the first explosion of an atomic bomb by the Soviet Union to mid-1950 from 1953, the US wanted, in the opinion of Canadian intelligence personnel, to amend the Appreciation with "superfluous material, questionable generalizations". The Americans wanted to indicate an enhanced ability by the Soviets to attack North American targets. While the proposed change in date for a Soviet atomic bomb was not challenged, the Canadians did not have the same confidence in the claim about attacks on North America. Concern was also expressed that, while it had been agreed to develop these Appreciations jointly, the Americans had presented the already revised Appreciation to the Canadians for review. ${ }^{96}$ As would happen from time to time, the Chiefs of Staff Committee was not willing to accede to perceived American overstatements of the threat and decided to accept the Canadian interpretation. The committee directed that this difference of opinion be brought to the attention of the American members of the MCC. ${ }^{97}$

The Joint Intelligence Committee within National Defence Headquarters sought authority in July 1948 to produce an updated intelligence assessment, which would

\footnotetext{
${ }^{96}$ DND, DHH 193.009 (D 53), Box 4, July 1948-March 1949, Papers and Meetings, Vol 80, File July 1948, Chiefs of Staff Committee Papers, enclosure to Extract from Minutes of the $426^{\text {th }}$ Meeting of the Chiefs of Staff Committee Held on 8 July 1948, enclosure JIC 5/58 (final), entitled "Report on the Acceptability of the American Revisions to the Appreciation of the Requirements of Canada - United States Security dated $23^{\text {rd }}$ May 1946", p.1.
} 
consider the long-term threat posed by the Soviet Union. In an effort to take a broad view of the issues associated with the production of such an assessment, permission was sought to obtain advice on economic and demographic issues from the Bank of Canada, Department of Trade and Commerce, and Department of Finance. ${ }^{98}$ This requirement was soon echoed by the MCC, which solicited authority for the Joint Intelligence Committee to work with the United States Joint Intelligence Committee to produce a single, agreed upon threat appreciation in support of long-term planning, including the Basic Security Plan. A target date for completion of this assessment was set at 1 October $1948 .^{99}$ This request was considered and approved at a Chiefs of Staff Committee meeting on 23 August. ${ }^{100}$

On 21 October 1948, the updated joint Canada-United States intelligence assessment was released, which included some important differences from the assessment released during March 1947. Entitled "Soviet Capabilities and Probable Courses of Action against Canada, the United States, and the Areas Adjacent Thereto, 1949-1956", this document was prepared specifically to support the Basic Security Plan and to

\footnotetext{
${ }^{97}$ DND, DHH 193.009 (D 53), Box 4, July 1948-March 1949, Papers and Meetings, Vol 80, File July 1948, Chiefs of Staff Committee Papers, Extract from Minutes of the $426^{\text {th }}$ Meeting of the Chiefs of Staff Committee Held on 8 July 1948, para 5.

${ }^{98}$ DND, DHH 193.009 (D 53), Box 4, July 1948-March 1949, Papers and Meetings, Vol 80, File August 1948, Chiefs of Staff Committee Papers, no file number, entitled "Memorandum for the Chiefs of the Staff Committee", dated 30 July 1948, from F.W.T. Lucas, Lt-Cdr, Secretary, Joint Intelligence Committee to Secretary, Chiefs of the Staff Committee.

${ }_{99}$ DND, DHH 193.009 (D 53), Box 4, July 1948-March 1949, Papers and Meetings, Vol 80, File August 1948, Chiefs of Staff Committee Papers, no file number, entitled "The Requirement for a Combined Canada-United States Long Term Strategic Estimate (Appreciation)", dated 20 August 1948, from R.F. Walker, Major, Acting Secretary, Canadian Section, Military Cooperation Committee to Secretary, Chiefs of Staff Committee.

${ }^{100}$ DND, DHH 193.009 (D 53), Box 4, July 1948-March 1949, Papers and Meetings, Vol 80, File August 1948, Chiefs of Staff Committee Papers, Extract from Minutes of $429^{\text {th }}$ Meeting of the Chiefs of Staff Committee, Held on 23 August 1948.
} 
estimate, once again, the warning time expected should the Soviet Union attack. ${ }^{101}$ Using the latest anticipated date for the development of an atomic bomb by the Soviet Union, this assessment was divided into two parts, with the first part spanning the years 19491952 and the second part addressing 1953-1956, by which time it was assumed that the USSR would have the bomb.

Regarding the 1949-1952 timeframe, the new intelligence assessment suggested that the Soviet Union and its satellites would demonstrate increasing economic power, producing substantially more than 12,000 aircraft, plus 3 heavy cruisers, 11 destroyers and 37 submarines, as well as meaningful numbers of armoured combat vehicles and merchant shipping. ${ }^{102}$ The Soviet army was estimated at 2.5 million personnel, organized into 174 divisions, including 20 tank divisions, each with 250 tanks and 20 heavy selfpropelled guns. ${ }^{103}$ For its air force, the USSR was believed to have between 15,000 and 17,000 operational aircraft, involving a total 500,000 personnel. In between $9,000-$ 10,000 of these aircraft were dedicated to a tactical role in support of the army, providing close air support. About another 1,800 were used in an interceptor role. Of particular interest to the RCAF air defence scheme, the long-range bomber force, consisting of about another 1,800 aircraft, were organized into three air armies reporting directly to the Ministry of Armed Forces. This suggested the degree of interest the Soviet High Command had in strategic air operations. ${ }^{104}$ Approximately 200 of these bombers were similar to the B-29, with an operational radius of around 1600 miles return or to a

\footnotetext{
${ }^{101}$ LAC 24, RG 24, Vol 8145, file 1480-29, file number A.C.A.I. 5 (Final), An Agreed Canada-United States Estimate entitled "Soviet Capabilities and Probable Courses of Action against Canada, the United States, and the Areas Adjacent Thereto, 1949-1956", dated 21 October 1948, p. 1.

${ }^{102}$ Ibid., pp. 6-7.

${ }^{103}$ Ibid., p. 7.

104 Ibid., p. 8.
} 
maximum of around 4000 miles one way, while carrying a 10,000 pound bomb load. Another $150 \mathrm{~B}-29$ type bombers were thought to be used in a training role and it was estimated that the Soviet Union would have between 300-400 of these bombers in operational units by the end of 1949 . The remaining aircraft was a variety of multiengine bombers with varying ranges. ${ }^{105}$ The Soviet navy also had a substantial number of operational ships in service. All in all, the USSR armed forces were large and capable of posing a significant threat.

In assessing the combat effectiveness of the long-range bomber force, the October threat appreciation indicated that Soviet crews did not have much experience conducting offensive operations over long distances. This kind of mission required a significant training effort, which was believed to be underway already. ${ }^{106}$ This was relevant because all important industrial targets in Canada and the United States could be reached with the Soviet's B-29 equivalent on a one-way mission and from Puget Sound to Edmonton could be reached during a two-way mission. ${ }^{107}$

Soviet researchers and scientists were thought to be giving considerable attention to atomic bomb development. Although there had been advances in other areas of military capability, the threat assessment suggested that no substantive change had occurred since the previous year's assessment. There was a possibility of a Soviet atomic test bomb in mid-1950, but it was more likely that this would not take place until 1953. Should the Soviet bomb be developed in 1950, a stockpile of around 50 bombs could be expected by 1955; should the first atomic bomb be available to the USSR in 1953, then the 1955 stockpile could be expected to be around 20 bombs. Soviet biological and

\footnotetext{
${ }^{105}$ Ibid., pp. 8-9.

${ }^{106}$ Ibid., p. 11.
} 
chemical weapons remained a concern for Canada and the United States throughout the period under consideration, with their effectiveness limited only by their delivery system. $^{108}$

In extending its review to the 1953-1956 period, the October intelligence appreciations painted a darker picture of the threat. It began by indicating that any Soviet economic difficulties being experienced in 1949 would be overcome by 1956 . Improvements to the manufacturing sector were expected to result in corresponding increases to the armament industries. This enhanced industrial capability would result in a more capable and larger Soviet air force, but the intelligence appreciation prudently deferred until later attempting to estimate what this would mean for the air force. The appreciation did, however, indicate that one of the areas of improvement would be in long-range bombing capability, although it was believed that this future generation of Soviet bombers would be less capable than their North American counterparts. This enhanced performance was expected to translate into greater penetration of the North American industrial heartland during any bombing attacks. ${ }^{109}$ In reference to atomic weapons, there was no change to the forecast provided as part of the assessment for the 1949-1952 timeframe.

These considerations led the Canadian and American intelligence community to conclude that:

Concerted air attack is a further course of action which would be open to the Soviet Union toward the latter part of the period. Its object would be the reduction of Canadian and United States war potential. Should an operational quantity of atomic bombs become available to the Soviet Union, it is considered that the expansion of the Soviet long-range air

\footnotetext{
${ }^{107}$ Ibid., p. 13.

108 Ibid., pp. 12-14.

${ }^{109}$ Ibid., pp. 18-22.
} 
force and increased Soviet capabilities in chemical and biological warfare would make concerted air attack against targets in Canada and the United States a sound course of action. Although for the most part, one-way missions would still be necessary, it is believed that this would not deter the Soviet leaders. ${ }^{110}$

This document provided the background and context for Curtis as he prepared his recommendations for domestic air defence and an expeditionary force to the Cabinet Defence Committee. The intelligence appreciation described a growing danger from the Soviet Union, which was seen as likely capable of large scale attacks with atomic weapons across much of North America within eight years. Recognition of this threat contributed to a political environment more favourable to defence spending.

\section{New Government Direction}

Before the RCAF was able to present its new plan, a number of developments made its acceptance more likely. At a 6 October 1948 meeting, the Committee was briefed by Minister of National Defence Brooke Claxton and the recently appointed Secretary of State for External Affairs, Lester Pearson, concerning recent discussions in Washington related to the requirement for a new common security alliance as a response to Soviet actions. Pearson supported this initiative and observed that in order for Canada to participate meaningfully, the Canadian military had to be increased in numbers and equipment. While this implied a significant increase to defence expenditures, Pearson thought that such spending would be required in any case should the world situation deteriorate further. Claxton supported this viewpoint, also noting that Canada should be prepared to equip itself based upon American pattern equipment so that British

\footnotetext{
${ }^{110}$ Ibid., pp. 23-24.
} 
equipment would be available for usage in Europe. Defence Committee reaction to this briefing was favourable, although Douglas Abbott, the Minister of Finance, observed that there would be a requirement to consider carefully the financial implications of such actions in order to ensure that Canada did not overextend itself. The Cabinet Defence Committee supported the idea of participation in the new alliance as well as that of increasing defence expenditures in order to respond to the evolving threat. ${ }^{111}$

A factor in this support may have been the absence of Mackenzie King from the Committee. As noted earlier, in 1946 he assumed the lead of the Cabinet Defence Committee in part because of concerns about the level of defence spending. Mackenzie King had resigned as leader of the Liberal Party of Canada a few months prior to this October 1948 meeting. Louis St. Laurent assumed the responsibility as Acting Prime Minister pending the next federal election after Mackenzie King resigned as Prime Minister on 15 November 1948. St. Laurent was a devout Roman Catholic and distrusted communists. Although a lawyer, he felt no obligation to protect the civil liberties of Canadian communists. He was also an internationalist, willing to work with other nations towards a common goal. ${ }^{112}$ As Prime Minister, St. Laurent presided over the Cabinet Defence Committee and supported Canadian participation in establishing a new security alliance, which came into being the following year as the North Atlantic Alliance. St. Laurent clearly had the potential to be more supportive of enhanced defence measures than his predecessor.

Subsequent to the 6 October meeting and as part of their annual budget submissions to the Committee, the service chiefs were invited to identify measures that

\footnotetext{
${ }^{111}$ LAC, RG 2 A 5a, Vol 2654, Minutes of Cabinet Meeting, dated 6 October 1948.

112 English, Shadow of Heaven, pp. 315-316.
} 
would lead to a more robust defence capability. On behalf of the air force, on 8 October Air Vice Marshal Curtis described the need for sufficient aircraft to defend not just Canadian borders but also to provide an air expeditionary force and to support the Canadian Army on foreign soil. In fighters alone, Curtis described the eventual requirement for an incredible total of 556 fighters, consisting of 300 all-weather jet fighters and 256 jet day fighters. This would be achieved through a combination of supporting Canadian development and production of a long range, all-weather aircraft and initially purchasing and then producing within Canada the day fighters. The Cabinet Defence Committee took this briefing under advisement, pending examination of the costs. It also authorized Curtis to explore the possibility of acquiring an American-built aircraft to serve as the day fighter. ${ }^{113}$

Returning to the Cabinet Defence Committee at the end of the month, Curtis detailed the steps needed to achieve the first part of this expansion of the air force. Given the level of support already provided to the military at the early October meeting, there was reason for optimism that the government would have money for the RCAF. Delaying for a while the full case for the 556 fighters, Curtis opened his briefing by describing the worldwide shortage of fighters in the offensive and defensive roles. This shortfall included Canada, which only had a few Vampires that were limited to daylight operations and for which there were few spares, limited radar and little ammunition. In the event of an emergency, Canada would be ill-prepared to field a credible force during the first year. Curtis advocated the establishment of an aircraft procurement programme,

\footnotetext{
${ }^{113}$ LAC, RG 2, Vol 2748, Minutes of the $47^{\text {th }}$ Meeting of the Cabinet Defence Committee, dated 8 October 1948 and DND, DHH, Raymont Papers, 73/1223, File 1820, Minutes of the $67^{\text {th }}$ Meeting of the Air Members, held at 1500 hours, Monday, 14 February 1949, p. 4.
} 
which would include an all-weather fighter, a day fighter and troop carrying aircraft. ${ }^{114}$ He asked for approval-in-principle for such a programme, with an initial production of 100 all-weather Avro CF-100 Canucks in Canada and the purchase of 56 North American F-86 Sabres from American production lines for day fighting. He also requested that the Canadian government negotiate with American authorities about moving the production of the F-86 and the C-119 transport aircraft to Canada, after which an initial order of another 100 Sabres and 40 troop carriers would be placed. These measures would cost about $\$ 195$ million, with future commitment authority amounting to about $\$ 41$ million. ${ }^{115}$ As part of his presentation, Curtis expressed concerned that the United States would take action to build its portion of the air defence system and that the failure of Canada to do likewise would result in the positioning of American forces on Canadian territory during an emergency. ${ }^{116}$ This contributed to his asking the Cabinet Defence Committee for another $\$ 17.75$ million for new construction and navigation aids. ${ }^{117}$

The Cabinet Defence Committee discussed these requests at length. Acting Prime Minister St. Laurent questioned whether the purchase of the American F-86s, after already having the British Vampires, would be a good practice. If anything, he preferred that the RCAF standardize just on American equipment. Curtis defended the two aircraft types, since it meant that there would be more than one source for spares. ${ }^{118}$ The Minister of Trade and Commerce, C.D. Howe, who had significant experience during the war in overseeing the production of military equipment, thought that the costs were high,

\footnotetext{
${ }^{114}$ LAC, RG 2, Vol 2748, Minutes of the $51^{\text {st }}$ Meeting of the Cabinet Defence Committee, dated 30 October 1948, pp. 2-3.

${ }^{115}$ Ibid., pp. 5-6.

${ }^{116}$ DND, DHH 181.004 (D 46), Summary of Requirements for RCAF Plan F, 1950-51, p. 1-2.

${ }^{117}$ LAC, RG 2, Vol 2748, Minutes of the $51^{\text {st }}$ Meeting of the Cabinet Defence Committee, dated 30 October 1948, p. 3.

${ }^{118}$ Ibid., p. 4.
} 
likely because initial tooling expenses were charged against the first order. He suggested that a better approach would be for the government to defray tooling costs, which would probably open the manufacturer to accepting a contract for fewer aircraft. Howe also anticipated that the troop transporters could be acquired for less because a Canadian manufacturer would be ready to spread costs over a longer run on speculation that additional orders would follow. ${ }^{119}$

Claxton agreed with the majority of Howe's comments and argued that the most urgent matter was to arrange for the tooling of the new production lines for an order of 10 all-weather fighters. For this purpose, he proposed that \$3.1 million be set aside. He then wanted to arrange for $35 \mathrm{~F} 86$ Sabres from the Americans and to begin negotiations for Canadian manufacturing rights for this aircraft and the C119 troop carrier. In reference to the building and navigational aid programme requested by Curtis, Claxton expressed support and identified the model interceptor system as a priority. The Cabinet Defence Committee approved expenditures in line with Claxton's recommendations. ${ }^{120}$ This series of events is indicative of the new political environment in which the RCAF operated. The departure of Mackenzie King and the succession of Louis St. Laurent as Prime Minister after the general election of 15 November 1948 resulted in more sympathetic hearings at the Cabinet Defence Committee. This was assisted by the arrival of Lester Pearson as Secretary of State for External Affairs, who was also supportive of the military. This does not imply that the political leadership gave the RCAF everything it asked for; this was not the case. But it was evident that matters of national defence were receiving greater attention, likely helped by the awareness

\footnotetext{
${ }^{119}$ Ibid.

${ }^{120}$ Ibid., pp. 5-6.
} 
generated by the production of the various intelligence assessments. It was in this setting that the RCAF prepared its next generation of plans.

\section{A New Beginning - Plan F}

With the new intelligence appreciation and ongoing political oversight as background, the RCAF produced the next edition of their main plan. In the period leading up to September 1948, RCAF planners sought to articulate the measures needed to satisfy the Basic Security Plan. Similar to the phased approach taken during the October 1947 Armed Forces Programme submission and as detailed in Plan E, a progressive build-up was advocated. In this year's version, planners sought an eventual operational strength of 20 Regular and 12 Reserve Squadrons. Initially, the air defence role would remain primarily an Auxiliary task, with the Regular RCAF being allotted two fighter squadrons and the Auxiliary nine. By the fiscal year 1953-54, fighter squadrons were planned to total 19, nine of which were to be Regular RCAF. An aircraft procurement programme was also sought to replace aging airframes and to promote Canadian aircraft industry. By 31 March 1954, the air force intended to have a total of 344 aircraft, 188 of which were to be fighters. The attachment the RCAF had for the bombing role surfaced again, with a single eight plane medium bomber squadron planned for 1952-53. Moreover, the requirement for Canada to build its portion of the air defence system was emphasized throughout Plan F. ${ }^{121}$

Plan F was easily the most comprehensive RCAF plan to date. It included a detailed examination of operational and training requirements and provided extensive

${ }^{121}$ DND, DHH 181.004 (D 46), Summary of Requirements for RCAF Plan F, pp. 1-2 and Section B, Tab 1. 
expenditure proposals, which allowed the government to identify the cost of each air force role. As an example of the completeness of Plan F, regarding the air interception and air warning role, it identified the requirement for the establishment of an Air Defence Command Headquarters, 17 interceptor squadrons (9 Regular and 8 Auxiliary), and 17 Air Control and Warning units. Because the current threat appreciations did not anticipate much of a chance for air attack without warning before 1956, the rollout of aircraft and squadrons as provided for in the plan was expected to provide sufficient time to develop, train and field the capabilities required to handle the threat of attack to North America. ${ }^{122}$ The implementation strategy for squadron and aircraft demonstrated this and an example of the level of details contained in the plan is provided in Table 5.

In support of Maritime Forces against the growing Soviet submarine threat, Plan F identified an RCAF requirement for three maritime squadrons. The Canadian Army would receive help from the air force through the establishment of three troop carrier squadrons and two tactical bomber squadrons. The latter responsibility was assigned to the Auxiliary. The requirement for five transport squadrons, a Search and Rescue capability, support to photographic operations, and a training organization suitable to support the entirety of air force needs was also articulated. ${ }^{123}$ New headquarters were established in Halifax for Maritime Group (formerly 10 Group), Winnipeg for Tactical Group (formerly 11 Group) and Search and Rescue Coordination, Rockcliffe, Ontario for Air Transport Command and Trenton, Ontario for Training Command (formerly the home of Central Air Command). An Air Defence Group headquarters was initially set up

\footnotetext{
122 Ibid., p. 2.

${ }^{123}$ Ibid., pp. 2-3.
} 
Table 5: Plan F Squadron Allocation ${ }^{124}$

\begin{tabular}{|c|c|c|c|c|c|c|c|}
\hline Type & Role & Planned & $1949 / 50$ & $1950 / 51$ & $1951 / 52$ & $1952 / 53$ & $1953 / 54$ \\
\hline Fighter & $\begin{array}{c}\text { Air } \\
\text { Defence } \\
\text { and } \\
\text { Tactical }\end{array}$ & $\begin{array}{c}\text { Present } \\
12 \\
\text { Wartime- } \\
25\end{array}$ & $\begin{array}{c}\text { Regular } \\
2 \\
\text { Auxiliary } \\
9\end{array}$ & $\begin{array}{c}\text { Regular } \\
4 \\
\text { Auxiliary } \\
10\end{array}$ & $\begin{array}{c}\text { Regular } \\
7 \\
\text { Auxiliary } \\
10\end{array}$ & $\begin{array}{c}\text { Regular } \\
7 \\
\text { Auxiliary } \\
10\end{array}$ & $\begin{array}{c}\text { Regular } \\
9 \\
\text { Auxiliary } \\
10\end{array}$ \\
\hline $\begin{array}{l}\text { Tactical } \\
\text { Bomber }\end{array}$ & Tactical & $\begin{array}{c}\text { Present } \\
8 \\
\text { Wartime } \\
16\end{array}$ & $\begin{array}{c}\text { Auxiliary } \\
2\end{array}$ & $\begin{array}{c}\text { Auxiliary } \\
2\end{array}$ & $\begin{array}{c}\text { Auxiliary } \\
2\end{array}$ & $\begin{array}{c}\text { Auxiliary } \\
2\end{array}$ & $\begin{array}{c}\text { Auxiliary } \\
2\end{array}$ \\
\hline Bomber & Medium & $\begin{array}{c}\text { Present } \\
8 \\
\text { Wartime } \\
12 \\
\end{array}$ & & & & $\begin{array}{c}\text { Regular } \\
1\end{array}$ & $\begin{array}{c}\text { Regular } \\
1\end{array}$ \\
\hline $\begin{array}{l}\text { Mar- } \\
\text { itime }\end{array}$ & $\begin{array}{l}\text { Mar- } \\
\text { itime }\end{array}$ & $\begin{array}{c}\text { Present } \\
12 \\
\text { Wartime } \\
12\end{array}$ & $\begin{array}{c}\text { Regular } \\
1\end{array}$ & $\begin{array}{c}\text { Regular } \\
2\end{array}$ & $\begin{array}{c}\text { Regular } \\
2\end{array}$ & $\begin{array}{c}\text { Regular } \\
2\end{array}$ & $\begin{array}{c}\text { Regular } \\
3\end{array}$ \\
\hline $\begin{array}{c}\text { Trans- } \\
\text { port }\end{array}$ & $\begin{array}{c}\text { Trans- } \\
\text { port }\end{array}$ & $\begin{array}{c}\text { Present } \\
16 \\
\text { Wartime } \\
16\end{array}$ & $\underset{2}{\text { Regular }}$ & $\underset{2}{\text { Regular }}$ & $\underset{3}{\text { Regular }}$ & $\underset{3}{\text { Regular }}$ & $\underset{3}{\text { Regular }}$ \\
\hline $\begin{array}{l}\text { Long } \\
\text { Range } \\
\text { Trans- } \\
\text { port }\end{array}$ & $\begin{array}{c}\text { Trans- } \\
\text { port }\end{array}$ & $\begin{array}{c}\text { Present } \\
12 \\
\text { Wartime } \\
12\end{array}$ & $\underset{1}{\text { Regular }}$ & $\underset{1}{\text { Regular }}$ & $\begin{array}{c}\text { Regular } \\
1\end{array}$ & $\begin{array}{c}\text { Regular } \\
1\end{array}$ & $\begin{array}{c}\text { Regular } \\
1\end{array}$ \\
\hline $\begin{array}{l}\text { Trans- } \\
\text { port } \\
\text { Survey }\end{array}$ & $\begin{array}{l}\text { Photo- } \\
\text { graphy }\end{array}$ & $\begin{array}{c}\text { Present } \\
12 \\
\text { Wartime } \\
0\end{array}$ & $\begin{array}{c}\text { Regular } \\
1\end{array}$ & $\begin{array}{c}\text { Regular } \\
1\end{array}$ & $\begin{array}{c}\text { Regular } \\
1\end{array}$ & $\begin{array}{c}\text { Regular } \\
1\end{array}$ & $\begin{array}{c}\text { Regular } \\
1\end{array}$ \\
\hline $\begin{array}{l}\text { Long } \\
\text { Range } \\
\text { Recce }\end{array}$ & $\begin{array}{l}\text { Photo- } \\
\text { graphy }\end{array}$ & $\begin{array}{c}\text { Present } \\
12 \\
\text { Wartime } \\
12\end{array}$ & $\begin{array}{c}\text { Regular } \\
2\end{array}$ & $\begin{array}{c}\text { Regular } \\
2\end{array}$ & $\underset{2}{\text { Regular }}$ & $\begin{array}{c}\text { Regular } \\
2\end{array}$ & $\underset{2}{\text { Regular }}$ \\
\hline Total & & & $\begin{array}{c}\text { Regular } \\
9 \\
\text { Auxiliary } \\
11\end{array}$ & $\begin{array}{c}\text { Regular } \\
12 \\
\text { Auxiliary } \\
12\end{array}$ & $\begin{array}{c}\text { Regular } \\
16 \\
\text { Auxiliary } \\
12\end{array}$ & $\begin{array}{c}\text { Regular } \\
17 \\
\text { Auxiliary } \\
12\end{array}$ & $\begin{array}{c}\text { Regular } \\
20 \\
\text { Auxiliary } \\
12\end{array}$ \\
\hline
\end{tabular}

at RCAF Headquarters in Ottawa, but was later moved to St. Hubert, Quebec. Figure 5 shows the distribution of RCAF headquarters under Plan F.

${ }^{124}$ Ibid., Section B, Tab 1. 


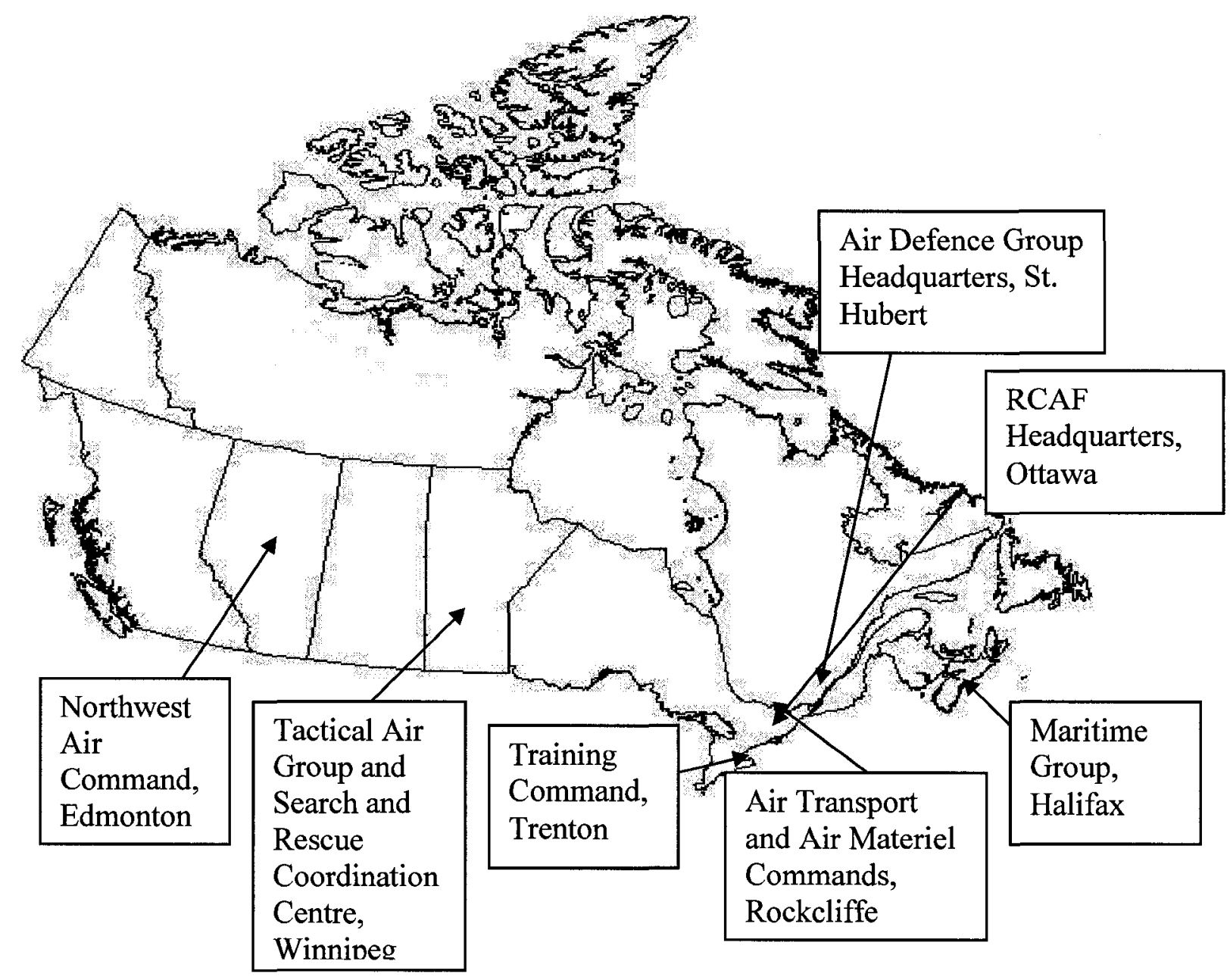

In order to achieve these goals, an eventual ceiling of 35,000 Regular and 25,000 Auxiliary personnel was identified, representing more than a doubling of the approved strength. ${ }^{126}$ This resulted in a massive building programme in support of Training Command, with bases and structures designed for Toronto, Centralia, London, Clinton, Camp Borden, Aylmer, Mount Hope, Trenton and Windsor, Ontario, Montreal and St.

\footnotetext{
${ }^{125}$ Plan $\mathrm{F}$ also made mention of Air Defence Group, but failed to make specific mention of where it was to be located.

${ }^{126}$ Ibid., p. 4.
} 
Hubert, PQ, Summerside, PEI, and Greenwood, NS. ${ }^{127}$ If able to attract recruits, the RCAF was preparing to train them.

One of the differences with previous RCAF plans was the level of detail included in Plan F. Previous plans had simply identified a need for additional aircraft; the most recent version provided a year-by-year summary of expected increments, leading to an eventual total in 1954 of 344 operational aircraft for a peacetime RCAF and 639 aircraft for wartime establishment. ${ }^{128}$ Among these were 188 fighters ( 475 for wartime), 16 bombers ( 32 for wartime), 36 maritime patrol aircraft, 72 transport aircraft and 24 reconnaissance aircraft (each of these three types retained the same number of aircraft for wartime). ${ }^{129}$ Approved funding was at a level of $\$ 180$ million, ${ }^{130}$ compared to the $\$ 89$ million for Plan B and \$61.5 million for Plan E.

A separate development in 1948 attested to the increasing professionalism of the RCAF. Huntington described military professional attributes as including expertise, responsibility and "corporateness". Expertise refers to specialized knowledge and skill in a specific field based upon education and experience. Responsibility relates to the obligation of professionals to exercise their skills when required by and on behalf of society. Corporateness pertains to the organic unity and consciousness members of a group have about themselves as part of a profession..$^{131}$ Janowitz viewed the military as an interest group and placed a greater emphasis on what Huntington described as "corporateness", with Janowitz talking in terms of professional groups such as the military having developed "a sense of group identity and a system of internal

\footnotetext{
${ }^{127}$ Ibid., Construction Requirement Appendix.

${ }^{128}$ Ibid., Section B, Tab 1.

129 Ibid.

${ }^{130}$ Ibid., Section C, Tab 1.
} 
administration. Self-administration ... implies the growth of a body of ethics and standards of performance." ${ }^{, 132}$ Whether viewing the RCAF from either of these two perspectives, the 1948 creation of an air force journal, The Roundel, should be seen as an attempt to enhance professional attributes.

This monthly publication, which existed until 1965 , provided a forum for the air force to foster and develop expertise in the Huntington sense through the spread of knowledge and experience. Huntington's and Janowitz' professional attribute of "corporateness" was also promoted by this magazine, in that it helped build a sense of group identity and organic consciousness for members of the RCAF. The Roundel never achieved the sort of prestige associated with other professional journals, such as The Lancet for the British medical profession, but it did help keep the larger air force community informed of events and initiatives.

\section{Conclusion}

As 1948 ended, the RCAF could look back at its recovery from a difficult time, during which it experienced continued cutbacks and reductions, and forward to a period of expansion. For much of 1947 and 1948, the air force was short staffed, overly committed, and saddled with dated aircraft and technology. The threat posed by the Soviet Union was becoming more palpable to Canadians and the government, providing the impetus for change. Progress was being made on the implementation of the Basic Security Plan, the ramifications of which would soon be realized for the RCAF. Plan F

${ }_{132}^{131}$ Huntington, op. cit., pp. 8-10.

132 Janowitz, op. cit., pp. 6-7. 
was a watershed for the RCAF, as it was the first to provide for the development and delivery of a substantial number of modern aircraft.

The RCAF largely got away from organizing itself on the basis of geography, instead mostly working on functional lines. While Northwest Air Command remained, an Air Transport Command, Air Materiel Command, Training Command and Air Defence Group ${ }^{133}$ were established with responsibilities spanning the country. Organization along geographic principles has some merit to it, including arrangements for tasks such as search and rescue or providing assistance to civil authority, since these roles related to actions associated with a specific location. Functional organization, on the other hand, provided the means of achieving a greater degree of professional competence, economy of scale and economy of effort, since such an approach allowed expertise to be concentrated and developed to a higher degree. For instance, in relation to training, assigning this responsibility to one command allowed the others to concentrate on different areas, such as materiel management, thus avoiding the redundancy that would exist if each command did their own training. Similarly, centring air defence in a single organization provided the means of ensuring that this critical role would be approached in a unified manner. Force structure has been identified as an element in assessing military effectiveness. ${ }^{134}$ The re-organization of the RCAF along functional lines allowed military resources to be used more efficiently and increased effectiveness.

The role of Chief of the Air Staff Wilf Curtis in improving conditions for the air force cannot be discounted. In no small part, the success of the RCAF in the late 1940s

\footnotetext{
${ }^{133}$ In February 1949, Air Defence Group was re-designated as a Command. DND, DHH 193.009 (D 53) Box 4, letter from the office of the Secretary to the Chiefs of Staff Committee, file number CSC 5-11-7, dated 10 February 1949.

${ }^{134}$ Millett, Murray and Watman, op.cit, pp. 1-2.
} 
and early 1950 s may be attributed to him. He had a clear understanding of the challenges in front of him when he became Chief of the Air Staff in September 1947 and was adept at dealing with the government in order to see his vision through to completion. World events also conspired to push the RCAF to a more prominent role at the expensive of its service competitors, although under Curtis relations with the Army and the Navy appeared to have been harmonious. Curtis oversaw the development of operational specification, which led to the introduction of new technology and aircraft types into the air force. He identified the requirement for the largest number of aircraft in a peacetime RCAF up until that time and convinced the government to provide the funds necessary to begin construction. Curtis was a more effective leader than Leckie and the air force benefited from this.

Another factor in this change of circumstances is that the RCAF became increasingly proficient and professional in developing and articulating plans to achieve organizational goals. The creation of a suitable structure for planning activities was a major step forward in this. The Current Plans and Estimate Committee brought together those with wide experience and responsibilities from important organizations within air force headquarters to take part in the planning function, including air plans, organization and establishment, operational requirements and civilian oversight from the office of the Deputy Minister. It allowed a multi-disciplinary approach to planning, so that such matters as infrastructure, training and requirements could be considered concurrently. The linkage between plans and estimates was critical, since this ensured that the availability of funds was explicitly considered by planners. The absence of this relationship in the past was a main contributor to RCAF plans not receiving government 
support, as shown by the Post War Organization Committee's recommendation for 44 squadrons at a time when the government required austerity. It also provided the air force with the ability to consider how to manage overall force evolution by prioritizing the order of major developments. This organizational change strengthened RCAF planning capability and provided a sound basis for going forward. This was reflected in the quality of Plan F, the implementation of which over five years would result in a balanced, multi-purpose force, able to conduct fighter-interceptor, reconnaissance, mapping and charting, transport, tactical support and light-medium bombing roles. It was the most professional, well-reasoned and substantial example of air force postwar planning to date.

The development of operational specifications provided a concrete example of the RCAF planning for the future. The air force identified the threat and made use of new technology to develop a means of responding. The aircraft built to satisfy the specifications for the all-weather fighter and day interceptor, the CF-100 Canuck and the F-86 Sabre, had long service in the air force and were at the centre of the expansion of the postwar RCAF.

Following the creation of a suitable structure for planning activities, Air Force planners were also beginning to hit their stride. The establishment of the Air Member for Air Plans was a significant step towards improved planning. As a member of the Air Council, the Air Member for Air Plans provided a means of ensuring high-level exposure of plans by senior management. He also supported the development of plans by offering ongoing guidance to his personnel of policy decisions by the council and policy direction from the minister. 
This enhanced planning effectiveness was also influenced by improved civilmilitary relations. Claxton was a proactive minister, who managed to steer military budgets and requirements around many potential pitfalls before the Cabinet Defence Committee. As described in the previous chapter, he recognized that the services had the ability and responsibility to create plans to safeguard Canadian territory. Claxton's policy statement provided the basis for the focus on domestic security and the various threat appreciations ensured that the centre of attention was air defence. This fostered an environment favourable to the RCAF and increasingly effective planning allowed the air force to take advantage of it. The ascension of St. Laurent as Prime Minister provided the military with a more sympathetic ear than before at the Cabinet Defence Committee and the appointment of Pearson as Secretary of State for External Affairs was positive for the services. Both individuals, as internationalists, favoured Canadian participation on the world stage. This would provide opportunities for the military. St. Laurent and Pearson both perceived the Soviet Union and communism as a threat, and were receptive to the development of a Canadian response to the Cold War. The air force was well placed to take advantage of this.

Due to some conflicting behaviour, the state of professionalism within the air force progressed unevenly. The air force showed some signs of promoting organizational self-interests. It ably defined, developed and defended its future requirements in competition with the other services; yet, under the Current Plans and Estimates Committee, it also gave joint operations with the army and navy a higher priority than the acquisition of new aircraft. But despite this notional support for the other services, it did not necessarily translate into reality. In a trend that continued into the future, Table 5 
demonstrated that the air force tended to focus assets on roles that emphasized independence. For the duration of Plan F, only two squadrons were tasked to provide support to the army in the tactical bomber role and another three to maritime operations. Many of the other 27 squadrons planned for were assigned air force-related duties, including the fighter-interceptor and transport roles. As another example of contradictory actions, the Regular RCAF came close to shifting the Auxiliary into a support role because of recruitment and training problems. However, Plan F initially assigned most of the responsibility for fighter-interceptor operations to the Auxiliary, with nine reserve and only two Regular RCAF squadrons allocated to this role in 1949-50. The number of Regular RCAF squadrons increased over the life of the plan, but it never surpassed that of the Auxiliary. This inconsistency in the support provided to the other services and the Auxiliary implies that the postwar air force was still struggling to develop the sense of group identity that Janowitz associated with "corporateness".

Notwithstanding these problems, the RCAF continued to effectively promote organizational self-interests. Air Commodore Dunlap's advocacy before the Inter-service Planning Group for a greater air force role, which included a call for "a re-adjustment of the allocation of manpower with a substantial increase in favour of the Royal Canadian Air Force", ${ }^{135}$ demonstrated this kind of behaviour. Similarly, the scope of Plan F and Curtis' intention to eventually build a fighter force of up to 556 aircraft showed an air force desire to compete for a good share of government expenditures on defence.

Compared to the previous postwar years, 1947-1948 saw much improvement to RCAF conditions. The air force was learning from past experiences and becoming more

\footnotetext{
${ }^{135}$ LAC, RG 24, Vol 6174, file HQ 19-7-79, Vol 1, Letter from Air Commodore C.R. Dunlap to Chairman, Interservice Planning Group, dated 1 December 1946.
} 
adept at preparing plans for the government. More forethought was exhibited in making the case for the air force. Plan F represented an evolution in the strategic planning abilities of the air force. With it, the RCAF became better at defining and articulating requirements, which facilitated a more comprehensive approach to planning. The phased introduction of equipment over a number of years helped make the financial demands on the government more palatable. Plan F provided the initial basis for the subsequent growth of the air force, and the eventual form and function of the RCAF as a Cold War force. Its development was a manifestation of an improving air force planning capability. 


\section{CHAPTER FIVE:}

\section{GAINING INFLUENCE:}

\section{THE RISE OF THE RCAF, 1949}

As the 1940s drew to a close, initial steps had been taken to prepare the air force for the future, including the creation of a series of operational specifications for modern aircraft designed to respond to the evolving threat and the requirement for a secure production line for new fighter aircraft was articulated. The approval of the Basic Security Plan, which was focused on providing an air defence plan for North American, gave the employment framework for these interceptors. The combination of the Basic Security Plan and the development of Plan F demonstrated advances in the air force's ability to plan, as did the establishment of a dedicated planning organization under its own senior Air Member.

This chapter will examine the continued evolution of planning within the RCAF. It will begin with an exploration of how the RCAF sought to develop an air defence plan in order to satisfy many of the Basic Security Plan requirements. It will look at how periodic intelligence appreciations changed air force plans and whether such changes could reasonably be expected to be effective against the changing threat. There will also be an examination of how the RCAF planned to acquire the new interceptor capability, including a review of how and why some options for acquiring this capability were rejected. In addition, the impact of a new defensive alliance will be examined. This created circumstances very favourable for the expansion of the RCAF and facilitated a greater defence role for the air force. 
Air Defence and Related Plans

A significant level of the RCAF's effort during 1949 went towards implementing Plan F and the air portion of the Basic Security Plan. On 24 January, the Director of Air Plans (Peace) completed an air defence plan, which included an assessment that, in the event of hostilities, the Soviet Union would likely launch diversionary attacks against North America from Siberia, and Northern and Western Europe. Since the Soviets had no base of operations in western Europe at that time, this document presumed that some of these potential attacks would follow a series of land-based battles leading to the Soviet takeover of such western democracies as France and the United Kingdom. To safeguard against such attacks in western Europe, the air defence plan advocated deploying an air expeditionary force overseas in the United Kingdom. Such an overseas deployment would have resulted in a measure of risk for North America, since any resources sent across the Atlantic would not be available for homeland defence, but this was considered an acceptable risk. ${ }^{1}$

The RCAF was well in front of its political leadership. No discussions had been held with the Minister of National Defence or with the Cabinet Defence Committee about sending the RCAF to defend the United Kingdom or other areas of western Europe. On its own initiative, the RCAF was beginning to consider the possibility of sending air force assets to help protect the security of another nation, which it had never done before in peacetime. It was the responsibility of the RCAF to produce contingency plans as part of its professional responsibilities NATO provided justification for this kind of activity. But the air force had to exercise care not to intrude into the political arena or to pre-empt the 
government's prerogative to decide policy matters, such as whether to deploy squadrons on foreign soil.

Other components of this January 1949 air defence plan were more focused on directly protecting Canadian sovereignty. Initial plans intended to protect Canada's industrial corridor stretching between Quebec City, Montreal, Ottawa, Toronto and the Niagara area through the establishment of fighter bases in St. Hubert and Bagotville, Quebec and Ottawa and Downsview, Ontario. However, planners began to see the advantages of taking a defence in depth approach, whereby defensive forces would be deployed further north, with the intent of engaging a potential aggressor well away from Canadian industrial production centres. The possibility of assistance from the United States to protect Canadian territory closer to the US-Canada border was discussed but rejected because of the political unacceptability of having American forces deployed on Canadian territory, the potential for the US not being able to provide such coverage and the necessity for self-reliance on matters of defence. ${ }^{2}$

As another consideration of how fighter forces should be deployed, the Cabinet Defence Committee had announced that the RCAF would be located in the Bagotville and Mont Joli, Quebec and Chatham, New Brunswick areas. The air force had not been involved in these announcements and was still trying to identify the best sites for interceptor bases. To complicate matters further, the Minister of National Defence had publicly stated that fighter squadrons:

are to be formed as rapidly as possible and are to be shown to the public. It follows, then, that if this is done, a large percentage of

\footnotetext{
${ }^{1}$ DND, DHH 96/24, file 096-105, vol 6, TS 78-7-2 (DAPP), dated 24 January 1949, p.1.

${ }^{2}$ Ibid.
} 
our squadrons should be located near the larger centres of industry and population. ${ }^{3}$

In reviewing the suitability of these and other air bases, RCAF planners found a variety of problems at potential sites. At Chatham and Ottawa, the runways were too short to accommodate jet fighters, thereby requiring runway extension before becoming suitable. Other sites, including St. Hubert, Downsview and Windsor, were without accommodations. Mont Joli, Bagotville and Borden had both runway and accommodation shortfalls. ${ }^{4}$ In fact, deficiencies of this sort could be applied to any airfield within Canada, so the deployment of fighter squadrons had to be accompanied by a building program of some sort, which caused delays and incurred infrastructure expenses. $^{5}$

An additional factor to be considered in association with an air defence system was communications. The air defence plan proposal identified the Windsor-Montreal corridor as the only area with extensive communication infrastructure, and even that could handle only an elementary air defence communications system. The amount of communications traffic that would have to be passed back and forth in support of an air defence system required massive upgrades to the existing infrastructure. This led to the assessment that communications requirements could cause a three or four year delay in the fielding of an effective air defence systems. ${ }^{6}$

In discussing what the appropriate size for an air base was, planners believed that bases should be large enough to service at least two 12 aircraft squadrons during

\footnotetext{
${ }^{3}$ Ibid.

${ }^{4}$ Ibid., p. 2.

${ }_{6}^{5}$ Ibid., p. 3.

${ }^{6}$ Ibid.
} 
peacetime and be capable of accommodating wartime expansion. Moreover, the military principle of concentration of forces ${ }^{7}$ indicated that the air force should situate squadrons in such a manner that invading forces would be overwhelmed at a place selected by the RCAF. This approach precluded the scattering of aircraft in small groups across the country; otherwise the RCAF ran the risk of being overrun easily by a larger force. Another military principle, economy of effort, suggested that there was an advantage to clustering squadrons together. This would allow support personnel and facilities to be shared by multiple squadrons. Yet, to a large extent, these factors were not decisive enough to influence site selection. The RCAF was being asked to protect five centres (Quebec City, Montreal, Ottawa, Toronto and the Niagara region) and it was establishing only nine squadrons. Consequently, force concentration would be limited to two squadrons at most at any one location. ${ }^{8}$

The timetable for establishing these squadrons (two in 1949-50, another two in 1950-51, three in 1951-1953 and the final two in 1953-54) allowed time to train personnel and to obtain the equipment. There were still problems to overcome for the implementation of the air defence plan, since construction of accommodations and communications support requirements were expected to lag behind this schedule. ${ }^{9}$ In order to address some of the concerns about the need for defence in depth, the plan also recommended that emergency fields be prepared north of the population centres in areas

\footnotetext{
${ }^{7}$ The principles of war are tenets that the military uses to focus on the successful prosecution of military force. The Canadian principles of war are based on the British model, which includes selection and maintenance of the aim, concentration of force, effort of economy, maintenance of moral, offensive action, flexibility, cooperation, security, surprise and sustainability. The first articulation of these is attributed to Carl Von Clausewitz, a Prussian military officer who wrote the influential On War in the early $19^{\text {th }}$ century. For more details, see Carl Von Clauswitz, On War, translated by Michael Howard, (Ewing, New Jersey: Princeton University Press, 1989).

${ }^{8}$ DND, DHH 96/24, file 096-105, vol 6, TS 78-7-2 (DAPP), dated 24 January 1949, p. 3.

${ }^{9}$ Ibid.
} 
like Senneterre, Quebec and North Bay and Kapuskasing, Ontario. ${ }^{10}$ The construction of these would also affect when the air defence plan could become fully operational.

The question of whether to prepare for immediate area defence or defence in depth through the deployment of squadrons north of population and industrial centres remained contentious for air force leaders. At a meeting of the senior Air Members on 27 January 1949, two options were briefed. The first of these, prepared by the Air Plans Division and referred to as Plan I, was based on the previously described air defence plan. It advocated co-locating fighter squadrons with the population and industrial centres. Under this approach, one squadron would be deployed to Chatham, and two each to Bagotville and St Hubert, Quebec, and Borden and Uplands (Ottawa), Ontario. A number of other air fields would be developed for emergency wartime use further to the north.

Plan II, which was prepared by No. 1 Air Defence Group, promoted an approach conducive to operational efficiency. It was also more supportive of the goals of the Basic Security Plan., through the priority development of an air defence system that focused on the defensive measures required in an emergency. This plan proposed building first in the north, locating three squadrons in both Senneterre and La Tuque, Quebec, one squadron each for Mont Joli and Bagotville, Quebec and the final squadron in Chatham, New Brunswick. The Commander of No. 1 Air Defence Group, Group Captain W.R. MacBrien, argued that this scheme would provide better fighter and radar coverage and noted that it was supported by the Commanding General of USAF Air Defence

\footnotetext{
${ }^{10}$ Ibid., p. 5.
} 
Command. ${ }^{11}$ The idea behind this plan was that the pre-positioning of the squadrons in the north would allow earlier interception of an attack, before population and industrial centres could be reached.

One of the main advantages of Plan II was that it was scheduled for completion during 1954. Plan I would take until 1956. However, those in favour of Plan I argued that situating air bases near population centres would be more advantageous because it would engender more public support and publicity for the RCAF. This would be accomplished as the result of the increased visibility to the general population achieved during routine flying operation. Situating bases near cities also would be better for RCAF members and their families due to the hardships associated with isolated postings. Another advantage of Plan I was that it was easier to implement because labour would be readily available from nearby communities. The isolated sites proposed by Plan II would encounter problems finding a sufficiently large workforce for construction and ongoing support once the base became operational. Plan I was also seen as beneficial to Auxiliary squadrons, since their training would be faster and better due to ready access to and support from the Regular force. ${ }^{12}$

MacBrien countered by focusing on the operational benefits of his plan.

Specifically, he argued that his disposition of squadrons would allow the greatest number of fighters to be brought to bear on an attacking Soviet force, which resulted in better protection for the vital areas of the country. Plan II also avoided spreading forces too thinly, which meant that resources would be more efficiently used. He believed that locating defence forces with the locations being targeted would be ineffective compared

\footnotetext{
${ }^{11}$ DND, DHH, Raymont Papers, 73/1223, File 1820, Minutes of the $65^{\text {th }}$ Meeting of the Air Members, held at 1100 hours and 1600 hours, 27 January 1949, pp. 1-2.
} 
to his defence in depth approach, ${ }^{13}$ the merit of defence of which had been demonstrated during the Second World War.

A middle ground between these two approaches was suggested by Air Vice Marshal Slemon. He indicated that, if hostilities broke out before MacBrien's defence in depth approach was fully established, there would be no choice but to co-locate air forces with the population and industrial centres. But in order to achieve the long-range defence plan articulated in the Basic Security Plan, he observed that defensive measures near such locations had to be kept to a minimum. Slemon argued that while study had confirmed the efficacy of Plan II, Plan I had not been subjected to similar concerted scrutiny. Therefore, it was difficult to definitively say that Plan II was more effective than Plan I. Slemon concluded with the observation that the RCAF's responsibility was to provide the government with recommendations leading to the most effective air defence for Canada and not be influenced by such considerations as publicity and public relations. After receiving this advice, it was within the purview of the government to ask for modifications based upon political considerations, but that the air force should not anticipate these. $^{14}$

These comments by Slemon were the beginning of a compromise between the two plans. Following a three-hour break in the meeting of the Air Members, during which there undoubtedly were some informal discussions, the meeting was reconvened and a third approach was articulated. Air Vice Marshal C.R. Dunlap, Air Member for Air Plans, indicated that, while there were similarities between the two plans discussed, neither fully addressed requirements. There seemed to be agreement on establishing a

\footnotetext{
${ }^{12}$ Ibid., p. 3.

${ }^{13}$ Ibid.
} 
chain of air bases and radar sites essentially along the line proposed by Plan II, stretching from Chatham through Mont Joli, Bagotville, La Tuque, Greening, Senneterre to Kapuskasing by 1956. In Dunlap's view, the best way forward was to task a team of planners with combining the best features of Plans I and II, allocating of squadrons during peacetime and wartime as shown at Table 6 . The results of this effort could then be reviewed by the Air Members.

Table 6: Proposed Fighter Squadron and Airfield Disposition (1949) ${ }^{15}$

\begin{tabular}{|c|c|c|}
\hline AIRFIELD & $\begin{array}{c}\text { PEACETIME } \\
\text { SQUADRONS }\end{array}$ & WARTIME SQUADRONS \\
\hline Chatham & 1 & 1 \\
\hline Bagotville & 2 & 2 \\
\hline La Tuque & 1 & 3 \\
\hline Senneterre & 1 & 3 \\
\hline Montreal & 1 & - \\
\hline Ottawa & 1 & - \\
\hline Borden & 1 & - \\
\hline
\end{tabular}

Slemon accepted this compromise on the condition that the development of the southern air bases did not delay the work on the more northerly sites. In the event that construction timelines could not be met, he preferred focusing first on the north. The Chief of the Air Staff, Air Marshal Curtis, weighed in on the discussion, pointing out that during wartime the public would be concerned with the efficiency of the defence scheme. Public criticism directed at the RCAF would be directly influenced by the number of attacking aircraft that got through. Therefore, the RCAF had to select and forward to government for approval the best possible air defence plan. Curtis also acknowledged

\footnotetext{
${ }^{14}$ Ibid., p. 4.

${ }^{15}$ Ibid., p. 5.
} 
that, for political reasons, it was not feasible to put three squadrons in an isolated location during peacetime. It was better to put only one squadron each in such places as Senneterre or La Tuque and to position other squadrons in Borden and Uplands (Ottawa). ${ }^{16}$

The Air Members discussed the merits of the compromise put forward by Dunlap and agreed to support it. Based on a combination of Plans I and II, planners were directed to consider where the Auxiliary squadrons should be located to best support operations. Another factor to be considered in the revised plan was physical infrastructure. RCAF leadership wanted the ability to concentrate up to three squadrons at select northern location during times of emergency. In peacetime, the intent was to place only one squadron in these more isolated air bases. ${ }^{17}$

While awaiting Dunlap's return with the revised air defence plan proposal, a series of noteworthy issues were dealt with. In the first place, in early February, concerns related to the Auxiliary came to the forefront again. In addition to difficulty in deciding where to place the next Auxiliary squadron, with Windsor, Oshawa, Ottawa and Sudbury receiving varying degrees of consideration without resolution, the question of their functional control was examined. Noting that Plan F had called for Auxiliary squadrons to transfer from Training Command to No. 1 Air Defence Group on 1 April 1949, the Air Member for Air Plans considered this course of action premature due to continuing problems with staffing, equipping and training the Auxiliary force. This led Dunlap to recommend that it stay under Training Command for a while longer. Senior RCAF leadership concurred with this suggestion, except in regards to the two Montreal

\footnotetext{
${ }^{16}$ Ibid., p. 6.

${ }^{17}$ Ibid.
} 
Auxiliary squadrons, which operated out of the St. Hubert airfield. St. Hubert also hosted the Regular RCAF Operational Training Unit and a regular fighter squadron under the functional control of No. 1 Air Defence Group, and because the Auxiliary and Regular RCAF squadrons and the training unit made use of common services and infrastructure, there was concern about potential difficulties associated with co-located units coming under the functional control of different commanders. Therefore, it was decided that, once No. 1 Air Defence Group was ready, it would assume responsibility for the two Montreal area Auxiliary squadrons from Training Command. ${ }^{18}$

At the RCAF Auxiliary Conference during May of the previous year, Slemon had convinced the air force leadership to commit more training resources to the Auxiliary force and Air Vice Marshal Plant had recommended adjusting the Auxiliary role from first line defence to one of augmenting the RCAF in times of emergency. Since then, it had become increasingly evident that efforts to make the Auxiliary RCAF more selfsufficient had been unsuccessful. Soon after the decision to delay the transfer for the Auxiliary Squadrons from Training Command to the Air Defence Group, the apparently inevitable occurred. RCAF leadership decided to amend the role of the Auxiliary to that of providing "a first line reserve of fully organized, manned and equipped squadrons trained to a standard which will permit them to be mobilized" 90 days after their call-up in support of the Regular RCAF. ${ }^{19}$ Auxiliary squadrons were no longer being counted upon to serve an operational role in the day-to-day air defence of Canada. This represented a significant reduction in their role from the early postwar period, when they

\footnotetext{
${ }^{18}$ DND, DHH, Raymont Papers, 73/1223, File 1820, Minutes of the $66^{\text {th }}$ Meeting of the Air Members, held at 1500 hours, 2 February 1949 , p. 4.

${ }^{19}$ DND, DHH, Raymont Papers, 73/1223, File 1820, Minutes of the $72^{\text {nd }}$ Meeting of the Air Members, held at 1430 hours, 23 March 1949, pp. 2-3.
} 
were entrusted with providing most of the defence of Canadian airspace. A related decision by RCAF leadership at this time was to task the Auxiliary force with training personnel to a standard that would allow them to be mobilized quickly to augment the Regular RCAF during emergencies. This too was a decrease in the expectations for the Auxiliary. To achieve these roles, the strength of the RCAF Auxiliary was set at around 25,000 , with this total changing as required to reflect the size of the Regular Force and the ability of the RCAF to provide training assistance. ${ }^{20}$

The Joint Planning Committee released a plan detailing requirements for the command and control of air defence within Canada. ${ }^{21}$ This document identified the requirement for an integrated system, including a fully developed means of controlling aircraft and a reporting system for the entire country. The air defensive coverage area extended to the approaches to Canada. Control of Canadian air defence elements was achieved through a purpose-built reporting system. It was designed to facilitate the early warning and identification of aircraft within an area, as well as providing the information needed for interceptors and anti-aircraft resources. ${ }^{22}$ Another essential feature was a means to effectively coordinate overall air defence, including anti-aircraft weapons and aircraft, deceptive measures and radio counter-measures. The system was also intended to support an air raid warning system. The air force was responsible for developing this system, with the cooperation and participation of the other services. ${ }^{23}$

\footnotetext{
${ }^{20}$ Ibid.

${ }^{21}$ DND, DHH, 193.009 (D 53), Box 4, JPC 17-15, entitled "Command and Control of the Air Defence of Canada", dated 3 February 1949, from the Joint Planning Committee to the Chiefs of Staff Committee, attached to letter CSC 5-11-7, entitled "Command and Control of the Air Defence of Canada", dated 10 February 1949, from J.D.B. Smith, Brigadier, Secretary, Chiefs of Staff Committee, to CGS, CAS, CNS, and CDRB.

${ }^{22}$ Ibid., p. 1.

${ }^{23}$ Ibid., pp. 2-3.
} 
To provide overall direction to air defence, it was proposed that Air Defence

Headquarters, supported by a series of subordinate headquarters, exercise command over Canadian air defence. The Commander of Air Defence Command, who had to be an air force officer, would be responsible directly to the Chiefs of Staff Committee, and would

\section{Figure 6: Air Defence Command Plan ${ }^{24}$}

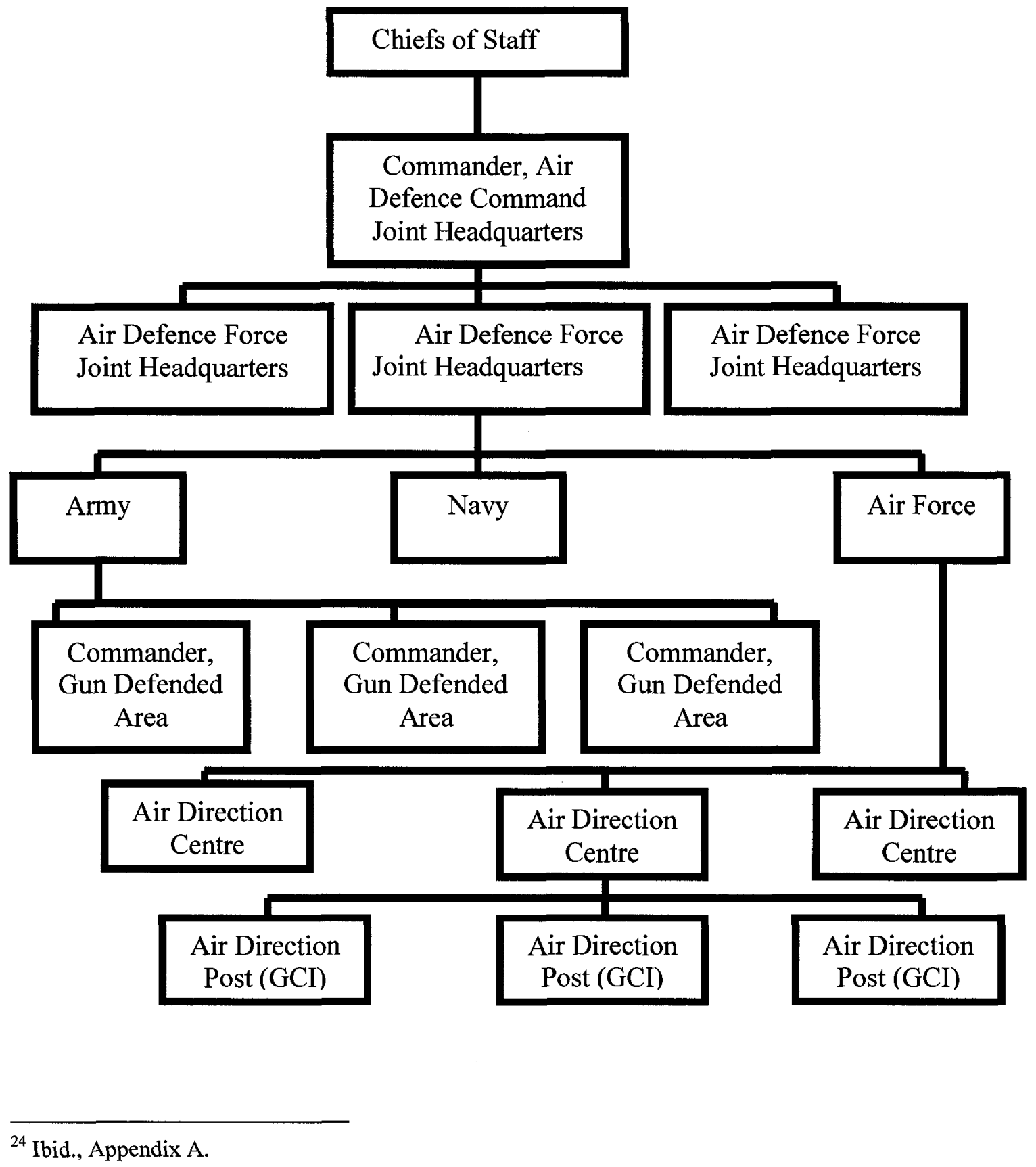


be provided with an integrated staff with representatives from all participating agencies. Under this Commander would be air defence groups, each with its own Commander and integrated headquarters, who would be responsible for air defence within his designated area. Figure 6 provides an overview of this command structure.

The original intent was to eventually exercise the control of interceptors and antiaircraft forces from a joint operations room, but the Joint Planning Committee acknowledged in 1949 that communication capabilities and geography limited the ability to achieve this. Until such time as a more integrated system could be built, tactical control of these two elements of the air defence forces would be exercised separately at RCAF and Anti-Aircraft Operation Rooms. To safeguard against friendly fire on Canadian interceptors from anti-aircraft forces as the result of inadequate coordination caused by limitations of communication technology, the Joint Planning Committee suggested that a number of no-fly zones be created for the RCAF and that Canadian aircraft be restricted to defined routes and heights in select areas. ${ }^{25}$

In addition to the command structure, the means of controlling components of the air defence system had to be worked out. Most of the elements of the air defence system were under the direction of the Commander, Air Defence Command. An exception was anti-aircraft defence, which had its own subordinate Commander. The anti-aircraft defence Commander, from the Canadian Army, was informed by the air defence reporting system and was tasked with supporting the Commander, Air Defence Command. Control of interceptors would be exercised by Air Defence Force Joint

\footnotetext{
${ }^{25}$ Ibid., p. 3.
} 
Headquarters and directed by air controllers. ${ }^{26}$ Figure 7 provides an overview of the air defence control system.

\section{Figure 7: Air Defence Control Plan ${ }^{27}$}

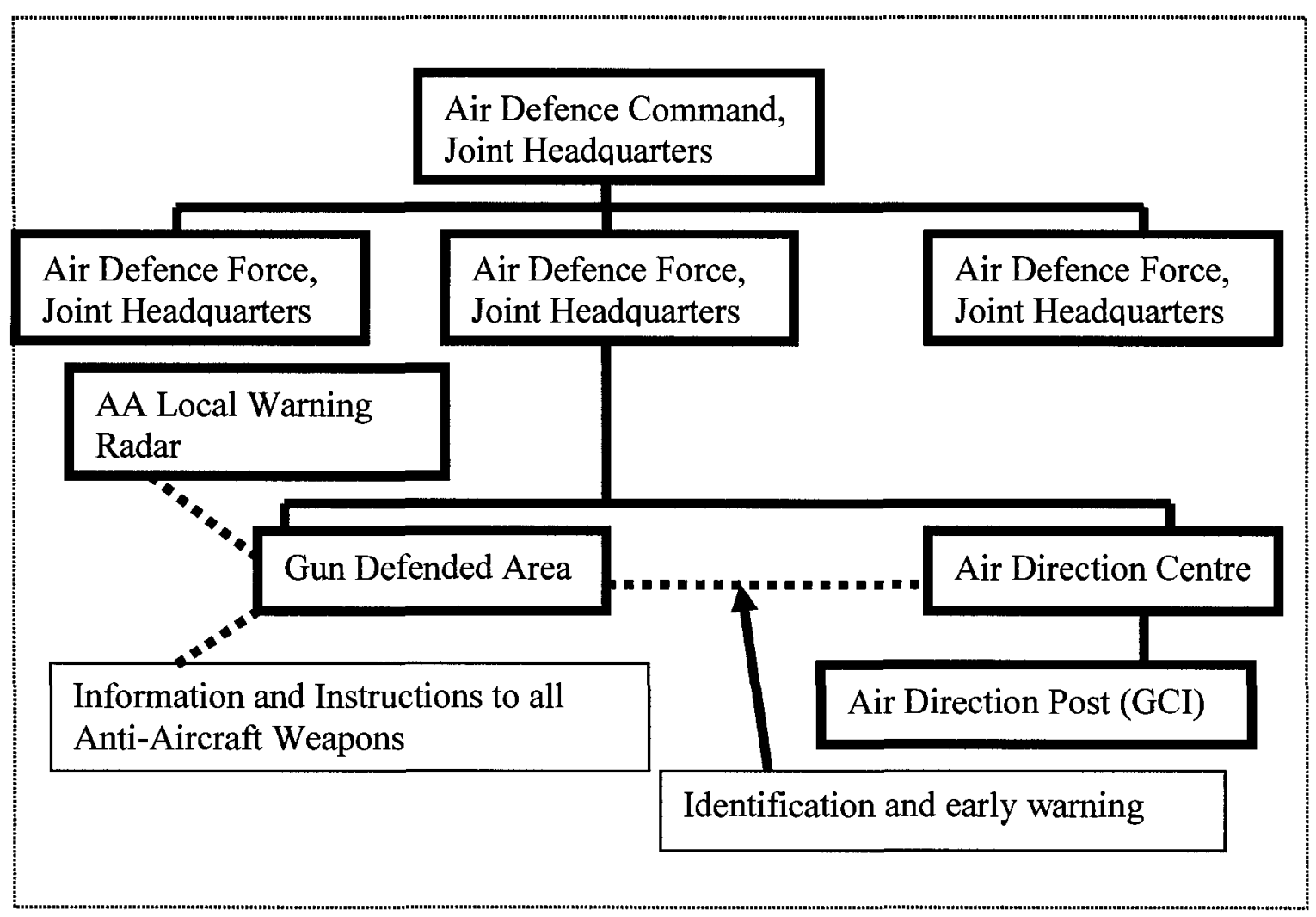

This plan for the command and control of air defence forces had its merits, including the integration of the ground and air elements under one Commander, support by a control system that was intended to facilitate an effective allocation of resources and a means for the information sharing required to allow the different components to do their respective jobs. The shortfall in this plan was in the implementation, as the Canadian Army did not commit many forces to the domestic anti-aircraft role, and the army and air

\footnotetext{
${ }^{26}$ Ibid., pp. 3-4.

${ }^{27}$ Ibid., Appendix B.
} 
forces did not dedicate much effort to making this integrated system work. This lack of cooperation very well may be attributable to inter-service rivalry. The army often sought roles that highlighted its value and independence, such as the land forces deployed as part of the Korean Conflict, and tended to provide little support for tasks in which it was subordinate to another service. The RCAF behaved similarly, actively supporting the air defence mandate but paying relatively little attention to the close air support role. Nevertheless, with the exception of the army components of the Air Defence Command and Control Plan, this system was put into place and provided the means for overseeing the security of Canadian airspace.

On 7 February 1949, the Joint Planning Committee reported to the Chiefs of Staff Committee concerning the state of port defences on the Pacific coast. ${ }^{28}$ Air force components of this plan identified RCAF responsibilities as including force concentration in the Vancouver and Victoria area, organizing the civilian population to provide warnings of incoming attacks, activation of air force reserves, and collocation of air force control operations to a joint headquarters. ${ }^{29}$ This report identified major deficiencies in the resources available for such a mission, with shortfalls noted for each of the three services. In particular, the RCAF allotted only one Auxiliary fighter squadron and one search and rescue flight to protect the entire west coast. The air force also had little radar coverage throughout British Columbia at this time, although there was a commitment to

\footnotetext{
${ }^{28}$ DND, DHH, 193-009 (D 53), Box 4, letter CSC 5-11-6, entitled "Defence of Ports - Pacific Coast' dated 7 February 1949, from J.D. B. Smith, Brigadier, Secretary, Chiefs of Staff Committee, to CGS, CAS, CGS and CDRB, attached to extract from Minutes of the $441^{\text {st }}$ Meeting of the Chiefs of Staff Committee Held 23 February 1949.

${ }^{29}$ Ibid., enclosure JPC 19-5, Joint Planning Committee Report "Defence of Ports - Pacific Coast", dated 3 February 1947, Appendix A, p. 5.
} 
send additional radar warning capacity in time of emergency. ${ }^{30}$ While the navy identified more substantive resources for west coast defence, the army was as frugal with its west coast resources as the RCAF. Neither service placed much importance on the defence of British Columbia. The industrial capacity of Canada and the United States in the eastern part of the continent was given higher priority for protection from the air threat in order to maintain military forces. The issue of how much effort to put into protecting secondary population areas was resolved when the Chief of the Air Staff directed that centres like Vancouver and Halifax were to be provided coverage by Regular RCAF fighter squadrons and radar units as part of wartime defensive measures. ${ }^{31}$

Another topic of interest to RCAF leadership was a review of the merits of the De Havilland Vampire compared to other available aircraft, which was completed in midFebruary 1949. A factor in conducting this assessment pertained to a requirement to standardize on British or American patterned equipment. This was influenced by which ally Canada would most likely fight beside, since standardization would facilitate interoperability and help ensure the continued availability of spare parts. By pairing with a major ally which would be purchasing the same aircraft as Canada, economy of scale could be achieved, with large sales helping to reduce per aircraft cost. Since the Basic Security Plan tied Canada's defensive efforts to the United States, the possibility of future air force aircraft being based on British design was remote. British manufacturing used different standards, procedures and techniques from Canadian industry, so use of a British design would necessitate extensive re-tooling. Therefore, just as the air force had

\footnotetext{
${ }^{30}$ Ibid., enclosure JPC 19-5, Joint Planning Committee Report "Defence of Ports - Pacific Coast", dated 3 February 1947, Annex 1 to Appendix B, p. 2.

${ }^{31}$ DND, DHH, Raymont Papers, 73/1223, File 1820, Minutes of the $74^{\text {th }}$ Meeting of the Air Members, held at 1430 hours, $13^{\text {th }}$ April 1949, p. 2.
} 
decided in 1944 and 1947, it was clear that Canada would be best served by purchasing American equipment. The RCAF also astutely concluded that it would be politically and economically more acceptable to ensure that whatever aircraft was selected for service be manufactured, as much as possible, within Canada. ${ }^{32}$ The American government and industries would be approached about the viability of locating aircraft manufacturing north of the border as part of future negotiations.

With the CF-100 Canuck scheduled to fulfil the role of the all-weather fighter (Operational Requirement No. OR/4), the most pressing need for Canada was for a jet day interceptor (Operational Requirement No. OR/1). There had been discussions with the Cabinet Defence Committee on this issue in October $1948^{33}$, but no real action had been taken. Features sought for a new day interceptor included that it be available for service in the 1949-51 period, that it be advanced enough to serve as a first-line aircraft for at least five years, and that it be produced in the United States. This reduced the eligible field to the United States Navy's Grumman F9F Panther or the USAF's North American F86A Sabre. In view of the propensity for the RCAF to work with its air force counterpart, the Sabre quickly became the focus of Canada's interest as a day fighter. ${ }^{34}$ This was the same aircraft endorsed previously by the Cabinet.

To ensure that the air force was not trading in the Vampire for a lesser product, a comparative analysis was conducted between it and the Sabre. The Vampire required less take-off distance, had a higher operational ceiling and better turning radius, and had

\footnotetext{
${ }^{32}$ DND, DHH, Raymont Papers, 73/1223, File 1820, Minutes of the $67^{\text {th }}$ Meeting of the Air Members, held at 1500 hours, Monday, 14 February 1949, pp. 4-5.

${ }^{33}$ LAC, RG 2, Vol 2748, Minutes of the $51^{\text {st }}$ Meeting of the Cabinet Defence Committee, dated 30 October 1948 , pp. 5-6.

${ }^{34}$ DND, DHH, Raymont Papers, 73/1223, File 1820, Minutes of the $67^{\text {th }}$ Meeting of the Air Members, held at 1500 hours, Monday, 14 February 1949, p. 6.
} 
an engine less prone to icing. The Sabre had the advantage in regards to range and speed, which directly related to its suitability to defend North American airspace. It was already in production and was available within months compared to the two-three years for more current versions of the Vampire. The Sabre was also considered more durable and satisfied the requirement for interoperability, so long as the United States was Canada's primary defence ally. When comparing armament, the Vampire had four $20 \mathrm{~mm}$ cannons with 150 rounds each and two $1000 \mathrm{lb}$ bombs or eight $60 \mathrm{lb}$ rockets. The Sabre had six .5 " guns with 300 rounds each and a variety of bombs ranging from $100 \mathrm{lb}$ up to two $1000 \mathrm{lb}$ bombs. In lieu of $60 \mathrm{lb}$ rockets, the Sabre could be fitted with up to 165 " high velocity aircraft rockets. ${ }^{35}$ The North American Sabre was manifestly a better option than the De Havilland Vampire.

Based upon these considerations, the North American Sabre was readily selected as the best day fighter for the RCAF and as a replacement for the existing Vampires. Consequently, the air force requested support from the government to procure 56 Sabres immediately and to support the purchase of another 200 to be manufactured in Canada. ${ }^{36}$ This satisfied the requirement identified to the Cabinet Defence Committee the previous October for 256 day fighters. Cabinet was also asked to support the manufacture of the CF 100 Canuck in sufficient quantity to satisfy the all-weather fighter requirement. Details on government deliberations in this area will be described later.

In mid-March 1949, Dunlap was still having difficulty in deciding what approach to take when combining the two Air Defence Plans briefed in January. In discussion with the other Air Members, Dunlap restated that an effective air defence system was the sole

\footnotetext{
${ }^{35}$ Ibid., p. 8.

${ }^{36}$ Ibid.
} 
practicable method to defend Canada and the United States from a potential attacker. Fighter-interceptors, a radar chain to provide early warning, and Ground Control Interception (GCI) facilities, which directed interceptors to a potential target identified by radar, all had to be built. Given the likelihood of such an aggressor developing atomic weapons, this made the requirement for a comprehensive air defence system all the more important. The central problem for Dunlap, and by extension the rest of the RCAF, was that the building of a complete system required a significant commitment of manpower, materials and funds over multiple years. The air force's practice to date was to approach the government annually to seek the funding to address some outstanding component of the air defence system, without assurance that the unfunded portions of the plan would later receive support. Incremental increases to the RCAF budget resulted, as the government preferred to consider and approve the development of air defence system on a piece-by-piece basis. In view of the pace of funding being provided by the government, the Air Member for Air Plans estimated that it would take fully 20 years to complete the air defence system. ${ }^{37}$ If the RCAF was to be able protect Canadian airspace from the Soviet threat, this had to change.

Instead of accepting this state of affairs, Dunlap forcefully advocated the creation of an all-inclusive air defence plan, detailing the full manpower, material and costs implications of fielding the system between 1949 and 1956. Such a plan would include a year-by-year breakdown of cost, so that the government could better forecast what funding may be required for different phases of the plan. By taking a longer view, the air force would be able to plan more comprehensively and improve the integration of various

${ }^{37}$ DND, DHH, Raymont Papers, 73/1223, File 1820, Minutes of the $70^{\text {th }}$ Meeting of the Air Members, held at 1500 hours, $14^{\text {th }}$ March 1949, p. 2. 
plan components. He also believed that this approach would make it much easier to obtain support for an enlarged RCAF and quicker overall system development. ${ }^{38}$

Air Marshal Wilf Curtis understood the risks and benefits of taking such an approach with the government. He believed that he would have difficulty finding support, especially if presented in a manner similar to that used for the annual implementation program, which tended to provide limited details beyond costs. It was important for the political decision-makers to have sufficient detail to understand what was being sought, why and what it cost. Despite these concerns, he believed that there was merit in developing and costing a comprehensive overall plan to provide for the air defence of Canadian vital points. Initially this kind of plan would be for RCAF consumption only. After working with and improving it, the plan could be presented at an appropriate time to Minister of National Defence Claxton. Subsequently, as conditions warranted, it could be forwarded to the Cabinet Defence Committee or to the entire Cabinet in a bid to obtain government support. Curtis believed that this kind of phased approach had a chance of being successful. ${ }^{39}$

Curtis also expressed a desire to see the RCAF build up to a strength of 32 squadrons as quickly as possible and expressed concern that Plan $\mathrm{F}$ as being implemented was not meeting requirements. After Curtis proposed that this problem be taken to Claxton, Air Vice Marshal A. L. James, Air Member for Technical Services, astutely argued that such a measure should be deferred until a clearer understanding of the implications of the forthcoming North Atlantic Treaty were known. This new alliance would likely influence the composition and forces available for North American Air

\footnotetext{
${ }^{38}$ Ibid.

${ }^{39}$ Ibid.
} 
Defence, so it would be best to take this into consideration before approaching the political level. In addition to this, James suggested that the RCAF seek authority from government to submit budgets covering multiple years. The method used at that time consisted of submitting annual budgets to solicit support the various air force plans (Plan B, Plan E and, at that time, Plan F). James believed that this approach resulted in a ten percent increase in costs over what could be achieved through the development of a program that covered multiple years, perhaps four or five. ${ }^{40}$ He was quite correct in pointing out that such an approach was a better business practice, since better and more secure long-term scheduling, economies of scale, and improved synergy between program elements were well-known means of achieving savings.

Dunlap also contended that revisions to the air defence plan had to consider means of reducing costs, since current intentions meant that the overall expenditures would be very high. He proposed the elimination of the outer early warning radar chain along the Labrador coast. Should this recommendation be embraced, it meant that a radar chain further inland, the transcontinental line, would have to serve the role of early warning. In turn, this meant that interceptor bases would have to be located further south in order to be able to respond to the warning provided. By moving the airbases further south, additional savings might be realized through the selection of existing aerodromes vice having to build them in more isolated locals to the north. ${ }^{41}$

A second cost savings recommendation by Dunlap concerned the deletion of the requirement for trailer aircraft, which involved shadowing aircraft tracking intruders while awaiting the arrival of interceptors. The trailer aircraft would then help direct and

\footnotetext{
${ }^{40}$ Ibid., p. 3.

41 Ibid.
} 
coordinate the interceptors in their fight with the enemy. Air Vice Marshal Slemon provided support for this cutback, indicating that operational analysis of the concept had shown that it was flawed. The time required for trailer aircraft to reach an operational height, from which an intruder could be located and followed, along with the small number of aircraft intended for this role, rendered the entire idea operationally ineffective. $^{42}$

Debate by the senior RCAF staff identified other possible areas of savings, including the idea of using mobile early warning and ground control interception units along the transcontinental line in lieu of constructing permanent installations. This approach would have the advantage of facilitating the re-location of units elsewhere in Canada or even overseas, as requirements dictated. The possibility of building airstrips only for every second base was discussed, with the intention of achieving savings by concentrating infrastructure in half the locations and constructing just airstrips for the other sites, which would be used on a limited basis. ${ }^{43}$ In view of the number of recommendations for savings coming forward, Slemon made the sensible proposal that the air defence plan, which was widely acknowledged by air force leaders as too expensive, be reviewed once again with a view of deleting everything not considered operationally essential. As part of this exercise, he advocated the preparation of two versions of the air defence plan. One would be limited in scope and be reasonably expected to receive government support, whereas the second version would detail the complete requirements for the air defence system ultimately sought by the air force. ${ }^{44}$

\footnotetext{
${ }^{42}$ Ibid., pp. 3-4.

${ }^{43}$ Ibid., p. 4.

${ }^{44}$ Ibid.
} 
Subsequently, the development of a long range plan was directed, which would be used to articulate internally the eventual size, composition and scope of the RCAF. ${ }^{45}$

Following discussion, the Air Member for Air Plans was directed to provide an air defence plan that covered a four or five year program. It was to consider a range of options, including the delay of the introduction of the Labrador-based early warning sites and deletion of trailer aircraft. A comparison of costs for permanent and mobile ground control interceptor and radar sites was to be part of this as well. To keep costs low, the possibility of fully developing only every second base and limiting the development of the others was examined. A review of other ground installations was required also, with a view of reducing expenditures as much as possible. Slemon, the Air Member for Operations and Training, was tasked with assessing the feasibility and efficiency of an air defence system with its early warning units located along the transcontinental line, including recommendations concerning where such units should be located. ${ }^{46}$

The recurring option analyses associated with the air defence plan may be viewed as symptomatic of the lack of a long-term vision, but this was not the case.

Technological advances in relation to weaponry, aircraft and radar capabilities within the context of changing levels of government support and financial commitment clearly made long term planning difficult. The RCAF was faced with the daunting task of protecting the second largest country in the world, which required that a wide range of factors be considered. Therefore, the evolutionary nature of the air defence plan was natural and reflective of the commitment of the RCAF to get it right.

\footnotetext{
${ }^{46}$ Ibid., p. 5.
} 
As had been inferred earlier by Air Vice Marshal James, before the revisions to the air defence plan were completed, a new treaty obligation was to affect how Canadian and air force made defensive preparations. Following extensive consultation, on 4 April 1949, 12 nations, including Canada, signed the North Atlantic Treaty. ${ }^{47}$ Amongst other things, this treaty included an article resolving "to unite their efforts for collective defence and for the preservation of peace and security". This undertaking for collective defence as part of NATO would sponsor unparalleled peacetime growth, planning and missions for the RCAF, which would be reflected in future plans.

Further discussions concerning the air defence plan were held on 16 May, at which time the requirement to move the Air Defence Group from Montreal to St. Hubert, Quebec, was approved. By doing so, this headquarters would avoid being in a likely enemy target area. It was also resolved that, in order to keep fighter bases sufficiently close to radar sites, to assign two squadrons each to North Bay and Ottawa, Ontario. Another two squadrons were designated for both Bagotville and Senneterre, Quebec. This co-location of fighters with radar allowed for more effective interception of attacking forces. One other fighter squadron and the operational training unit (OTU) were to be moved from St. Hubert to Chatham, New Brunswick. ${ }^{48}$

This series of events provided a good indication of the evolving professionalism in air force planning. The RCAF no longer planned only to satisfy government requirements for budgetary purposes. It spent significant time anticipating needs and developing contingencies. The decision to provide the government with multi-year plans

\footnotetext{
${ }^{47}$ Other treaty nations included Belgium, Denmark, France, Iceland, Italy, Luxembourg, the Netherlands, Norway, Portugal, the United Kingdom and the United States.

${ }^{48}$ DND, DHH, Raymont Papers, 73/1223, File 1820, Minutes of the $76^{\text {th }}$ Meeting of the Air Members, held at 1000 hours, $16^{\text {th }}$ May 1949 , pp. $2-5$.
} 
was a sound business decision and allowed better coordination of air force projects. The RCAF also acknowledged the political reality that funding was not unlimited. This led to a series of reviews with the purpose of reducing costs, even before tasked to do so by the government. Doing so undoubtedly contributed to the political and strategic effectiveness of the air force.

Prioritization of Air Force Tasks

In 1947, the newly formed Current Plans and Estimates Committee had identified a set of priorities for the air force. These demonstrated a willingness to work with the other services, as shown by the second highest priority being given to creation of the Joint Air School. ${ }^{49}$ The air force also showed a collaborative approach with the creation of maritime squadrons under Plan F. This was to change in 1949, when the RCAF tended to focus its efforts on tasks more closely aligned with independent, air force-related roles.

On 21 April 1949, Air Vice Marshal Dunlap identified the new priorities for RCAF activities. Personnel issues came foremost, with recruitment of ground crew heading the list, followed by the enrolment of aircrew. Training the new personnel, logically enough, was the second most important job, especially for critical trades like aircraft maintenance, radio operator, navigators and pilots. Air defence operational training came next, with a focus on Regular RCAF aid defence units, followed by Auxiliary and anti-aircraft units. Transport operations were assigned the fourth priority and then search and rescue operations. Government-directed photographic operations were seen as the next most important activity. At the bottom of the prioritized list were 
tactical operations (close air support for the army), training army paratroopers and maritime operations. ${ }^{50}$

This internal direction to the RCAF showed a strong orientation towards support for independent air force roles. The reason for giving emphasis to recruitment and training was fairly evident, since staffing shortfalls prevented the air force from fulfilling its mandate. In view of the threat appreciations and the substantial effort put into developing the air defence plan and Basic Security Plan, the importance of air defence operations was also obvious. However, the allocation of the lowest priority to support for the army and navy was a clear indication that the RCAF considered inter-service cooperation as less important than any other air force roles. This was contrary to Second World War experience, during which the requirement for the air force to fulfil a variety of roles, sometimes in support of the other services, was confirmed. For instance, during the war, 24 squadrons had served in the fighter and air cooperation role ${ }^{51}$ and another 15 as part of bomber command. ${ }^{52}$ Six wartime squadrons had provided airlift ${ }^{53}$ and up to eight had served in Coastal Command doing maritime operations. ${ }^{54}$ A substantial portion of air force wartime operations was in support of other services. With this reprioritization, the postwar RCAF all but abandoned the other services to their own devices.

\footnotetext{
${ }^{49}$ LAC, RG 24, Vol 5193, file 15-9-124, part 1, Minutes of the Third Meeting of the Current Plans and Estimates Committee Held in Room 2571, "A" Building at 1445 Hours, $15^{\text {th }}$ May 1947, file number S15-9124 (DOE), dated 20 May 1947.

${ }^{50}$ LAC, RG 24, Vol 5193, File 15-9-1, Part 1, letter S.44-1-23 (DOE), entitled "Priorities of RCAF Activities", dated 21 April 1949, from Air Vice Marshal C.R. Dunlap, to Air-Officer-Commanding, Central Air Command.

${ }^{51}$ Greenhous, op. cit., p. 180.

52 Ibid., p. 637.

${ }^{53}$ Ibid., p. 881 .
} 


\section{Long Range Plan}

Later during May 1949, the first version of the long range plan was briefed to air force leaders. This plan initially assumed that the RCAF would grow to the strength of 120,000 within a year of mobilization and be able to field 50 squadrons, which slightly exceeded the air force's overseas strength at the end of World War II. Force composition would include 29 fighter squadrons, six maritime squadrons, nine squadrons for short and long range transportation, two long-range reconnaissance squadrons, two long-range bomber squadrons, and two tactical bomber squadrons. It also divided plan implementation into three phases, with the first phase consisting of the Plan F peacetime force, Phase II reflecting the status one year after mobilization and Phase III detailing the expected wartime force of 120,000 , achieved three years after mobilization. This phasing identified the creation of the bomber squadrons as taking place during the third stage, since earlier establishment of them would affect the ability to produce sufficient fighters to satisfy Basic Security Plan commitments. Discussion led to the recommendation to decrease the number of fighter squadrons by two to 27 , thereby allowing the bomber force to grow to four squadrons. Planners were tasked with revising the long range plan accordingly and to reconsider the staging of Phase II in order to allow the earlier introduction of bombers. ${ }^{55}$

A month later, the revised long range plan was tabled. The Acting Air Member for Air Plans indicated that the plan now called for six bomber squadrons, resulting in a

\footnotetext{
${ }^{54}$ Ibid., p. 375. The total of these squadrons exceeds the total number of overseas squadrons because the role of some changed during the war, which resulted in a number of squadrons being counted more than once.
} 
decrease in the number of fighter squadrons to 22 . The overall reduction of fighter squadrons by seven in order to achieve four additional bomber squadrons was the result of the higher crew and support requirements for bombers. This had the overall effect of dropping the number of squadrons proposed under the long range plan from 50 to 47 . The RCAF Air Members decided to separate the long range plan into four phases, in order to better articulate the requirements needed in advance of mobilization. Following this change, Phase I would remain the same as before. A new Phase II expressed the need for a peacetime force capable of expanding to 120,000 three years after mobilization. Specifically, it advocated the addition of three squadrons and about 25,000 personnel from the limitations imposed by Plan F. The old Phase II became Phase III and the past Phase III became Phase IV. Phase III of the plan was approved for planning purposes and direction was provided on clarifying the first two phases. ${ }^{56}$

This long range plan is an example of forward thinking by the air force, but it also showed a return to the early postwar plans for a balanced, multi-purpose force. The second largest commitment for combat forces after the fighter squadrons was for the maritime and bomber roles, at six squadrons each. The latter was a main feature of RCAF wartime service and the senior leadership obviously wanted a return to this type of mission. There was a reasonable basis for advocating the bomber role, since this would have provided the kind of offensive capability favoured by Foulkes. The problem was that there was no policy basis for this function, as the government had yet to express a

${ }^{55}$ DND, DHH, Raymont Papers, 73/1223, File 1820, Minutes of the $77^{\text {th }}$ Meeting of the Air Members, held at 1430 hours, $25^{\text {th }}$ May 1949 , pp. 3-4.

${ }^{56}$ DND, DHH, Raymont Papers, 73/1223, File 1820, Minutes of the $81^{\text {st }}$ Meeting of the Air Members, held at 1430 hours, $22^{\text {nd }}$ June 1949 , pp. 2-3. 
desire for it. This would have to be resolved before the air force could commit resources to bombers.

\section{Changes to the Threat Environment}

In mid-June, the Chiefs of Staff Committee received an update on the status of the Basic Security Plan. It provided notification of the development earlier in the year of an emergency defence plan based upon currently available resources. ${ }^{57}$ This report showed that further progress had been made on defining the requirements of the Basic Security Plan but that plan implementation was being delayed because of a lack of an agreed intelligence estimate between the nations. The intelligence representatives tasked to support joint planning were asked to produce a new estimate in order to come to allow Basic Security Plan implementation to proceed. ${ }^{58}$

While awaiting this, the Chiefs of Staff considered some subordinate plans. As part of the overall military cooperation between Canada and the United States, a separate series of defence plans were established, ranging in topics from the aforementioned emergency defence plan, to a disaster recovery plan, to a plan for the defence of ports. One of these ancillary plans, on the vulnerability of vital points to air attack over the coming year, was completed in June 1949.

This plan identified a variety of ports, power stations, bridges, oil refineries, munitions and aircraft plants and atomic energy plants with some degree of

\footnotetext{
${ }^{57}$ DND, DHH, 193.009 (D 53), Box 5, Canada-United States Basic Security Plan Progress Report No. 9, file number JPC 17-14, dated 14 June 1949, pp. 1-2, attached to a letter from the office of the Secretary to the Chiefs of Staff Committee, entitled "Status of the Basic Security Plan", file number CSC 5-1-2, dated 13 July 1949.

${ }^{58}$ Ibid., pp. 2-3.
} 
vulnerability. ${ }^{59}$ It was based upon an assessment indicating that the Soviets, although not in possession of many long-range bombers and lacking in long-range bombing experience, would soon overcome these shortfalls and, during an attack, be able to cause enough damage to "vitally disrupt" Canada's economy. Whether by one- or two-way attacks, the Joint Planning Committee believed that the entirety of Canada could potentially be attacked from the air during the ensuing year. ${ }^{60}$ In assessing the vulnerability of Canadian targets from air, land or sea attack, the selection of which was influenced by their degree of importance to Canada's war effort, the Committee suggested that Montreal would be the foremost target due to its port, followed by the bridges at Windsor and Sarnia. Other vital points included Goose Bay for its airport, Halifax, Nova Scotia for its port and naval facilities, St. Johns, Newfoundland, and Victoria and Esquimalt, British Columbia for their naval bases and commercial ship repair capabilities, and St John, New Brunswick for its port. ${ }^{61}$

The reason Goose Bay airport was on this list was that it was an alternate landing site for other airports and helped stage trans-Atlantic flights. From a RCAF perspective, the presence of only one air-related target, namely Goose Bay, showed that the air force was not yet providing a vital defence capability. Deliberations by the Chiefs of Staff led to some questioning of the overall accuracy and value of this assessment, but in the end it was accepted as submitted. For his part, the Chief of the Air Staff thought that the identification of the vital points as targets was somewhat unrealistic in the near term, but

\footnotetext{
${ }^{59}$ DND, DHH 193.009 (D 53), Box 3, Extract of the $450^{\text {TH }}$ Chiefs of Staff Committee Meeting Held on 19 July 1949, enclosure JPC 19-1, entitled "Assessment of Vulnerability of Vital Points", dated 15 June 1949, Appendix A.

${ }^{60}$ Ibid., p. 2.

${ }^{61}$ Ibid., p. 6.
} 
that the assessment was worth considering as part of the overall process of planning air defensive measures. The other Chiefs of Staff accepted this point of view. ${ }^{62}$

Later in June 1949, the Canada-United States Joint Intelligence Committee released the anticipated updated and agreed intelligence appreciation examining probable Soviet courses of action against North America. This document was heavily influenced by the assessment of vital points, predicting that there would be extensive sabotage against key war industries, communications and transportation facilitates in advance of the commencement of hostilities and into the first phases of a conflict. Air attacks would supplement these covert attacks on vital points, with atomic and conventional bombs, and biological and chemical weapons being used to impair North American war production and to cause a large percentage of forces to be assigned to defensive roles. ${ }^{63}$ Estimates of Soviet industrial capacity to produce military hardware and existing military forces remained all but unchanged from the previous year, although the addition of an airborne refuelling capability resulted in all vital targets within Canada and the United States being within range on a two-way mission. ${ }^{64}$ This intelligence appreciation also estimated that the Soviet Union would not have an atomic bomb until mid-1950 at the earliest and most likely in mid-1953. With the latter of these two dates, the Soviet stockpile of atomic bombs was calculated to rise to around 20 by $1955 .{ }^{65}$

RCAF leadership became aware that earlier threat assessment assertions pertaining to the limited range of Soviet long-range bombers had been the result of a

\footnotetext{
${ }^{62}$ DND, DHH 193.009 (D 53), Box 3, Extract of the $450^{\mathrm{TH}}$ Chiefs of Staff Committee Meeting Held on 19 July 1949 , para 32.

${ }^{63}$ LAC, RG 24, Vol 20887, File 14.8.11.3. file number ACAI 5/2, entitled "Probable Soviet Courses of Action Against Canada, the United States and the Areas Adjacent thereto, 1 Jan 1957', dated 24 June 1949, pp. 3-4.

${ }^{64}$ Ibid., p. 35.

${ }^{65}$ Ibid., pp. 30.
} 
coordinated effort by American and Canadian army and navy representatives to minimize the danger posed to North America by aerial bombardment. The intelligence analysts from the other services also conspired to avoid mention of the possible development of a Soviet in-flight refuelling capability in the previous year's estimate. ${ }^{66}$ This had the overall effect in 1948 of diminishing the perception of the air threat. Cross-border interservice rivalry had influenced the advice given to senior government and defence authorities, in the hope of reducing the possible advantage of another service. Although this incident provided a demonstration of the army and navy's capacity to marginalize the air force, there should be no illusion that the RCAF was not equally capable of interpreting facts in a manner most advantageous to itself.

That summer the RCAF began the undoubtedly pleasant task of deciding how to deploy the new aircraft coming into service - up until that time, the air force could only shuffle wartime stock and speculate upon intentions. New aircraft procurement was expected to result in 32 CF-100 Canucks being produced during 1951, followed by the production of another five aircraft per month starting in 1952. Canadian-built F-86 Sabres were available earlier than that, with 15 aircraft being built during 1950 and a production rate of five per month thereafter. ${ }^{67}$ This required plans to be made on how to integrate into service a total of 15 new day interceptors in 1950, 92 new day and allweather fighters in 1951 and another 120 combat aircraft every year after that. At that rate, old aircraft could be retired fairly quickly. After two years, a new squadron could be formed almost every month.

\footnotetext{
${ }^{66}$ DND, DHH 193.009 (D 53), Box 3, memorandum HQTS 9042-30/2-1 (DMI), dated 22 August 1949, from W.A.B. Anderson, Colonel, DMI, to BGS (Plans), p. 1, attached to Extract from Minutes of the 454 ${ }^{\text {th }}$ Meeting of the Chiefs of Staff Committee, Held 15 November 1949.
} 
Recognizing that the defence of Canada came first and that this would necessitate the deployment of all-weather, long-range fighters, planners also realized that the RCAF had to have the capacity also to despatch aircraft on short notice overseas in time of emergency. Based upon recommendations put forward by Slemon, the RCAF decided to replace 12 Vampires with an equal number of Sabres at operational Regular Force units and to form five additional squadrons as operational aircraft became available. As more aircraft became available, the intention was to increase the number of aircraft per squadron from 12 to $16^{68}$

The role of the Auxiliary squadrons remained secondary. Their inventory of aircraft was limited to just four Vampires each, which was between a third and a quarter of the number of aircraft destined for Regular RCAF units. ${ }^{69}$ The problems with Auxiliary training remained a matter of concern, as members were encountering difficulties in achieving sufficient qualification to work on aircraft. Auxiliary squadrons were not capable of doing their own maintenance. In an attempt to resolve this, the proposal was put forward to simplify the Auxiliary trade structure. Regular RCAF technicians were always fully trained in their trade, which might include four subspecialties. For example, a Radar Technician might have qualifications A, B, C and D. Instead of training Auxiliary personnel to the same level, it was suggested that their technical education could focus on a single sub-specialty. One Reservist would be trained in area A, another in B and so on. This meant that, in the instance of Radar Technicians, it would take four Auxiliary members to do the same range of jobs as a

\footnotetext{
${ }^{67}$ DND, DHH, Raymont Papers, 73/1223, File 1820, Minutes of the $82^{\text {nd }}$ Meeting of the Air Members, held at 1430 hours, $14^{\text {th }}$ July 1949 , pp. 2-3.

${ }^{68}$ Ibid., pp. 5-6.

${ }^{69}$ Ibid., p. 4.
} 
Regular RCAF technician, but this approach would have the advantage of simplifying training. This approach was endorsed by Air Members. ${ }^{70}$

After a long period of making do with wartime stock, the air force was beginning to benefit from its efforts over the years. The arrival of new aircraft was the result of a combination of factors. The government became focused on building up the military as a result of the threat from the Soviet Union, which provided much of the impetus behind the air force expansion. Air force leaders contributed to this, as they became more politically effective in their dealings with the government. The role of RCAF planners should not be overlooked, as they were able to come forward with suitable means of responding to the changing security conditions.

\section{American and NATO Influences on Canadian Defence Planning}

The American Secretary of Defense, Louis Arthur Johnson, and the United States Ambassador to Canada, Laurence Steinhardt, met with the Cabinet Defence Committee in Ottawa on 11 August 1949. Prime Minister Louis St. Laurent was present. Minister of National Defence Claxton opened the meeting with comments regarding the ongoing threat to North America from the Soviet Union. He reviewed the now familiar anticipated strategy of the Soviet attacks on Europe, after which forward located airfields would be used to attack North America. The Canadian government believed that such attacks would be diversionary in nature. It was expected that, in the event of war, the Soviets would rely upon improved-design weapons being introduced to their forces. This upgrading of Soviet equipment was expected to continue for the next number of years. Claxton also indicated that, during any future conflict, Canada would likely assume roles

\footnotetext{
${ }^{70}$ Ibid., pp. 7-8.
} 
similar to those filled during World War II. This included convoy duties for the navy, a few army and air force units assigned within Canada for domestic security and the remainder sent out of country as part of an expeditionary force to support an allied strategic plan. Claxton finished with an expression of support for the ongoing defence collaboration under the Permanent Joint Board on Defence. $^{71}$

Johnson responded with the observation that the United States Joint Chiefs of Staff considered the prospects for peace much improved over the situation in 1948 . He attributed American support for Yugoslavia's break with the Soviet Union for helping to defuse international tensions. The threat to North America also seemed reduced because the expected timeline for the Soviet initial development of atomic weapons had been pushed back by a year, to 1951 . Soviet atomic initiatives were considered hindered by a shortage of uranium. Johnson predicted that, "[w]hile Russia had the will to fight, it was felt that they knew they lacked the necessary capability. So long as the Western Hemisphere maintained its economic and military strength, the threat of Russian aggression would continue to be checked. ${ }^{, 72}$

As a result of the creation of NATO, Johnson observed that the requirement to booster European security could affect Basic Security Plan implementation. The United States had good intelligence on Soviet supplies and reserves. In the event of war, the destruction of these was unlikely to end hostilities; the Soviet Union was expected to fight until completely defeated. This contributed to an American desire to help develop other western democratic defence forces, which could be used to counter Soviet

\footnotetext{
${ }^{71}$ LAC, RG 2, Vol 2748, VOl 4, Minutes of a Special Meeting of the Cabinet Defence Committee with the United States Secretary of State, held in the Privy Council Chamber, East Block, Parliament Buildings, Ottawa, on Thursday, August $11^{\text {th }}, 1949$, para 3, pp. 2-3.

${ }^{72}$ Ibid., para 4, pp. 3-4.
} 
aggression. The recent passing of the Military Assistance Bill was expected to facilitate this, with its focus on re-building European munitions industries instead of providing replacement arms of Canadian, American or British design. Other forms of military assistance could be provided to Europe, but President Truman was anxious that the defensive measures planned for Canada and the United States remain intact and undiminished. ${ }^{73}$

The Cabinet Defence Committee appeared worried that this support to Europe would reduce Canadian access to American arms. Claxton described the costs and problems for the Canadian military to deploy and train on both American and British equipment. The desire to replace older British equipment and to purchase and standardization on American gear was the preferred solution. ${ }^{74}$ Despite these concerns, the meeting concluded without a United States commitment to sell equipment to Canada or assurances that European rearmament would not affect Canadian access to American defence industries. Discussions on how Canada could aid European security were also delayed.

A little more than two weeks later, on 29 August 1949, the Soviet Union exploded its first atomic weapon. It was now only a matter of time before the Soviet Union would be able to produce bombs in operational quantities and, in doing so, would become a more pre-eminent threat. Because of this, yet another reassessment of Soviet strategic capabilities and intentions had to be undertaken in order to support Canadian, American

\footnotetext{
${ }_{73}^{73}$ Ibid., p. 4.

${ }^{74}$ Ibid., para 5, p. 5.
} 
and British long-term planning activities. ${ }^{75}$ The air defence mission of the RCAF, more so than before, became a matter of national priority.

Canada now became engaged in discussions about European defence. In the lead up to the establishment of NATO, Canada and the United States had attended Western Union Defence meetings as observers. On 13 September 1949, the Cabinet Defence Committee was briefed on meetings in Washington that looked into the defence organization established under NATO and on 17 September 1949, a communiqué was released in Washington describing the creation of a Defence Committee, a Military Committee and a Military Standing Group. To support these bodies, five Regional Planning Groups were also established. ${ }^{76}$ These Regional Planning Groups were responsible for "speedy and efficient planning of the unified defence of the whole North Atlantic area ... on a geographical basis." ${ }^{.77}$ There was the Northern Europe Regional Planning Group, ${ }^{78}$ Western European Regional Planning Group,${ }^{79}$ the Southern European - Western Mediterranean Regional Planning Group ${ }^{80}$ Canada - United States Regional Planning Group, and the North Atlantic Ocean Regional Planning Group. ${ }^{81}$

These groups were developing plans with varying degrees of success and participation. The United Kingdom was pressing the United States to abandon observer status with the Western European Regional Planning Group and to participate as a

\footnotetext{
${ }^{75}$ DND, DHH 193.009 (D 53), Box 3, letter CSC 14-8-11-2, entitled "Revision of ABC Intelligence", dated 10 November 1949, Appendix A, p. 1, from G.H. Newsome, Wing Commander, Secretary, Joint Intelligence Committee, to Secretary, Chiefs of Staff Committee, attached to Extract from Minutes of the $454^{\text {th }}$ Meeting of the Chiefs of Staff Committee, Held 15 November 1949.

${ }^{76}$ Dean Acheson, Secretary of State of the United States of America, Final Communiqué - North Atlantic Council, Washington, 17 September 1949, http://www.nato.int/docu/comm/49-95/c490917a.htm.

${ }^{77}$ Ibid.

${ }^{78}$ Consisting of Denmark, Norway and the United Kingdom. Ibid.

${ }^{79}$ Including Belgium, France, Luxembourg, the Netherlands, and the United Kingdom. Ibid.

${ }^{80}$ With France, Italy and the United Kingdom. Ibid.
} 
member of this group. There was a similar concern about the Western Mediterranean Regional Planning Group. It was understood by nations that full membership in a planning group implied a responsibility to provide resources to realize any plan agreed upon. Because of this implication for resources, Canada also had to decide whether it wanted observer or full membership on the Regional Planning Groups. ${ }^{82}$ There were also political reasons for Canada to be reticent about the degree of involvement with these groups. As the result of American concerns about security, the Canada - United States Chiefs of Staff Committee had agreed that the Canada - United States Regional Planning Group would not produce any detailed plans for submission to NATO ${ }^{83}$ This desire by the American Chiefs of Staff to keep European defence planning at arms length was consistent with the recent message from American Secretary of Defense Johnson. European rearmament and military preparedness was encouraged, but the security of North America was paramount. Accordingly, at least in the beginning, Canada's role in NATO planning was to be limited.

Prime Minister St. Laurent's concerns in this area were complementary to those of the Americans. He thought that Canadian participation in the planning groups should be on a permissive rather than compulsory basis. He preferred that Canada take some part in the development of NATO plans, but that this participation not be construed as a commitment to provide people or resources. This proved to be a contentious point for the Chief of the General Staff, who believed that continued Canadian participation in the

\footnotetext{
${ }^{81}$ Comprising Belgium, Canada, Denmark, France, Iceland, the Netherlands, Norway, Portugal, the United Kingdom and the United States. Ibid.

${ }^{82}$ LAC, RG 2, Vol 2748, Vol 4, Minutes of the Fifth-eighth Meeting of the Cabinet Defence Committee, held in the Privy Council Chamber, East Block, on Tuesday September $13^{\text {th }}, 1949$, para 1, p. 1.

${ }^{83}$ DND, DHH, 193.009 (D 53), Box 6, Jun-Apr 1950, Papers and Meetings, Chiefs of Staff Committee, April 1950, Vol 191, memorandum CSC 5-27-7, entitled "Short and Medium Term Defence Plans -
} 
group, whether as a participant or observer, would make it difficult to not commit forces later. From the NATO point of view, it "was recognized that it is the responsibility of individual governments to provide for the implementation of plans to which they have agreed." ${ }^{84}$ The Cabinet Defence Committee decided to support the work of the various Regional Planning Groups without clarifying Canada's role as an observer or member, ${ }^{85}$ which did little to clarify for other NATO participants the nature and extent of Canada's intentions to participate in joint defence.

The concerns US Secretary of Defense Johnson had about European rearmament were reflected in his approach to his new NATO allies. A meeting of the NATO Defence Committee was held in Paris on 1 December 1949, at which the allies endorsed a strategic concept for the "integrated defence of the North Atlantic area". A common approach to the production and delivery of military arms and equipment was also agreed upon. Despite these agreements, there was unrest amongst some allies with how quickly the Americans wanted action to be taken within NATO, described by some as approaching "almost indecent haste". Claxton observed that "Johnson's steamrolling created some resentment" in some quarters, while other nations appreciated that action needed to take place. ${ }^{86}$ These difficulties with the American approach to NATO would resurface again early in the new year.

The latter part of 1949 was a busy period for the three services. The Soviet threat was more palpable because of the atomic bomb test, which made the chance of conflict

NATO", from Chairman, Chiefs of Staff Committee to Chairman, Joint Planning Committee, dated 25 April 1950.

${ }^{84}$ Dean Acheson, Secretary of State of the United States of America, Final Communiqué - North Atlantic Council, Washington, 17 September 1949, http://www.nato.int/docu/comm/49-95/c490917a.htm.

${ }^{85}$ LAC, RG 2, Vol 2748, Vol 4, Minutes of the Fifth-eighth Meeting of the Cabinet Defence Committee, held in the Privy Council Chamber, East Block, on Tuesday September $13^{\text {th }}, 1949$, paras 2-8, pp. 2-3. 
seem more likely. This forced Canadian and American governments to consider speedier implementation of security measures, which would necessitate additional resources to be devoted to defence. Moreover, as NATO evolved, alliance commitments were likely to necessitate Canadian participation. The Cold War developments fostered an environment favourable to growth within the Canadian military.

\section{Changes to Canadian Defence Planning}

In October 1949, the defence programme released by Claxton focused squarely on the threat of communism and the Soviet Union. He warned that "the only kind of war which would involve Canada would be a war in which Communism was seeking to dominate the free nations ... Such a war would be a war of survival." After describing the importance of NATO and bi-lateral defence cooperation with the United States, he also clearly indicated that Canada's role in such a conflict would be as part of a coalition, not a direct confrontation of the USSR by Canada alone. ${ }^{87}$ The lack of restraint in this statement was a departure from the more traditional moderation shown by Canadian politicians and bureaucrats. ${ }^{88}$ But it did reflect the urgency felt within Canada to rearm and anxiety over the Soviet threat.

An updated strategic appreciation was provided to the Cabinet Defence Committee on 23 November 1949, which took into consideration the knowledge of Soviet atomic capability. It remained a concern that the Soviet Union had sufficient

\footnotetext{
${ }^{86}$ James Eayrs,_In Defence of Canada - Growing Up Allied (Toronto: University of Toronto Press, 1980), p. 166.

${ }^{87}$ Government of Canada, Canada's Defence Programme, 1949-1950 (Ottawa: DND, 1949), p. 15. Quoted from Richter, Avoiding Armageddon, p. 16.

${ }^{88}$ See John English, "A Fine Romance": Canada and the United Nations, 1943-1957", pp. 73-89, in Greg Donaghy, ed., Canada and the Cold War, 1943-1957 (N.p.: Department of Foreign Affairs and International Trade, 1998).
} 
forces to overrun Europe. Such an attack would likely be accompanied by air attacks against Canada and the United States. Since long-range aircraft would not be required to attack Europe, recent significant developments in the production of these aircraft demonstrated a greater risk to North America. It at least showed that the Soviets were considering such attacks. In view of the new Soviet ability to build atomic bombs, this threat could no longer be considered as simply diversionary. ${ }^{89}$

Claxton believed that Canada could no longer count on having the time to recruit, train and equip forces after the outbreak of hostilities. He anticipated that adequate forces were now required before the start of a conflict to defend against a potential atomic attack. There likely no longer would be a grace period that would allow mobilization of the military reserves or the training of new recruits. He directed the Chiefs of Staff to prepare a plan for "the minimum forces necessary for the defence of Canada and at the same time for maximum development potential". Since modern defence equipment took several years to build and deliver, Claxton understood that service plans would have to consider phased construction and implementation programs. This required a process that would support funding spread over several years. ${ }^{90}$ This was precisely the planning approach put forward by the RCAF in March of that year. The Prime Minister supported the creation of a more comprehensive approach for defence planning that considered expenditures over a number of years. The Cabinet Defence Committee endorsed the creation of a five year planning cycle. ${ }^{91}$

\footnotetext{
${ }^{89}$ LAC, RG 2, Vol 2748, Vol 4, Minutes of the Sixtieth Meeting of the Cabinet Defence Committee, held on Wednesday November $23^{\text {rd }}, 1949$, in Room 201, House of Commons, para 12-13, pp. 4-5.

${ }^{90}$ LAC, RG 2, Vol 2748, Vol 4, Minutes of the Sixtieth Meeting of the Cabinet Defence Committee, held on Wednesday November $23^{\text {rd }}, 1949$, in Room 201, House of Commons, para 13, p. 5.

${ }^{91}$ Ibid., paras 15-16, p. 6
} 
The adoption of an expanded planning cycle was to have lasting implications for RCAF planning. This process, initially advocated by Air Vice Marshal James, provided the basis for long-term defence planning. It allowed the RCAF, as well as the other Services, to stage activities, spreading the cost over a number of years, because of the assurance that funding would be available over the long-term. It also helped with the coordination of different elements of RCAF plans, as it facilitated the phased introduction of new capabilities through staging such elements as the construction of facilities, the introduction of new equipment, and the recruitment and training of personnel as part of an overall program. This process placed RCAF planning on a sounder, more professional basis. An associated minor change brought about by the adoption of multi-year planning was that it stopped the air force practice of giving alphabetical designations to its annual plans and estimates after the revised Plan $\mathrm{H}$ in 1952, which is beyond the scope of this thesis. Afterwards, the annual RCAF plans became "Programmes of Activities", which were characterized by the detailed cost analyses covering multiple years.

Before 1949 ended, the Cabinet Defence Committee met to discuss long term defence plans and Canada's defence role within NATO. A NATO "Strategic Guidance" paper indicated that the organization's military goal was to develop sufficient military strength to discourage the Soviet Union from aggression. If this did not work, the western democracies needed enough defence capability to quickly defeat the Soviet Union on the battlefield. NATO nations had to create and maintain balanced, effective defence forces that could be combined to work together in times of emergency. ${ }^{92}$ The requirement for balanced forces within NATO would soon become important to Canada.

\footnotetext{
${ }^{92}$ LAC, RG 2, Vol 2748, Vol 4, Minutes of the Sixty-first meeting of the Cabinet Defence Committee, held on Thursday, December $22^{\text {nd }}, 1949$ in the Privy Council Chamber, para 1, p.2.
} 
The role of Canada and the United States was different from that of other NATO nations. Each of the regional groups was responsible for defending territory within its geographic boundaries. Additional tasks were given to select groups due to their geographic location and their military capabilities. The Canada-United States Regional Planning Group was given the responsibility for planning for the quick reinforcement of any region under attack. This group was given the task of planning an immediate air counter-attack against any aggressor. The United States intended to prepare military formations capable of reinforcing any region and Canada was tasked with developing plans to augment these with uncommitted land and air forces. ${ }^{93}$

To create the forces for this kind of deployment, Foulkes wanted to assign only the very minimum of resources possible to defending North America. This approach would have the dual benefit of allowing Canada to provide the greatest contribution possible in the quickest time and with the least expense to Canada, since it was designed to fully use available forces. He recommended that the personnel and resources sent to support NATO allies be employed primarily in offensive operations; as emphasized earlier, Canadian troops focusing on the offensive was a favourite topic for Foulkes. In his opinion, Canada's defence effort should be changed to reflect this kind of orientation and focus. ${ }^{94}$

Foulkes went on to indicate that one of the principles of NATO defence planning was the creation of an overall balanced military force from across the entire organization. Canada did not require its own balanced and integrated forces, but instead could concentrate in areas that best suited it and in which the biggest contribution could be

\footnotetext{
${ }^{93}$ Ibid.

${ }^{94}$ Ibid.
} 
made at the lowest cost to Canadians. ${ }^{95}$ This advice to the Cabinet Defence Committee resulted in good support to NATO, but it could also be interpreted as modifying Claxton's defence policy statement of 1947. That statement put the defence of Canada as the military's primary goal and military cooperation with other nations as the third most important task. Foulkes' recommendation to allocate only the minimum forces necessary for the defence of North America could be seen as at least reducing the emphasis put on Canadian security. However, the range of modern weaponry allowed attacks to come from well beyond Canadian borders, so a strategy of fighting battles as far as possible away from Canada made good sense.

Air Vice Marshal Wilf Curtis then briefed the Cabinet Defence Committee on air force intentions. For the 1950-51 budget year, he expressed support for a Regular RCAF establishment of five fighter squadrons, one maritime squadron, three transport squadrons, a photography reconnaissance squadron and a medium bomber squadron. This represented one more fighter squadron, one less maritime squadron and two less long range reconnaissance squadrons than was intended under Plan F. The request for the medium bomber squadron was also put forward from the 1952-53 fiscal year; no reasoning for this change was provided. The plans for the Auxiliary during this period remained unchanged from Plan F, with 10 fighter squadrons and two tactical bombing squadrons identified as requirements. ${ }^{96}$

These resources would be used to carry out a modified air defence plan that would concentrate Regular RCAF squadrons and radar stations in the vital Quebec-MontrealOttawa-Toronto corridor. As a result of current manpower shortages, the radar stations

\footnotetext{
${ }^{95}$ Ibid.

${ }^{96}$ Ibid., para 6, p. 4.
} 
would be manned only part time, so they would not constitute an early warning system. To address this, Curtis argued that in the event of war, these radar stations could be used for training of Western Europeans, who had little access to training facilities. ${ }^{97}$ To implement this programme, he said that 204 F-86 day interceptor type aircraft and 112 F100 all-weather fighters were needed. An additional $26 \mathrm{C}-119$ transport and 16 maritime patrol aircraft were also required. Curtis concluded with the observation that strategic indications showed the need to accelerate, not slow down, defence programmes. Air defence was necessary at the outbreak of conflict, so the government could not plan on building the system afterwards. ${ }^{98}$

In combination with the other services, proposed defence expenditures for 195051 totalled $\$ 614$ million $^{99}$, a considerable increase from the $\$ 372$ million spent the year before. ${ }^{100}$ Because of this high cost for defence, Prime Minister St. Laurent thought that calculated risks had to be accepted and consideration given to eliminating or delaying some of the proposed defensive measures. Foulkes suggested that, should the full requested amount not be available, either the plans had to be redone completely or some delays be accepted in their implementation. He did not believe that the current plans could be achieved through simple reductions to the amount spent on different components. The Cabinet Defence Committee took this under advisement. ${ }^{101}$

Budgetary approval was later provided for defence spending of $\$ 425$ million. Consultation between the service chiefs resulted in a division of $\$ 20$ million for

\footnotetext{
${ }^{97}$ Ibid.

98 Ibid., paras 6-7, p. 5 .

${ }^{99}$ Ibid., para 9, p. 5.

${ }^{100} \mathrm{http} / /$ www.nato.int/archives/1 st5years/annexes/a5.htm.

${ }^{101}$ LAC, RG 2, Vol 2748, Vol 4, Minutes of the Sixty-first meeting of the Cabinet Defence Committee, held on Thursday, December $22^{\text {nd }}, 1949$ in the Privy Council Chamber, paras 9-11, p.5
} 
administration, $\$ 24$ million for defence research, $\$ 82$ million for the navy, $\$ 130$ million for the army and $\$ 169$ million for the air force. This represented some reduction in the percentage of defence spending previously given to the army and an increase in the air force's share. ${ }^{102}$ In fact, this allocation of funds represented a first-time shift between the relative levels of peacetime support provided to these two services; all previous budgets had given the most money to the army. The RCAF would continue throughout the 1950s to obtain the largest share of the budget than the other services. Table 7 shows this trend during the first part of the decade. As percentages, during this period, the air force share of the overall defence rose from 42.5 percent in 1951 to 49.4 percent in 1953. During this same period, the army fell from 39.2 percent to 33.8 percent and the navy dropped from 18.4 percent to 16.8 percent. In the battle for budget share, the RCAF was winning.

Table 7: Comparison of Peacetime Defence Budgets, 1951-53 ${ }^{103}$

\begin{tabular}{|c|c|c|c|}
\hline & 1951 & 1952 & 1953 \\
\hline RCAF & $230,553,393$ & $601,972,759$ & $768,040,774$ \\
\hline Canadian Army & $211,779,075$ & $424,028,509$ & $526,057,265$ \\
\hline RCN & $99,849,081$ & $182,371,218$ & $260,295,546$ \\
\hline
\end{tabular}

There are a myriad of factors in the RCAF's budgetary growth in comparison to the army. The threat to North America was generally conceded to consist largely of an air threat and the Basic Security Plan's response to it necessitated the creation of a large fighter-interceptor system. The Soviet acquisition of atomic weapons made the case for an air defence system for Canada all the more compelling. The RCAF budget share was

\footnotetext{
${ }^{102}$ LAC, RG 2, Vol 2748, Vol 4, Minutes of the Sixty-second Meeting of the Cabinet Defence Committee, held on Friday, February $17^{\text {th }}, 1950$, in the Privy Council Chamber, para 20, p. 5.

${ }^{103}$ Government of Canada, Report of the Department of National Defence for the Fiscal Year Ending March 311953 (Ottawa: Queen's Printer,1953), pp. 103-104.
} 
also influenced by the need to obtain new aircraft with modern technology, which had the side political and economic benefit of helping to nurture a domestic aircraft manufacturing capability. Canadian geography was another consideration, since the huge, largely uninhabited land mass that constitutes Canada could not reasonably be defended effectively by an army. The RCAF, on the other hand, could provide a quick reaction capability to any intrusion on Canadian soil.

\section{Conclusion}

The RCAF had progressed from putting together the Basic Security Plan to deciding on implementation measures. A large component of this was the air defence plan, which considered command and control issues and examined whether to have fighter squadrons co-located with population centres or to take a defence in depth approach. The end result was a combination of the two, with some squadrons to be located in the north and the others situated near cities. An influence on this decision was the political direction to focus units on population and industrial centres.

This period also saw significant changes to the role of the RCAF Auxiliary. It began the postwar period as a major component of the air force's defensive strategy to protect North American airspace. By the end of the decade, recruitment, training and equipment problems rendered the Auxiliary nearly impotent and this was reflected in the decisions to remove the operational roles from the organization. The Auxiliary never really recovered from this and was destined to play a minor role in the postwar air force. $^{104}$

\footnotetext{
${ }^{104}$ For a more complete description of the plight of the Auxiliary, see Sandy Babcock, "Withered on the Vine: The Postwar RCAF Auxiliary", in Yves Tremblay, ed., Canadian Military History Since the $17^{\text {th }}$
} 
The highlight for the year for the RCAF was likely the activities associated with the introduction of new aircraft. Previously, financial restrictions and the absence of political will combined to make technological upgrades to the air force fleet impossible. As 1950 approached, the RCAF received approval for two new versions of fighters, which would be received at a rate that would soon permit the creation of almost a full squadron a month. Considering the lack of combat effectiveness up to that date, this represented a decisive change of fortunes for the air force. The threat environment was the major contributor to these new circumstances and the Soviet Union explosion of its first atomic weapon was a factor in this. The government accepted the existence of an air threat to Canada and supported increased defence measures. The air force was the major beneficiary of this and the nature of the air threat resulted in the primary rebuilding focus being on fighter-interceptors. The Cold War was shaping the postwar RCAF.

Circumstances also improved for the RCAF when additional defence commitments came forward. The threat from the Soviet Union was explicitly recognized by Canada, as well as other countries. Western democracies, led by the United States, formed a defensive alliance, which Canada joined as a charter member. The establishment of NATO resulted in another round of defence planning similar to that experienced with the Basic Security Plan, although the extent and nature of Canadian participation remained unresolved. The RCAF would take part in these discussions and additional operational roles resulted. Between the Basic Security Plan and NATO, the Cold War was providing the impetus and justification for air force growth.

Century: Proceedings of the Canadian Military History Conference, Ottawa, 5-9 May 2000 (Ottawa: Directorate of History and Heritage, 2000). 
A major change to air force planning was the adoption of multi-year plans. This facilitated phased and integrated introduction of program components, so that longer term planning could take place and there could be a degree of confidence of the level of funding available in the future. The RCAF demonstrated a higher level of skill than in the past when developing its plans, taking into consideration a wider range of factors including political, financial and technological. This was reflected in the level of political effectiveness achieved, as the air force was able to obtain the largest share of the defence budget for the first time. This development amply demonstrates that the RCAF had achieved some measure of political effectiveness. Approval and financial support for the multi-year plans by the government showed agreement with the overall direction of the air force and demonstrated a correlation between RCAF goals and achievements. The RCAF improved effectiveness after obtaining government support for changes to organization and structure in order to better respond to operational demands and, in doing so, displayed reciprocity between the political and air force leadership. The politicians required sovereignty to be maintained and the Quebec City - Windsor industrial corridor to be protected; the air defence plan addressed these concerns. The air force ensured that fiscal concerns were considered, which tended to be a primary focus of the government. As another example of the reciprocity between the government and the RCAF, the air defence plan necessitated the manufacturing of additional aircraft and the benefits accrued for Canadian industry in addressing this shortfall satisfied some political goals. This political effectiveness was critical to the success and growth of Canada's Cold War air force. 
The RCAF continued to demonstrate an increased level of professionalism. The multi-year approach to defence planning is an example of improved management and planning techniques, since it allowed large projects to be developed, financed and phased in over a number of years. This approach also allowed the RCAF to better define and defend its interests to the government. In addition, the air force showed a high level of professional skill by changing organizationally to take into consideration the technical innovations brought about by the Basic Security Plan. The command and control plans for air defence are a reflection of this and provides an example of the kind of enhanced self-administration of the military anticipated by Janowitz. Moreover, air force leadership continued to take a pragmatic approach to defence planning, recognizing that issues external to national defence affected what could be done.

Improvements to planning process allowed the RCAF to obtain political support for a force designed to counter the Cold War threat posed by the Soviets. The air force had evolved into a stronger, more confident entity, which capably dealt with the government and the other services in order to further organizational goals. Measurements of this success include increased budget share, equipment acquisitions and recognition for expertise. The air force was becoming more professional is its dealings with the government and the other services. But this was not the end of the RCAF's growth. The final chapter of this thesis will detail new initiatives and expanded roles for the air force, which resulted in even greater achievements by the RCAF. 


\section{CHAPTER SIX}

\section{A REVITALIZED AIR FORCE:}

\section{RCAF NATO AND AIR DEFENCE PLANNING, 1950}

Beginning in 1950, the RCAF experienced a period of unparalleled peacetime expansion. This can be attributed to a number of factors. The Cabinet Defence Committee under Prime Minister Louis St. Laurent proved very supportive of defence initiatives. Brooke Claxton, as Minister of National Defence, ably facilitated these on behalf of the government. With the outbreak of the Korean Conflict, the threat from the Soviet Union was perceived as becoming more serious and there was increased impetus behind establishing a credible military counterbalance across NATO. Simultaneously, the RCAF was refining and fielding segments of the air defence measures for North America. During this year, the RCAF received approval for an increase from nine Regular force squadrons and 10 Auxiliary squadrons in early 1950 to a force of 28 (16 Regular and 12 Auxiliary), followed by approval for a further expansion to more than 40 squadrons (29 Regular and 12 Auxiliary). This peacetime growth in approved establishment by more than $100 \%$ over a little more than 12 months was remarkable.

This chapter will examine the increased importance of NATO for the RCAF and the manner in which it affected planning, as well as the nature, composition and mission of the air force. The political and military reaction to the Korean Conflict will be reviewed and will provide the context for much of this expansion. The development and revision of RCAF Plan G will be reviewed, as will the background work associated with the development of its successor in 1951, Plan H. Canada and the United States 
continued to cooperatively plan and implement air defence measures for North America, but a difference in national approaches to NATO planning became evident and a source of frustration for the Canadian military. Yet the RCAF's ability to produce effective plans during this period directly contributed to the air force's success and growth.

\section{Updated Threat Appreciations}

The new decade began with an updated assessment from the Joint Intelligence Staff. Examining the potential threat from the Soviet Union from 1 July $1951-1$ July 1954, this appraisal introduced concerns about clandestine attack. It considered the possibility of the Soviets disguising bombers or commercial transport aircraft with Canadian or American insignias or the markings of major foreign air carrier. Concealed in this manner, the Soviet aircraft could release an atomic weapon mid-air over a target or the bomb could be detonated after landing near a critical area with no warning. The assessment also warned about the potential surreptitious laying of atomic mines in major harbours by merchant ships of Soviet or Soviet Bloc registry. Such weapons could be deployed through special external openings in the hull or simply dropped overboard. The possibility of using up to a 400 -day time delay mechanism meant that these weapons could be pre-positioned well in advance of an attack. A third area of concern about covert attack related to the detonation of weapons aboard ships moored in important harbours. ${ }^{1}$ Another means of secretive attack would be to smuggle weapons into North

\footnotetext{
${ }^{1}$ LAC, RG 24, Vol 20888, file 14-8-11-5, Vol 1, JIC 14-8-11-5, Vol 1, "ACAI 9, 10, 11, 12 - Forms and Scales of Soviet Attack Against North America - 1 July 1951 and 1 July, 54", Enclosure A, entitled "Preliminary and Tentative Study of Soviet Unconventional Use of Weapons (Mid-1951)", dated 13 January 1950, pp. 1-2.
} 
America as part of a diplomatic shipment ${ }^{2}$ or aboard small sea-going vessels, such as yachts or fishing boats, under the control of Soviet agents. ${ }^{3}$ This threat assessment also discussed the danger from guided missiles with atomic warheads launched from merchant ships or submarines and from atomic torpedoes. ${ }^{4}$

This assessment was a departure from its predecessors. Previous documents focused on military threats from bombers, and land and maritime forces, engaged in traditional military forms of attacks. The new assessment largely ignored these and focused almost exclusively on more covert and unconventional means of aggression. This appraisal clearly highlighted more unlikely avenues of Soviet attack, but it also demonstrated a measure of professionalism and thoroughness by the intelligence staffs. It explicitly looked at alternatives beyond the traditional forms of warfare, denoting a more comprehensive approach to military planning activities.

Additional documentation attached to this assessment showed that the Canadian and American intelligence communities favoured different approaches when producing threat assessments. The Americans wanted to formulate their assessments as if any Soviet Union attack would have a single focus, in the form of an all-out effort against North America. Canada preferred a broader approach, taking into consideration Soviet global military commitments in the event of hostilities. This included a belief that the USSR would have to allocate a portion of their atomic stockpile for operations against the United Kingdom, instead of the American suggestion that all such weapons could be targeted on Canada and the United States. The Canadian representatives also argued that any such assessments had to examine a wide range of strategic factors when determining

\footnotetext{
${ }^{2}$ Ibid., p. 3

${ }^{3}$ Ibid., p. 4.
} 
Soviet strategy, such as political and economic considerations, while the Americans sought to include only military aspects. ${ }^{5}$ This willingness of the Canadians to challenge the American viewpoint of the threat environment showed a measure of independence and an ability to develop strategic appreciations on their own.

Soon thereafter, another threat assessment was produced that was more in line with past efforts. ${ }^{6}$ This draft document ${ }^{7}$ deviated little from the traditional appreciations developed in the postwar period, although the previous practice of assessing likely Soviet capabilities five to ten years into the future had been shortened to four years (1954), an approach that had started with the assessment released earlier in the month. Past attempts to project a decade into the future had proven inaccurate, partially because the speed of technological, social, economic and political change reduced the ability of the intelligence community to forecast the future.

This latest assessment included some details relevant for the Royal Canadian Air Force. Questions were introduced about the likelihood of the Soviet air force to operate effectively at very long range by 1954 . In part, this was because of the number of older, obsolete Soviet aircraft that required replacement, the absence of suitable logistical support for long range operations and inadequate training and maintenance support. ${ }^{8}$ If

\footnotetext{
${ }^{4}$ Ibid., p. 2.

${ }^{5}$ LAC, RG 24, Vol 20888, file 14-8-11-5, Vol 1, JIC 14-8-11-5, Vol 1, "ACAI 9, 10, 11, 12 - Forms and Scales of Soviet Attack Against North America - 1 July 1951 and 1 July, 54", enclosure entitled "Report on Joint U.S. - Canadian Intelligence Conference 24 April to 11 May 50", dated 15 May 1950, by T.R. McCoy, Lieutenant-Colonel, Chairman, Joint Intelligence Staff Team, pp. 1-3.

${ }^{6}$ LAC, RG 24, Vol 20888, file 14-8-11-4, Vol 1, A.C.A.I. 5/3, entitled "Forms and Scales of Soviet Attack Against North America Assuming a War on 1 July 1954", dated 17 January 1950.

${ }^{7}$ This document was produced solely by Canada and was used as an opening Canadian position in negotiations with the United States to produce a joint threat appreciation. It is not known what form the final, joint document took.

${ }^{8}$ LAC, RG 24, Vol 20888, file 14-8-11-4, Vol 1, A.C.A.I. 5/3, entitled "Forms and Scales of Soviet Attack Against North America Assuming a War on 1 July 1954", dated 17 January 1950, pp. 29-31.
} 
this were true, the Canadian and American implementation of an air defence system had additional time in which to become operational.

An associated development was the broadening horizon for Canadian military operations. With the introduction of NATO, Canadian and American intelligence organizations considered the military capabilities of allies in Europe. Their assessment was that "[d]espite improvement in the overall economy of the Allies, main reliance for support of a prolonged war will depend on the resources of Canada and the United States." $" 9$

The air force paid little attention to the possibility that the Soviet ability to attack over long distances was limited and becoming less effective. There was no discernable difference in the focus of plans, which continued to concentrate on the development of a fighter-interceptor force to counter possible Soviet air operations. Considering the potential devastation coming from an atomic attack, this was likely prudent and appropriate. Besides, a series of developments soon rendered any likelihood of restraint being exercised in air force planning moot. But before this occurred, the RCAF and the government continued during the first part of the year in a manner similar to that during the latter part of the 1940s.

Planning in Early 1950

In the first half of the year, the air force was involved in implementing the plans approved in December 1949 by the Cabinet Defence Committee, which included a Regular RCAF establishment of five fighter squadrons, one maritime squadron, three

\footnotetext{
${ }^{9}$ LAC, RG 24, Vol 20888, file 14-8-11-4, Vol 1, JPC 17-18, entitled "Strategic Appreciation Terms of Reference", dated 16 February 1950, p. 1.
} 
transport squadrons, a photography reconnaissance squadron and a medium bomber squadron. ${ }^{10}$ It was also engaged in routine development of the next iteration of the annual RCAF plan, which took the form of Plan G. The air force also worked on improving the Auxiliary and on establishing guidelines for cooperation with the army. The level of operational readiness of the Auxiliary Air Force continued to pose difficulties for the Royal Canadian Air Force. At a special meeting of the Air Members held on 22 and 24 February, discussion focused on the Auxiliary's shortfalls in the area of ground organization, which included aircraft maintenance. While actual air operations were "reasonably satisfactory", the state of non-flying operations was such that Auxiliary Squadrons were incapable of achieving operational readiness within 90 days of mobilization, ${ }^{11}$ which was the reduced standard identified for the Auxiliary just the previous year. To compensate for this, a series of recommendations were adopted, including the formation of Reserve Technical Training Squadrons and the creation of interim trade qualifications. ${ }^{12}$ The Air Members resisted any suggestion that full-time trade instructors be made available to the Auxiliary squadrons. ${ }^{13}$

Cooperation between the air force and army was the subject of a study conducted by Air Commodore M. Costello, Group Commander, Tactical Group Headquarters and Brigadier G. Kitching, Commander Designate, Active Force Brigade Group. In examining the kind of operations required in the event of an enemy landing in remote parts of northern Canada, these commanders developed a plan to satisfy the Mobile

\footnotetext{
${ }^{10}$ LAC, RG 2, Vol 2748, Vol 4, Minutes of the Sixty-first meeting of the Cabinet Defence Committee, held on Thursday, December $22^{\text {nd }}, 1949$ in the Privy Council Chamber.

${ }^{11}$ DND, DHH, 73/1223, File 1821, Appendix A to Minutes of the $96^{\text {th }}$ Meeting of the Air Members, "Minutes of Meetings to Discuss Recommendations Contained in the Report on RCAF Reserve Operational Squadrons, Held on 22 and 24 February, 1950", p. 1.

${ }_{12}$ Ibid., pp. 2-3.

${ }^{13}$ Ibid., p. 4.
} 
Striking Force requirement of the Basic Security Plan. This document anticipated the possibility of an enemy force of up to 100 men being landed by air or submarine, which would launch offensive operations. In addition to responding to such an encroachment, the Mobile Striking Force could be used to counter subversive activities, airborne assaults against isolated locations in Alaska and the Aleutian Islands, and small sabotage parties landed by submarines. ${ }^{14}$ Canadian planning anticipated army requirements to consist of two airborne battalion groups immediately, followed by an additional battalion 90 days later if required. Air force participation in such a Mobile Striking Force included two light bomber squadrons, 30 transport aircraft and eight gliders. After 30 days following the commencement of operations, an additional 20 transport aircraft would be required. ${ }^{15}$ The options of ignoring such enemy landings in anticipation of the climate and adverse conditions rendering these forces ineffective or of simply containing the enemy to a small area were essentially rejected out of hand. The favoured approach was to "attack and destroy the enemy" quickly. ${ }^{16}$ An immediately identified shortfall for the air force was the requirement to obtain additional transport aircraft in order to move an army battalion group, consisting of about 1200 men, at one time. ${ }^{17}$ When this document was considered by the Chiefs of Staff Committee in May 1950, the Chief of the General Staff argued that the Mobile Striking Force should be provided with close air support, should the operations be within the range of the fighters. Following discussion, the Chiefs of Staff

\footnotetext{
${ }^{14}$ DND, DHH, 193.009 (D 53), Box 7, May 1950, Vol 92, CSC papers, attached to Extract from the "Minutes of the $464^{\text {th }}$ Meeting of the Chiefs of Staff Committee, Held 31 May 1950", Air Force File TS 2-1 (Tac Gp HQ), entitled "The Employment of the Mobile Striking Force for the Reduction of Enemy Lodgements in Canada", dated 27 January 1950, p. 3.

${ }^{15}$ Ibid., p. 4.

${ }^{16}$ Ibid., p. 6.

${ }^{17}$ Ibid., p. 9.
} 
Committee agreed with Foulkes and had the Mobile Striking Force plan revised to include fighter support. ${ }^{18}$

The Mobile Striking Force Plan was improved and another version of it was released in November. The composition of the force essentially remained unchanged, although in the case of the air force, the units to be involved with the Mobile Striking Force were identified. The light bomber capability was to be provided by the Auxiliary squadrons located in Saskatoon and Edmonton, and the fighter bomber squadrons were the Auxiliary squadrons in Calgary and Winnipeg. ${ }^{19}$ The army units would operate from main bases in Edmonton, Winnipeg and Moncton, from where they would be despatched to advanced bases (through staging bases if required), in order to attack any enemy lodgement. For Edmonton, likely advanced bases were in Fort Nelson, Whitehorse, Yellowknife and Norman Wells. For Winnipeg, Churchill, Coral Harbour and Resolute were candidates as advanced bases. Moncton's candidate's for advanced bases included Goose Bay, Chimo and Frobisher Bay. In addition to providing air support (air strike and reconnaissance) and transportation (movement of army personnel to staging and advanced bases, logistical support and for airborne assaults), the RCAF was also responsible for providing security for the advanced bases, with the exception of Churchill, Manitoba, which already had army forces position there. ${ }^{20}$ This represented a substantial commitment for the RCAF.

\footnotetext{
${ }^{18}$ DND, DHH, 193.009 (D 53), Box 7, May 1950, Vol 92, CSC papers, attached to Extract from the "Minutes of the $464^{\text {th }}$ Meeting of the Chiefs of Staff Committee, Held 31 May 1950", paras 38-40.

${ }^{19}$ DND, DHH, 193.009 (D 53), Box 6, January - April 1950, Papers and Meetings - Chiefs of Staff Papers for 1950, file CSC 5-11-12-1, paper 36 (50), "Mobile Striking Force Plan for Reduction of Enemy Lodgements in Northern Canada", by T.G. Gibson, Brigadier, Commander, Active Force Brigade Group and M. Costello, Air Commodore, Group Commander, Tactical Group Headquarters, dated 13 November 1950, pp. 5-6.

${ }^{20}$ Ibid., pp. 8-14.
} 
These activities, while important, essentially represented the status quo for the air force. Oversight of the Auxiliary RCAF continued to progress, albeit slowly and with difficulties. More positive developments were associated with the articulation of the plan in support of the Mobile Striking Force, but this did not significantly involve the fighting capability of the Regular RCAF, which was largely tasked with providing transportation support to the army. The Auxiliary was responsible for most of the combat-related operations associated with the Mobile Striking Force.

\section{Preliminary Cabinet Defence Committee Direction - 1950}

At the beginning of the year, Cabinet direction to National Defence continued in a routine manner. In preparation for a mid-February meeting of the Cabinet Defence Committee, the air force prepared a proposal for its 1950-51 programme, which became the initial basis for Plan G. This proposal advocated activating five regular force fighter squadrons (Chatham, New Brunswick, Bagotville and Montreal, Quebec, and Trenton and Toronto, Ontario) to establish an air defence system for the eastern industrial area of Canada. ${ }^{21}$ This was an increase of two over the three squadrons tasked in this role the previous year. These squadrons were to be supported by radar stations located near to the fighter bases, the cost of which would be offset by the elimination of four radar sites already approved by Cabinet as part of the Model Interceptor Plan. In another move, the air force sought to reduce the number of squadrons dedicated to photographic operations from three down to a single squadron, with one of the two remaining squadrons converted to a maritime role and the personnel from the other squadron transferred to air 
defence duties. ${ }^{22}$ Auxiliary squadrons would also be increased, from ten to twelve. The net result of these changes is shown in Table 8.

Table 8: RCAF REQUIREMENTS - 1950

\begin{tabular}{|c|c|c|c|c|}
\hline$\underline{\text { Regular }}$ & Squadrons & $\begin{array}{l}\text { Aircraft per } \\
\text { Squadron }\end{array}$ & $\begin{array}{c}\text { Total CF 100s } \\
\text { by } 1955\end{array}$ & $\begin{array}{c}\text { Total F-86s } \\
\text { by } 1955\end{array}$ \\
\hline All Weather & 2 & 12 & 24 & \\
\hline Day Interceptors & 3 & 12 & & 36 \\
\hline \multicolumn{5}{|l|}{ Auxiliary } \\
\hline Day Interceptors & 4 & 4 & & 16 \\
\hline Day Interceptors & $\begin{array}{c}2 \\
\text { (Vampires) }\end{array}$ & & & \\
\hline Day Interceptors & $\begin{array}{c}2 \text { (Trainers } \\
\text { only) }\end{array}$ & & & \\
\hline Fighter Bomber & 2 & 4 & & 8 \\
\hline Total in Use & & & 24 & 60 \\
\hline $\begin{array}{l}\text { Training Test Work- } \\
\text { shop Reserve and } \\
\text { Wastage Replacement }\end{array}$ & & & 36 & 76 \\
\hline Total Requirement & & & 60 & 136 \\
\hline
\end{tabular}

This proposal met with approval from the government. When the Cabinet Defence Committee met on 17 February, it noted that the army had a budget of $\$ 130$ million, the air force had $\$ 169$ million and the Navy $\$ 82$ million. Following briefings from the Chiefs of Staff, the Committee approved the expenditures for 1950-51, including those proposed by the air force. In addition to the aircraft types detailed in Table 8, authority was also provided to the air force for the purchase 37 Chipmunk light training aircraft. ${ }^{23}$

\footnotetext{
${ }^{21}$ DND, DHH, 193.007 (D 53), Box 7, July 1950, Vol 94, CSC papers, enclosure to "Extract from Minutes of the $457^{\text {th }}$ Meeting - Chiefs of Staff Committee, 16 Feb 50", entitled "Royal Canadian Air Force - 195051 Programme", Draft, dated 15 Feb 50, p. 1.

${ }^{22}$ Ibid.

${ }^{23}$ LAC, RG 2, Vol 2748, Vol 4, "The Sixty-Second Meeting of the Cabinet Defence Committee held on Friday, February $17^{\text {th }}, 1950$ at 11:30 A.M. in the Privy Council Chamber, pp. 5-6, paras 20-26.
} 
While matters proceeded routinely on the domestic front, developments within NATO promised to be more interesting and complex. The NATO Defence Committee met on 1 April 1950 in The Hague, at which European unease about American expectations for NATO resurfaced. Representatives from the Netherlands, Belgium and France informed Claxton that they resented "the bull-headed and inconsiderate way in which the Americans were telling [them] to change their plans". For instance, the Netherlands had a naval tradition, but the United States advised the Dutch not to proceed with building a new naval base, cruisers and destroyers, but instead to concentrate on developing an army and air force. The Dutch Defence Minister had informed Claxton of this "with anger and almost despair... Belgians and French complained of similarly heavy-handed treatment by the Americans". But when Claxton attempted to sensitize US Secretary of Defense Johnson to these concerns, Johnson reacted "surprised, upset, and, in his naïve ignorance of the way other nations felt, more hurt than anything else ... [asking] 'How could these others be so ungrateful for what the US and himself were doing?",24

Notwithstanding these European concerns, Claxton was sympathetic to American difficulties with progress within NATO. He believed that:

... the Americans had cause for concern was plain. How could the Administration or Defense Department justify giving aid to countries and put large forces in Europe unless the Europeans were moving promptly to help themselves? Not one of the three countries was taking its military commitments very seriously at the time. The Americans felt that the Alliance must "get on with it",; if NATO was to progress at all they must play their part. ${ }^{25}$

\footnotetext{
${ }^{24}$ Eayrs, op. cit., pp. 166-167.

${ }^{25}$ Ibid., p. 167.
} 
But even Claxton's viewpoint of the dilemma of defence spending within NATO was challenged. Escott Reid, Deputy Undersecretary of State for External Affairs, believed that the United States did not expect the creation of the alliance to result in any increase in defence spending by its European allies. Instead, by sharing resources, it was anticipated that total defence budgets amongst the allies could be reduced. Reid argued that the American State Department "believed that the mere commitment of the United States to the alliance would be enough to deter the Soviet Union from committing aggression. The United States administration hoped that there would be "some increase" in the defence expenditures of the Western European allies but it also believed that "economic recovery must not be sacrificed to rearmament". ${ }^{26}$

Claxton also noted that it was difficult to progress initiatives at NATO Defence Council meetings, with discussion "almost impossible". Instead, the most promising course of action appeared to involve presenting the Council with the completed work of subsidiary committees for approval, which tended to avoid "awkward questions". ${ }^{27}$ This emphasized the importance of the work done by such bodies as the Regional Planning Groups.

A Canadian diplomat at the NATO meeting in The Hague expressed the opinion that "the military plan approved by the Defence Ministers is not one which they expect can ever be put into effect.... Until the United States is committed to a military and economic aid programme for her North Atlantic partners until at least $1954, \ldots$ the security of the North Atlantic Community will continue to rest more on political bluff

\footnotetext{
${ }^{26}$ William Johnston, A War of Patrols - Canadian Army Operations in Korea (Vancouver: UBC Press, 2003), p. 13, quoted from Escott Reid, Radical Mandarin: The Memoirs of Escott Reid (Toronto: University of Toronto Press, 1989), p. 238-9.

${ }^{27}$ Eayrs, op. cit., p. 167
} 
than on military and economic strength..."28 NATO was a "paper tiger". Claxton saw things essentially the same. Across NATO, there were large gaps between plans and capabilities. Many nations could not field the military forces required by the alliance. European alliance members were also apprehensive about whether American assistance to military programmes would continue into the future. This engendered a lack of confidence that hindered efforts to standardize equipment across NATO and the recovery of national economies. ${ }^{29}$

It was not just the European allies that needed to support NATO more. In the first half of 1950 , the Canadian contribution to NATO planning was somewhat limited. The Cabinet Defence Committee, under the chairmanship of Prime Minister St. Laurent, met on 25 April 1950, and Brooke Claxton tabled the recently received NATO Medium Term Defence Plan. From a Canadian perspective, this document proved to be too ambitious and poorly thought out, although the specific nature of these demands was not disclosed. In fact, neither Canada nor the United States had contributed to the development of this plan in their role as the only two members of NATO's Canada - United States Regional Planning Group. Claxton observed that "[t]he Medium Term Defence Plan was a conglomeration of plans which had not yet been fully integrated, resulting in the force requirements which had been added together to indicate the total N.A.T.O. force requirements. ${ }^{30}$ The excessive requirements identified were considered impossible to achieve by 1954 and meant that the Military Production and Supply Board and the Defence Finance and Economic Committee had embarked on projects based upon an

\footnotetext{
${ }^{28}$ Ibid., p. 198.

${ }^{29}$ Ibid., p. 199.

${ }^{30}$ LAC, RG 2, Vol 2748, Vol 4, "The Sixty-Fourth Meeting of the Cabinet Defence Committee held in the Privy Council Chamber on Tuesday, April $15^{\text {th }}, 1950$ at 11:00 a.m.”, p. 8, para 7.
} 
unrealistic plan. ${ }^{31}$ This Medium Term Defence Plan appeared to have been arrived at by simply summarizing the large requests contained in the various regional group requirements, with no effort being made to rationalize or coordinate these disparate plans into a single, coherent document. The Prime Minister and the Secretary of State for External Affairs undertook to introduce the Canadian concerns at an upcoming meeting of the North Atlantic Council, with the intention of advocating a more realistic approach to alliance defence planning. ${ }^{32}$

- The Canadian perspective on participation in NATO planning was changing. On 25 April 1950, Lieutenant General Foulkes reminded the Chairman, Joint Planning Committee, of the agreement with the American Chiefs of Staff, due to American security concerns, for the Canada - United States Regional Planning Group (CUSRPG) to avoid producing detailed plans for submission to NATO. He noted that at the early April Hague meeting of the NATO Defence Council there "was considerable uneasiness on the part of the countries comprising of other groups veering on suspicion and doubt regarding the intentions of Canada and the United States". Specifically, the European allies had observed that the CUSRPG plan "indicated no force requirements and in fact added little if anything to the Medium Term Defence Plan". In view of this, Foulkes directed the Joint Planning Committee to inform American planners of a Canadian preference for their Regional Planning Group to produce more realistic Short and Medium Term Plans for sharing with NATO. ${ }^{33}$ In this instance, Short Term Plans related

\footnotetext{
${ }^{31}$ Ibid.

${ }^{32}$ Ibid., pp 9-10, para 35.

${ }^{33}$ DND, DHH, 193.009 (D 53), Box 6, Jun-Apr 1950, Papers and Meetings, Chiefs of Staff Committee, April 1950, Vol 191, memorandum CSC 5-27-7, entitled "Short and Medium Term Defence Plans NATO", from Chairman, Chiefs of Staff Committee to Chairman, Joint Planning Committee, dated 25 April 1950.
} 
to those military forces available by July 1951 , while Medium Term Plans anticipated the forces that would be available for July 1954, which corresponded with when the Soviets were believed capable of launching a major atomic attack.

During the first part of 1950 , Canadian politicians and military planners found themselves in an awkward position between NATO and the United States. Canada had an interest in supporting NATO, but this had limitations. For instance, Canadians appeared to understand European concerns about how NATO was developing, but at the same time sympathetic with the American desires to see more from the European allies rather than be in a position to finance western rearmament. Canada had similar apprehensions along these lines, as the requirements of the Medium Term Plan were found to be excessive and Canada was unwilling to endorse it. In the absence of significant change, the road ahead for NATO was likely to be difficult.

In the meanwhile, on the domestic front, the government's approval of the RCAF requirements for 1950 represented continued success for the air force in accelerating the reestablishment of an effective fighting force. Plan F in 1949 had anticipated just two Regular Force fighter squadrons in the 1950/51 fiscal year and an increase to four such squadrons the following year. But the RCAF was able to obtain approval for the creation of a total of five Regular Force fighter squadrons during 1950, which is demonstrative of their planning abilities and the level of political support they enjoyed. This situation would continue to improve over time, as event conspired to make the air force a prime candidate for further expansion. 
Korea

On 25 June 1950, with assistance and training from the Chinese and Russians, the North Korea People's Army swept into South Korea, quickly making significant gains against Republic of Korea army units. On June $27^{\text {th }}$, American air and naval forces began providing covering support for South Korean troops and on the same date, a Security Council motion was passed allowing "members of the United Nations [to] furnish such assistance to the Republic of Korea as may be necessary to repel the armed attack and to restore international peace and security in the area."34 ${ }^{, 34}$ conflict galvanized the western democracies, including Canada, into a frenzy of defensive preparations and planning in support of NATO. Claxton later observed that:

NATO owes the fact that it has built up its strength to the communist aggression in Korea. ... To meet the challenge of Korea required a build-up of our forces comparable to what was needed to meet our commitments in Europe. Almost more important is the change that it made in public opinion. Korea made our people realize what was involved in communist aggression and what was needed to stop it. Moreover it accustomed the people of Canada (and of other NATO countries) to the idea of having large numbers of men and large amounts of money tied up in our common effort to protect our freedom.

The momentum we gained in the Korea war carried through to the build-up of our collective strength in Europe. In Canada we did everything possible to bring it home to the people that Korea and NATO were just two aspects of the same operation; two places where we met the communist challenge in precisely the same way, namely by building up our strength. ${ }^{35}$

In mid-July, Claxton called a special meeting of the Chiefs of Staff Committee to obtain advice on what defensive measures Canada should take in view of the Korean

\footnotetext{
${ }^{34}$ Johnston, op. cit., p. 20.

${ }^{35}$ Eayrs, op. cit., p. 200.
} 
Conflict. Chief of the Air Staff Curtis informed his advisors that he would seek a

moderate increase in the current air programme, consisting of another two or three fighter squadrons, a portion of which could be used, if required, in Korea. He also confirmed the immediate availability of 100 North American P-51 Mustangs from the United States, ${ }^{36}$ which in ways was a step backwards because these aircraft had been eliminated from the RCAF inventory in $1947 .^{37}$

At the 17 July meeting, the Deputy Minister of National Defence, Charles Mills (Bud) Drury, suggested that "apart from the question of direct support to the Korean war, it might be well to consider what defence measures should be taken at this time to improve our general defence position." Claxton amplified this by indicating that the Chiefs of Staff should "consider what measures could be taken to improve local defences within present resources and what further steps could be taken if additional funds were available." From this, it may be deduced that the Cabinet Defence Committee was still unsure of what kind of impact the Korean Conflict and related developments could have on Canada. The Chiefs of Staff were relatively conservative in their requests, with the army and navy simply asking for more personnel and the air force seeking increased air frame and air engine production. Chief of the General Staff Foulkes also reported that the three services were developing contingency plans for the acceleration of their defence programmes. The Minister asked to be briefed on these the following day. ${ }^{38}$

\footnotetext{
${ }^{36}$ LAC, RG 24, Vol 6175, memorandum 19-9-72, no title, from CAS to Air Members, 12 July 1950. ${ }^{37}$ LAC, RG 24, Vol 5193, File 15-9-124, Part 1, Minutes of the Fifth Meeting of the AMAP Current Plans and Estimates Committee, Held in Room 2511, "A" Building, at 1430 hrs, $21^{\text {st }}$ August 1947, file S15-9-124 (DOE), dated 29 August 1947.

${ }^{38}$ DND, DHH, 193.007 (D 53), Box 7, July 1950, Vol 94, "Extract from Minutes of Chiefs of Staff Meeting Held in the Office of the Minister, 17 July 50 ".
} 
Curtis embraced this opportunity and, at the next day's meeting, requested a series of measures. He sought the immediate purchase of 100 Mustangs from the USAF and an increased rate of production of F 86 Sabres, CF 100 Canucks and aircraft engines. He had additional requests related to a large number of aircraft for maritime and transport squadrons. ${ }^{39}$ The army and navy also submitted requests for additional equipment. These proposals, when they became known within the Department of External Affairs, resulted in expressions of concern that the military was not going far enough. One member of the diplomatic corps wrote to a senior bureaucrat:

I gather that National Defence are proposing rather modest increases in the Defence programme with a view to speeding up re-equipment of Canadian forces ... I think it would be a great pity if Cabinet got the impression that this is all that needs to be done. You might like to have a word with the Minister, pointing this out to him and suggesting that he might like to bring into the discussion the very great need for building up our European allies. It seems to me that the Korean situation underlines the necessity for forces in being and on the ground prepared to offer effective assistance from the outset, rather than mobilization potential ... ${ }^{40}$

On 19 July 1950, Claxton briefed the Cabinet Defence Committee, beginning with an assessment of how the conflict could impact the security situation. He indicated that it was considered unlikely that a major war with the Soviet Union would result from Korea, although there was a risk of war between the United States and China because of the American guarantee of Formosa's security. Nonetheless, it was expected that the Soviet Union would attempt to exploit favourable conditions elsewhere (Hong Kong, Indo-China, Siam, Burma, Malaya, Iran, Greek Macedonia, Yugoslavia and Berlin). Direct conflict between the western democracies and the Soviet Union would likely not take place before the Soviets had stockpiled atomic bombs and strengthened their armed

\footnotetext{
${ }^{39}$ DND, DHH, 73/1233/1305, Minutes of a Special Meeting of CSC, 18 July 1950, p. 4.

${ }^{40}$ Eayrs, op. cit., p. 201.
} 
forces and economy, which would not likely occur during 1950. However, the Korean Conflict was considered indicative of the willingness for both sides to take risks and the potential of a major war was higher as a result. ${ }^{41}$

Claxton also expressed concerns that the Korean Conflict had wider implications for Canada and its allies. Claxton feared that American focus on Korea denied western Europe trained reinforcements in the event of attack. American Reserves such as the National Guard could be deployed to support NATO, but he anticipated that this would entail a long training delay that could be exploited by the USSR. ${ }^{42}$ These anxieties found a receptive audience in the Cabinet Defence Committee, with the Secretary of State for External Affairs Pearson voicing the opinion that the risk of major war stemming from the Korean situation was higher than was being suggested. ${ }^{43}$

The Minister of National Defence went on to describe the forms of Canadian assistance being sought by the United States and the United Nations to support Korean operations. In addition to land and maritime forces, feedback on the availability of longrange air transport was solicited. The air force was able to help out in this regard by providing up to ten North Star transport aircraft within three months. ${ }^{44}$ He added that the Korean Conflict had shown how unprepared NATO nations were for war and expressed support for the acceleration of Canadian defence initiatives in order to strengthen NATO $^{45}$

\footnotetext{
${ }^{41}$ LAC, RG 2, Vol 2748, Vol 4, "The Sixty Fifth Meeting of the Cabinet Defence Committee held in the Privy Council Chamber on Wednesday, July19, 1950, at 9:30 a.m.", pp. 1-2

${ }^{42}$ Ibid., pp. 2-3.

${ }^{43}$ Ibid., p. 3.

${ }^{44}$ Ibid., p. 4.

${ }^{45}$ Ibid., p. 6.
} 
Claxton concluded by describing the proposals for defensive improvements from the Chiefs of Staff. For the RCAF, it included increasing the F 86 production from five to seven per month and the CF 100 production from three to five per month. This would allow the establishment of three F 86 squadrons of 25 aircraft each by July 1952 and two CF 100 squadrons of 18 aircraft each by December 1952. In the interim, the fighter strength of the air force could be enhanced through the immediate purchase of the Mustangs. ${ }^{46}$ The increases sought by the Chiefs of Staff would cost about an additional $\$ 50$ million over the $\$ 381$ million already approved for their services and would require larger establishments by another five to six thousand over current staffing levels. ${ }^{47}$ Following discussion, these measures were approved by the Cabinet Defence Committee. $^{48}$

The Korean Conflict had immediately seized the attention of the political leadership and provided an opportunity for the Canadian military to advance their interests in a Janowitzian manner. Yet the recent proposals from the services must be viewed as moderate and in line with ongoing force development measures. The immediate reaction of the services was not to promote their interests unduly. The RCAF's focus was on speeding up the production, delivery and fielding of its new aircraft, augmented by the addition of the Second World War era Mustangs. If anything, these measures demonstrated a tendency towards adherence to existing plans, which suggests that the air force had achieved a measure of effectiveness that it was comfortable with.

\footnotetext{
${ }^{46}$ Ibid., p. 7.

${ }^{47}$ Ibid.

${ }^{48}$ Ibid., p. 8.
} 


\section{Short and Medium Term Plans}

The second half of 1950 saw an intensive period of planning activities within the RCAF, including the development of studies into short and medium term requirements to support NATO. The plans that were produced were to serve as a basis for mobilization in the event of war and demonstrated the increasing capabilities of the air force to prepare for the future.

In response to the direction from the Chairman, Chiefs of Staff Committee, the Joint Planning Committee put together recommendations for the Canadian contribution to the CUSRPG Short Term Plan. For the air force, this consisted of a commitment to have an increasing number of squadrons available in the period following the commencement of military operations (D-Day). Table 9 details the level of forces to be committed by the RCAF. In addition to these squadrons, the RCAF also undertook to provide three additional squadrons (Day Interceptor, Troop Carrier and Heavy Transport) for reinforcement to other NATO areas by 90 days after mobilization. In total, this represented a promise to provide up to $14 \frac{1 / 2}{2}$ flying squadrons (plus a single Aircraft Control and Warning Group) to NATO within three months of the outbreak of hostilities. ${ }^{49}$ An important difference was that previous contributions to NATO-related plans had the caveat that forces would be available only if North America had not been

Table 9: RCAF Contribution for the CUSRPG Short Term Plan (1950)

\begin{tabular}{|l|l|l|l|l|l|l|}
\hline & D-Day & $\begin{array}{l}\mathrm{D}+15 \\
\text { Days }\end{array}$ & $\begin{array}{l}\mathrm{D}+30 \\
\text { Days }\end{array}$ & $\begin{array}{l}\mathrm{D}+60 \\
\text { Days }\end{array}$ & $\begin{array}{l}\mathrm{D}+90 \\
\text { Days }\end{array}$ & $\begin{array}{l}\mathrm{D}+180 \\
\text { Days }\end{array}$ \\
\hline
\end{tabular}

\footnotetext{
${ }^{49}$ LAC, RG 24, Vol 6177, file 19-81-2, JPC 5-27-7-6, "Short Term Plan - CUSPG (CUS -3)", from W. Weiser, Wing Commander, Acting Secretary, Joint Planning Committee, to Secretary, Chiefs of Staff Committee, dated 24 August 1950, Appendix B and Appendix F.
} 


\begin{tabular}{|l|c|c|c|c|c|c|}
\hline $\begin{array}{l}\text { Day Fighter } \\
\text { Squadrons }\end{array}$ & 1 & 3 & 3 & 3 & $6 \frac{1 / 2}{2}$ & $61 / 2$ \\
\hline $\begin{array}{l}\text { Troop Carrier } \\
\text { Squadrons }\end{array}$ & 2 & 2 & 2 & 2 & 2 & 2 \\
\hline $\begin{array}{l}\text { Area } \\
\text { Reconnaissance } \\
\text { Squadrons }\end{array}$ & 1 & 1 & 1 & 1 & 1 & 1 \\
\hline $\begin{array}{l}\text { Tactical } \\
\text { Bomber } \\
\text { Squadrons }\end{array}$ & 1 & 1 & 1 & 1 & 1 & 1 \\
\hline $\begin{array}{l}\text { Aircraft } \\
\text { Control and } \\
\text { Warning } \\
\text { Groups }\end{array}$ & & & & & & 2 \\
\hline
\end{tabular}

attacked by 90 days after the beginning of operations. This restriction had been eliminated, although a measure of caution was still exercised through the inclusion of the statement that these forces "probably" could be made available for NATO. ${ }^{50}$ The willingness of the air force to provide such a level of support for NATO is a perceptible shift from previous plans which emphasized North American defence primarily, which may be attributed to such factors as changing political attitudes, confidence in the growing strength of the RCAF to meet multiple demands and an increased realization of the importance of participation in the alliance.

The ongoing change to the Canadian approach to the strategic situation was amply demonstrated at the next meeting of the Chiefs of Staff Committee. The committee supported the Canadian input for the CUSRPG Short Term Plan as a basis for negotiating with the Americans with minor amendments suggested by the Secretary to the Cabinet, Norman Robertson. He added that "it was for consideration as to whether air forces in Western Europe would not be of greater value in the defence of Western Europe than

${ }^{50}$ Ibid., p.1. 
ground forces at $\mathrm{D}$ plus 6 months. If such were the case, the peace-time organization of the Canadian armed forces would require certain changes in order to make available additional air forces for pre-D-Day duty in Europe". ${ }^{51}$ Robertson's rationale for prepositioning the RCAF in Europe in advance of hostilities may have been similar to Mackenzie King's decision to support air training in Canada at the start of the war, which was an attempt to avoid high army causalities during combat. Whatever the reason, the prospect of pre-deploying squadrons on European soil during peacetime was now on the table.

Consultation with the Americans led to some additional roles in the CUSRPG Short Term Plan for the RCAF. The United States Air Force intended to send large bombers to the European theatre of operations as required and needed a staging base for the trans-Atlantic flights. To this end, Goose Bay and Gander, Newfoundland were to be used to support Strategic Air Command heavy bombers and Military Air Transport Services cargo aircraft respectively. ${ }^{52}$ The RCAF also assumed the responsibility for providing three shore-based Maritime Air Squadrons by six months after the start of a war, ${ }^{53}$ which brought the total number of squadrons allotted for this plan to $171 / 2$. Concurrent with this work on the Short Term Plan, the RCAF was also developing a Medium Term War Plan in support of the Basic Security Plan and NATO commitments. As a result of a growing perception that the Soviet Union and its allies could be prepared for war earlier than anticipated, the Medium Term War Plan noted a

\footnotetext{
${ }^{51}$ LAC, RG 24, Vol 6177, file 19-81-2, Extract of Minutes of $472^{\text {nd }}$ Meeting of the Chiefs of Staff Committee, Held 30 August 1950.

${ }^{52}$ LAC, RG 24, Vol 6177, file 19-81-2, Memorandum TS 19-81-2 (DAPS) entitled "Force Tabs - RCAF ANORG Short Term Plan - Submitted for NAOR DP 2/50 dated 24 Aug 50", from K.L.B. Hodson, G/C, DAPS to D/AMAP/P, attached Message A 104, DTG 012100Z 1 Dec 50.
} 
requirement to change the planning horizon from 1956 to 1 July 1954. In developing this plan, the air force considered the vital targets that required protection and found that an area defence approach, which was already the basis for planning, was more effective than a point defence system. The anticipated disposition of bases and squadrons was found to provide adequate coverage of vital points without significant changes to the current implementation approach. The Medium Term War Plan also noted that in order to be operationally proficient for the 1954 target date, the air defence system would have to be in place for 1 October 1953, so that the system, equipment and personnel could be trained and developed as an integrated force. ${ }^{54}$

Supporting documentation for the Medium Term War Plan demonstrated both the change in RCAF fortunes and the ability of air force planners to increasingly deal with complex issues, albeit considerations associated with national industrial capabilities were found to be wanting. This plan called for up to 39 squadrons, 697 operational aircraft and 4516 crew. ${ }^{55}$ Table 10 describes the nature of these squadrons, aircraft and personnel. To support this number of aircraft and aircrew, over 1 million rounds of .303 ammunition, around 20 million .5 ammunition and almost $300,00016 \frac{1}{2}$ pound practice bombs would be required for training purposes alone. Operationally, each of the nine CF 100 fighter squadrons would require $64,800.5$ rounds and 7,200 2.75 inch rockets per month.

\footnotetext{
${ }^{53}$ LAC, RG 24, Vol 6177, file 19-81-2, Memorandum TS 19-81-2 (DAPS) entitled "Force Tabs - RCAF ANORG Short Term Plan - Submitted for NAOR DP 2/50 dated 24 Aug 50", from K.L.B. Hodson, G/C, DAPS to D/AMAP/P.

${ }^{54}$ LAC, RG 24, Vol 6177, file 1981-3, Vol 1, letter TS 4-2-3 (Gp Cdr), entitled "Basic Security Plan Medium Term - Air Defence Requirements", from W.R. MacBrien G/C, Group Commander, ADGp, to CAS, dated 1 Sep 50, pp. 1-2.

${ }^{55}$ LAC, RG 24, Vol 6177, file 1981-3, Vol 1, memorandum TS 19-81-3, entitled "RCAF Medium War Plan - Calculation of Ammunition and Bomb Requirements", from R.M. Trites, W/C, CAW, to AMTS, dated 14 August 1950.
} 
Similarly, each of the eight F-86 squadron needed $61,200.5$ rounds monthly. ${ }^{56}$ If this plan came to implementation, it represented a massive and expensive undertaking. In fact, a subsequent staff check on the feasibility of Canadian industry to support the Medium Term War Plan, which included aircraft and communications equipment production, found it wanting. The plan was "beyond our capacity without extensive logistic aid from foreign sources", the availability of which was unknown. ${ }^{57}$

Table 10: RCAF Medium Term War Plan Requirements (1950)

\begin{tabular}{|c|c|c|c|c|c|c|}
\hline Sqn Type & Squadrons & $\begin{array}{c}\text { Aircraft per } \\
\text { Squadron }\end{array}$ & $\begin{array}{c}\text { Crew } \\
\text { Factor }\end{array}$ & $\begin{array}{c}\text { Personnel } \\
\text { per Crew }\end{array}$ & $\begin{array}{c}\text { Number of } \\
\text { Crew }\end{array}$ & $\begin{array}{c}\text { Number of } \\
\text { Personnel }\end{array}$ \\
\hline CF 100 & 9 & 25 & 1.4 & 2 & 315 & 630 \\
\hline F-86 & 8 & 25 & 1.4 & 1 & 280 & 280 \\
\hline $\begin{array}{c}\text { Maritime - } \\
\text { Lancaster }\end{array}$ & 6 & 12 & 1.5 & 9 & 180 & 972 \\
\hline $\begin{array}{c}\text { Area Recce } \\
\text { Lancaster }\end{array}$ & 1 & 12 & 1.5 & 9 & 18 & 162 \\
\hline $\begin{array}{c}\text { Bomber - } \\
\text { B 50 } 59\end{array}$ & 6 & 10 & 2 & 11 & 120 & 1320 \\
\hline $\begin{array}{c}\text { Transport - } \\
\text { Phase 1 }\end{array}$ & 5 & 16 & 1.5 & 6 & 120 & 720 \\
\hline $\begin{array}{c}\text { Transport - } \\
\text { Phase 2 }\end{array}$ & 4 & 12 & 1.5 & 6 & 72 & 432 \\
\hline Totals & 39 & 697 & & & & 4516 \\
\hline
\end{tabular}

The Medium Term War Plan also required substantial financial commitment from the government, totally over $\$ 300$ million just for spare parts, telecommunications and

\footnotetext{
${ }^{56}$ LAC, RG 24, Vol 6177, file 1981-3, Vol 1, memorandum TS 19-81-3, entitled "RCAF Medium War Plan - Calculation of Ammunition and Bomb Requirements", from R.M. Trites, W/C, CAW, to AMTS, dated 14 August 1950.

${ }^{57}$ LAC, RG 24, Vol 6177, file 1981-1, Vol 1, memorandum TS 19-81-3 (CLP), entitled "RCAF Medium Term War Plan - Feasibility", from E.C. Luke, G/C, CLP to D/AMP/P, dated 18 December 1950. ${ }^{58}$ Ibid.

${ }^{59}$ The rationale behind inclusion of the B 50 Superfortress bomber lacks any background or supporting documentation. The B 50 was a modified wartime B-29 long range bomber used to deliver atomic weapons, and the RCAF had neither a long range bombing role nor atomic weapons. This aircraft also was having developmental problems and was obsolete by 1951, leaving the USAF's inventory by 1953. http://www.globalsecurity.org/wmd/systems/b-50.htm
} 
general equipment, which excluded the cost of aircraft production, munitions, fuel and airfield preparations. ${ }^{60}$ The demands posed by this plan were such that the government directed that its contents were not to be released to NATO pending Cabinet approval, leaving the RCAF in a position that only the intentions of Plan G or the RCAF Programme 1951-54 could be released out of the country. ${ }^{61}$

Despite this activity on development of Canada's support for NATO's Short and Medium Term Plans, relatively little of it was actually reaching NATO. Ongoing negotiations with the Americans to produce a joint submission on behalf of the Canada United States Regional Planning Group continued to encounter difficulties. At the fifth meeting of the CUSRPG in Ottawa, 14-18 September 1950, the Canadian delegation found the "reasons for not determining the overall regional force requirements, as requested by the Standing Group, and then determining what each country's commitment should be are inexplicable." ${ }^{.62}$ In a report to the Canadian section of the Permanent Joint Board on Defence's MCC, it was noted that:

US Planners refuse to produce realistic defence plans under the auspices of the [CUSRPG], claiming that all that is required for the Standing Group is an informative document, and not a document which should be passed to Commanders as a basis for operational planning.

... In attempting to produce a realistic Medium Term Defence Plan, it was discovered immediately that the Canadian representatives and the US representatives had a different approach towards meeting the requirements of [NATO]. These differences have resulted in the omission from the Medium Term Plan of all matters deemed essential by the Canadian representatives. The US representatives stated that the plan could not be

\footnotetext{
${ }^{60}$ LAC, RG 24, Vol 6177, file 1981-1, Vol 1, memorandum TS 7-1-3 (SPCSO) entitled "RCAF Medium Term War Plan - Requirements", from C.A. Cook, G/C to CAS, dated 27 November 1950.

${ }^{61}$ LAC, RG 24, Vol 6177, file 1981-1, Vol 1, memorandum TS 19-81-3 (D/AMAP/P), entitled "NATO Medium Term Plan - Repricing - suggested Preliminary Action", from H.B. Godwin, A/C D/AMAP/P, to AMAP, dated 19 January 1951.

${ }^{62}$ DND, DHH, 193.009 (D 53), Box 7, May-Dec 50, Papers and Meetings, Chiefs of Staff Committee Meetings, Papers for October 1950, CJS 115/12, entitled "Progress Report No. 11 by the Canadian Joint Staff Washington", dated 20 October 1950, p. 6.
} 
completed in a manner acceptable to the US views unless these matters were excluded from the plan. ${ }^{63}$

The areas of disagreement between the two national planning staff included the provision of details on the command structure and arrangements, the division of responsibility between Canada and the United States regarding the level of support to be provided to the NATO regional forces, especially in regard to air defence, and the scheduling for the generation of forces following the commencement of hostilities. ${ }^{64}$ This difference of approach between the planning staffs appears reflective of an ongoing shift in priority for the Canadian military to a greater emphasis being placed on NATO, while a corresponding change had not taken place in the United States.

The air force's involvement with the NATO Short and Medium Term Plans demonstrated some maturity. The air force was not content with simply going along with American suggestions and attempts were made to define the Canadian position independently. The details of the Medium Term Plan also recall the RCAF's early postwar attempts to develop a multi-purpose force, as the reintroduction of bombers was included. But it is also noteworthy that this plan failed to identify any aircraft for close air support operations, which showed that within the NATO context, the air force did not intend to work closely with the Canadian Army. Perhaps the army's requirements under NATO would be provided by another country's forces under the concept of the integrated force. Nevertheless, the Canadian contribution to these plans demonstrated the continued

\footnotetext{
${ }^{63}$ DND, DHH, 193.009 (D 53), Box 7, Vol 96, CSC Meetings Papers for September 1950, Extract from Minutes of $474^{\text {th }}$ Meeting of Chiefs of Staff Committee, Held 26 September 1950, attachment HQTS.73050 Vol 3 (DMO\&P), entitled "Military Co-operation Committee Planning", from R. Rowley, Colonel, DMO\&P, to CGS, dated 19 September 1950, pp. 1-2.

${ }^{64}$ Ibid., p. 2.
} 
professional development of air force planners and showed how under NATO the RCAF continued to evolve into a Cold War force.

\section{Plan $G$}

In January 1950, the Minister of National Defence had approved a RCAF budget for the 1950/51 fiscal year in the amount of $\$ 169$ million and a personnel ceiling within one or two percent of 17,800. This was less than what was required for Plan F, which called for an annual budget of over $\$ 300$ million and around 25,000 service members. This caused the air force to re-scope its plans and a preliminary Plan G was developed by 20 February, 1950, based upon the approved budget and personnel limitations. The requirements identified in this initial Plan G, which included three F 86 squadrons and two CF 100 squadrons, later became known as the Target Position " $\mathrm{A}$ ". 65

Following the outbreak of the Korean Conflict and the July 1950 Cabinet Defence Committee direction to accelerate and enhance defence preparedness, the RCAF revised Plan G, developing Target Position "B". In doing so, a series of wartime commitments were articulated. These included the defence of Canada, which consisted of defence against air attack, protection of sea-lines of communication, and defence against airborne, amphibious and commando-type operations. There were also NATO-related roles, which were defined as provision of reinforcements overseas, and support and execution of strategic air offensive operations. ${ }^{66}$ Peacetime commitments were also augmented, including the addition of a training role for NATO and Royal Air Force personnel, and establishment and ongoing support for a Joint Canadian-American Arctic Weather

\footnotetext{
${ }^{65}$ DND, DHH, 181.004 (D 47), Plan "G” for the Royal Canadian Air Force, 1 September 1950 Revision, p. 1.
} 
Station. The RCAF was also responsible for continuing with tasks associated with the North West Staging Route, Goose Bay, photographic and survey work, and search and rescue operations. ${ }^{67}$

These responsibilities necessitated the creation of a larger, more operationally effective force, consisting of 16 Regular Force squadrons and 12 Auxiliary squadrons in place by 1 December 1953 (the Auxiliary squadrons were to be established at half strength). ${ }^{68}$ Unlike previous plans that phased developments over a number of years, Plan G sought to achieve the Target Position "B" goals as soon as possible. The air force was provided "considerable latitude" by the government to schedule and implement the required measures, in the expectation that this would help achieve the Plan G end-state quickly. ${ }^{69}$

Over a 43 month period, Plan $\mathrm{G}$ would result in more than a tripling of operational aircraft for the Regular RCAF, from 86 to 296 . Priority in this plan was given to the creation and fielding of an effective air defence force. Amongst the Regular Force units, there would be six F 86 squadrons and three CF 100 squadrons. The fighter squadrons were intended to be dispersed between St Hubert and Bagotville, Quebec, Uplands and North Bay, Ontario, Chatham, New Brunswick and Abbotsford, British Columbia. ${ }^{70}$ Three of the fighter squadrons were to be deployed overseas to the United

\footnotetext{
${ }^{66}$ Ibid., Section B, Blue Tab 1, p. 1.

${ }^{67}$ Ibid., Section B, Blue Tab 1, p. 2.

${ }^{68}$ Ibid., p. 2.

${ }^{69}$ Ibid., Section B, Blue Tab 1, p. 10.

${ }^{70}$ Ibid., Section B, Blue Tab 2, p. 3. The designation of Abbotsford as a west coast base may be found elsewhere in Plan G, at CAS Directive No. 4, as amended by Serial 84, 11 August 1950, entitled "Implementation of Increase and Acceleration of Plan "G", p. 2, which was included as part of Plan G.
} 
Kingdom by $1953 .^{71}$ In addition, the increase from a maritime patrol force of just two aircraft to three 12 aircraft squadrons was necessitated by the assessment that Soviet

Table 11: Plan G Regular RCAF Operational Aircraft Increases

\begin{tabular}{|c|c|c|c|c|c|c|c|c|}
\hline \multirow[t]{2}{*}{ Type of Sqn } & \multicolumn{2}{|c|}{$\begin{array}{l}\text { Position } \\
1 \text { Apr } 50\end{array}$} & \multicolumn{2}{|c|}{$\begin{array}{c}\text { Target } \\
1 \text { Nov } 51 \\
\end{array}$} & \multicolumn{2}{|c|}{$\begin{array}{c}\text { Target } \\
1 \text { Dec } 52 \\
\end{array}$} & \multicolumn{2}{|c|}{$\begin{array}{c}\text { Target } \\
1 \text { Dec 53 } \\
\end{array}$} \\
\hline & Sqns & $\mathrm{A} / \mathrm{C}$ & Sqns & $\mathrm{A} / \mathrm{C}$ & Sqns & $\mathrm{A} / \mathrm{C}$ & Sqns & $\mathrm{A} / \mathrm{C}$ \\
\hline Fighters & & & & & & & & \\
\hline Vampires & - & - & 1 & 25 & - & - & - & - \\
\hline $\begin{array}{l}\text { F } 86 \text { Day } \\
\text { Interceptors }\end{array}$ & 2 & 24 & 4 & 74 & 6 & 150 & 6 & 150 \\
\hline $\begin{array}{l}\text { CF } 100 \text { All } \\
\text { Weather } \\
\text { Fighter }\end{array}$ & - & - & - & - & 2 & 36 & 3 & 54 \\
\hline Maritime & & & & & & & & \\
\hline Long Range & 1 & 2 & 2 & 24 & 3 & 36 & 3 & 36 \\
\hline $\begin{array}{l}\text { Area } \\
\text { Reconnaissanc }\end{array}$ & & & & & & & & \\
\hline Long Range & 2 & 20 & 1 & 12 & 1 & 12 & 1 & 12 \\
\hline Transport & & & & & & & & \\
\hline Medium & 3 & 32 & 2 & 32 & 2 & 32 & 1 & 16 \\
\hline Heavy & - & - & - & - & - & - & 1 & 16 \\
\hline Long Range & 1 & 8 & 1 & 12 & 1 & 12 & 1 & 12 \\
\hline Bomber & - & - & - & - & - & - & - & - \\
\hline Total & 9 & 86 & 11 & 179 & 15 & 278 & 16 & 296 \\
\hline
\end{tabular}

${ }_{71}$ Ibid., Section B, Blue Tab 2, p. 4.
${ }^{72}$ Ibid., Section B, Blue Tab 3. 
submarine forces had grown and become more capable. ${ }^{73}$ Table 11 summarizes the number and composition of the operational squadrons.

The Auxiliary would also benefit under Plan G. As this plan was being written, the Auxiliary RCAF had 10 squadrons, with another two scheduled over the 1950/51 fiscal year (a second squadron for Toronto and another in a yet to be determined location). Eight of these squadrons (two each in Montreal and Toronto, Hamilton, London, Vancouver and the unspecified location) had an authorized strength of 265 and were to be equipped with six training aircraft and 12 fighters. There would also be two fighter-bomber squadrons (Winnipeg and Calgary), with the same equipment as the fighter squadrons and a strength of 287 and 278 respectively. Tactical bomber squadrons were located in Saskatoon and Edmonton, each provided with six training aircraft and eight tactical bombers. These units had an approved personnel ceiling of 422 each. Total Auxiliary strength was 3529 personnel, with 72 trainers, 120 fighters and 16 tactical bombers. ${ }^{74}$ To facilitate Auxiliary operations and training, around 1300 Regular RCAF personnel and civilians were placed in support. ${ }^{75}$

The mission of the two fighter-bomber and two tactical bomber squadrons from the Auxiliary force was to provide support to the Canadian Army in mobile striking force missions against enemy lodgements in Canada. Over the ensuing decade, these squadrons had difficulty maintaining staffing and training levels and in the end provided little effective operational support for army operations. Potential roles identified by Plan

\footnotetext{
${ }^{73}$ Ibid., Section A, Green Tab 2, p. 1.

${ }^{74}$ Ibid., Section C, Pink Tab 4.

${ }^{75}$ Ibid., Section C, Pink Tab 2, p. 6.
} 
G for the future but not yet allocated to the Auxiliary included strategic bombing, maritime and transport squadrons, and a women's reserve. ${ }^{76}$

As part of the build-up of the RCAF, the previously approved staffing level of around 17,800 service members had to be increased. Cabinet immediately approved an establishment of 24,920 for the air force and Plan G asked for this to be raised to 26,146. ${ }^{77}$ Plan G included the claim that recruitment would be assisted by improved personnel programmes, ${ }^{78}$ the details of which were not provided. Pay had increased somewhat from 1946. In 1950 , an untrained aircraftsman was offered $\$ 79$ monthly if living on an air base or $\$ 136$ if living off base (compared to $\$ 50$ and $\$ 95$ respectively in 1946). A Warrant Officer I Class received $\$ 180$ or $\$ 265$, depending on living arrangements (contrasted to $\$ 128$ or $\$ 188$ in 1946) and a Flying Officer earned between $\$ 195$ and $\$ 274$ ( $\$ 160$ and $\$ 220$ previously). ${ }^{79}$ Civilian jobs appeared to be better paying, with the average salary worker in Halifax getting $\$ 245.66$ monthly. In Vancouver, this rose to $\$ 282.33$ monthly. ${ }^{80}$ For new officers, the RCAF retained the short service commission programme, which ensured employment only for six years, but after which the air force could release any individual without penalty or pension rights. So job security with the RCAF was limited. Nor did the national unemployment rate suggest that there was a ready pool of recruits waiting for the air force. In 1946, the

\footnotetext{
${ }^{76}$ DND, DHH, 181.004 (D 47), Plan "G" for the Royal Canadian Air Force, 1 September 1950 Revision, Section C, Pink Tab 3, p. 5.

${ }_{78}^{77}$ Ibid., CAS Directive Number No. 4, p. 3.

${ }_{78}^{78}$ Ibid., Section B, Blue Tab 1, p. 5.

${ }^{79}$ Government of Canada, The Canada Year Book 1951, (Ottawa: King's Printer and Controller of Stationary, 1951), p. 1094.

${ }^{80}$ Ibid., pp. 675-676. For these civilian workers, pay was identified on a weekly basis and the monthly equivalent was determined by multiplying the weekly salary by 52 (for weeks in the year) and then dividing by 12 for the months in a year. The average weekly salary in Halifax was $\$ 56.69$ and in Vancouver, $\$ 65.15$.
} 
unemployment rate had been around 1.5 percent. By 1950, this rate was still low at around 2.5 percent. $^{81}$

In anticipation of the new personnel, additional recruitment centres, selection and manning depots, and training facilities were provided - and they were needed, as the air force encountered great success. The RCAF was soon preparing to train 500 navigators, 1810 pilots and 500 radio operators. Training space for another 800 navigators and 400 pilots per year from other NATO countries also had to be accommodated. ${ }^{82}$ An additional task was the training of hundreds of RCAF airmen per month plus, due to a decision to allow women to serve again, up to 300 women monthly for at least four months, beginning in February 1951. ${ }^{83}$ Between 31 March 1950 and 31 March 1951, the RCAF Regular and Auxiliary strength grew from a combined force of 19,643 to 25,566, representing over a 25 percent increase in one year. ${ }^{84}$ Given the problems with recruiting and low staffing levels in the immediate postwar period, this provided another sign of the changing fortunes of the air force.

Since pay and service terms provided little extra incentive from previously, the reasons for this recruiting success are unclear. The outbreak of the Korean Conflict likely attracted some people looking for adventure. Patriotism may have motivated others. The promise of new aircraft could have led some to join. Perhaps war weariness

\footnotetext{
${ }^{81}$ Dave Gower, "A Note on Canadian Unemployment Since 1921", Perspectives on Labour and Income, Autumn 1992 (Vol 4, No. 3, Article 3), p. 6.

${ }^{82}$ LAC, RG 24, Vol 5193, file 15-9-124, Part 1, Minutes of the $48^{\text {th }}$ Meeting of the Current Planning Committee Held in Room 2106, "A" Building, 1430 hrs, 12 January 1951, file number S15-9-124 (DOE) dated 15 January 1951.

${ }^{83}$ LAC, RG 24, Vol 5193, file 15-9-124, Part 1, Minutes of the $50^{\text {th }}$ Meeting of the Current Planning Committee Held in Room 2106, "A" Building, 1430 hrs, 23 January 1951, file number S15-9-124 (DOE), dated 24 January 1951.

${ }^{84}$ DND, DHH, 181.003 (D 5395), Addenda to RCAF Silver Jubilee Logbook, undated, pp. 2-3.
} 
after the Second World War had dissipated. Whatever the cause, the RCAF no longer had the personnel shortages that had plagued it for the five years after the end of the war.

The short term growth in the RCAF through Plan $G$ was the result of a confluence of a number of factors. Following the outbreak of the Korean Conflict, the threat environment had become more clearly perceived and the political leadership more readily accepted the requirement for larger defence forces. In addition to the air defence measures required under the Basic Security Plan, which were coming on line after an extended planning period, Canadian participation in NATO and support for the European allies provided ample opportunity for the RCAF to identify operational roles for the air force. Concurrent with this, production of F 86s and CF 100s was coming onto line, which allowed the RCAF to be equipped with modern jet technology. Plan G was another important and logical step in the growing professionalism demonstrated by the air force through planning.

\section{Planning for the Future}

The 1 September release of Plan G, which identified the requirement for 16 Regular Force and 12 Auxiliary squadrons, was a stepping stone to a larger force. As Plan $\mathrm{G}$ was being completed, the RCAF began work on its successor, Plan H. Following on from Plan G's approach of setting out Target Position "B", the next plan had Target "C". On 23 August 1950, the Plans Division developed "Plan G - 1 Sep 50 Revision Increase to 42 Squadrons", which detailed "the RCAF Requirements to build up to 30 Regular and 12 Auxiliary Squadrons by 1 Sep 53", consisting of a "Group of 9 Fighter- 
Interceptor Squadrons overseas ( 3 wings of $75 \mathrm{a} / \mathrm{c}$ each) completed by this date." ${ }^{85}$ This plan augmented the force structure described in Plan $\mathrm{G}$, in the form of an additional two fighter-interceptor squadrons for the air defence of Canada and three more fighterinterceptor squadrons as a reserve force for domestic, NATO or United Nations deployments. Another six fighter-interceptor squadrons were allocated for NATO within Europe, plus a divisional command structure to support these new squadrons plus those already assigned to this role in Plan G. ${ }^{86}$

This ambitious plan was approved in the following year as 'Plan ' $\mathrm{H}$ ' for the Royal Canadian Air Force - $1^{\text {st }}$ April, 1951 Edition". It obtained approval for 29 Regular Force squadrons and the previously established 12 Auxiliary Squadrons, for a total operational force of 41 squadrons. The target date to achieve this strength slid a little from the original planning document, to "July 1954 or sooner if possible" ${ }^{87}$ This expansion led to an RCAF establishment almost equalling the air force's Second World War overseas establishment of 48 squadrons and close to the Post War Organization Committee's proposal for 44 squadrons. This success demonstrated the progress made by air force planners and how the combination of political support and a palpable threat allowed the RCAF to build a large, capable Cold War air force.

As part of the work done in 1950 leading to Plan $\mathrm{H}$, a study was conducted of the most effective disposition of a fighter force within Canada to intercept enemy aircraft before they reached vital locations. It anticipated that the intruders would be able to attain a speed of at least 400 miles per hour at 40,000 feet. Radar sites were assumed to

\footnotetext{
${ }^{85}$ LAC, RG 24, Vol 6175, file 19-9-72, Vol 5, memorandum entitled "Plan G - 1 Sep 50 Revision Increase to 42 Squadrons", dated 23 August 1950, from H.B. Godwin, A/C, D/AMAP/P to AMAP, p. 1.

${ }^{86}$ Ibid., Appendix A.

${ }^{87}$ DND, DHH, 181.004 (D 48), Plan "H" for the Royal Canadian Air Force - 1 Apr 51 Edition, p. 2.
} 
have a 150 mile early warning radius and six fighter bases were dispersed across the country, in Bagotville and St Hubert, Quebec, North Bay and Uplands, Ontario, Chatham, New Brunswick, and Comox, British Columbia (which represented a change from Plan G, which designated Abbotsford). The CF 100s to be assigned to these bases could reach 40,000 feet within 8.2 minutes, covering between $60-95$ miles in such an ascent. Using an average time of 10 minutes to identify an intruder and to scramble an interceptor, when this was added to the eight minutes to attain altitude and allowing five minutes to press an attack, a total of about 23 minutes was required to effectively intercept a bomber. Given the likely speed of the bombers, it was calculated that the intruder would travel about 154 miles before being targeted. Since radar stations had a warning radius smaller than this (150 miles), any radar stations situated near or parallel to a target would have been ineffective, since an attacker would be able to cross the warning radius before being intercepted. ${ }^{88}$

This study identified priority targets within Canada $\left(1^{\text {st }}\right.$ priority - Windsor Montreal industrial corridor, $2^{\text {nd }}$ priority - Halifax and Sault Ste. Marie, $3^{\text {rd }}$ priority Vancouver, and $4^{\text {th }}$ priority - Goose Bay, the Alberta oilfields) and assessed the ability of aircraft stationed at the six bases, while supported by the current or intended radar stations, to intercept an attacker. It found that Bagotville was well situated to protect priority targets, but situated too far in advance of radar coverage to be effective. To fix this, additional radar stations were recommended to the north and northeast. While St Hubert was considered too close to Montreal, it also benefited from the amount of radar coverage to allow fighters to sortie early and engage an enemy before Montreal could be

\footnotetext{
${ }^{88}$ DND, DHH, 96/24 [096-105 Vol 6], entitled "The Deployment of an Expanded Fighter Force", by T.C. Parker, S/L, AOD/IF, dated 20 October 1950, pp. 1-2.
} 
reached. The radar coverage for Montreal was also found lacking and additional stations were suggested to the east and northeast. The same was found for North Bay and Comox, where the bases were well placed but two more radar sites were advised for each site. No fault was found with Upland's location or radar support. Chatham was considered poorly situated, providing no real protection for priority targets and lacking adequate radar coverage. ${ }^{89}$

To complete the fighter coverage for the priority targets, an additional four airbases were recommended. This included Anciene Lorette, to the east of Montreal, Mont Laurier or Lac-des-Ecorces, to the northwest of Montreal, London, Sault Ste Marie, and Halifax..$^{90}$ None of these were built, although a RCAF Station was developed in 1954 at Val-d'Or, Quebec, about 100 miles northwest of the proposed Mont Laurier location. This study shows that RCAF planning was a continuous process, often involving iterative steps whereby plans were revisited and attempts made to improve them over time. The system of mutually supportive fighter bases and radar sites had been under development since 1946 and even as the system was being implemented, there was an ongoing effort to improve the efficacy of it.

Concurrent with these developments, international consultation continued to provide an impetus for continued expansion of the Canadian military, with the RCAF being a major focal point. At a North Atlantic Council meeting in New York on 28 September 1950 , representatives from all 12 NATO nations formally agreed to take part in the integrated defence of Western Europe. On behalf of NATO, the Standing Group, the Military Committee and the Defence Committee were tasked with developing

\footnotetext{
${ }^{89}$ Ibid., pp. 2-3.

${ }^{90}$ Ibid., pp. 3-4.
} 
proposals providing recommendations on how and when each nation would contribute to this integrated force, with the expectations that each country would make commitments at a meeting on 28 October. ${ }^{91}$ Claxton later advised the Cabinet Defence Committee that

NATO was changing how nations planned. He noted that:

Previously, plans based on military requirements and agreed to by the planners of the countries concerned had not bound the Chiefs of Staff or the government. Cabinet had only to consider plans when it became necessary to take steps to implement them. Now, however, it was considered that when a country, planning with other countries, agreed on requirements, it was making at least a moral commitment to assume responsibility for its share of filling such requirements.

... The North Atlantic council ... had passed a resolution concerning the revision of the major force levels of the Medium Term Defence Plan in order to determine exactly what were [sic] the force levels required for defence of the West, based on military considerations alone. The Council had recommended " "that member governments upon being advised by the Council of the provisions of the revised Medium Term Defence Plan and the respective contributions required thereby, consider as a matter of urgency the acceptance of the Plan and the taking of such measures as may be necessary as rapidly as possible to meet the contributions required of them, on the assumption that the necessary complementary action in the fields of production and finance will be taken to provide the equipment required." This resolution in effect placed integrated force requirements in the category of moral commitments. Accordingly, force requirements to all intents and purposes had become statements of approved Armed Forces development programmes. ${ }^{92}$

Claxton went on to explain that Canada was the only NATO nation not requiring aid from the United States, which meant that the other NATO members could "put forward plans without any regard for their capacity to meet them financially. Fulfillment of these plans would be considered as dependent to a great extent on U.S. aid". Canada, on the

\footnotetext{
${ }^{91}$ LAC, RG 24, Vol 2748, Vol 5, The Sixty-Sixth Meeting of the Cabinet Defence Committee was Held in the Privy Council Chamber on Thursday, October $5^{\text {th }}, 1950$ at 10:30 a.m., pp. 1-5.

${ }_{92}$ LAC, RG 24, Vol 2748, Vol 5, The Sixty-Seventh Meeting of the Cabinet Defence Committee was Held in the Privy Council Chamber on Thursday, October $12^{\text {th }}, 1950$ at 2:30 p.m., pp. 2-3.
} 
other hand, had to be prepared to meet its alliance responsibilities entirely from its own resources. $^{93}$

Canada was involved in two NATO Regional Planning Groups. For the North Atlantic Ocean Regional Planning Group, Canada committed to provide 10 percent of the personnel and ships required for defensive operations to control sea and air lanes of communication in the Atlantic and northern North Sea. The United States assumed responsibility for 50 percent and the United Kingdom took on the other 40 percent. This was problematic, in that Canada had sufficient forces and equipment to satisfy only four percent of the responsibilities for this area of operations. For the Canada - United States Regional Planning Group, Canada was involved in the defence of national territory from air or airborne attack, as well as defending coastal waters, and supplying land and air reinforcements for the other regional groups on a rapid basis. ${ }^{94}$

These commitments were proving to be challenging for Canada from two perspectives. The requirements of the CUSRPG were difficult to define, as the United States recently had declined to approve the plans for North American air defence, without specifying any reason for this action. This had to be resolved in order for requirements to be identified, approved and provided. Secondly, the total financial liability the country would have as a result of the NATO commitments was unknown, but was believed to be considerably more than had been foreseen. As a first step to resolve these issues, the Chiefs of Staff were directed to hold discussions with their American counterparts to identify what the delay was with the CUSRPG plan. ${ }^{95}$

\footnotetext{
${ }^{93}$ Ibid., p. 3.

${ }^{94}$ Ibid.

${ }^{95}$ Ibid., pp. 4-7.
} 
Claxton directed the service chiefs to avoid sending any plans identifying equipment or manpower to NATO without approval from the Cabinet Defence Committee. ${ }^{96}$ To facilitate this, the Minister arranged for Cabinet to quickly review and approve plans from the services as part of the developmental process. The Chiefs of Staff were asked only to ensure that future plans were physically attainable (i.e., sufficient industrial capacity existed) before their submission. Plan costs would not be considered until after the completion of the programme. The services were also required to identify what capabilities could be designed as part of a NATO integrated force. Claxton specifically tasked the RCAF with providing three fighter squadrons for Europe by 1951 and up to another nine fighter squadrons by $1954 .^{97}$

This ministerial direction contained a number of important elements. It indicated that, for future military plans, budgetary restraint would not play the dominating role it had in the past - the cost of plans would be considered only afterwards. Secondly, fighter production and training would continue to be a primary focus of the RCAF. The commitment of up to 12 fighter squadrons for European deployment by 1954 surpassed the total fighter force for that period under Plan $\mathrm{G}$ and is further evidence of the increased importance of NATO to the RCAF.

The Cabinet Defence Committee met again on 1 December, at which time the full scope of NATO requirements became known. The Minister of National Defence indicated that nations were being asked to approve the NATO Medium Term Defence Plan. It appeared that other NATO members were willing to accept the requirements as identified in this document, since the United States would be providing assistance, but

\footnotetext{
${ }^{96}$ DND, DHH 193.009, (D 53) Box 7, Vol 96, CSC Meetings and Papers for September 1950, Extract from Minutes of Special Meeting of the Chiefs of Staff Committee, Held Thursday, 18 September 1950, p. 1.
} 
that Canada "could not accept any plan we could not carry out ourselves. As matters stood now the force tabulations put down for Canada in the Plan, especially for the Air Force, were well beyond Canadian capacity as presently organized for defence purposes." 98 The RCAF resources that were being solicited included 19 interceptor fighter squadrons, amounting to 475 aircraft, a reconnaissance squadron and two transport squadrons just for the CUSRPG. The Northern Atlantic Ocean Regional Planning Group sought three maritime squadrons. Another 12 squadrons were directed towards the integrated force. This represented another 12 squadrons in excess of current Canadian plans, amounting to about 500 additional aircraft. It was not known how these figures were arrived at by the NATO Standing Group, but it was understood by Claxton that the American contribution to the integrated force had dropped from 2000 aircraft down to 1000 overnight. ${ }^{99}$ General Foulkes had protested the inclusion of these forces in NATO plans to the US Chairman of the Joint Chiefs of Staff, General Omar Bradley, at a recent Military Committee meeting, for which he received an apology for the Standing Group having not consulted Canada first. In fact, Foulkes noted that "Canada was the only country which had been faced with such a decision on such short notice and without prior consultation". 100

Despite these concerns, the Cabinet Defence Committee did not out of hand dismiss this NATO request. Discussion resolved that, with increased aircraft production, the fighter shortfall could be satisfied within two years. The committee took this under advisement and asked the Chief of the General Staff to communicate to the US Joint

\footnotetext{
${ }^{97}$ Ibid., p. 2. Plan G actually indicated that the first three overseas squadrons were to be deployed by 1953 .

${ }^{98}$ LAC, RG 24, Vol 2748, Vol 5, The Sixty-Eighth Meeting of the Cabinet Defence Committee was held in the Privy Council Chamber on Friday, December 1, 1950, at 10:30 a.m., p. 3.

${ }^{99}$ Ibid., pp. 4-5.
} 
Chiefs of Staff that Canada's NATO commitments must be kept at a level the country was capable of sustaining. ${ }^{101}$ That this protest was lodged directly with the American military and not NATO demonstrated where the authority and leadership within the alliance rested.

At the final Cabinet Defence Committee meeting of the year, the Minister of National Defence briefed his colleagues on a comparative analysis of the Canadian and American contributions towards defence. The United States was spending $\$ 22.5$ billion for 1951, representing 9.5 percent of national income and 47.2 percent of all government spending. This worked out to $\$ 148$ being spent on defence per capita. Canada's commitment for the next year was $\$ 700$ million, which consisted of 5.7 percent of national income and 29.6 percent of government spending. Per capita spending on defence amounted to $\$ 51.40$. Out of every 1000 Americans, 23 were serving in uniform, while in Canada it was 4.5 per $1000 .^{102}$ Claxton observed that, even if the threat of major conflict was exaggerated, it appeared true that the odds of this occurring had increased over the past six months. With this in mind, while the committee might be reluctant to endorse a high level of defence spending, the "greatly expanded U.S. defence measures would make Canada's position increasingly difficult to justify." ${ }^{103}$ Therefore, Claxton recommended that the service programs be supported in order to provide for Canadian security, continued support to Korean operations, the contribution of a Brigade Group and fighter squadrons to the NATO Integrated Force, and improvements to military

\footnotetext{
${ }^{100}$ Ibid., p. 4.

${ }^{101}$ Ibid., pp. 6-8.

${ }^{102}$ LAC, RG 24, Vol 2748, Vol 5, The Sixty-Ninth Meeting of the Cabinet Defence Committee was Held in the Privy Council Chamber on Thursday, December $28^{\text {th }}$, 1950, at 11:00 a.m., p. 2.

${ }^{103}$ Ibid.
} 
training systems. ${ }^{104}$ The cost of these measures during the 1951-52 fiscal year would be between $\$ 940$ million and $\$ 1.04$ billion.

Claxton indicated that accelerated production of aircraft engines and frames would allow the air force to meet its responsibilities domestically and as part of the Integrated Force. Another attempt was made to provide an operational role for the Auxiliary, which was tasked with providing ten of the 19 fighter squadrons for domestic defence. ${ }^{105}$ The Cabinet Defence Committee endorsed these measures, which became the basis for the previously described Plan $\mathrm{H}$.

Canada was sharing the burden for common defence measures, but there were limits to how far it would go. The following year, the Chiefs of Air Staff for the United Kingdom, France, the United States and Canada met to discuss how to close the gap between the Medium Term Defence Plan requirements and the actions the various governments had taken to date. At this meeting, Lieutenant-General Norstad, an American serving as the Commander-in-Chief of the Central European Air Force, tabled a proposal on how to make up the shortfalls. His proposal included additional requirements from Canada, asking for a total commitment of 12 fighter squadrons consisting of 300 aircraft and another 490 fighters in reserve, 12 light bomber squadrons with 192 first-line aircraft and another 172 bombers in reserve, and one long-range transport squadron with 16 aircraft. Canada was asked to produce aircraft for other NATO nations, in the amount of $140 \mathrm{~F} 86 \mathrm{~s}$ in 1952 , another $450 \mathrm{~F} 86 \mathrm{~s}$ and $49 \mathrm{CF} 100 \mathrm{~s}$ in 1953, and $1220 \mathrm{~F} 86 \mathrm{~s}$ and $58 \mathrm{CF} 100 \mathrm{~s}$ in 1954, plus 400 Harvard trainers and $217 \mathrm{~T} 33$ jet

\footnotetext{
${ }^{104}$ Ibid., pp. 2-3.

${ }^{105}$ Ibid., pp. 6-8.
} 
trainers. ${ }^{106}$ Prime Minister St. Laurent intervened, indicating that "no additional commitments could be undertaken" and that Canada's defence effort was already as large as it would be, in the absence of the outbreak of all out war. ${ }^{107}$ Canada was willing to take part in collective security, but there were limits to how far it would go.

Douglas Bland has described this period as belonging to "The Command Era", which was "characterized by command authority, military concepts of decision-making and administration ... and a reliance on subjectivity based on experience."108 This approach led to "hedging" as a management philosophy, resulting in militarily efficient, but fiscally inefficient, decisions. For Bland, planning at this time "reflected the command theories of administration, the specific responsibilities of individuals, and a traditional military approach of interpreting objectives into pragmatic plans and requirements. ${ }^{" 109} \mathrm{He}$ also argued that Ministers of National Defence during the Command Era provided policy guidance that shaped defence administration, allowing a "continual focus on operational capabilities and clearly defined objectives within the services". As a result of this focus, military leaders were able to exert a measure of control over defence policy. ${ }^{110}$

While there are reasons to agree largely with the general thrust of these comments by Bland, he downplayed some important aspects. Bland described Claxton as a confident activist, who oversaw change and was sure of his own ideas and perceptions. ${ }^{111}$ This is true, but it does not give sufficient credit to the role of Prime Minister St. Laurent,

\footnotetext{
${ }^{106}$ LAC, RG 24, Vol 2748, Vol 5, The Seventy-Fourth Meeting of the Cabinet Defence Committee was Held in the Privy Council Chamber on Tuesday, May 29 $9^{\text {th }}, 1951$, at 11:00 a.m., pp. 2-3.

${ }^{107}$ Ibid, p. 7.

${ }^{108}$ Douglas Bland, The Administration of Defence Policy in Canada, 1947 to 1985 (Kingston: Ronald P. Frye \& Company, 1987), p. 5.

${ }^{109}$ Ibid.

${ }^{110}$ Ibid., p. 6.
} 
who was both an advocate for a major defence role for Canada and the final arbiter capable of defining when the country would do no more. Similarly, Bland did not acknowledge the role of other government departments in determining defence policy; during the late 1940s and early 1950s, Secretary of State for External Affairs Lester Pearson clearly supported Canada playing a major military role on the world stage. Because of this level of support within Cabinet, Canadian political-military relations during this period were highly cordial and the armed services, especially the RCAF, enjoyed significant support. While Bland suggested that military planners during the Command Era tended to "hedge" on the side of caution and large expenditures, this approach also was taken by the political elite after the Korean Conflict broke out and NATO expansion began in earnest. The government provided direction to the military through the development of defence policy and any increased role for the military in this area was tacitly sanctioned by the government.

\section{Conclusion}

The combination of a requirement for continental air defence and the expanded role for NATO that evolved following the outbreak of the Korean Conflict allowed the RCAF to obtain the political and financial support necessary for substantial growth. The 41 squadron force approved as part of Plan $\mathrm{H}$ showed that RCAF planners were encountering a high level of success in advancing air force interests. The Millett, Murray and Watman methodology argues that political effectiveness is achieved when a military force, in this case the RCAF, is able to convince political leadership of the requirement to dedicate financial resources. The air force had clearly achieved this, as it received more

${ }^{111}$ Ibid., p. 95. 
funds than the other services. ${ }^{112}$ The RCAF had been able to convince the government that such measures were required to ensure the security of the nation and NATO. Millett, Murray and Watman also describe strategic effectiveness as being attained through a reciprocal process of negotiations with the government, leading to military strategic alternatives influencing political intentions. The evolutionary nature of the negotiations that led to the substantial RCAF contribution to NATO is an example of this. The government was a willing partner in this process - St. Laurent, Claxton and the rest of the Cabinet Defence Committee supported Canada's participation in NATO for a range of political and strategic reasons and not simply because the services had convinced them of this requirement. The approval of the 41 squadron air force is another example of strategic effectiveness, as the government's overall strategic goal of military stability within Canada and the western democracies was being achieved. The air force's size and structure was a physical manifestation of this strategy. Yet this state of affairs was unlikely to last forever. An early indication that change was forthcoming was the decision in May 1951 by St. Laurent, who had supported a series of increases to the military, to deny further air force contributions to NATO in the form of a large bomber force.

Janowitz and Abrahamsson have argued that the military is not apolitical and that it functions as an interest group, defining and protecting its self-interests. The civilmilitary interaction during 1950 and early 1951 bore this out, as the RCAF successfully pursued an enhanced role in the defence of Canada and within NATO. However, an example of excessive military self-advocacy was provided through the Norstad proposal,

\footnotetext{
${ }^{112}$ As detailed in Table 7, in 1951 the RCAF received more than $10 \%$ more than the army and more than twice the budget allocation of the navy. In the two years that followed, the air force obtained a budget
} 
which would have seen a marked increase in the RCAF well beyond the approved 41 squadrons through the addition of a large bomber force to support NATO. This militarygenerated proposal also provides a clear example of why Huntington's prescriptive approach to civil-military relations bears re-examination. According to Huntington, the professional military loyally adheres to political direction and provides impartial advice. Norstad and several chiefs of air staff, including Canada's Curtis, essentially sought to double the RCAF's contribution to NATO, plus provide another 2534 aircraft to other NATO nations. This was neither apolitical nor impartial. NATO's air forces, including the RCAF, were engaged in excessively promoting their organizational interests and not the interests of Canada.

The RCAF continued planning, building and fielding a force throughout the rest of the decade. But it never enjoyed another period of such significant growth and political support as had occurred in 1950 and early 1951 following the outbreak of the Korean Conflict. In addition to implementing the plans that had been approved, a major air force focus for the rest of the 1950s was defending the progress that had been achieved. Related to this was the ongoing attempt to introduce new technology, best represented by the subsequent development of the CF 105, the Avro Arrow. The production problems and costs of the Arrow proved too much for the government and the air force had to give up on it before it could be introduced into service. ${ }^{113}$ Even if the Arrow had reached operational service, the changing threat, in the form of

\footnotetext{
share roughly equivalent to the combined resources dedicated to the other two services.

${ }^{113}$ Non-academic works such as Craig Stewart's Shutting Down the National Dream: A.V. Roe and the Tragedy of the Avro Arrow (Toronto: McGraw-Hill Ryerson Ltd, 1988) and The Life and Times of Crawford Gordon and the Avro Arrow: An Arrow Through the Heart (Toronto: McGraw-Hill Ryerson Let, 1998) provide a popular rendition of how the Arrow was cancelled. A more balanced representation may be found at Russell Isinger, "The Avro Canada CF-105 Arrow Programme: Decision and Determinants", an unpublished MA thesis in Political Studies, University of Saskatchewan, 1997.
} 
intercontinental ballistic missiles, and the expanding fiscal demands would cause the government to begin to reassess the requirement for a large fighter force. The planning and preparation for Plans $\mathrm{G}$ and $\mathrm{H}$ represented the high point for the postwar RCAF and as such are the best evidence of the level of competency and professionalism achieved by air force planners. It was through these documents that the RCAF created the environment and means for fielding a large, combat-capable force. Although this air force was to have a preponderance of fighter-interceptors, it did retain the ability to fulfil a wide range of roles. This included reconnaissance, mapping and charting, transport, tactical support and a limited light bombing capability. The RCAF had achieved its postwar goal of having a Cold War multi-purpose force. 


\section{CONCLUSION:}

\section{THE MAKING OF A COLD WAR AIR FORCE}

The RCAF's ability to develop and implement plans markedly evolved between 1944 and 1950. This, combined with increased professionalism, contributed to the unparalleled expansion of the peacetime air force and an enhanced RCAF role in defending Canadian territory and interests.

As the end of the Second World War approached, the RCAF appointed an ad hoc committee, the Post War Organization Committee, to develop a postwar plan for a large, multipurpose organization, capable of a wide variety of missions. This committee failed to consult widely, received little political direction and did not take into account considerations external to the air force. When the government focused on civil sector initiatives immediately after the war, the services were subjected to fiscal and manpower resource constraints. This initial air force attempt at postwar planning was an utter failure, as virtually none of it was implemented.

Plans B and E followed for the RCAF, both of which limited development of professional attributes and skills within the air force. With few personnel and aircraft, the RCAF had no combat capability and was incapable of defending Canada from attack. But the air force was learning from its mistakes and improved its planning processes and practices over time. In 1947, full time staff was assigned to planning and a senior position responsible for planning, the Air Member for Air Plans, was created. The formation of a multi-disciplinary body, the Current Plans and Estimates Committee, allowed a wide range of factors to be addressed during the course of plan development. Experience was gained through bilateral negotiations with the United States, leading to 
the Basic Security Plan. The adoption of multi-year plans provided the means of managing and phasing major procurement over a number of years. The air force became better at contingency planning, thereby ensuring that a range of options was provided to political leadership for consideration.

As air force planning skills evolved, so too did the fortunes of the RCAF. Plan F resurrected some combat capability and focused the RCAF on air defence. Plans G and $\mathrm{H}$ identified the requirement for a large fighter-interceptor force. Once fielded, the air force squadrons provided the means of response to the Soviet bomber threat. The professional skill nurtured over time and shown in the later plans allowed the air force to succeed as an organization.

After the war, the Soviet Union increasingly posed a threat to western democracies and technological developments, including long range aircraft and atomic weapons, resulted in the risk of serious attack to North America. This provided much of the impetus to the changes that took place. Public and political anti-communist sentiment was present and supported Canadian participation in defensive alliances as a countermeasure to the threat. Wartime defence cooperation between Canada and the United States was renewed under PJBD Recommendation 35 and the Military Cooperation Committee developed the Basic Security Plan to provide protection from the Soviet air threat. The air force had a lead role in the defensive measures identified and the development of a fighter-interceptor force ensued. With this, a fundamental change occurred in the form and function of the RCAF. No longer would the air force be tasked with the prewar civil air operations or wartime strategic bombing missions. Later on, with the formation of NATO and the creation of the Integrated Force, the RCAF focused 
further on fighter-interceptors. Through planning and professionalism, the postwar RCAF was shaped to take part in the Cold War.

A consideration related to the improved professionalism within the air force was a change in its leadership. As Chief of the Air Staff, Wilf Curtis was better suited to oversee the changes in the RCAF than his predecessor, Robert Leckie. Curtis was able to work well with the Minister to further air force interests, while at the same time maintaining a reasonable working relationship with the other service chiefs. Curtis had a vision for a fighter-interceptor force with aircraft built in Canada, and he was able to see it through. The result was the creation of a large peacetime RCAF and the growth in aircraft manufacturing within Canada. Curtis also benefited from the assistance of a strong supporting cast, including two future Chiefs of the Air Staff, Roy Slemon and C.R. Dunlap.

Under Prime Minister Mackenzie King, the postwar government concentrated on reviving the postwar Canadian economy and the development of social programmes. The prime minister's lack of trust in the ability of Colin Gibson, as Minister of National Defence for Air, to constrain air force spending contributed to the appointment of Brooke Claxton. An adept politician, Claxton provided political leadership to the military and defined the roles of the services in a 1947 policy statement. His decision to allow the service chiefs to oversee the development of bilateral defence plans with the United States and limit the political role to plan approval and financing helped foster good civilmilitary relations and provided the opportunity for military staff to improve their planning skills. The arrival of two internationalists in positions of authority, Louis St. Laurent as Prime Minister and Lester Pearson as Secretary of State for External Affairs, 
facilitated Canadian participation in collective security through NATO. Between the Basic Security Plan and various NATO plans, the RCAF had the opportunity to develop planning skills and to grow as an organization.

According to Millett, Murray and Watman, political effectiveness relates to being able to convince political leadership that one group's needs are more important than those of others. Through the threat assessments, politicians were sensitized to the need for air defence and the RCAF was able to gain the cooperation of the government for increased funding. The air force identified the requirement for a fighter-interceptor force supported by radar, which required significant financial support from the government. A measure of Curtis' effectiveness was his ability to obtain this support and may be seen in terms of relative budgetary share. Traditionally the Canadian Army had received more funds than the other services, but by the early 1950 s, the RCAF was the recipient of almost 50 percent of the total defence budget, while the army was reduced to around 34 percent and the navy obtained only around 17 percent (see Table 7). The air force, for the first time, won the battle for budget share.

The RCAF during this period did a good job of integrating technology with its operational plans. As technology changed, plans would be amended to best address the Soviet threat. For example, as radar became more capable and aircraft capabilities improved, the air force reconsidered where to situate radar sites and interceptor stations in order to provide for the air defence of Canada. The air force developed operational specifications for a range of aircraft, including the CF 100 . This aircraft played a major role in Canada's air defence and provided industrial benefits to the Canadian economy. The RCAF plans sponsored a number of initiatives in other defence industries, including 
such diverse areas as communications, radar, air engine production and weaponry. For example, Plan G led to development of telecommunications, air weapons and air navigation aids. This ability to exploit technology to advantage was another sign of the professionalism that had developed within the air force.

The postwar RCAF did encounter significant difficulties in integrating technology with the Auxiliary force. Auxiliary personnel had problems developing and retaining the skills needed to maintain their aircraft, especially in relation to jet propulsion technology. Air force plans reflected this over time, with Plan B in 1946 identifying the Auxiliary as primarily responsible for the air defence of Canada; by Plan G in 1950, the Auxiliary was no longer expected to have operationally ready forces until 90 days after mobilization. While Plan H held hope that the Auxiliary would become more operationally proficient, as demonstrated by ten fighter-interceptor squadrons allocated for the Auxiliary, this proved unattainable. By the end of the 1950s, the Auxiliary was equipped with old technology, including the Expeditor, a light air transport aircraft, and had no meaningful operational role. ${ }^{1}$

For Millett, Murray and Watman, strategic effectiveness relates to the iterative process of negotiations between the political leadership and the military. The reciprocal dialogue requires political goals to inform strategy, but the development of strategic alternatives by the military also help to shape political intentions. Analysis of strategic effectiveness focuses on this reciprocity. Initially, the air force had little success in negotiating with the government - the postwar air force went through a series of government directed reductions between 1945 and 1949. On several occasions, approved 
plans later had to be cut back (Plans B, E and F each experienced this). But this was to change. By the early 1950 s, negotiations between the air force and the government became more reciprocal in nature, which contributed to the government's decision to contribute significantly to the NATO Integrated Force. This collaborative approach was demonstrated in late 1950 by Claxton's willingness to take defence proposals to Cabinet despite concerns that the nature of the threat was exaggerated. He understood that the international security environment was deteriorating and that additional defensive measures were required as a result.

A number of factors contributed to this increased ability of the RCAF to influence political leadership. The changed strategic environment and technological developments required defensive forces to be "in being" and able to respond as threats emerged. Politicians had been sensitized to this with the postwar establishment of collaborative Canada-United States intelligence gathering and reporting. This ensured that Canada's political elite was kept abreast of developments posing a danger to national security and air force plans focused on addressing these threats. In December, 1950, the Cabinet Defence Committee also became aware that, in relative terms, Canada was spending much less on defence than the United States. These considerations combined to contribute to a positive political environment for increased defence spending and the air force benefited. The RCAF had the good fortune of being the service best suited to respond to the evolving threats, and planning and professionalism allowed them to exploit this advantage. The air force also effectively changed its operational plans as the strategic environment shifted. As the air threat to North America became apparent, air

\footnotetext{
${ }^{1}$ For more details on this, see Sandy Babcock, "Withered on the Vine: The Postwar RCAF Auxiliary", in Yves Tremblay, ed., Canadian Military History Since the $17^{\text {th }}$ Century: Proceedings of the Canadian
} 
defence measures were identified in the Basic Security Plan. Later on, the RCAF became involved in North Atlantic alliance planning and, following the outbreak of the Korean Conflict, planned to send squadrons to take part in NATO's Integrated Force.

Janowitz contended that the military required political-social insights to deal with political-military issues and the security environment. Under Curtis, the air force was pragmatic and exercised caution about what was contained in its plans, ensuring that proposals to the government where politically palatable. Claxton and St. Laurent supported a defence relationship with the United States, and air force plans emphasized this. The air force sought to standardize with American equipment as a means of encouraging this relationship. Political leadership wanted Canada to play a role in NATO and the RCAF took advantage of the opportunity to further expand its fighter-interceptor force. Huntington saw military professionalism as apolitical in nature, duty bound to provide impartial advice to political leadership and then to following direction regardless of agreement. Janowitz and Abrahamsson believed that military professionalism led to vested interests and competition for scarce assets. Foulkes, as Chief of the General Staff, repeatedly struggled to change the government's focus from the air force, but he was unsuccessful. This inter-service rivalry remained within reasonable boundaries for a number of years, but it would later become public. ${ }^{2}$ For its part, the air force treated tactical support operations in support of the army as a low priority task, giving these to the Auxiliary force to address with old aircraft. The RCAF preferred to focus on mandates for which it had the operational lead, such as the interceptor role, and this was

Military History Conference, Ottawa, 5-9 May 2000 (Ottawa: Directorate of History and Heritage, 2000). ${ }^{2}$ See Guy Simonds, "Where We've Gone Wrong on Defence", Maclean's, 23 June 1956, for a criticism of the government's expenditures on air defence. Also see Charles Foulkes, "Our Defence Dollars are Being Wasted", The Star Weekly Magazine, 14 October 1961. 
reflected in the various plans. The RCAF defined and defended organizational interests and won the battle for budget share against the army and navy. Under Huntington's prescriptive model, Norstad and fellow air force leaders would not have volunteered advice that was so skewed in favour of the air force. Janowitz and Abrahamsson expected this kind of behaviour.

The Janowitz and Abrahamsson sociological approach to examining decisionmaking within the RCAF was more useful than Huntington's political science approach. Huntington's contention that the military should be apolitical certainly has its appeal, but the pragmatism of Janowitz appears more closely aligned with how the RCAF went about planning and operating. The air force had organizational interests and it took every opportunity to pursue these, which directly affected how and what decisions were made.

The Millett, Murray and Watman methodology has some limitations. While assessing the relationship between military intentions and results has its merit, there are often considerations beyond the control of the military that influence the outcome. For instance, in the immediate postwar period, the Canadian military did not enjoy much political support. The government focused on a range of social issues and limited funds were available for national defence. The RCAF hoped to retain a large, multi-purpose air force after the war, but this could not be achieved because of the level of political and economic support received. This gap between air force intentions and the end results had little to do with air force effectiveness.

After a series of initial setbacks, the air force developed an effective planning process that allowed it to take advantage of the opportunities presented by the postwar strategic environment. Plan development was assisted by the professional skills 
developed within the air force, so that leadership and planners learned and adapted from their experiences. While there were a range of factors that influenced how the air force evolved, including the strategic environment, technological developments, leadership and political direction, this thesis has concentrated on two. Planning and professionalism were critical in the making of a large Cold War air force that contributed to domestic, North American and NATO security. 


\section{BIBLIOGRAPHY}

\section{Primary Sources}

\section{Government Records and Manuscript Collection}

Library and Archives Canada:

Department of National Defence Records

Cabinet Defence Committee Records

Cabinet Conclusions

Privy Council Office Records

W.L. Mackenzie King Papers.

Air Marshal Robert Leckie Papers

Air Marshal W.A. Curtis Papers

Brooke Claxton Papers

Department of National Defence, Directorate of History and Heritage:

Air Council Papers

Chiefs of Staff Committee Papers

Raymont Papers

\section{Government Publications}

Canada. Careers in the Armed Forces - A Message from the Chiefs of Staff, Navy, Army, Air Force and the Director General Defence Research. Ottawa, King's Printer and Controller of Stationary, 1946.

Canada. Canada's Defence - Statement by Hon Brooke Claxton, MND. Ottawa, DND, 1947.

Canada. Canada's Defence Programme, 1949-1950. Ottawa, DND, 1949.

Canada. Postwar Plan for the Royal Canadian Air Force (Plan B). Ottawa, DND, 1946. 
Canada. Report to the Prime Minister - A Paper Prepared for the Minister of National Defence - Bringing the Canadian Armed Forces into the Twenty-First Century. Ottawa, DND, 1997.

Canada. Royal Canadian Air Force Plan E. Ottawa, DND, 1947.

Canada. Royal Canadian Air Force Plan F. Ottawa, DND, 1949.

Canada. Royal Canadian Air Force Plan G. Ottawa, DND, 1950.

Canada. Royal Canadian Air Force Plan H. Ottawa, DND, 1951.

Canada. The Canada Year Book 1947. Ottawa, King's Printer and Controller of Stationary, 1947.

Canada. The Canada Year Book 1951. Ottawa, King's Printer and Controller of Stationary, 1951.

United States. American Relations with the Soviet Union. N.p, n.p, 24 September 1946.

\section{Secondary Sources}

Abrahamsson, Bengt. Military Professionalization and Political Power. Beverly Hills, Sage Publications, 1972.

Arkin, William, M. Code Names: Deciphering US Military Plans, Programs, and Operations in the 9/11 World. Hanover, Hew Hampshire, Steerforth Press, 2005.

Arnold, General Henry H. Global Mission. New York, Harper, 1949.

Armitage, M.J. and Mason, R.A. Air Power in the Nuclear Age. Chicago, University of Illinois Press, 1983.

Andrewski, Stanislav. Military Organization and Society. Berkley, University of California Press, 1971.

Berg, Glen. Scrambling for Dollars: Resource Allocation and the Politics of Canadian Fighter Aircraft Procurement, 1943-1983. An unpublished MA thesis in War Studies, Royal Military College of Canada, Kingston, 1983.

Bercuson, David. True Patriot: The Life of Brooke Claxton, 1898-1969. Toronto, University of Toronto Press, 1993.

Oxford University Press, 1992.

and J.L. Granatstein, Dictionary of Canadian Military History. Toronto, 
Birkler, John L. et al. Gaining New Military Capability: An Experiment in Concept Development. Santa Monica, California, RAND, 1998.

Bland, Douglas. The Administration of Defence Policy in Canada, 1947 to 1985. Kingston, Ronald P. Frye \& Company, 1987. , ed. Canada's National Defence - Volume 1, Defence Policy. School of Policy Studies, McGill-Queen's University Press, Kingston, 1997.

Bland, Lieutenant-Colonel D.L. "The Armed Forces Council and the Defence Policy Process", Canadian Defence Quarterly, Vol. 16, No. 3, Winter 1986-87, 26-30.

Bland, Douglas L. "Controlling the Defense Policy Process in Canada: White Papers on Defense and Bureaucratic Politics in the Department of National Defence", Defense Analysis, Vol. 5, No. 1, 3-17.

Boll, Michael M. National Security Planning: Roosevelt through Reagan. Lexington, Kentucky, University Press of Kentucky, 1988.

Borowski, Harry R., ed. Military Planning in the Twentieth Century: Proceedings of the Eleventh Military History Symposium. Washington, D.C., Office of Air Force History, 1984.

Bothwell, Robert and Kilbourn, William. C.D. Howe: A Biography. Toronto, McClelland and Stewart, 1979.

Brodie, Bernard. Strategy in the Missile Age. Princeton, Princeton University Press, 1959. . War \& Politics. New York, Macmillan, 1973.

Brulotte, Bryan. Visions of Grandeur: Planning for the Canadian Post-war Army, 19441947. An unpublished MA thesis in History, Carleton University, 1991.

Bryant, Arthur. The Turn of the Tide - A History of the War Years Based on the Diaries of Field-Marshal Lord Alanbrooke, Chief of the Imperial General Staff, 1939-1943. New York, Doubleday \& Company, 1957.

Bucholz, Arden. Moltke, Schlieffen, and Prussian War Planning. New York, Berg, 1991.

Burk, James. "Expertise, Jurisdiction, and Legitimacy of the Military Profession", Addendum 1 to Annex C, Professions of Arms Working Group, 29 November 2001, presented to the Inter-University Seminar on Armed Forces and Society, 19-21 October 2001, Baltimore, Maryland, 1-40. 
Byers, Roddick Beaumont. Canada and Defence Industrial Preparedness: Options and Prospects. Toronto, York University Press, 1987.

Byers, R.B. "Perceptions of Parliamentary Surveillance on the Executive: The Case of Canadian Defence Policy", Canadian Journal of Political Science, Vol. V, 1972, 234250.

. "The Nature of Military Professionalism." Canadian Military

Professionalism: The Search for Identity, Wellesley Paper 2 (February 1973), edited by R.B. Byers and Colin S. Gray, Canadian Institute of International Affairs, 7-25.

Call, Steven Charles. A People's Air Force: Air Power and American Popular Culture, 1945-1965. An unpublished $\mathrm{PhD}$ thesis in History, The Ohio State University, 1997.

Churchill, Winston S. The Second World War - The Hinge of Fate, Volume 4. Boston, Houghton Mifflin Company, 1983.

Claxton, B. "The Place of Canada in Postwar Organization." Canadian Journal of Economics and Political Science, Vol 10, No. 4, November 1944, 409-421.

March 1948, 1-5.

"The Coordination of Canada's Defence Forces." Canadian Army Journal,

Clearwater, John. Canadian Nuclear Weapons: The Untold Story of Canada's Cold War Arsenal. Toronto, Dundurn Press, 1998.

. U.S. Nuclear Weapons in Canada. Toronto, Dundurn Press, 1999.

Collins, John M. U.S. Defense Planning: A Critique. Boulder, Colorado, Westview Press, 1982.

Conant, Melvin. "Political Aspects of the Strategic Force." RCAF Staff College Journal, 1960, 51-56.

- "Canada and Continental Defence: An American View." International

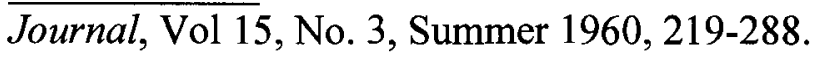

. The Long Polar Watch: Canada and the Defense of North America. New York, Harper, 1962.

Corn, Joseph J. The Winged Gospel: America's Romance with Aviation, 1900-1950. New York, Oxford University Press, 1983. 
Craddock, Percy. Know Your Enemy: How the Joint Intelligence Committee Saw the World. London, John Murray, 2002.

Craig, Campbell and Radchenko, Sergey. The Atom Bomb and the Origins of the Cold War. New Haven, Yale University Press, 2008.

Cuff, R.D. and J.L. Granatstein. Canadian-American Relations in Wartime: From the Great War to the Cold War. Toronto, Hakkert, 1975.

Davis, Lynn E et al. Hurricane Katrina-Lessons for Army Planning and Operations. Santa Monica, California: RAND, 2007.

Davis, Paul, K. Effects-Based Operations: A Grand Challenge for the Analytical Community. Santa Monica, California, RAND, 2001.

de Hoop Scheffer, Japp. "NATO and the EU: Time for a New Chapter" (Berlin: www.europarl.europa.eu/meetdocs/2004_2009/documents/

dv/280/280220/28022007speechsecrgl_berlin29012007_en.pdf, 29 January 2007)

Dewitt, David and Leyton-Brown, David. Canada's International Security Policy. Scarborough, Prentice Hill Canada, 1995.

Directorate of Land Strategic Concepts. Future Force: Concepts for Future Army Capabilities. Kingston, Ontario, Directorate of Land Strategic Concepts, 2003.

Donaghy, Greg, ed. Canada and the Early Cold War, 1943-1957. N.p., Department of Foreign Affairs and International Trade, 1998.

Douglas, W.A.B. The Creation of a National Air Force: The Official History of the Royal Canadian Air Force, Volume II. Toronto, University of Toronto Press, 1986.

- "Preparing for Different Wars: Canadian Naval and Air Force Relationship, 1918-1939." In New Interpretations in Naval History: Selected Papers from the Tenth Naval History Symposium held at the United States Naval Academy, 1113 September 1991. Jack Sweetman, ed. Annapolis, MD, Naval Institute Press, 1993, 309-332.

Eayrs, James. Northern Approaches: Canada and the Search for Peace. Toronto, Macmillan, 1961. of Toronto Press, 1972.

. In Defence of Canada: Peacemaking and Deterrence. Toronto, University . In Defence of Canada: Growing Up Allied. Toronto, University of

Toronto Press, 1980. 
. In Defence of Canada: Indochina - Roots of Complicity. Toronto, University of Toronto Press, 1983.

Echevarria II, Antulio J., "War, Politics and RMA: The Legacy of Clausewitz". In Joint Force Quarterly, Winter 1995-96, pp. 76-80.

English, John. Shadow of Heaven: The Life of Lester Pearson, Volume One: $1897-$ 1948. Toronto, Lester \& Orpen Dennys Limited, 1989.

. The Worldly Years: The Life of Lester Pearson, Volume II: 1949-1972.

Toronto, Vintage Books, 1992.

English, John A. Failure in High Command; the Canadian Army and the Normandy Campaign. Ottawa, Golden Dog Press, 1995.

Feaver, Peter D. "The Civil-Military Problematique: Huntington, Janowitz, and the Question of Civilian Control." Armed Forces \& Society, Vol 23, Winter 1996, 149-178.

Foulkes, Charles. "Our Defence Dollars are Being Wasted", The Star Weekly Magazine, 14 October 1961.

Fraser, B. “Was Guy Simonds Really Sacked?” Maclean's, 23 July 1955, 21-22.

Freedman, Lawrence. The Evolution of Nuclear Strategy. London, Macmillan, 1985.

Fritzsche, Peter. A Nation of Fliers: German Aviation and the Popular Imagination. Cambridge, Harvard University Press, 1992.

3,26-27. . ““Air Conditioning' Germany.” Military History Quarterly, Vol 8, No.

Futrell, Frank. Ideas, Concepts, Doctrine: A History of Basic Thinking in the United States Air Force, 1907-1964. Maxwell AFB, Alabama, Air University Press, 1965.

Garsia, Clive. Planning the War. Harmondsworth, Middlesex, Penguin, 1941.

Gellner, John. "The Defence of Canada: Requirements, Capabilities and the National Will", Behind the Headlines, Vol. XVII, no. 3. Toronto, Canadian Institute of International Affairs, 1958.

. "Problems of Canadian Defence", Behind the Headlines, Vol XVII, no.

5. Toronto, Canadian Institute of International Affairs, 1958.

. "Some Thoughts on the Relationship of National Policies and Armed Forces," RCAF Staff College Journal, 1959, 53-58. 
Gibson, Colin. Air Power in Canada. An address by Colonel the Hon. Colin Gibson, M.C., M.A., Minister of National Defence for Air, to the Empire Club of Toronto, February 28, 1946. n.p., n.d.

Gibson, J. Douglas, ed. Canada's Economy in a Changing World. Toronto, Macmillan, 1948.

Gilbert, Martin. Winston S. Churchill: Volume VII, Road to Victory, 1941-1945. Boston, Houghton Mifflin, 1986.

Gilman, Ernest and Herold, Detlef E., eds. Democratic and Civil Control Over Military Forces (Monograph Series, No. 3). Rome, NATO Defense College, 1995.

Gole, Henry G. The Road to Rainbow: Army Planning for Global War, 1934-1940. Annapolis, Maryland, Naval Institute Press, 2003.

Gower, Dave. "A Note on Canadian Unemployment Since 1921", Perspectives on Labour and Income, Autumn 1992 (Vol 4, No. 3, Article 3), 1-7.

Granatstein, J.L. and Hitsman, J.M. Broken Promises - The History of Conscription in Canada. Toronto, Oxford University Press, 1977.

Graham, Howard. Citizen and Soldier: The Memoirs of Lieutenant-General Howard Graham. Toronto, McClelland \& Stewart, 1987.

Gray, Collin. Canadian Defence Priorities: A Question of Relevance. Toronto, Clarke Irwin, 1972.

Gray, Collin S. Nuclear Strategy and Strategic Planning. Philadelphia, Foreign Policy Research Institute, 1984.

Greenhous, Brereton et al. The Crucible of War, 1939-1945: The Official History of the Royal Canadian Air Force, Volume III . Toronto, University of Toronto Press, 1994.

Haglund, David and Sokolsky, Joel, eds. The US-Canadian Security Relationship: The Politics, Strategy, and Technology of Defence. Boulder, Westview Press, 1989.

Harris, Stephen. "Or There Would be Chaos: The Legacy of Sam Hughes and Military Planning in Canada, 1919-1939". Military Affairs, Vol 46, No. 3 (Oct 1982), pp. 120126.

. Canadian Brass - The Making of a Professional Army, 1860-1939. Toronto, University of Toronto Press, 1988.

Hatch, F.J. Aerodrome of Democracy. Ottawa, Directorate of History, DND, 1983. 
Haydon, Peter T. The 1962 Cuban Missile Crisis: Canadian Involvement Reconsidered. Toronto, Canadian Institute of Strategic Studies, 1993.

Hellyer, Paul. Damn the Torpedoes: My Fight to Unify Canada's Armed Forces. Toronto, McClelland \& Stewart Inc., 1990.

Hillmer, Norman et al, eds. A Country of Limitations: Canada and the World in 1939. N.p., Canadian Committee for the History of the Second World War, 1996.

Holmes, John W. "Canada in Search of Its Role." Foreign Affairs, Vol 41, July 1963, 659-672.

Horn, Lieutenant-Colonel Bernd and Stephen Harris, eds. Warrior Chiefs: Perspectives on Senior Canadian Military Leadership. Toronto, Dundurn Press, 2001.

http://csel.eng.ohio-state.edu/voshell/gforce.pdf

http://history.nasa.gov/sputnik/

http://www.globalsecurity.org/wmd/systems/b-50.htm

http://www.lswilson.ca/dewline.htm

http://www.nato.int/docu/comm/49-95/c490917a.htm.

http:/www.nato.int/archives/1st5years/annexes/a5.htm

Hunt, Barry and Haycock, Ronald, eds. Canada's Defence Perspectives on Policy in the Twentieth Century. Toronto, Copp Clark Pittman, 1993.

Huntington, Samuel P. The Soldier and the State: The Theory and Politics of CivilMilitary Relations. Cambridge, The Belknap Press of Harvard University Press, 1957.

Irvine, Dallas D. "The Origin of Capital Staffs." The Journal of Modern History, Vol X, No. 2, June 1938, pp. 101-178.

Isinger, Russell. The Avro Canada CF-105 Arrow Programme: Decision and Determinants. An unpublished MA thesis in Political Studies, University of Saskatchewan, 1997.

Jackson, J.L. “Air Power and Future Wars.” RCAF Staff College Journal, 1957, 29-35.

Janowitz, Morris. The Professional Soldier: A Social and Political Portrait. New York, The Free Press, 1964. 
. ed. The New Military - Changing Patterns of Organization. New

York: Russell Sage Foundation, 1964.

Jockel, Joseph. No Boundaries Upstairs: Canada, the United States and the Origins of North American Air Defence, 1945-1958. Vancouver, University of British Columbia Press, 1987.

. Canada in NORAD, 1957-2007: A History. Montreal, McGill-

Queen's University Press, 2007.

Johnston, William. A War of Patrols: Canadian Army Operations in Korea. Vancouver, University of British Columbia Press, 2003.

Keating, Tom and Larry Pratt. Canada, NATO and the Bomb - The Western Alliance in Crisis, Edmonton:. Hurtig Publishers, 1988.

Keyston, Dr. J.E. "Military Defence - The Nucleaus of the Problem." Canadian Army Journal, Vol 14, No. 2, Spring 1960, $2-7$.

King, Mackenzie, The Hon. W.L. "Defence Cooperation With the United States." Canadian Army Journal, Vol 1, No. 4, July 1947, 10-11.

Kotz, Nick. Wild Blue Yonder: Money, Politics, and the B-I Bomber. New York, Pantheon Books, 1988.

Larson, Arthur D. "Military Professionalism and Civil Control: A Comparative Analysis of Two Interpretations." Journal of Political and Military Sociology, Vol. 2 (Spring), $1974,57-72$.

LeMay, General Curtis E. and MacKinley Kantor. Mission with LeMay. Garden City, NY, Doubleday, 1965.

Lieff, Abraham Harold. Budget and Procurement Methods in the Royal Canadian Air Force. An unpublished MBA research Essay, University of Western Ontario, 1951.

Lindsey, G.R. "Defence Against Ballistic Missiles.” RCAF Staff College Journal, 1960, 41-49.

Lower, A.R.M. "Canada in the New Non-British World." International Journal, Vol 3, No. 3, Summer 1948, 208-221.

Mackenzie, S.P. "On Target: The Air Ministry, RAF Bomber Command and Feature Film Propaganda, 1941-1942." War \& Society, Vol 15, No. 2, October 1997, 43-60.

March, William and Robert Thompson, eds. The Evolution of Air Power in Canada: 1916 to the Present Day, Volume 2. N.p., Department of National Defence, 1997. 
Markides, Constantinos. All the Right Moves: A Guide to Crafting Breakthrough Strategy. Boston, Harvard Business School Press, 1999.

Martin, Laurence, ed. Strategic Thought in the Nuclear Age. Baltimore, John Hopkins University Press, 1981.

Martin, Michel Louis and Ellen Stern McCrate, eds. The Military, Militarism and the Polity - Essays in Honor of Morris Janowitz. New York, Free Press, 1984.

Massey, Hector J., ed. The Canadian Military - A Profile. Canada, The Copp Clark Publishing Company, 1972.

Matloff, Maurice and Edwin M. Snell. Strategic Planning for Coalition Warfare, 19411942, United States Army in World War II: The War Department. Washington, Office of the Chief of Military History, Department of the Army, 1953.

Matthews, Lloyd J., ed. The Future of the Army Profession. Boston:, McGraw-Hill, 2002.

McInnis, Edgar. "Canadian Opinion and Foreign Policy." Queen's Quarterly, Vol 62, No. 4, Winter, 1955-56, 503-514.

McLin, Jon B. Canada's Changing Defense Policy, 1957-1963: The Problems of a Middle Power in Alliance. Baltimore, MD, Johns Hopkins Press, 1967.

Mead, Gary. The Good Soldier: The Biography of Douglas Haig. London, Atlantic Books, 1007.

Meisel, John. "Guns and Butter: Foreign Affairs in Canada's Twenty-Third Parliament." International Journal, Vol 13, No. 3, Summer, 1957-58, 184-203.

Mets, David R. Master of Airpower - General Carl A Spaatz. Novato, California, Presidio Press, 1997.

Middlemiss, D.W. and Sokolsky, J.J. Canadian Defence: Decisions and Determinants. Toronto, Harcourt Brace Jovanovich, 1989.

Milberry, Larry. The Avro CF-100. Toronto, CANAV Books, 1981.

CANAV Books, 1984. , ed. Sixty Years: The RCAF and CF Air Command, 1924-1984. Toronto,

Miller, Edward S. War Plan Orange: The U.S. Strategy to Defeat Japan, 1897-1945, Annapolis, Maryland, Naval Institute Press, 1991. 
Millett, Allan and Williamson Murray, eds. Military Effectiveness, Volume 1: The First World War. Boston, Unwin Hyman, 1990.

Mintzberg, Henry. The Rise and Fall of Strategic Planning: Reconceiving Roles for Planning, Plans, Planners. New York, Free Press, 1994.

. Strategy Safari: A guided tour through the wilds of strategic

$\overline{\text { management. }}$ New York, Free Press, 1998.

Morton, Desmond. Ministers and Generals: Politics and the Canadian Militia, 1868 1904, Toronto, University of Toronto Press, 1970.

- A Peculiar Kind of Politics: Canada's Overseas Ministry in the First World War. Toronto, University of Toronto Press, 1982.

Moody, Walton S. Building a Strategic Air Force. Air Force History and Museum Program, 1995.

Nicks, Don, John Bradley and Chris Charland. Air Defence of Canada, 1948-1997, Ottawa, Gilmore Printing, 1997.

Nordeen, Lon O., Jr. Air Warfare in the Missile Age. Washington, DC, Smithsonian Institution Press, 1985.

Overy, Richard. Why the Allies Won. New York, W.W. Norton \& Company, 1996.

Pearson, Rt. Hon. L. B. "Canada Looks Down North." Foreign Affairs, Vol 24, No. 4, July 1946, 628-637.

27, No. 3, April 1949, 369-378

"Canada and the North Atlantic Alliance." Foreign Affairs, Vol . "Canada's Northern Horizon." Foreign Affairs, Vol 31, No. 4,

July 1953, 581-591.

Pickersgill, J.W. My Years with Louis St. Laurent - A Political Memoir. Toronto, University of Toronto Press, 1973.

Preston, Adrian. "The Profession of Arms in Postwar Canada, 1945-1970", World Politics, Vol XXIII, No. 2, January 1971, 189-214.

. "Canada and the Higher Direction of the Second World War, 1939-1945", Journal of the Royal United Service Institute, Vol CX, No. 637, February $1965,28-44$. 
Preston, Richard A. "The Discussion and Formulation of National Security Policy." RCAF Staff College Journal, 1959, 74-83.

Reynolds, David. Britannia Overruled - British Policy and World Power in the $20^{\text {th }}$ Century. New York, Longman, 1991.

Richter, Andrew. Security Cooperation and the Canada-U.S. Air Defence Relationship. An unpublished research essay towards a MA in International Affairs, The Norman Paterson School of International Affairs, Carleton University, 1990.

. The Evolution of Strategic Thinking at the Canadian Department of National Defence, 1950-1960. York Centre for International and Strategic Studies Occasional Paper Number 38, Canadian Defence and International Security Policy Special Issue Number 2. North York, Centre for International and Strategic Studies, York University, 1996.

. Avoiding Armageddon: Canadian Military Strategy and Nuclear

Weapons, 1950-63. Vancouver, UBC Press, 2002.

Roberts, Leslie. There Shall Be Wings: A History of the Royal Canadian Air Force. Toronto, Clarke, Irwin \& Company, 1959.

Roman, Peter J. "Strategic Bombers over the Missile Horizon, 1957-1963." Journal of Strategic Studies 18 (March 1995), 198-236.

Ross, Steven T. American War Plans, 1941-1945. London, Frank Cass, 1997.

Rosenthal, Michael. The Character Factory: Baden-Powell's Boy Scouts and the Imperative of Empire. New York, Pantheon Books, 1988.

Rowbottam, L.T. and Dodson, W.R. Project 2010: A Flight Plan for the Future. Ottawa, Department of National Defence, 1985.

Schaffell, Kenneth. The Emerging Shield: The Air Force and the Evolution of Continental Air Defense, 1945-1960. Washington, D.C., Office of the Air Force History, 1991.

Shaver, David E. Justifying the Army. Carlisle Barracks, Pennsylvania, US Army War College, 1990.

Sherry, Michael S. The Rise of American Air Power: The Creation of Armageddon. New Haven, Yale University Press, 1987.

Shields, William R. and Dace Sefers. Canadian Forces Command and Staff College: A History 1797 - 1946. Toronto, Canadian Forces Staff College, 1987. 
Simmonds, G. "Where We've Gone Wrong on Defence." Maclean's, 23 June 1956.

Smith, Edward A. Complexity, Networking and Effects-Based Approaches to Operations. Washington, Command and Control Research Program, 2006.

Smith, Perry McCoy. Creating Strategic Vision: Long-Range Planning for National Security. Washington, D.C., National Defense University Press, 1987.

Stacey, C.P. Arms, Men and Government: The War Policies of Canada, 1939-1945. Ottawa, Queen's Printer, 1970.

Press, 1984.

. Canada and the Age of Conflict, Volume 2. Toronto, University of Toronto

Stewart, Craig. "Canada and the Development of the Aircraft Jet Engine." Canadian Defence Quarterly, Vol 9, No 1, Summer 1979, 48-56.

. Shutting Down the National Dream: A.V. Roe and the Tragedy of the Avro Arrow. Toronto, McGraw-Hill Ryerson Ltd, 1988.

. The Life and Times of Crawford Gordon and the Avro Arrow: An Arrow Through the Heart. Toronto, McGraw-Hill Ryerson Ltd, 1998.

Swanson, R.F. An Analytical Study of the United States/Canadian Defence Relationship as a Problem of Structure, Response and Process: Problems and Potentialities. An unpublished PhD thesis, The American University, Washington, D.C., 1969.

Swettenham, John. McNaughton, 1944-1966, Volume III. Toronto, The Ryerson Press, 1969.

Thillaye, Bernard C. Politco-strategic Forecasting: A Survey of Some Methods in Current Use. Kingston, National Defence College, 1972.

Thompson, R.W. "Canada, A United Europe and NATO." International Journal, Vol 12, No. 3, Summer, 1957, 220-226.

Tremblay, Yves. Ed. Canadian Military History Since the $17^{\text {th }}$ Century: Proceedings of the Canadian Military History Conference, Ottawa, 5-9 May 2000. Ottawa, Directorate of History and Heritage, 2000.

van Crevald, Martin. The Transformation of War. New York, The Free Press, 1991.

The Free Press, 1991.

Technology and War: From 2000 B.C. to the Present. New York, 
(Spring 1996), 76-81.

. "The Rise and Fall of Air Power." Military History Quarterly 8

Vano, Gerard S. Canada: The Strategic and Military Pawn. New York, Praeger Publishers, 1988.

Von Clauswitz, Carl. On War . Translated by Michael Howard. Ewing, New Jersey, Princeton University Press, 1989.

Wakelam, Randall. Flights of Fancy: RCAF Fighter Procurement 1945-1954. An unpublished MA thesis in War Studies, Royal Military College of Canada, Kingston, 1997.

. The RCAF Staff College, 1943-1965: Educating for Military

Effectiveness. An unpublished research essay, Canadian Forces Command and Staff College, Toronto, 2003.

Warden, John A. The Air Campaign: Planning for Combat. Washington, D.C., National Defense University Press, 1988.

Weigley, Russell Frank. The American Way of War - A History of United States Military Strategy and Policy. Bloomington, Indiana University Press, 1977.

Whitaker, Reg and Marcuse, Gary. Cold War Canada: The Making of a National Insecurity State, 1945-1957. Toronto, University of Toronto Press, 1994.

Willett,T.C. Canada's Militia: A Heritage at Risk. Toronto, Conference of Defence Associations Institute, 1990.

Wolk, Herman S. The Struggle for Air Force Independence, 1943 to 1947. Washington, D.C., Air Force History and Museums Program, 1997.

Wood, Derek. Project Cancelled: British Aircraft That Never Flew. New York, The Bobbs-Merrill Company, Inc., 1975.

Wood, H.F. Strange Battleground: The Operations in Korea and Their Effects on the Defence Policy of Canada. Ottawa, Queen's Printer, 1966.

Worden, Mike, Colonel, USAF. Rise of the Fighter Generals - The Problems of Air Force Leadership, 1945-1982. Maxwell Air Force Base, Alabama, Air University Press, 1998.

Ziegler, Mary. The Story of the Women's Division Royal Canadian Air Force. Hamilton: RCAF (W.D.) Association, 1973. 
Zimmerman, David. The Great Naval Battle of Ottawa. Toronto, University of Toronto Press, 1989. 